\title{
Sandyland Farmers: Life in the Countryside Before Camp Swift, 1920-1942
}

Thad Sitton

Center for Archaeological Studies

Follow this and additional works at: https://scholarworks.sfasu.edu/ita

Part of the American Material Culture Commons, Archaeological Anthropology Commons, Environmental Studies Commons, Other American Studies Commons, Other Arts and Humanities Commons, Other History of Art, Architecture, and Archaeology Commons, and the United States History Commons

Tell us how this article helped you.

This Article is brought to you for free and open access by the Center for Regional Heritage Research at SFA ScholarWorks. It has been accepted for inclusion in Index of Texas Archaeology: Open Access Gray Literature from the Lone Star State by an authorized editor of SFA ScholarWorks. For more information, please contact cdsscholarworks@sfasu.edu. 
Sandyland Farmers: Life in the Countryside Before Camp Swift, 1920-1942

Creative Commons License

(c) $($ ) $(9)$

This work is licensed under a Creative Commons Attribution-NonCommercial 4.0 International License 


\section{Sandyland Farmers:}

Life in the Countryside Before Camp Swift, 1920-1942
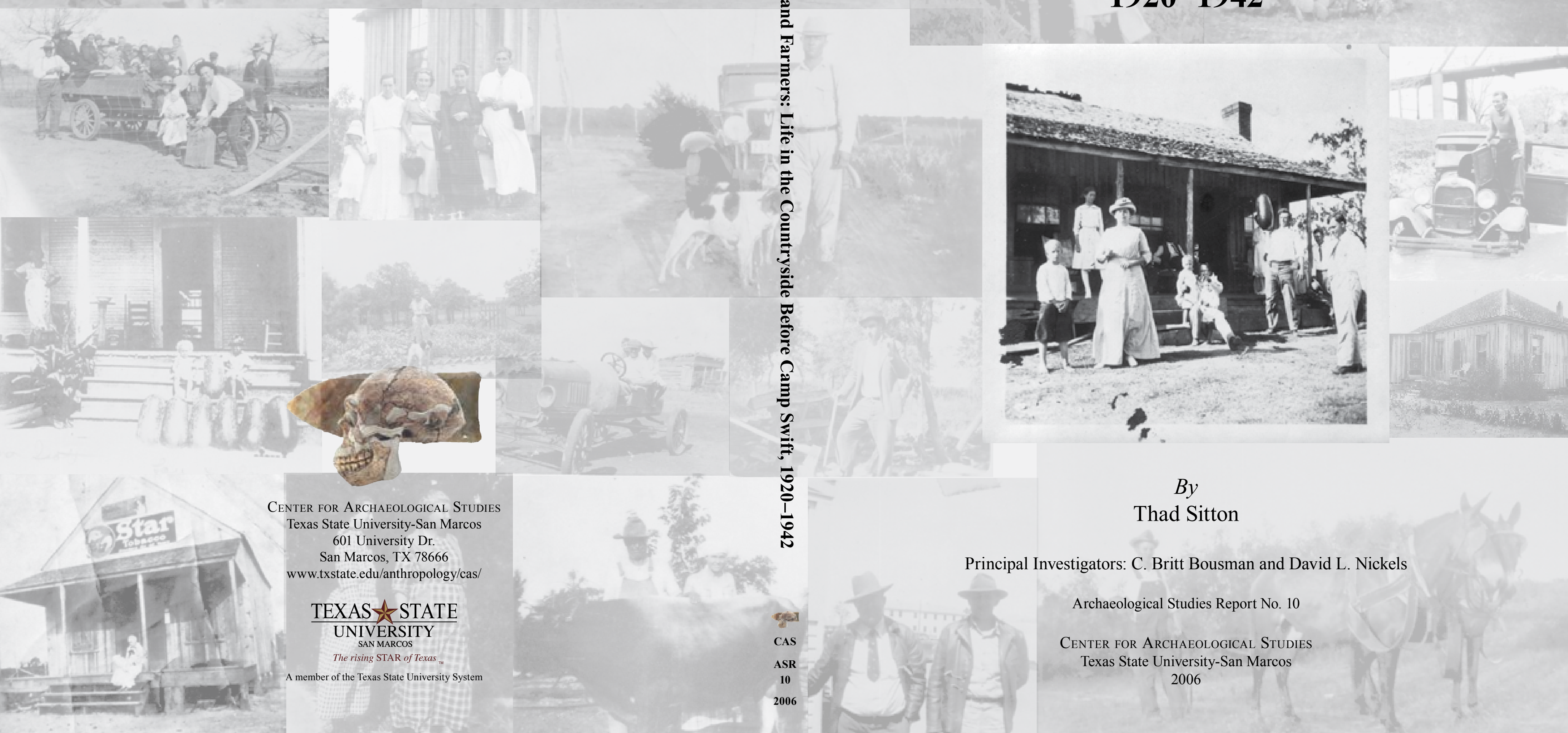

$$
\text { By }
$$

Thad Sitton

Principal Investigators: C. Britt Bousman and David L. Nickels

Archaeological Studies Report No. 10

$$
2006
$$




\section{Sandyland Farmers:}

\section{Life in the Countryside Before Camp Swift, 1920-1942}

by

Thad Sitton

Principal Investigators:

C. Britt Bousman and David L. Nickels

Archaeological Studies Report No. 10

Center for Archaeological Studies

Texas State University-San Marcos 2006 
The following information is provided in accordance with the General Rules of Practice and Procedures, Title 13, Chapter 26, Texas Administrative Code:

1. Type of investigation: Oral history popular report.

2. Project name: Camp Swift Oral History Project, Popular Report

3. County: Bastrop

4. Principal Investigators: C. Britt Bousman and David L. Nickels

5. Name and location of sponsoring agency: The Adjutant General's Department of Texas, Directorate of Facilities and Engineering, Environmental Branch, Austin, Texas.

6. Published by the Center for Archaeological Studies, Texas State University-San Marcos, 601 University Drive, San Marcos, Texas, 78666-4616 (2006)

Texas State University-San Marcos is a member of the Texas State University System Copyright (C) 2006 by the Center for Archaeological Studies at Texas State University-San Marcos

$$
\text { All rights reserved. }
$$

No part of this book may be reproduced or utilized in any form or by any means, electronic or mechanical, including photocopying, recording,

or by any information storage and retrieval system without permission in writing.

For further information on this and other publications by the Center for Archaeological Studies, please contact:

Center for Archaeological Studies

Texas State University-San Marcos 601 University Drive

San Marcos, TX 78666-4616

www.txstate.edu/anthropology/cas/

Editor: Maggie Moore

Cover Photograph: Polly Owen of Oak Hill (left foreground) and other members of the Owen family in front of T. W. Owen's house across the road from Oak Hill Cemetery ca. 1914 (Fay Owen Pannell). T. W. Owen is with his grandsons in center, seated, and Polly's husband Edgar is at the far right.

Printed in the United States of America

by

Ginny’s Printing Inc., Austin 
Dedicated to former residents of the Camp Swift lands, and to the Oak Hill Cemetery Association and the Sayersville Historical Society, who keep the faith. 


\section{Table of Contents}

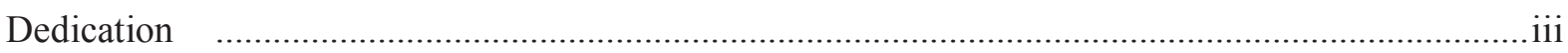

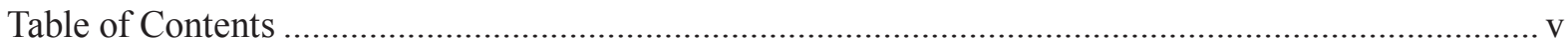

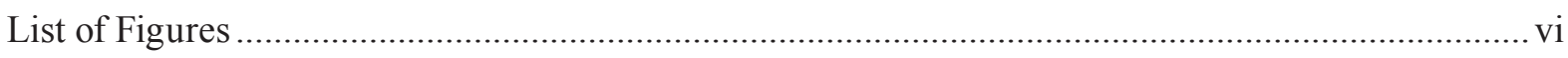

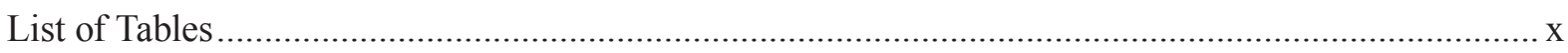

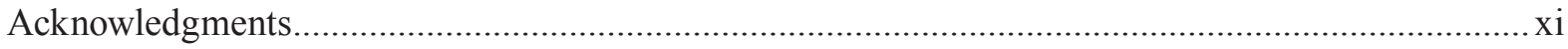

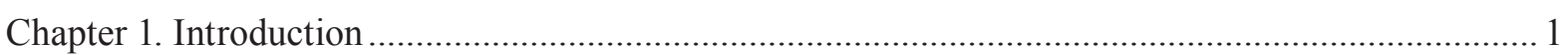

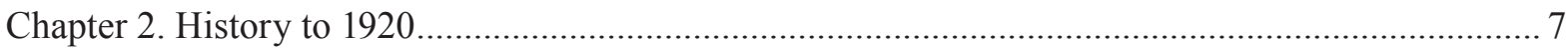

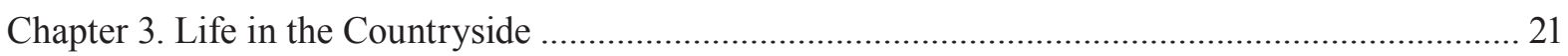

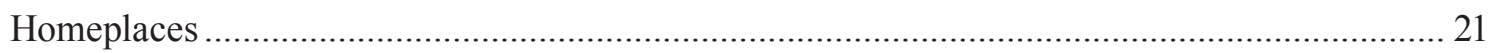

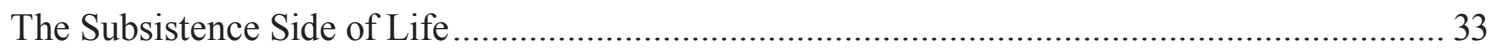

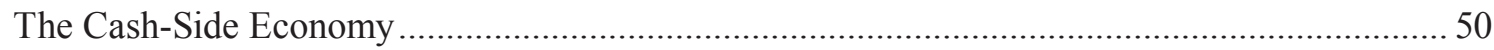

Owen Chronicles Economic Disaster - Community and the 1925 Drought .................................. 61

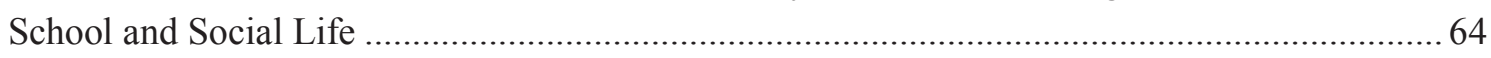

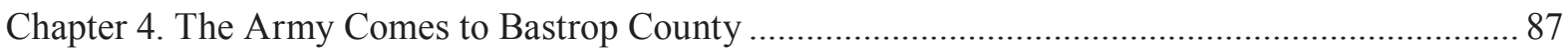

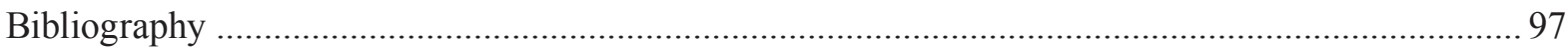




\section{List of Figures}

1-1. Centers of the rural communities existing prior to 1942 that are located in or near the present-day Camp Swift area.

1-2. Joe Owen of Oak Hill in his stripped-down Model T Ford with Ezra and Jesse Shelton, late $1920 \mathrm{~s}$

2-1. 1830 Map of Stephen F. Austin’s "Little Colony" showing Mina, which was later renamed Bastrop (map courtesy of the Texas General Land Office).

2-2. Grover Scott's family at the Abner Scott home ca. 1940 13

2-3. Andrew Owen standing above his grandfather, T. W. Owen, who is holding Thurston and Hollis Stagner in front of an original log house at Oak Hill

2-4. Early Oak Hill board-and-batten frame house. Resident Ruth Allen Hancock and her 5 children in front of the family home, date unknown.

2-5. Wayside School ca. 1927-1928

2-6. Oak Hill School, 1929 18

2-7. Sayers Store, date unknown. 18

3-1. Joe Owen's family home in Oak Hill, 1935-1940 21

3-2. The DeGlandon House, 1930. 22

3-3. Louise Smith Goerlitz's parents and aunt at the old Harvey Smith farm (Ransom Place), 1920. 22

3-4. Harvey Smith's house at Oak Hill, late 1930s

3-5. Floor plan of Arthur Hancock's house in Oak Hill 23

3-6. JoNell Hancock's mother (Vivian Buffa Hancock) and grandmother (Ida Scarborough Buffa), date unknown.....

3-7. Floorplan of the John Ransom House at Oak Hill.

3-8. John Ransom House at Oak Hill, date unknown 25

3-9. Diagram based on a sketch map drawn from memory by Jesse Lee Scott (Abner C. Scott's sister) of the original log cabin built by Abner Scott (Abner C. Scott's greatgrandfather) around 1850, plus subsequent frame additions

3-10. Robert W. Smith, Bertie Hancock Smith, and their six children, 1929-1930 27 


\section{List Of Figures (Continued)}

3-11. Billy, Jimmy, and Jerry Fleming with horses, late 1930s

3-12. Plan of the Arthur Hancock homeplace showing the large garden and various patches............. 34

3-13. Sue Smith and her mother Edith Mae Smith by a lemon tree, date unknown ............................ 35

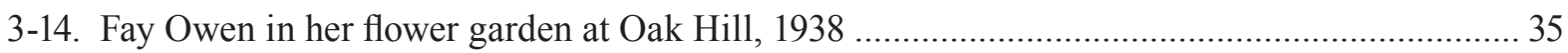

3-15. Andrew Morgan Smith and daughter Sue poise with prize bull Westgate................................. 39

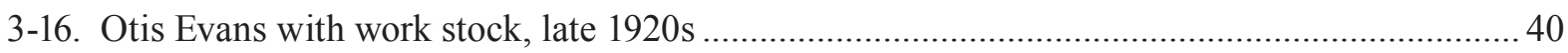

3-17. Smokehouse at the rear of the Hancock house in Oak Hill, date unknown ............................... 44

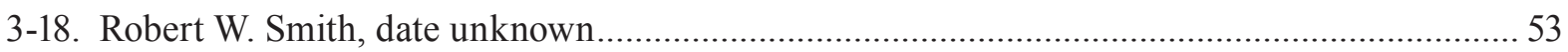

3-19. Abner Scott's grandmother Minnie Lea Scott and Abner's sisters Mary Lou and Jesse Lee Scott showing off watermelons, ca. 1932 ...................................................................... 54

3-20. T. W. and brother Bill Owen eating watermelon at T. W.'s home across the road

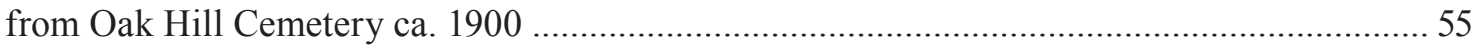

3-21. Grace DeGlandon Smith (Louise Smith's mother) and her turkeys .......................................... 56

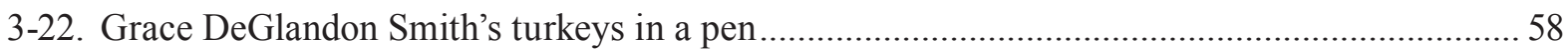

3-23. Joe Owen, manager of the Sayers Store, stands at back of the store ca. 1915 ............................ 59

3-24. Graded tipple leading from Frank Dennison's slope mine, operated from 1914 to 1924 ........... 60

3-25. Mexican laborers in front of the Sayers Coal Mine, date unknown ............................................ 60

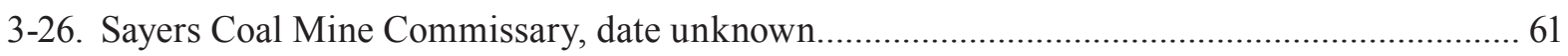

3-27. Polly Owen of Oak Hill (left foreground) and other members of the Owen family in front of T. W. Owen's house across the road from Oak Hill Cemetery ca. 1914 .......................... 61

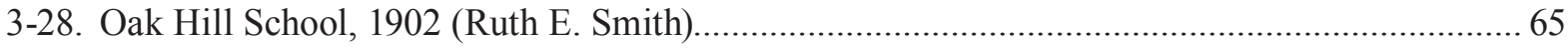

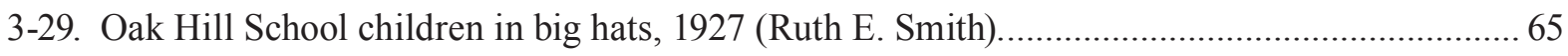

3-30. 1929 photograph of Oak Hill School students, showing several of the Camp Swift

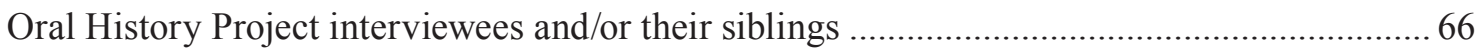

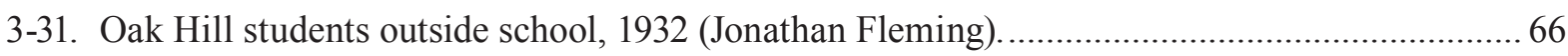

3-32. Schoolteacher Mayme McCright at Wayside School, sitting on the cistern, 1927-1928_........... 67 


\section{List OF Figures (Continued)}

3-33. Oleta Scott and Mayme McCright at Wayside School, date unknown 67

3-34. Mr. Powell, schoolteacher at Oak Hill School, cutting wood at the woodpile, 1930s 68

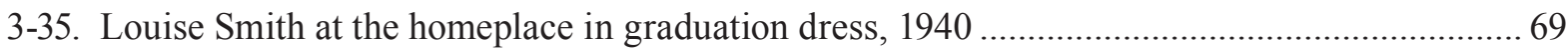

3-36. Lizzie Stagner DeGlandon and Alcide DeGlandon at Oak Hill house, 1927 69

3-37. Mr. Powell (second from right) instructs the carpentry class at Oak Hill School, 1930s........... 70

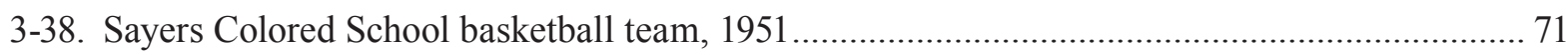

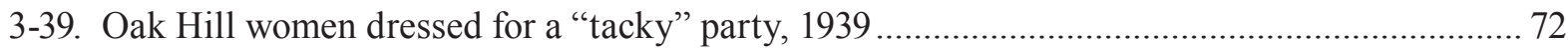

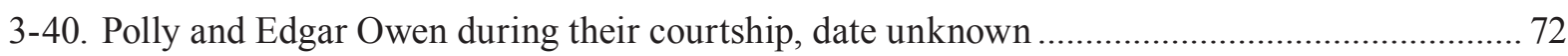

3-41. Jepp Hill Miller with violin, date unknown ............................................................................... 74

3-42. Perry Mills, a CCC camp boy, and his Model A Ford stuck at an old wagon crossing

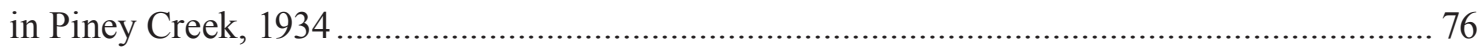

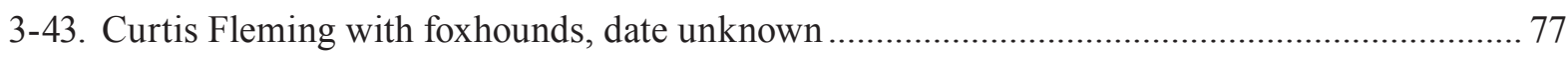

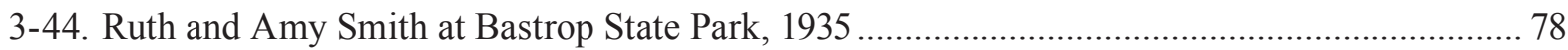

3-45. Andrew Morgan Smith family ready to leave on a picnic to the Colorado River ....................... 79

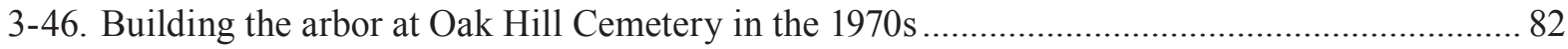

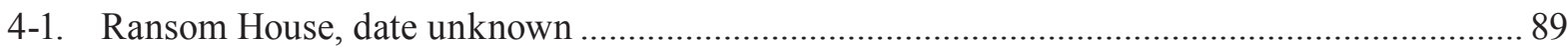

4-2. Harvey Smith and Harry Kunkle working at Camp Swift during the early 1940s .................... 89

4-3. Fay Owen Pannell's daughter Peggy at the door of the house that Joe and Elgitha Owen moved into after the takeover, 1943 90

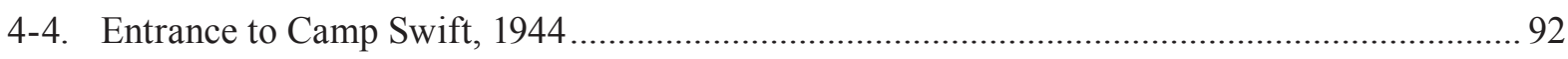

4-5. Harvey Smith family visits their old homeplace on Camp Swift, 1945 ...................................... 93

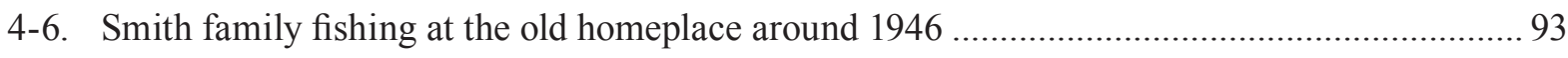

4-7. Fay Owen Pannell visiting the ruins of a house site on Dogwood Creek near Oak Hill Road on Camp Swift, 1970s 94 


\section{List OF TABLES}

2-1. Community affiliations of the Camp Swift Oral History Project interviewees ......................... 17 


\section{ACKNOWLEDGMents}

This publication would not have been possible without the assistance of nineteen persons we interviewed about life in the countryside before Camp Swift. Individuals recording their memories for the Camp Swift Oral History Project were Gertrude Dunkin Barton, Mary Lou Reese Benford, Leola Blackwell Carman, Jonathan Curtis Fleming, Dean Fort, O L Flowers, Erhard Goerlitz, Louise Smith Goerlitz, Ruby Mae Thomas Johnson, Morris J. Kastner, JoNell Hancock Majors, May Belle Miller Morriss, Fay Owen Pannell, Abner C. Scott, S. J. "Jack" Scott, Ruth E. Smith, Walter B. Thomas, Irene Fleming Watson, and Evelyn Cottle Wilson. With one exception, interviews of these contributors appear in their entirety in another project publication.

Other people, living and deceased, made special contributions to Sandyland Farmers. Bettye Lynn Blackwell Light graciously allowed the use of her written memoir of life on an Oak Hill farm, and I quoted Bettye many times. Local historian Jonathan Fleming offered many insights. Abner Scott and Fay Pannell answered my historical questions over the telephone and racked their brains thinking of other persons to interview. The Sayersville Historical Bulletin, an occasional publication (through twelve issues) of the remarkable Sayersville Historical Society, provided valuable interview data from persons now deceased, as well as useful scholarly articles that shed light on the Camp Swift lands. Finally, thirty years of Polly Owen's weekly "Oak Hill" column in the Bastrop Advertiser greatly educated me about the ebb and flow of life at Oak Hill, Camp Swift's main precursor community.

Martha Doty Freeman and Dave Nickels shared with me the interviewing duties and made equal contributions to the data underlying Sandyland Farmers, though all historical interpretations are my own. Thanks to the Center for American History, The University of Texas at Austin, for agreeing to serve as permanent historical repository for project tapes, transcripts, and photographs. Thanks to the staff of the Center for Archaeological Studies, Texas State University-San Marcos, for the hard work of taking this manuscript to publication. Dr. C. Britt Bousman adivsed and oversaw the publication process, Carole Leezer provided logistical and administrative support, and Maggie Moore edited and assembled the publication. Thanks emphatically to Shelly Sullo, former Cultural Resource Manager for the Texas Army National Guard, Camp Mabry, who conceived and supported the Camp Swift Oral History Project and this publication. Also thanks to Kristen Wenzel, current Cultural Resource Manager for the Texas Arny National Guard for her continued support of the project and its associated publications, and Dawn Ramsey, who reviewed the inital draft.

Thad Sitton 


\section{Chapter 1}

\section{INTRODUCTION}

A few miles north of the county seat of Bastrop in Bastrop County, Texas, three highways form a rough triangle enclosing slightly more than 87 square miles of rural landscape. Highway 21, the modern counterpart of the Old San Antonio Road, El Camino Real, forms the southern boundary just north of Bastrop State Park. Highway 290, running roughly northwest from Paige to Elgin, composes the eastern boundary, and Highway 95 from Elgin south to Bastrop completes the triangle. ${ }^{1}$ On the eve of World War II, some 350 farming families lived within several dispersed rural communities that populated this stretch of sandyland countryside, dissected from north to south by the wandering drainages of Big Sandy, McLaughlin, Dogwood, Piney, and Alum creeks (Figure 1-1). ${ }^{2}$ These families were arranged into the communities of McDade, Wayside, Oak Hill, Spring Branch (Scott Falls), and Sayers. Little did the farm families know that by June 15, 1942, all would be off their lands to make way for the 55,982-acre Camp Swift, a major training facility of the United States Army.

Some of the things that attracted the United States Army to the area had made the place a "hard row to hoe" for several generations of Southern cotton farmers. Population was scattered and sparse across the well-drained, sandy soils that covered rolling, partly wooded, cedar and post oak uplands between the creeks. Floodplain forests of elm, hackberry, cottonwood, pecan, and hickory flourished in the creek bottoms, except where fields had been cleared. Additionally, land values were low. ${ }^{3}$ Travel cross-country was easy, and as generations passed, horsemen, wagons, and Model T Fords (Figure 1-2) had etched a web of sandy roads, public and private, into the land. ${ }^{4}$

Three-quarters of a century of cotton and corn crops had come and gone on some of this land, and the sandy loams - rarely if ever fertilized-were depleted. Cotton had been the mainstay cash crop of the pioneers and sons of the pioneers, but by 1940 it grew poorly. Farmers had turned to a "truck crop" agriculture that emphasized classic Southern sandyland subsistence crops produced (one hoped) in excess of what each family needed for their consumption, which allowed the surplus to be sold in town. Local truck crops included watermelons, cantaloupes, sweet potatoes, peanuts, field peas, and various garden vegetables.

Most farm families, landowners and renters alike, also kept a menagerie of domestic animals to complete the subsistence side of their farms - to aid in, as they said, "living on the place." Chickens, turkeys, guinea fowl, and geese foraged the countryside around area farms; they hustled for most of their own food but daily hand-outs of corn kept them in tenuous domestication. Although an occasional calf or yearling might be sold, cattle and hogs 


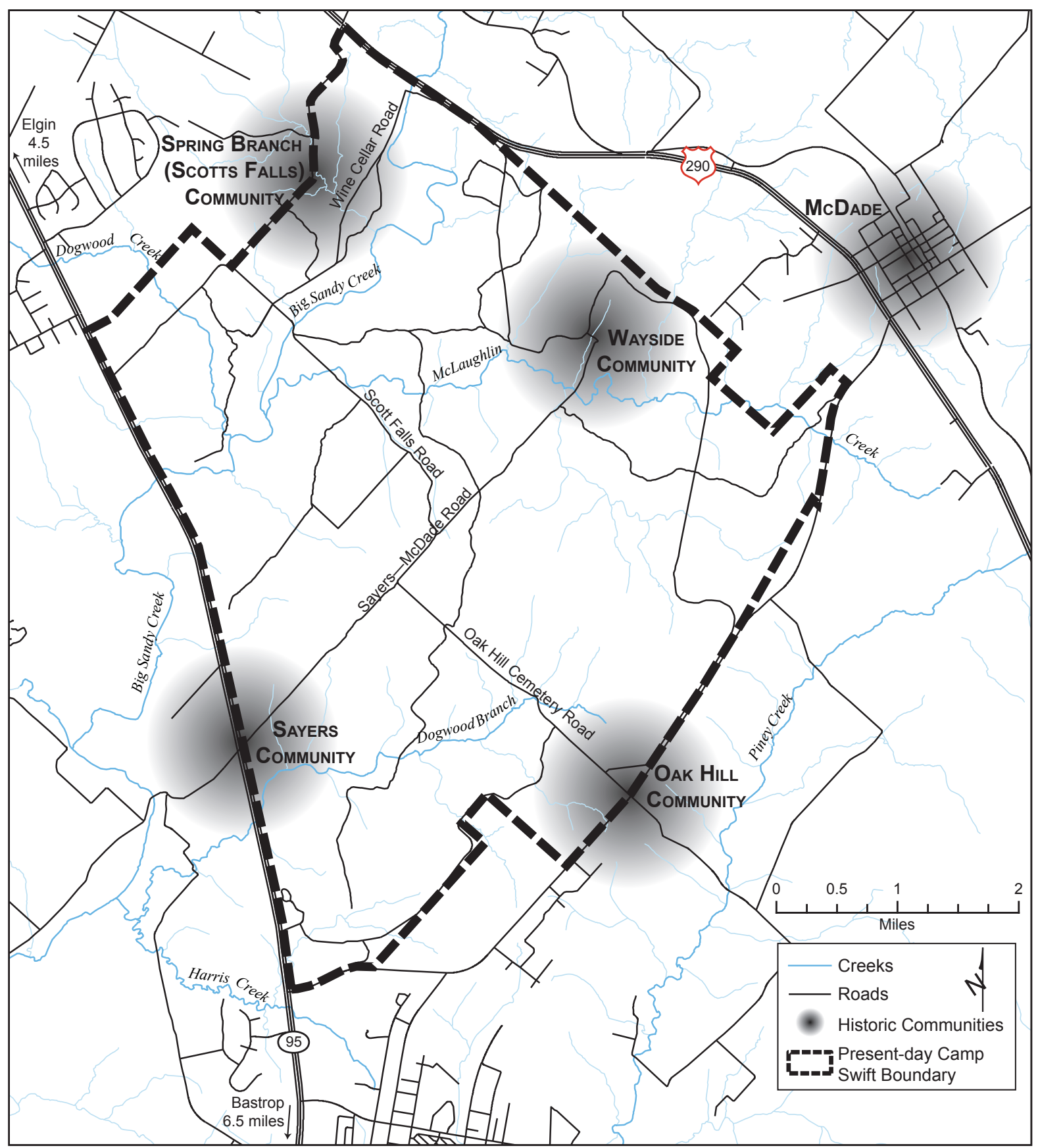

Figure 1-1. Centers of the rural communities existing prior to 1942 that are located in or near the present-day Camp Swift area.

usually were kept for home consumption - for dairy products and pork in the smokehouse. Besides being a subsistence mainstay, chickens produced eggs to exchange at the country store for flour, sugar, salt, coffee, kerosene, and tobacco, which were the few staples not produced on farms. Turkeys became a major money crop; ranging at large in the woods and pastures, they required little corn and largely fed themselves on grasshoppers, acorns, and pecans. Farmers found a ready market for free-range turkeys during the holiday seasons of Thanksgiving and Christmas. 
By 1940, the heyday of cotton had come and gone on the northern Bastrop County sandylands, although major cotton agriculture still flourished on the fertile Blackland Prairie just to the north. By necessity, most sandyland farm families rejected cotton farming for a more diversified economy. It was a hardscrabble existence, but people stubbornly persisted. Local historian Jonathan Fleming summed up the experience of his parents and grandparents with plain words: "It was just a hard life, bare to the bone, no money in your pocket. Really, nobody was, quote, 'farming and ranching.' Like I said, there was no money being made out here. They was just keeping on." ${ }^{5}$

Such comments could have described many other areas across the so-called "Cotton South" by 1940 , although historians rarely studied such places. As Jack Temple Kirby noted, before World War II there was not one agricultural South, but many: row-crop, black-belt areas where cotton still dominated; worn-out cotton areas retrograding toward subsistence farming; dairy product and livestock areas; and what Kirby termed "the self-sufficient South," where free-range livestock and growing one's living on the farm took precedence over growing cotton.

The "subsistence South" has rarely attracted the attention of historians, who perhaps have been overly preoccupied with cotton agriculture. The present study of life on the Bastrop sandylands before the war is thus both an exception to the general rule and something of an irony. The War Department took these 55,982 acres of sand hills and creek valleys in 1942 for a military training base in large measure because of the sparse population and low land value; however, because the land was taken (and because governmental inheritors of the land remain, principally the Texas Army

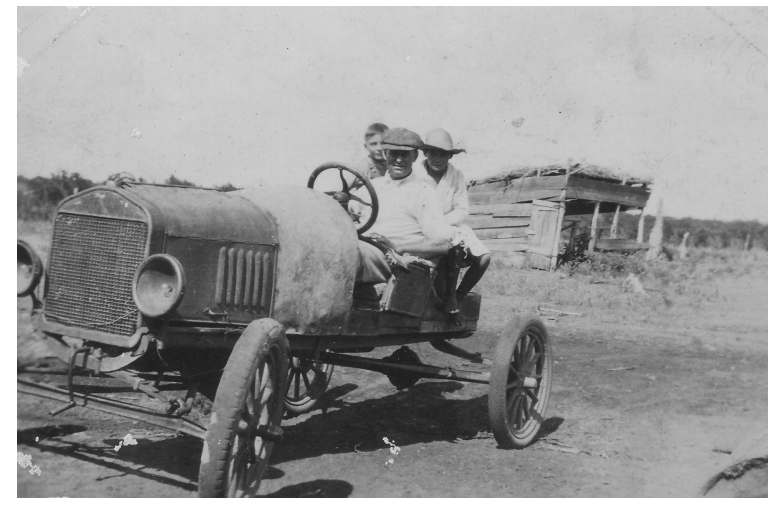

Figure 1-2. Joe Owen of Oak Hill in his strippeddown Model T Ford with Ezra and Jesse Shelton, late 1920s (Fay Owen Pannell).

National Guard), the obscure sandylands of Bastrop County became a subject of detailed archaeological and historical study.

However, long before the scholars arrived, the United States Army profoundly modified the setting. The former inhabitants of the land quickly left as the development of a huge military base began. Camp Swift, already training troops by early summer of 1942, incorporated 2,750 buildings and ultimately handled a maximum population of over 44,000 military personnel. The base had many miles of roads, its own 750-bed hospital, churches, a fire department, swimming pools, theaters, utilities, and (after a year) a German prisoner of war camp that housed around 4,000 men, most of whom had been captured in North Africa. As some of Camp Swift's historians observed, "In effect a new city of over forty thousand inhabitants was superimposed on Bastrop County, tripling the county's population and dwarfing the nearby town of Bastrop, which had a population of only 1,976 in 1940."”

The world of Bastrop County's sandyland farmers had been obliterated in a few weeks. The government compensated them only for their land. Houses and other property could 
be moved off the base - if the families could arrange to accomplish this, which most could not. ${ }^{8}$ After abandonment by its former owners, the agricultural countryside offered hazards to Army troops training to face the Germans, so authorities quickly altered it. The landscape was, as Jonathan Fleming put it, "wiped smooth — dams were broke, wells were filled, and the houses were bombed." 9

After the war, the government returned nearly half of Camp Swift's 55,982 acres to private hands, although not always to the original owners. ${ }^{10}$ Some families did not wish to go back to a hard life in the countryside. Some did not have enough money to repurchase their former land at the price the government had given them and then pay for new homes, barns, fences, stock ponds, and other things necessary to put the land back into production. ${ }^{11}$ Other families who wished to purchase back their lands never got the chance. Over half of the large World War II Camp Swift remained in governmental control by 2004 , held by the Texas Army National Guard, the Texas Parks and Wildlife Department (leasing from the Lower Colorado River Authority), and The University of Texas at Austin. The northern end of the triangle, some 11,500 acres operated by the Texas Army National Guard as a training facility, functioned in 2004 as the modern Camp Swift.

As mandated by federal law, the Texas Army National Guard has conducted intensive surveys of the cultural resources within its 11,500-acre Camp Swift. By 2003, researchers contracted by the Guard had documented 169 archaeological sites. Most of these were Native American sites several hundred to several thousand years old, but others were the sites of Anglo American farmsteads from before the war. ${ }^{12}$ After former owners' desperate attempts at property removal and the repeated passage of troops and tanks during the war years, often not much remained of these places. Archaeologists often term these remains "house scatter" - broken bricks from chimneys, glass and crockery fragments, and, as one historical archaeologist termed the gleanings of his patient trade, other "small things forgotten."13 Not much was left to show that generations of human lives had come and gone. What little was present, however, invited thoughtful consideration.

For example, at 41BP663, a small twentiethcentury historic site near Scott Falls Road, a shovel test excavation yielded few items, among them a single suspender button or snap from a pair of work overalls. "It has a heavily rusted ferrous facing with a cuprous backing," the archaeologist wrote in careful language. "Overalls were and still are very common farm work clothes. By the mid-1800s, they were the first mass-produced pieces of clothing."14

A "small thing forgotten," to be sure, spaded back into the light of day from dirt and oblivion, but the rusted overalls snap somehow strongly evoked the lost world of Bastrop County's sandyland farmers, which in 2004 might still be pursued in living memory. Oral historians also search for the small things forgotten, or at least unrecorded, and sometimes the former owners of these things talk for a long time. In 2004, the Texas Army National Guard, with the Center for Archaeological Studies, Texas State University-San Marcos, and the Center for American History, The University of Texas at Austin, launched an oral history project.

The Camp Swift Oral History Project focused not on the army training facility but 
on life in the countryside before its arrival in 1942. The project's information sheet summarized the objective:

The main goal of the project is to learn more about the families, communities, and lifeways of the people who lived on the land that is now occupied by Camp Swift. Topics of interest include, but are not limited to, life on the family farm, subsistence practices, the cash crop economy, settlements, life in town, and related issues. Interviewees will be encouraged to tell stories of their personal experiences. They also will be encouraged to share historic photographs that depict family members, family homes, and scenes of daily life.

Eighteen former residents of the north Bastrop County countryside, a rare and diminishing group by 2004, provided this information and much more. Life in the countryside before the war is a subject "about to go over the edge," as oral historians euphemistically say. Oral historians always arrive to do their job just in the nick of time, except when they come too late. People invariably say things like, "If you had only come when Uncle Jack was still alive." Martha Doty Freeman, David Nickels, and Thad Sitton were the interviewers. Two published products stem from our oral history research: complete verbatim transcripts of all interviews in one publication, and the informal history of life in the countryside that you now read.

As our historical informants all knew and all tried in one way or another to communicate, life on the mule-powered, kerosene-lit farms of the 1920s and 1930s was very different from life in 2006, when rural existence in so many ways mirrors life in town. Most 1930s farms lacked even telephones, and those that had them built and maintained their own lines. Water in those days came from the well, vegetables from the garden, eggs from the yard, and meat from the smokehouse. Everybody in the family, men, women, and children, worked very hard at the complicated round of labors and chores associated with the subsistence and cash-crop sides of the farm. Work days ran from first light to dark, "from can see to can't," the old saying goes. A few persons we interviewed waxed a little nostalgic about these labors, but most did not. When asked about his best memories of life in the countryside before the war, Morris J. Kastner thought for a while then responded, "Best? Well, the best memory I guess is when it got dark you went to bed, because you couldn't do nothing." 15

Another elderly farmer said that in those days "fifteen miles down the road was kind of like another land." ${ }^{\prime 6}$ Farm families knew the surrounding countryside well, but might go into the county seat of Bastrop only once or twice a year. They put on their shoes and best clothing and tried to look sophisticated when they did so, since city folks tended to look disparagingly at farmers from the backwoods. For young people in particular, the prospect of a trip to the unfamiliar courthouse town provoked both excitement and trepidation.

This report uses oral history to explore the lost countryside through the words and memories of former natives of the place. After a historical retrospective on Bastrop County in Chapter 2, I turn in Chapter 3 to a detailed consideration of life on the sandyland farms that predated Camp Swift, focusing on the years between 1920 and 1942. Not much changed during those decades, some said. After talking to many old-timers, Oak Hill community historian Jonathan Fleming told his interviewer, "I think the people out 
here was too damn poor to worry about a Depression."17

Throughout this exploration of everyday life on the farm based on the oral histories, which forms the body of Sandyland Farmers, I follow the social historian's basic insight, "There are no insignificant details"; there are no small things half forgotten, too unimportant to value and record. In any case, as another saying asserts, "God is in the details"; every historical fragment suggests a lost world. These recollections of the past come from only 87 square miles of Texas countryside but, as Charles Joyner once observed of his own research in South Carolina, "All history is local history, somewhere."18

\section{Endnotes}

1. Wharton 2000:173

2. Leffler 2001

3. Leffler 2001; Nickels et al. 2003

4. Skelton and Freeman 1979

5. Fleming 2004

6. Kirby 1990:45

7. Nightengale and Moncure 1996:16

8. Robinson 1998

9. Fleming 2004

10. Robinson 1998

11. Ibid.

12. Nickels et al. 2003

13. Deetz 1977

14. Nickels et al. 2005:57

15. Kastner 2004

16. Sitton and Utley $1997: 10$

17. Fleming 2004

18. Joyner 1984:xvi 


\section{Chapter 2}

\section{History to 1920}

Stephen F. Austin saw the area that became Bastrop County as he traveled the Old San Antonio Road on his first trip to Texas in 1821. The untouched wilderness seemed bountiful beyond expectations, a mixed landscape of woodland and prairie abounding in game, bee trees, and wild grapes. Herds of whitetail deer, mustangs, and wild cattle roamed the scattered prairies through which he passed, along with small groups of bison. Wild turkeys gobbled from the thickets. Scouts from Austin's party found it a simple task to shoot the 16 deer required for daily consumption. ${ }^{1}$ After crossing the Colorado at the old Spanish ford, Austin wrote in his journal on August 7, 1821:

Came to the Colorado River - poor gravelly ridges and near the river heavy pine timber, grapes in immense quantities on low vines, red, large and well flavored, good for Red wine. The Colorado River is sometimes less than the Brassos [Brazos], banks very high - generally clear of overflow-bottom and banks gravelly, water very clear, and well tasted, current brisk, the river very much resembles the Cumberland River, except that there are no rocks and it is some larger. The bottom where the road crosses is about five miles, mostly high prairie, clear of overflow, land rich, timber Pecan, Ash, Oak, Cedar, abundance of fish. ${ }^{2}$

Stephen F. Austin did not forget this ford on the Colorado, just west of an isolated range of pine hills known as "Lost Pines," but he chose to center his first colony at San Felipe on the Brazos, well to the southeast on the edge of the coastal plain. This location made it easier to get cotton to the Gulf of Mexico and New Orleans, but there was another reason. As Austin had learned from Spanish authorities, the area west and north of the pines remained "Indian country."

Throughout the eighteenth century, many different Native American groups had hunted, fought, and traded-mixed and merged - in the area of Lost Pines. Spanish records noted over fifty different groups, including such formidable fighters as the Apache, Kiowa, and Comanche. ${ }^{3}$ Hasinai Caddos came west to hunt the buffalo and trade pottery and corn to the Tonkawa for flint and hides. Comanches came east to hunt and raid other tribes and the Spanish. Delawares and other displaced eastern groups migrated in looking for refuge. The area was a rich mixing zone of landscapes and resources - wooded alluvial river valley (with important pecan groves), rye grass prairies to the west, pine woodlands to the east. It offered deer and buffalo, turkeys and pecans, good trading, good raiding, ancient enemies to fight, and - for a long time - refuge from Spanish and Anglo American authority. ${ }^{4}$

Spanish parties had braved this complicated "Indian country" to travel back and forth on the old military road between Bexar and the Louisiana settlements for over a century, but 
otherwise they had left it alone. Their only show of force at the Colorado crossing had been a small guard post, manned by twenty or so soldiers for a few years after 1805. When Austin crossed the river in 1821, this guard post, called Puesta del Colorado by the Spanish, had been abandoned. ${ }^{5}$

By 1827 Stephen F. Austin was ready to expand his original colony to the north and establish a "Little Colony" of 100 additional families, based on a new community at the site of the Colorado crossing. Cotton agriculture in Austin's original land grant had proven a great success, and land-hungry Anglo American cotton farmers flocked to Austin's colony, both delighting and (to a degree) disturbing Mexican authorities. By 1826 settlers asked Austin to procure rights for their expansion farther up the Colorado Valley, and he agreed to do so. Historian Kenneth Kesselus wrote:

By late 1827 . . . Austin's efforts to settle the uppermost area of his original colony led to his petitioning for an entirely new colonial tract, calling for 100 new settlers and the important new town. In fact the principal reason for his application for the new colony was to gain jurisdiction over the place where he planned to build a new town, the present location of Bastrop. ${ }^{6}$

Austin's motives were mixed; he wanted a particular town site just north of the river crossing and needed to extend his colony to get it. He also wanted to honor his late friend Baron de Bastrop. Austin sold the idea to the Mexican government as a means of establishing a buffer against hostile Native Americans, and that also must have been authentically in his thoughts. Settlers on the northern edge of Austin's original land grant certainly had suffered more than their share of trouble with the indigenous populations.
The government of Mexico formally approved the new colony on November 20, 1827. By the middle of 1828 , settlers had moved in to claim lands along the river and sites at the river ford in a community that was first called Bastrop, then after 1834 (for political and administrative reasons), the Municipality of Mina (Figure 21). ${ }^{7}$ Settlers continued to call the place Bastrop, however, perhaps using the joking play on words noted by visitor Gideon Lincecum- "Bear Strap." ${ }^{\circ}$ The thickets and prairies around Austin's new community remained thick with game for three decades - deer, turkeys, buffalo, wild cattle, and black bear. ${ }^{9}$

Native Americans did not immediately give up their old hunting, trading, and raiding grounds, and from 1827 to 1845 Bastrop area settlers paid a price for serving as a wilderness buffer zone. Kenneth Kesselus aptly observed, "To say they were living on the frontier is a gross understatement, for Bastrop County was, until at least the mid-1840s, beyond the frontier, being vulnerable to Indian attack from all sides. This was by far the westernmost settlement in Texas, the deepest thrust into Indian territory." 10

That "Bear Strap" was also Indian country is amply demonstrated by the patterns and practices of early Anglo settlement. Families first located on lands along the Colorado to the far southeast of the new colony, only gradually moving up the east side of the river above the old Spanish road. New arrivals usually stayed with older settlers while locating their land, often a full league (4,428.4 acres). Lands along the river were most desirable. They had the best soils, springs nearby at the edge of the river valley, game and timber resources, and, most importantly, neighbors. Neighbors tended to do things together in the early days of Bastrop County. They lived close together, went to work 


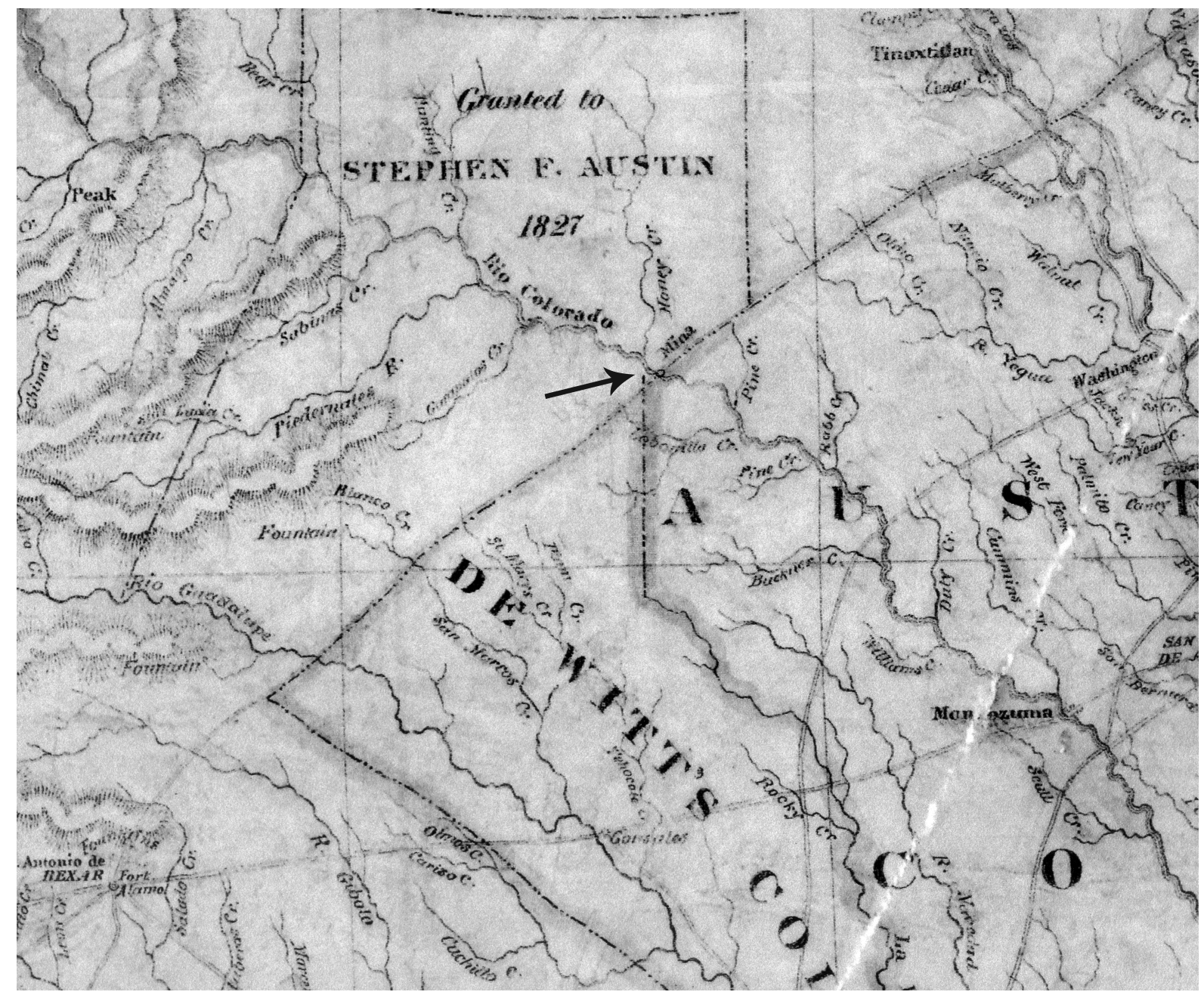

Figure 2-1. 1830 Map of Stephen F. Austin's “Little Colony” showing Mina, which was later renamed Bastrop (map courtesy of the Texas General Land Office).

the fields together, and often traveled in armed bands; the reason was Native Americans.

Settlers clustered in tight groups around log fortifications, as at Alum Creek, where seven families built a stockaded fort of split logs eight to ten feet high. They might build their firstgeneration $\log$ cabins within such a log stockade, or - perhaps more isolated - they might build one of the small, two-story log forts common on the southeastern frontier. ${ }^{11}$ The upper floor commonly overlapped the lower floor in these often windowless structures, allowing gunmen above to fire through slits to clear the walls below. Otherwise, it was too easy for attackers to set a fire and burn the settlers out. ${ }^{12}$ Noah Smithwick noted that the Ruben Hornsby family had settled across from Mitchell's Bend on the Colorado River, "the first settlement above Bastrop," and "built themselves a strong fort, which was several times attacked, but never carried." 13 The Hornsby family also believed in family solidarity and strength in numbers, and their settlement consisted of Ruben Sr. and wife, their six sons and their families, and their daughter and her family. ${ }^{14}$

As the memoirs of Noah Smithwick, John Holland Jenkins, and others make abundantly clear, a confusing array of Native American 
groups frequented the Bastrop area-friends, enemies, and every shade in between. Some, like the Tonkawas and Lipans, often joined with the Anglo Americans against their joint enemies - the Comanches. "Friendly Indians" came and went, and even Comanches might assume the friendly role when they felt like it, as during their peaceful trading visits to Bastrop in 1838. At their cotton plantation on the Colorado, Josiah Wilbarger and his wife depended on "friendly Indians" to "set up their tents and pick peas on the shares, or pick cotton for watermelons, corn, or beef." 15

At the time Wilbarger wrote, probably in the mid-1830s, virtually all settlement took place around the old river ford and along the Colorado River valley. The indigenous populations were varied, numerous, and of uncertain disposition and tribal allegiance. A settler could never be sure just who was out there and with whom he was dealing. Jenkins, Smithwick, and others mention encounters with Comanche, Coushatta, Caddo, Waco, Delaware, Tawakoni, Tonkawa, and Lipan Apache, among others. John Jenkins gave a real sense of this chaos. He mentions Comanches coming through "hunting Tonkawa Indians"; a band of Caddo who "came constantly in and out, pretending to be hunting and trying to seem friendly and honest"; a lone Delaware passing through, trapping beaver and oblivious of political events; and "for a time, bands of Indians . . . seen passing to and fro on their warfare against other tribes." ${ }^{.16}$

Native Americans might present themselves to pick cotton in trade for watermelons, or they might have other agendas. Many pages of John Holland Jenkins's memoir of the Bastrop area tell bloody stories of attacks on isolated farmsteads, plowmen riddled with arrows in their fields, travelers murdered along the road, and other violent deeds; these were often swiftly revenged by Anglo Americans, though not always upon the correct tribe. After something terrible happened, Anglos tended to vent their rage on the first Native Americans they encountered. Outlying settlers gave the "Indian alarm" by sounding a long blast on a cow horn followed by two shots. Bastrop settlers did this by firing two small cannons - the only use found for those devices in their Indian wars. Nevertheless, raiding parties sometimes boldly entered the town of Bastrop itself, murdering townspeople caught out alone, taking captives, stealing horses, and even stripping clotheslines of the week's washing. ${ }^{17}$

Native Americans often seemed to be one step ahead of the Anglos. For example, a plan in the spring of 1833 to stake out horses at Gill's Branch as bait for an ambush backfired when the Native Americans stole the tethered horses in broad daylight; their would-be ambushers were home eating supper. ${ }^{18}$ Travelers commonly tethered their horses to their wrists at night while they slept as a preventative against horse theft, but sometimes they woke up at first light with horses gone and reins severed a few inches from their wrists. ${ }^{19}$ At a time before repeating firearms, the military match-up was not very favorable, especially when it came to actions on horseback, as it almost always did. Comanches, in particular, rode superbly. Former Comanche captive Nelson Lee described how they would "lie along the sides of their horses, while under full speed, directing their course at the same time and discharging arrows from under their necks with deadly effect, in a manner astonishing to witness." ${ }^{20}$ After a mounted Anglo had fired his muzzle-loading rifle or musket at such an illusive warrior and missed, where would he go to reload safely?

No wonder, then, that Native Americans provoked much fear among Bastrop citizens, or 
that the town itself had a log fort at its center. A woman wrote in her memoir of those days:

The country was full of Indians - some hostile, some friendly. It was not safe to go out after sundown. A stout stockade was a necessity. One was situated in the part of town where now stands the courthouse, and there, when an Indian alarm was given, the women, children and old men were rushed, while the able-bodied men and boys scoured the country or met the Indians in their hiding places. $^{21}$

And no wonder also that fear provoked murder, and atrocity led to atrocity during these violent years. In 1835 Native Americans ambushed and killed store owner Amos Alexander and his son on Gotier Trace, the road through the pine hills from Bastrop east to San Felipe. A revenge party of "minutemen" led by Edward Burleson soon captured eight Native Americans that possibly had done the deed, and after a quick vote, the whites executed seven of the eight on the spot. ${ }^{22}$

Sometime during the dangerous 1830s, at a time when Bastrop citizens still periodically fired their cannons as a signal for women and children to take shelter in the log fort, a few pioneers dared to settle farther out in the woods and bottoms along Piney, Big Sandy, and McLaughlin creeks some miles to the north - the countryside that became Camp Swift. By the late 1830s various people owned most of this land, but only a few had the nerve to settle on it. Researcher Martha Doty Freeman found repeated mention of an "old fort" on the northwest bank of McLaughlin Creek on land surveyed for William McLaughlin in 1838. Perhaps the fort had been built by McLaughlin himself. Certainly, anyone who lived in this outlying area before 1840 needed a $\log$ fort! A man named David Holderman, his family, and his slaves resided in the area for certain.
Holderman came to Texas in 1832, and by 1839 lived on 2,725 acres valued at $\$ 9,086$. In 1840 , his holdings included 545 acres appraised at $\$ 2,180,12$ slaves, and 30 cattle. ${ }^{23}$ Skelton and Freeman reasonably conjectured that Holderman might have been trying to live "a plantation way of life" in this sandyland wilderness at a time when most plantations clustered along the Colorado River. Probably there were a few other early residents in the area, perhaps not all with formal land deeds. Squatting on other people's land was an old tradition of the moving Southern frontier. Libbie Wade Cameron told researcher Freeman that her grandfather, S. B. Chandler, also had owned slaves and practiced large-scale agriculture in the area. Deed records showed Chandler settling around 1854, although his granddaughter placed him on the land more than a decade earlier. ${ }^{24}$

No memoir or oral tradition detailed life at the first $\log$ homesteads on the drainages of Piney, Big Sandy, and McLaughlin creeks, but John Holland Jenkins and Cordelia Brown Harwood described the common circumstances of arrival in the area north of Bastrop in the 1830s. Jenkins recalled his party working together to build dirt-floored log huts. Then:

as soon as possible corn was planted, for our bread supply was getting very slim, and neither corn nor salt could be obtained nearer than the Brazos River. Once we were out of both, and we were compelled to live a while on dried turkey breast for bread, while our meat was unsalted venison. ${ }^{25}$

The Jenkinses battered corn to coarse meal with a mortar and pestle, then strained it through a buckskin sieve. Thereafter, "Upon our 'Johnny Cake' boards, as they were called, was baked as good bread as was ever taken from oven or stove. Our coffee was tied in a piece of buckskin and beaten upon a rock with another rock."26 
Venison as daily fare and improvising with buckskin were common on the Texas frontier. Whitetail deer and wild "Indian cattle" roamed everywhere in the Bastrop area, a basic resource of the place. ${ }^{27}$ In addition to making buckskin into sieves for cornmeal, settlers fashioned it into shirts, dresses, pants, chair covers, containers, bindings, bed covers, and other necessities. Wild cattle horn became blowing horns, powder horns, buttons, goblets, spoons, containers, and wall pegs. ${ }^{28}$

Cordelia Brown Harwood recalled staying with her mother and siblings at her uncle's home while her father and the family's slaves built three small, one-room log cabins from the virgin red cedar three miles north of Bastrop. "The cabins were erected in a cedar brake in order to make them more secure from Indian attacks," and a cabin apiece was built for family, slaves, and horses. ${ }^{29}$ Apparently, horses not actually shut up within a log structure were considered too vulnerable to Native American theft. The family's log house was large and constructed well, as Harwood described in words that would hold for most such first-generation log structures in the Bastrop area:

The cabin for our use was of cedar logs raised on cedar posts about two feet from the ground. The cracks between the logs were filled with the long grey moss which draped the oak trees. The house was made entirely without nails, and by the use of common work tools, such as an axe, saw, and hammer. The floor, made of logs split in half and smoothed with a broadaxe, was called a puncheon floor. The windows and doors were of clapboards which swung on homemade hinges of wood. The roof was also of clapboard. ${ }^{30}$

A mud-and-daub chimney with a rock hearth completed the one-room cabin, although most of the Brown family's cooking was done outside.
Doubtless the log cabin that Abner and Louisa Scott built near McLaughlin Creek around 1865 initially resembled the Brown's home, though the Scott home had a full rock chimney. Abner Scott relocated to the area from Fort Bend County in 1857 with his mother, older brother David, and David's wife and children, and Abner soon began to acquire land of his own. Abner and his wife Louisa added more rooms to this $\log$ house as their five children were born. Researcher Martha Doty Freeman wrote of Abner Scott:

The influence of the man spread well beyond the log cabin he built and grew to encompass a goodly proportion of the territory south to Piney Creek. By 1880 he was related by marriage to the Chandlers to the southwest; by 1900 his children or other relatives had built homes south of McLaughlin Creek which account in number for a significant percentage of all historic structures in the area. ${ }^{31}$

After the death of Abner and Louisa, Scott family members continued to use the house near the creek. Its last residents were Abner Scott's grandson and his wife, Grover and Ina Fay Scott, who moved into the structure after they married in 1922 and raised nine children there (Figure 2-2). ${ }^{32}$

Even in 1865 Abner and Louisa Scott had not lacked for neighbors in the post oak and red cedar uplands along McLaughlin, Big Sandy, Dogwood, and Piney creeks. A "Piney Creek Settlement" had been mentioned in Bastrop County documents as early as $1851 .{ }^{33}$ After troubles with Native Americans ended rather abruptly around 1845 , outlying areas became more desirable, and many of the first generation settlers and non-resident landowners sold out to the newcomers that flocked to Texas after statehood. ${ }^{34}$ Another wave of settlers arrived 


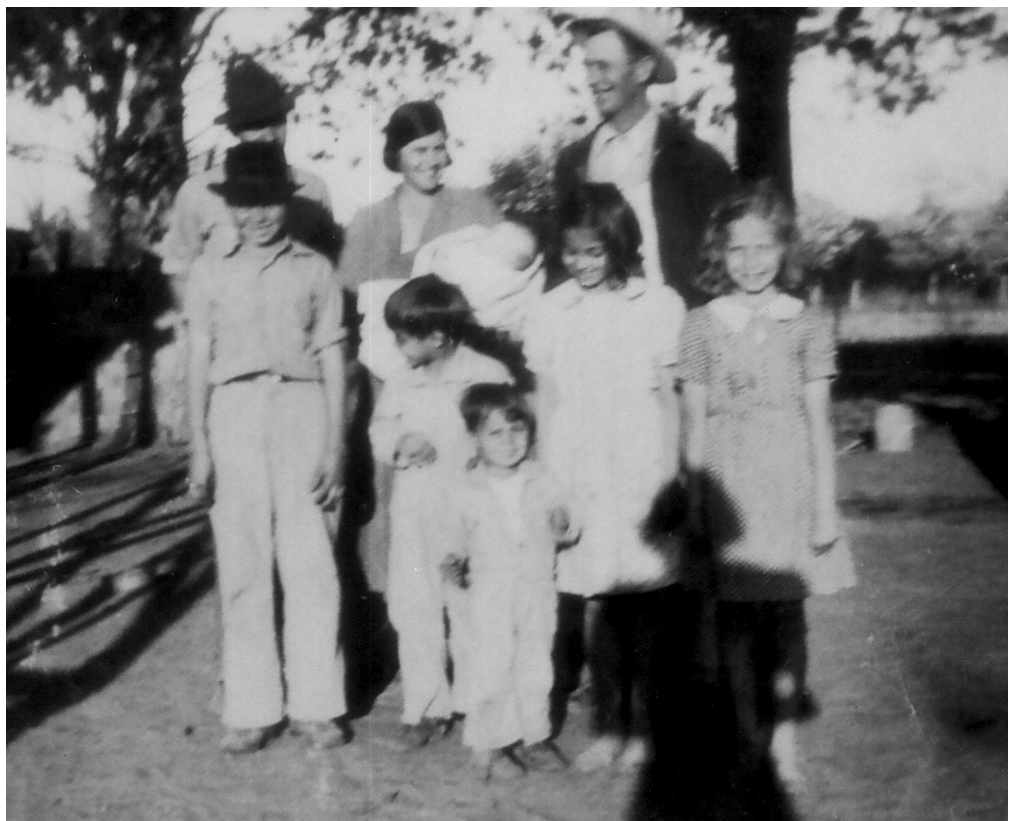

Figure 2-2. Grover Scott's family at the Abner Scott home ca. 1940 (Abner C. Scott). Abner C. Scott-rear left in black hat; Ina Scott (mother) holding Donald Scott-rear center; Grover Scott (father)-rear right in white hat; Dan Scott-left front in black hat; Allen Scott-front left center (looking away); Jesse Lee Scott-front right center (girl looking down); Mary Lou Scott-extreme right (girl looking at camera); Harlan Scott-small boy in front center.

in the decade following the Civil War. Some were former residents of the older Southern states, looking for a fresh start in a new land. Others were locally-freed slaves seeking their own "forty acres and a mule" after the federal government failed to provide them. ${ }^{35}$ Here and there across the sandylands of northern Bastrop County, African Americans acquired land and joined the Scotts and other Anglo pioneer families. Once a single black family had landhold, others tended to follow and settle beside them, as in the area along Dogwood Creek. ${ }^{36}$

During the 1850 s and 1860 s, white and black families arranged themselves into informal, dispersed rural communities that southerners termed "settlements." Over time, these tended to give rise to a characteristic infrastructure of church, school, and graveyard, as at the Oak
Hill community located to the southeast of the Scott family's settlement of Spring Branch.

Oak Hill developed on a stretch of sandyland countryside along upper Piney Creek, mostly after the Civil War. Some people had occupied land in the area as early as the 1850s. Oak Hill's historians wrote:

These early settlers had to work hard. Cabins had to be built, either of hand-hewn cedar logs or lumber hauled from a sawmill near Alum Creek [Figures 2-3 and 24]. There were wells and cisterns to be dug, rails to be split, fences built, firewood to be cut, crops planted and harvested, not to mention cooking, cleaning, and mending. ${ }^{37}$

The first marked grave in Oak Hill Cemetery is dated 1868 , though the unmarked burials perhaps preceded it. One story told that a horseman unknown to local people fell dead from his horse and was buried nearby, thus beginning the cemetery. As time passed, a black burial ground developed just over the fence from the white graveyard. ${ }^{38}$ Oak Hill residents soon built a succession of two or more log structures housing both church and school a few hundred yards away from the cemetery, the first possibly prior to 1872 . By 1880 or thereabouts, Oak Hill had a separate school building and union church, the latter serving Methodists, Presbyterians, and Baptists. ${ }^{39}$ Somewhere nearby, a small store and a steam-powered cotton gin and grist mill completed the typical infrastructure of the Southern settlement in the heyday of cotton and 


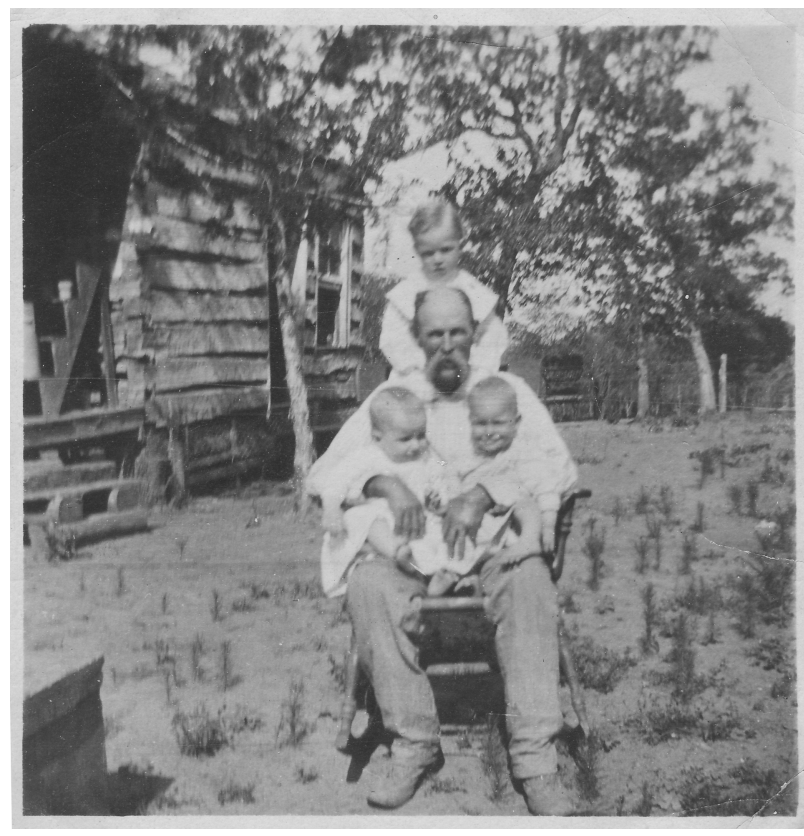

Figure 2-3. Andrew Owen standing above his grandfather, T. W. Owen, who is holding Thurston and Hollis Stagner in front of an original log house at Oak Hill (Fay Owen Pannell). corn. At Oak Hill and everywhere else in the rural South, cotton long remained the key money crop. Indian corn was the key subsistence crop that powered the work stock, fed the domestic animals, and provided the daily bread.

Railroads building west and south after 1871 brought additional farm families to the northern Bastrop County countryside and spawned new market towns, large and small, along their tracks. The Houston and Texas Central Railway built west from Brenham to Austin during the early 1870s, creating the town of McDade and the larger community of Elgin on the northern edge of the Camp Swift lands. ${ }^{40}$ In 1886 the Missouri, Kansas, and Texas Railroad built south from the Houston and Texas Central to the county seat of Bastrop, creating the

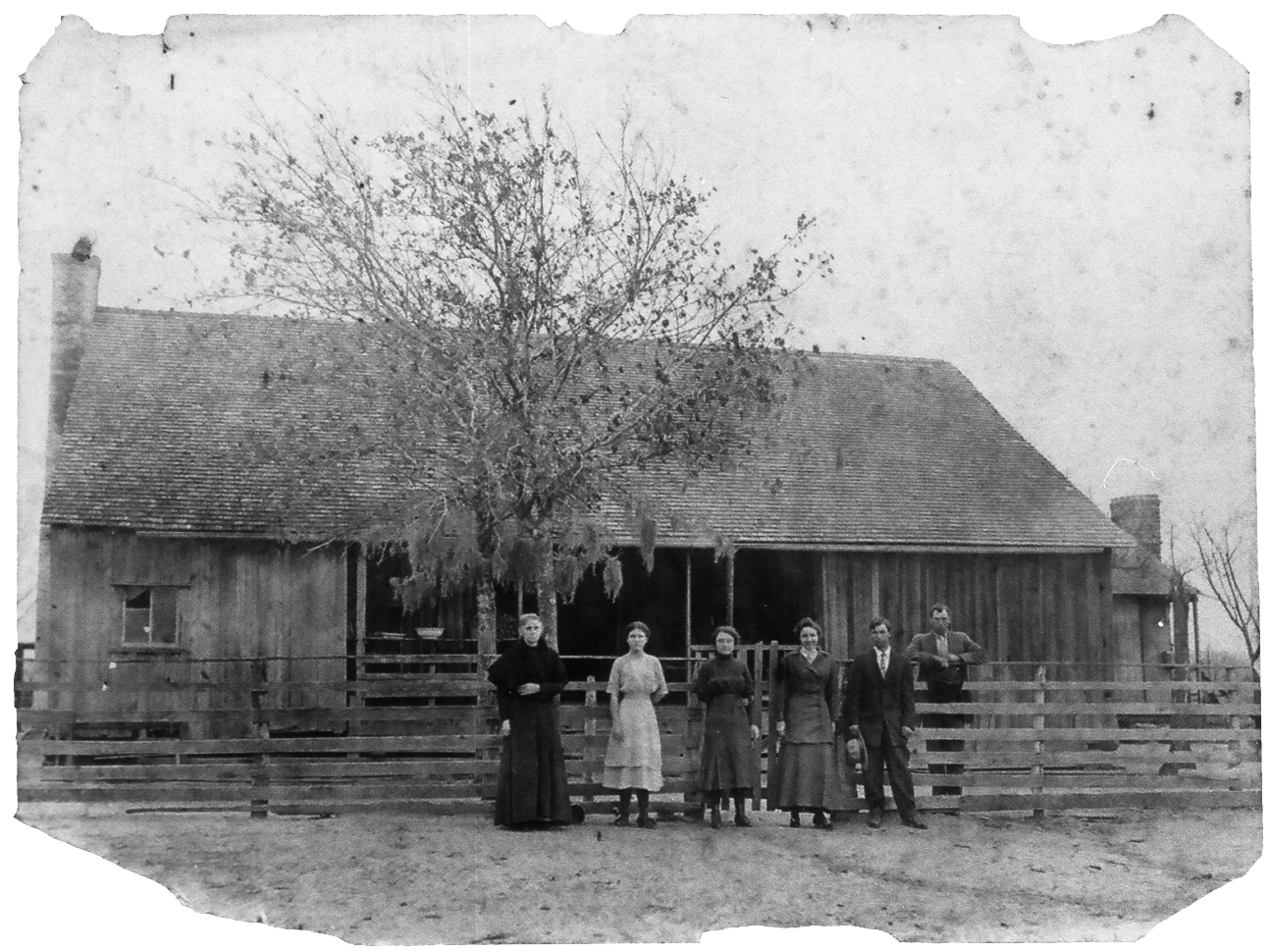

Figure 2-4. Early Oak Hill board-and-batten frame house. The house was still standing at the time of the takeover. Resident Ruth Allen Hancock and her 5 children in front of the family home, date unknown (Ruth E. Smith). 
depot stop and settlement of Sayers (also called Sayersville) just to the west. ${ }^{41}$

A rapid rise in county population accompanied the railroads, followed by a time of troubles associated with the social turmoil of Reconstruction, the rise of Jim Crow, and the end of free range for cattle. Sayers-area resident H. N. "Man" Bell and his three brothers worked in Bastrop County law enforcement from the early 1880 s to the early 1890 s, and one of them died by an assassin's bullet in the dark streets of McDade. W. J. Bell served as Bastrop County sheriff from 1884 to 1886 . Man Bell followed him in office from 1886 to 1890 and continued as deputy sheriff until 1905. In one way or another the Bell brothers dealt with the outbreak of racial violence in the Cedar Creek community (and the murder of black leader Cal Thompson), the troubles over ending the Bastrop County free range, and the decadeslong cycle of murder and vigilante justice that took place in and around McDade. ${ }^{42}$

Despite such nearby troubles, newcomers continued to arrive during the $1880 \mathrm{~s}$ and $1890 \mathrm{~s}$, further populating the communities along Piney, Big Sandy, Dogwood, and McLaughlin creeks. Many joined relatives already arrived at Oak Hill, Piney, Wayside, Sayers, and other communities, then over time rented or purchased farms of their own (Figure 2-4). The countryside filled up, and for several decades virtually everybody tried to make a living by raising cotton. Steam gins prospered at Oak Hill and Sayers, proof of how successfully cotton grew on the local sandylands, at least until the soil was depleted from repeated crops and the boll weevil infested the area. Bastrop County population and cotton production tracked together in a steady growth to a peak in 1900 , at which time a county population of 26,845 residents on 3,509 farms produced the all-time high of 41,730 bales. ${ }^{43}$ Thereafter, farms, cotton, and population all began a slow decline, and the county did not see 28,000 inhabitants until the construction workers for Camp Swift arrived in 1942.

The decline in local cotton production forced the Oak Hill and Sayers gins to close by 1918. On the Blackland Prairie of neighboring Williamson County to the north, however, things were entirely different, and the difference increased over time. The sandylands of Bastrop County produced 23,795 bales in 1910; the Blackland Prairie in Williamson County produced 79,616. In 1916 the respective Bastrop/ Williamson figures were 27,479 and 117,268, while in 1920 they were 28,950 and $168,509 .{ }^{44}$ In a good or average rainfall year-for example, 1924 - Williamson soils produced one-third of a bale per acre, and Bastrop one-fourth of a bale, but in a dry year the greater drought resistance of the Blackland soil had its effect. ${ }^{45}$ In fact, in 1929 it took over seven acres of land in Bastrop County to produce one bale of cotton, but only four acres to produce the same in Williamson County. ${ }^{46}$

Not surprising, then, that the Oak Hill and Sayers gins closed, and that local farmers began to produce other cash crops on their farms. The classic Southern frontier economy of cotton and corn shifted toward the production of melons, sweet potatoes, peanuts, dairy products, and free-range turkeys. Such things did well in the sandy soils and post oak woodlands along the creeks. It was hard to get rich on the sandylands, but - given enough corn in the field and hogs in the creek bottom - it was hard to starve. Furthermore, the annual cotton boom on the nearby Blackland Prairie could be tapped for ready cash: cotton-picking money in the fall, when every prairie-land farmer sought desperately for hands to harvest his crop; and 
money for locally-cut post oak and blackjack oak cordwood, which was combusted in prodigious quantities by Blackland Prairie steam gins.

By 1920, about 350 families occupied properties along and between Big Sandy, McLaughlin, Dogwood, Piney, and Alum creeks, on the triangular 87 square miles of countryside that would become the World War II training facility of Camp Swift. ${ }^{47}$ The creeks generally flowed from north to south toward the Colorado River, dissecting a rolling landscape of woodlands, fields, and pastures. Despite the creeks, water for home use and livestock remained a problem for farmers on the sandylands. Big Sandy Creek was the only one that never ran dry. Local fields could produce abundantly, but adequate rain was needed. Cotton is a drought-resistant crop, but at harvest time in some years Oak Hill farmers reported to the Bastrop newspaper that "they will not make enough [cotton] to take the sack to the field." ${ }^{38}$ In 1920 more families lived on the better soils of the northern half of the triangle than lived south along Highway 21. Local people knew this watershed of Alum Creek as the "sand hills," a remote, sparsely-populated area located within the northernmost section of Lost Pines. ${ }^{49}$

Within the triangle of highways "an almost bewildering maze of primary and secondary roads leading from neighbor to neighbor" ${ }^{30}$ traversed the landscape. It was easy to make new roads across the sandy countryside, and the pioneers and the sons of the pioneers had made a lot of them. The main roads (all dirt, or more precisely, sand) were the SayersMcDade Road, which ran northwest-southeast through the area; the Oak Hill Road, which ran southeast from the Sayers-McDade Road to pass by the Oak Hill Cemetery; and the Scott Falls Road, which ran northeast from the SayersMcDade Road to Elgin. However, other roads, both public and private, wound about in every direction, and were rarely well-marked. It was easy and common for strangers unfamiliar with the surrounding area to get lost on them. ${ }^{51}$

Community allegiance was informal, and in part, a matter of personal preference. If asked about it, two neighbors along a road might say that they lived in different communities (Table 2-1). The Wayside, Spring Branch, Piney, and Dogwood communities had their adherents, but of these, only Wayside and Piney had schools (Figure 2-5). Piney had two one-teacher schools, one black and one white. ${ }^{52}$ The small railroad market town of Sayers lay just west of Highway 95, outside the westernmost edge of the 87 square mile triangle, but Sayers's hinterland extended well to the east. Sayers was mostly African American, and virtually all black public school students from the 87 square miles trekked into Sayers for their education. No white school operated in the Sayers Common School District by 1920. Likewise, most Anglo students from the area traveled to the threeroom Oak Hill School (Figure 2-6) on the far eastern side of the triangle. Oak Hill also had a union church, well-attended summer revivals, and a famous cemetery cleaning and picnic that drew participants from all around. ${ }^{53}$

As informants often attested (and archaeological digs confirmed), landowner or renter, black or white, few families on the sandylands of Bastrop County were better off than any other, and some of the Jim Crow segregations rigidly enforced in the county seat of Bastrop seemed loosely enforced in the countryside. ${ }^{54}$ Black and white children occasionally played together. Whites sometimes allowed blacks in their front doors, shook their hands, invited them to sit down at their eating tables, and did other things that were anathema to strict interpretations of Jim Crow. Life on 
Table 2-1. Community affiliations of the Camp Swift Oral History Project interviewees.

\begin{tabular}{|l|l|l|}
\hline Interviewee & Community Affiliation & School Affiliation \\
\hline Gertrude Dunkin Barton & Oak Hill & Oak Hill, Bastrop \\
\hline Mary Lou Reese Benford & Sayers & Sayers \\
\hline Leola Blackwell Carman & McDade, Oak Hill & Oak Hill, Bastrop \\
\hline O L Flowers & Sayers, McDade & Sayers \\
\hline Dean Fort & Scott Falls, Oak Hill & Elgin \\
\hline Erhard Goerlitz & McDade & McDade \\
\hline Louise Smith Goerlitz & Oak Hill, McDade & Oak Hill, McDade, Bastrop \\
\hline Ruby Mae Thomas Johnson & Sayers, McDade & Sayers, Elgin \\
\hline Morris J. Kastner & McDade & McDade \\
\hline JoNell Hancock Majors & Oak Hill, McDade & Oak Hill, Bastrop \\
\hline May Belle Miller Morriss & Glenham, Phelan, Oak Hill & Glenham, Oak Hill \\
\hline Fay Owen Pannell & Oak Hill & Oak Hill, Bastrop \\
\hline Abner C. Scott & Wayside, Spring Branch, Oak Hill & Wayside, Oak Hill, Elgin \\
\hline S. J. “Jack” Scott & McDade, Wayside, Scott Falls & N/A \\
\hline Ruth E. Smith & Oak Hill & Oak Hill, Bastrop \\
\hline Walter L. Thomas & Sayers, McDade & Elgin \\
\hline Irene Fleming Watson & Oak Hill & Oak Hill \\
\hline Evelyn Cottle Wilson & Oak Hill, Wayside & Oak Hill, Bastrop \\
\hline
\end{tabular}

the sandylands had a socially leveling effect; everybody was poor together. Walter Thomas's mother sometimes worked for white families in the Scott Falls area, but, as Walter said:

Black and white would help each other out. There's a lot of white people back in those days that didn't have much of anything, and when you go to work for them they had to pay you off with a little bit of meat or some kind of vegetable. People were just about in the same boat. ${ }^{55}$

Elgitha Owen helped her husband Joe operate a store in Sayers between 1911 and 1916 (Figure 2-7), and she recalled that blacks outnumbered whites locally but "everybody was friendly and neighborly."
Owen's customers included black and white and were mostly poor farmers, "just the kind of small farmer making a bale or two of cotton a year." ${ }^{56}$ Some African Americans operated local businesses - blacksmith Walter Madison, for

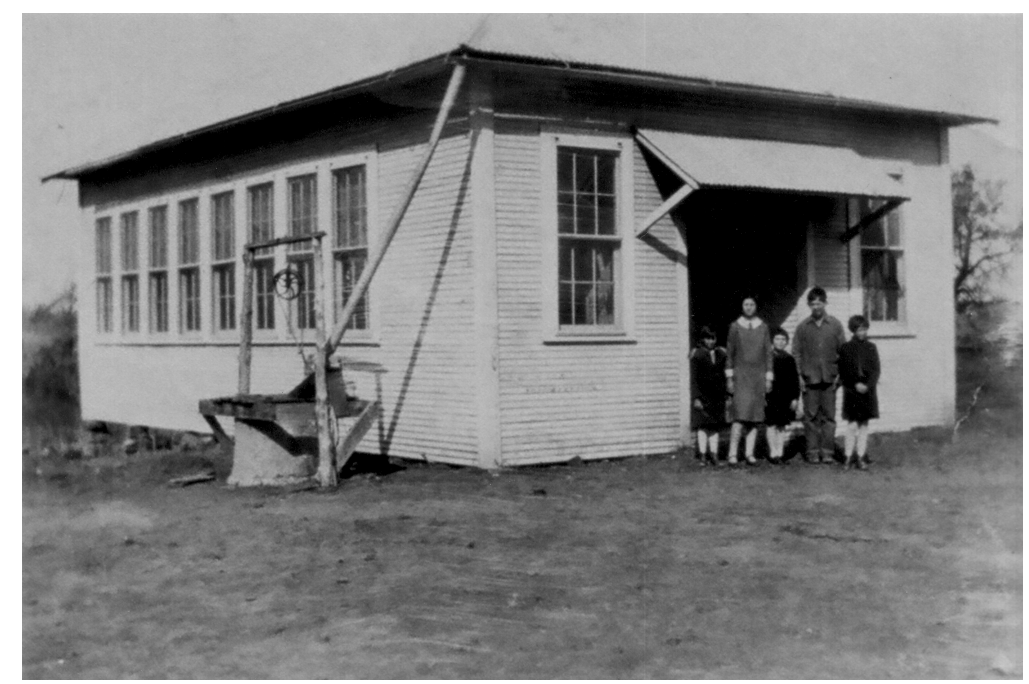

Figure 2-5. Wayside School ca. 1927-1928 (Jonathan Fleming). 


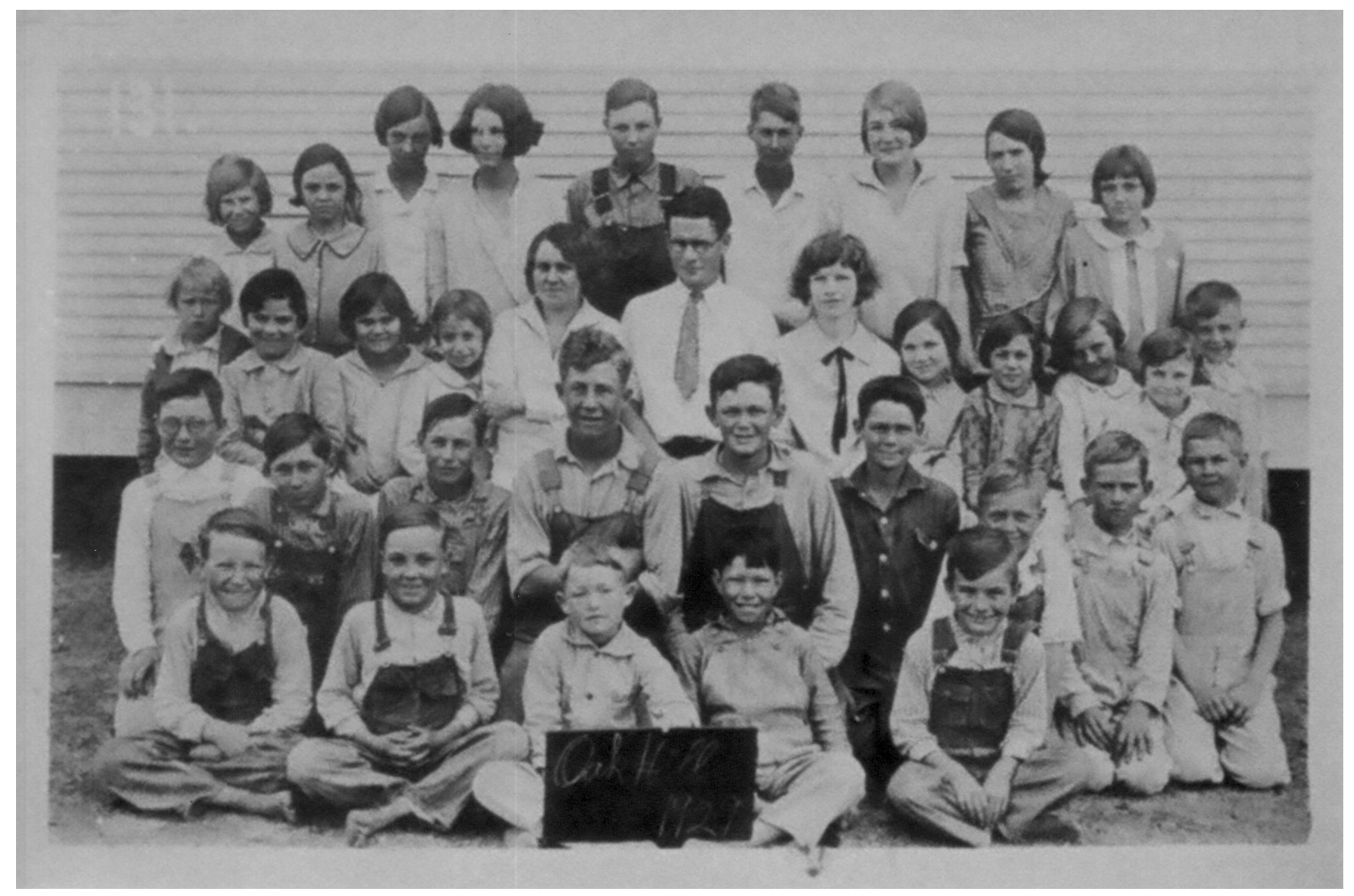

Figure 2-6. Oak Hill School, 1929 (Ruth E. Smith).

example. Black and white wood cutters supplied large amounts of cordwood to a local buyer, who shipped it out by railroad. An elderly freedman named Jim Perkins was well known to all Sayers residents (and in fact to those in the countryside for miles around). For some reason, Perkins stood in his yard and blew reveille on a bugle at first light almost every day. He lived miles from Sayers, but "on a clear, still frosty morning before dawn, you could hear him blowing his bugle all over the countryside. Just celebrating his freedom, some said"; 57 Perkins also celebrated the arrival of each New Year at midnight. ${ }^{58}$

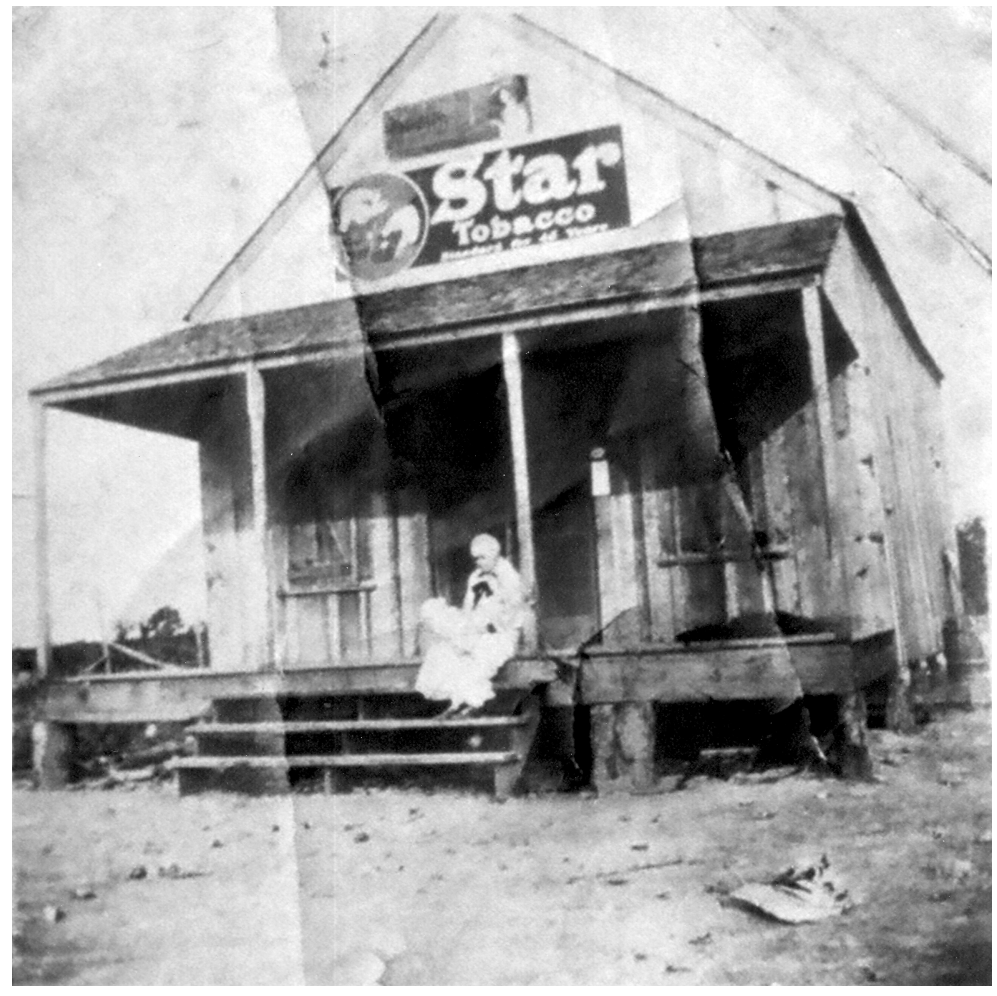

Figure 2-7. Sayers Store, date unknown (Fay Owen Pannell). 
Bastrop authorities sometimes had little use for Sayers's atypical racial harmonies. After Sayers residents petitioned Sheriff Woody Townsend for an unsalaried black deputy for the community in 1905, and their nominee dared to show up at the sheriff's office to ask for his commission, Townsend assaulted him with a club. The editor of the Bastrop Advertiser reported this incident with amused approval. ${ }^{59}$

People who lived on the Bastrop County sandylands often believed that townsmen in the county seat looked down their noses at them as "poor whites" or even "white trash." One anonymous farm woman stood beside her urban sister on the streets of Bastrop when the sister (herself only a few years removed from the sand hills) remarked of passers-by, "Well, you can look at them old women and tell they're from the country."

In truth, countryside and courthouse towns often had very different lifestyles in 1920 and for two decades thereafter. Residents at Oak Hill, Wayside, and Sayers drank well water, burned kerosene lamps, and frequented outdoor toilets (or the brush) until the land taking of World War II. While some farmers on the Blackland Prairie anticipated modern agribusinessmen, sandyland farmers often persisted in an older, subsistence-based style of agriculture. ${ }^{60}$ The backwoods farming lifestyle, with the "four essential elements" of "corn, hogs, ax, and fire," lasted longest in the sandy, post oak uplands, which were ecologically well-suited for raising free-range swine and turkeys and, in some places, had no stock law well into the $1920 \mathrm{~s}^{61}$

Bastrop County had a stock law, and most cattle on the sandylands were behind fences, but the local custom for hogs was: "hog-turning-out time, October 15" and "hog-penning-up time, February 15."62 By general agreement, farmers in rural communities like Oak Hill disregarded the stock law to let their hogs out after crops were gathered so the animals could fatten on acorns in the woods. Hogs wandered freely through barbed-wire fences and across property lines in the process, but their owners penned them up again before spring planting. ${ }^{63}$

Old ways of doing things, such as this modified free-range practice, tended to persist in the sandylands. In 1920 families like the Scotts still lived in log houses, their rooms aromatic from the red cedar cut two-thirds of a century before. Tractors still were rare farming equipment in 1920, when most local farmers found horses and mules quite adequate to plow their light soils, and some people even continued the use of oxen. Annie Hardin of the Sayers community remarked to her interviewer of those days:

Back then we cooked on a fireplace. Grandma would make ash cakes out of cornmeal - you whip them up real stiff and bury them in the ashes to cook. We made soap out of the lye. We sewed our clothes by hand - we wore patches and went barefooted. But back then we had fun. Instead of TV we'd sit up at night and tell riddles. I can't recall what we didn't eat. We ate hominy, parched corn, wild greens, bull nettle seeds, hackberries, black haws, dewberries. ${ }^{64}$

Annie Hardin had passed on by 2004 , but oral historians found other voices to tell what life was like in the 87 square miles of sandyland Bastrop County countryside that became Camp Swift. The pages that follow use these voices to continue Hardin's exploration of that rural world during the last two decades of its existence, from 1920 to 1942. 


\section{Endnotes}

1. Doughty 1983:31

2. Kesselus 1986:55

3. Campbell 1986

4. Kesselus 1986:11

5. Skelton and Freeman 1979

6. Kesselus 1986:35

7. Marks 1996a:412

8. Kesselus 1986:68

9. Jenkins 1958:233-236

10. Kesselus 1986:86

11. Bastrop County Historical Commission 1983

12. Jordan 1978:159

13. Smithwick 1983:191 [1900]

14. Ibid.

15. Kesselus 1986:203

16. Jenkins 1958:10-11

17. Kesselus 1986:204-210

18. Kesselus 1986:90

19. Smithwick 1983:81 [1900]

20. Kesselus 1986:15

21. Kesselus 1986:205

22. Kesselus 1986:132

23. Skelton and Freeman 1979:90

24. Skelton and Freeman 1979

25. Jenkins 1958:6-8

26. Jenkins 1958:6-8

27. McAuley 1986

28. Doughty 1983:26

29. James 1953

30. Ibid.

31. Skelton and Freeman 1979:93

32. Skelton and Freeman 1979

33. Kesselus 1987:33
34. Leffler 2001

35. Sitton and Conrad 2005:18-42

36. Pannell and Cailborne 1991; Thomas 2004

37. Smith and Pannell 1984

38. Pannell 1985a

39. Smith and Pannell 1984

40. Marks 1996a:412

41. Buder 1996:907

42. Barkley 1970:84; Marks 1996b:390; Wharton 2000:127-133

43. Marks 1996a:412

44. Texas Almanac 1926:141-142

45. U.S. Bureau of the Census 1927:1207, 1238

46. Texas Almanac 1933:143

47. Leffler 2001

48. Owen September 12, 1935

49. Pannell 2004; Smith 2004

50. Skelton and Freeman 1979

51. Ibid.

52. Texas State Board of Education 1937:206-208

53. Smith and Pannell 1984

54. Pannell 2004; Thomas 2004, Flowers 2004

55. Thomas 2004

56. Trepagnier 1983

57. Ibid.

58. Ibid

59. Gonzales and McAuley 1982

60. Smith and Pannell 1984

61. Sitton and Utley 1997:28; Jordan and Kaups 1989:123

62. E. Goerlitz 2004

63. Smith 1985; Barkley 1970:105

64. Trepagnier 1983 


\section{Chapter 3}

\section{Life in the Countryside}

\section{Homeplaces}

Perhaps there were a few grand farmhouses on the north Bastrop County sandylands, but none of the people we interviewed recalled living in such places. Fay Owen Pannell grew up at on an 88-acre farm near Oak Hill in a household composed of father J. D. "Joe" Owen, mother Elgitha, and four brothers, and Fay's home was about the norm. Joe Owen had hired others to build the structure, "a poor old ugly house," one story, nearly square, of board-andbatten construction, and a peaked roof (Figure 3-1). The Owens' home had a deep porch on the front, a combined kitchen and dining room, and three bedrooms. As the only girl, Fay got a bedroom to herself, but this mattered little in the summertime, when the terrible Texas heat (and the residual heat from wood-stove cooking) caused the family to move their beds to the front porch or even the front yard.'

Irene Fleming Watson lived in a similar house not far from the Owens' - a board-andbatten home with no internal walls and "cracks so big you could almost pitch one of kids through there." ${ }^{2}$ Despite the porous construction, the house's small windows, lack of a central hall, and hot wood stove also forced the family to the porch or yard at night. There was nothing unusual about this in a time before electricity, fans, and air conditioners, and the Flemings thought they "had a good house."3 Sleeping on the porch and in the yard was not altogether

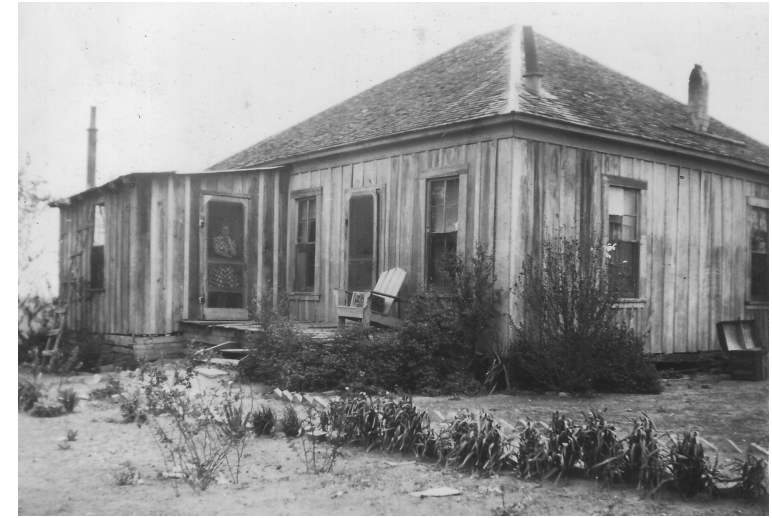

Figure 3-1. Joe Owen's family home in Oak Hill, 1935-1940 (Fay Owen Pannell).

a hardship, since, as Louise Smith Goerlitz recalled, "you could see the stars, the shooting stars, at night." "The Harvey Smith family lived in a rented house for several years, then moved into the DeGlandon (Louise's maternal grandparents) House in Oak Hill (Figure 3-2), and finally moved into Harvey's parent's house after their death (Figures 3-3 and 3-4). ${ }^{5}$

Area farmhouses often required only short descriptions, as in the case of Bettye Blackwell Light's recollection of her childhood place: "Just four rooms and a tin roof - I could lay in bed and see light through the roof, and it would rain on us when it rained." 6 For some months the Blackwell family's do-it-yourself home remained under construction, with old quilts serving as doors and windows. The daily round at the Blackwell home during the hot summer included biscuits for breakfast, cornbread 


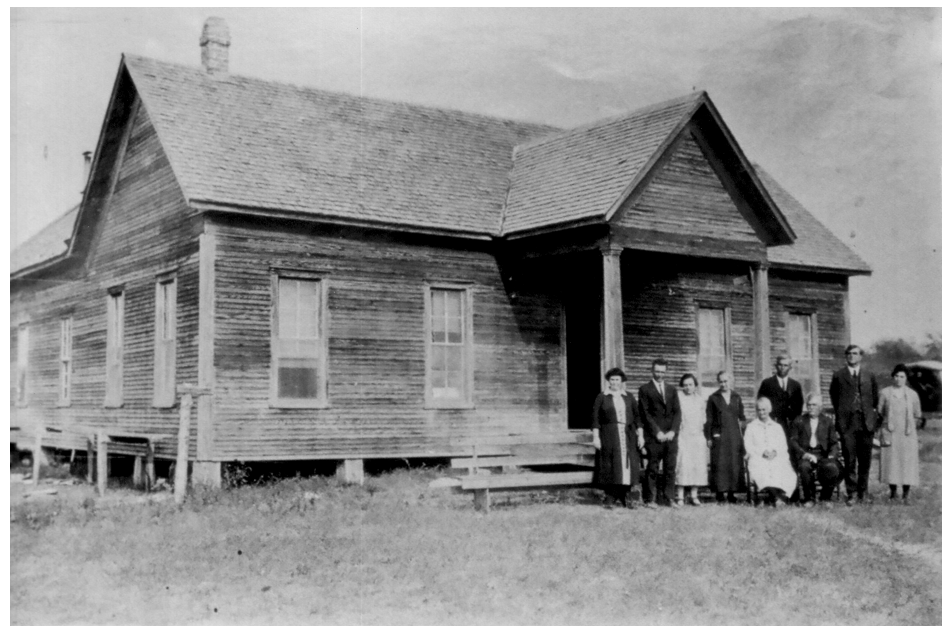

Figure 3-2. The DeGlandon House, 1930 (Louise Smith Goerlitz).

old songs and she had such a pretty clear voice. ${ }^{9}$

The loosely made, boardand-batten farmhouses were also drafty in the winter, and Jonathan Fleming's father was one of several persons who recalled looking up from his bed at frosty stars, glimmering through cracks in an unceiled, shingled roof. ${ }^{10} \mathrm{Big}$ families were common, bedrooms in short supply, and boys often drew hard-duty sleeping accommodations in the lofts or attics of peak-roofed one-story structures. More than one

at dinner, and "never a fire in the stove for supper." The family always ate a cold supper of leftovers from noon. In the evening, the Blackwells rested on quilts on the front porch while the house cooled from the day's heat, then moved inside to their beds by ten or eleven o'clock. The Blackwells' porch and house were unscreened, as was the case of virtually every other local house, so mosquitoes sometimes became a problem. Bettye, her sister Leola Blackwell Carman, and other family members rubbed exposed skin with kerosenedampened rags to repel the mosquitoes, although some people found this almost as unpleasant as the insects. Another dubious, bad-smelling remedy used by some was long-burning "smokes" of dried cow chips or dampened twisted tow sacks placed upwind after dark. ${ }^{8}$ Despite the mosquitoes, the night vigils on the front porch were not always unpleasant, as Bettye remembered in her memoirs:

While we were waiting the night to cool off and sitting in the dark, Daddy would ask Mama to sing something, and she would sing songs like 'Aunt Dinah's Quilting Party,' 'I Was Seeing Willie Home,' or 'Darling Clementine' — old,

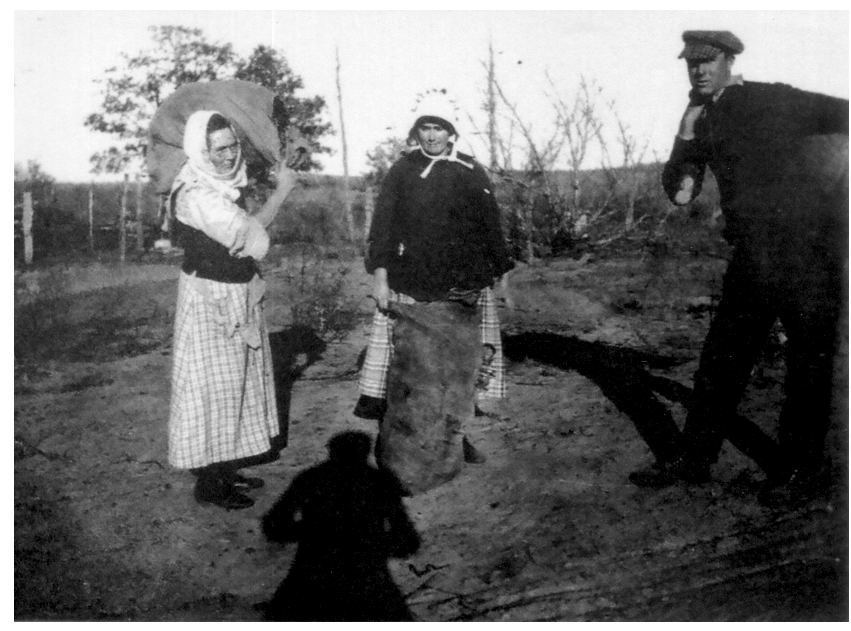

Figure 3-3. Louise Smith's parents and aunt at the old Harvey Smith farm (Ransom Place), 1920 (Louise Smith Goerlitz). 


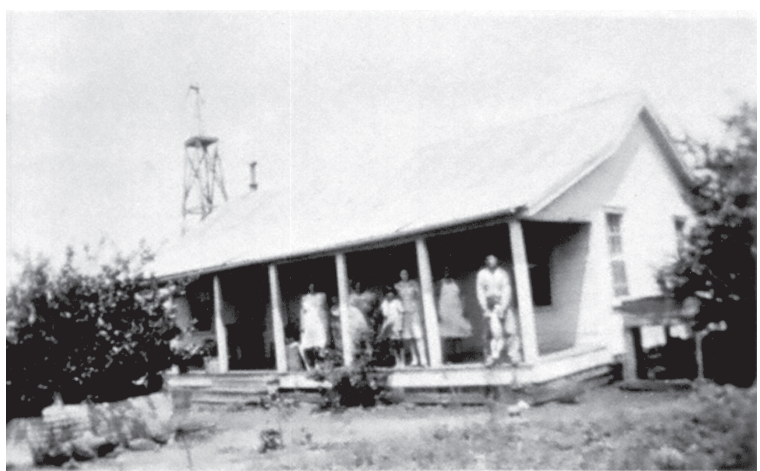

Figure 3-4. Harvey Smith's house at Oak Hill, late 1930s (Louise Smith Goerlitz).

on it to make it last the night. ${ }^{11}$ Other rooms in other houses were less warm and tight and required more quilts. Ethel Kelton Blackwell, Leola and Bettye's mother, often made quilts and kept a good supply in a big wooden quilt box. They remembered one day so cold that the family got up, ate breakfast, and then climbed back in bed once again under huge piles of quilts. Even in the wood-stove-heated kitchen, the house on that occasion seemed too cold to be tolerable. ${ }^{12}$ Irene Fleming recalled:

I've seen the times that we put all the quilts and blankets on the beds, and sometimes we'd have heavy coats and things that we'd pile on top. I'd tell my sister, 'Move over, you're taking up all the cover.' And she'd move over, she was asleep, and I'd just move her over out of her warm spot into the cold spot. ${ }^{13}$

The Hancock family of Oak Hill, lived in perhaps the best house with six rooms and beaded board walls (Figure 3-5). JoNell Hancock Majors' father, former gin operator Arthur Hancock, had excellent farmland, a fine buggy, and - from time to time - several black hired hands. Arthur needed help, since his child labor force numbered only three, and his wife Vivian (Figure 3-6) chose not to work in the field. He bought an early automobile and drove it to attend church at McDade almost every Sunday. Arthur's relatives joked that the family needed the car so that Vivian could drive to Austin to purchase white bread. ${ }^{14}$

Some larger, bettermade homes on the Bastrop sandylands dated back into the mid- to late nineteenth century, a time when farms had been larger, soils more fertile, and cotton fields more productive. An example was the Ransom house at

Figure 3-5. Floor plan of Arthur Hancock's house in Oak Hill (JoNell Hancock Majors). 


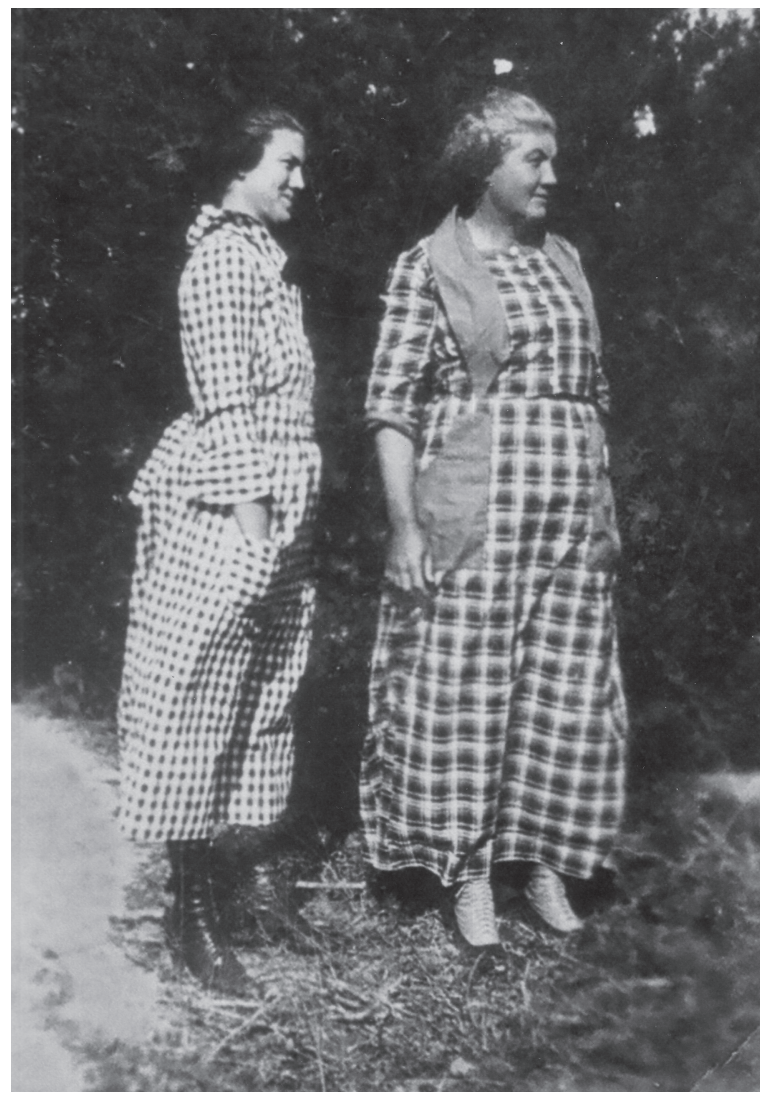

Figure 3-6. JoNell Hancock's mother (Vivian Buffa Hancock) and grandmother (Ida Scarborough Buffa), date unknown (JoNell Hancock Majors).
Oak Hill, a double-pen house of thick red cedar logs, with a dog run up the middle and brick chimneys at each end, built by John Ransom in 1853 (Figure 3-7 and 3-8). ${ }^{15}$ Abner C. Scott's home near McLaughlin Creek perhaps also fell into this category. The original Abner Scott had pioneered the property with a one-pen $\log$ cabin at the time of his marriage around 1865. As the Scotts added children, they added rooms to their home, though the original $\log$ structure remained, embedded in the larger frame home (Figure 3-9). A succession of Scotts inherited the house, over the years. ${ }^{16}$ Evelyn Cottle Wilson's family rented the 400-acre Coulson place and lived in another substantial farmhouse, which also dated from before the Civil War. The Coulson house was a one-story, six-room, frame structure with big porches and a large multi-purpose central room, with fireplace and fine cedar floor, and was often used for parties for young people. Though Evelyn's family rented the place, they acted like owners. Her father planted peach trees and

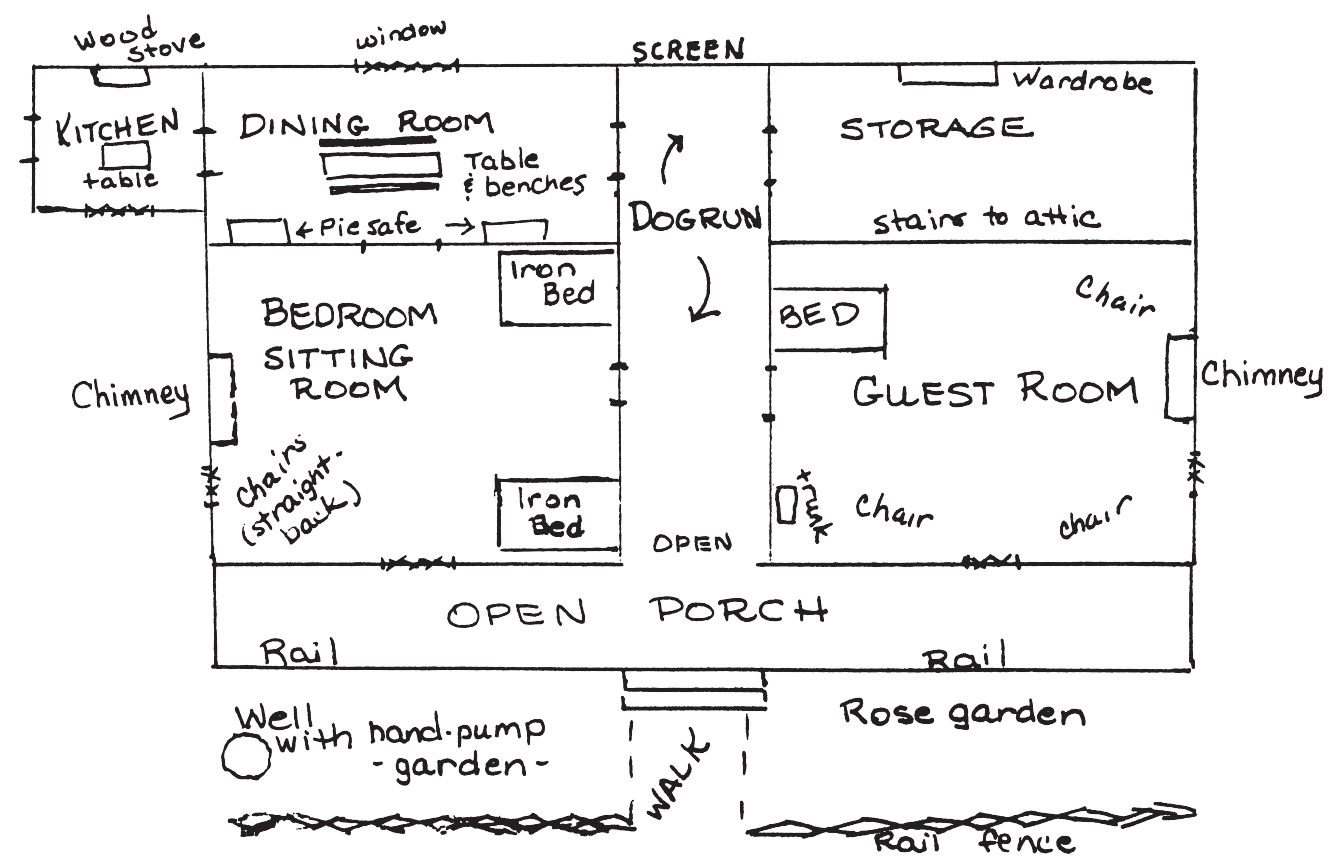

Figure 3-7. Floorplan of the John Ransom House at Oak Hill (Sayersville Historical Association 1998). 


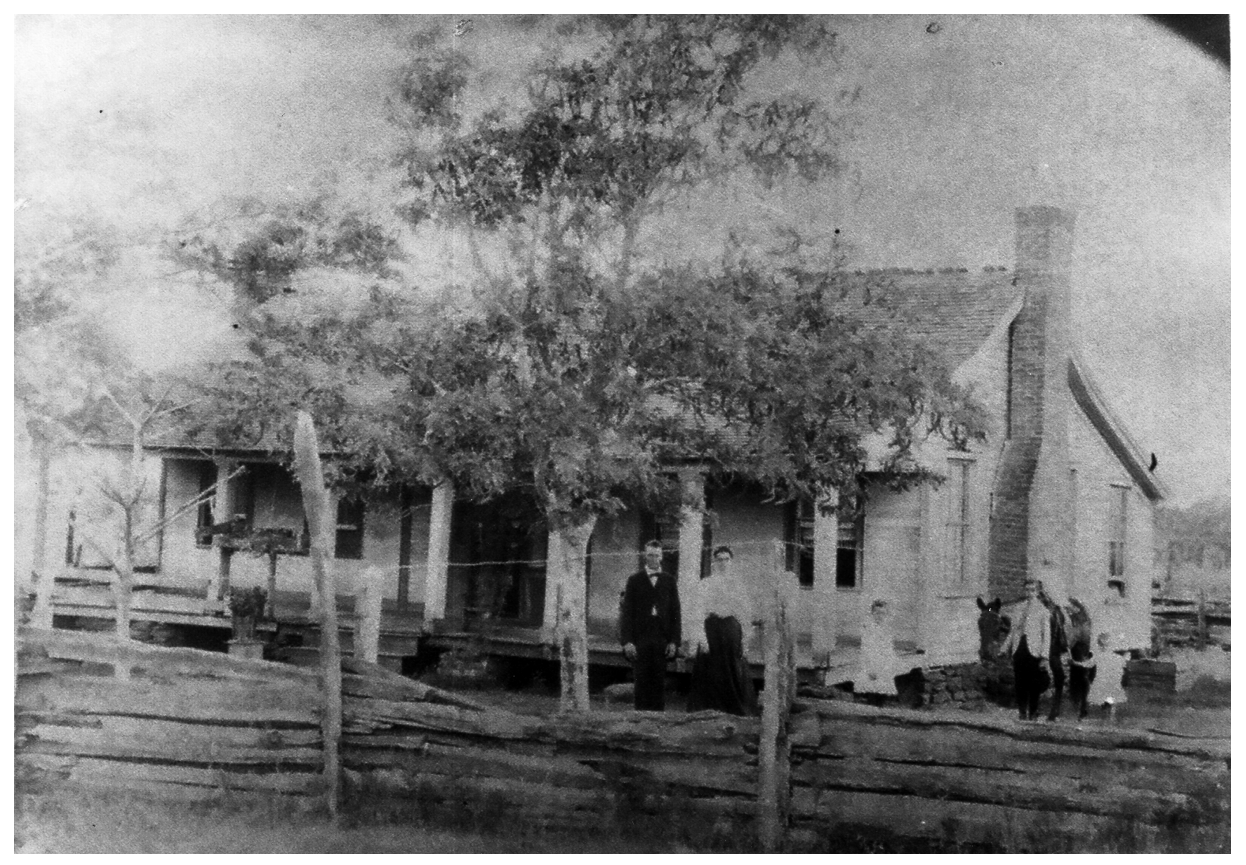

Figure 3-8. John Ransom House at Oak Hill, date unknown (Ruth E. Smith).

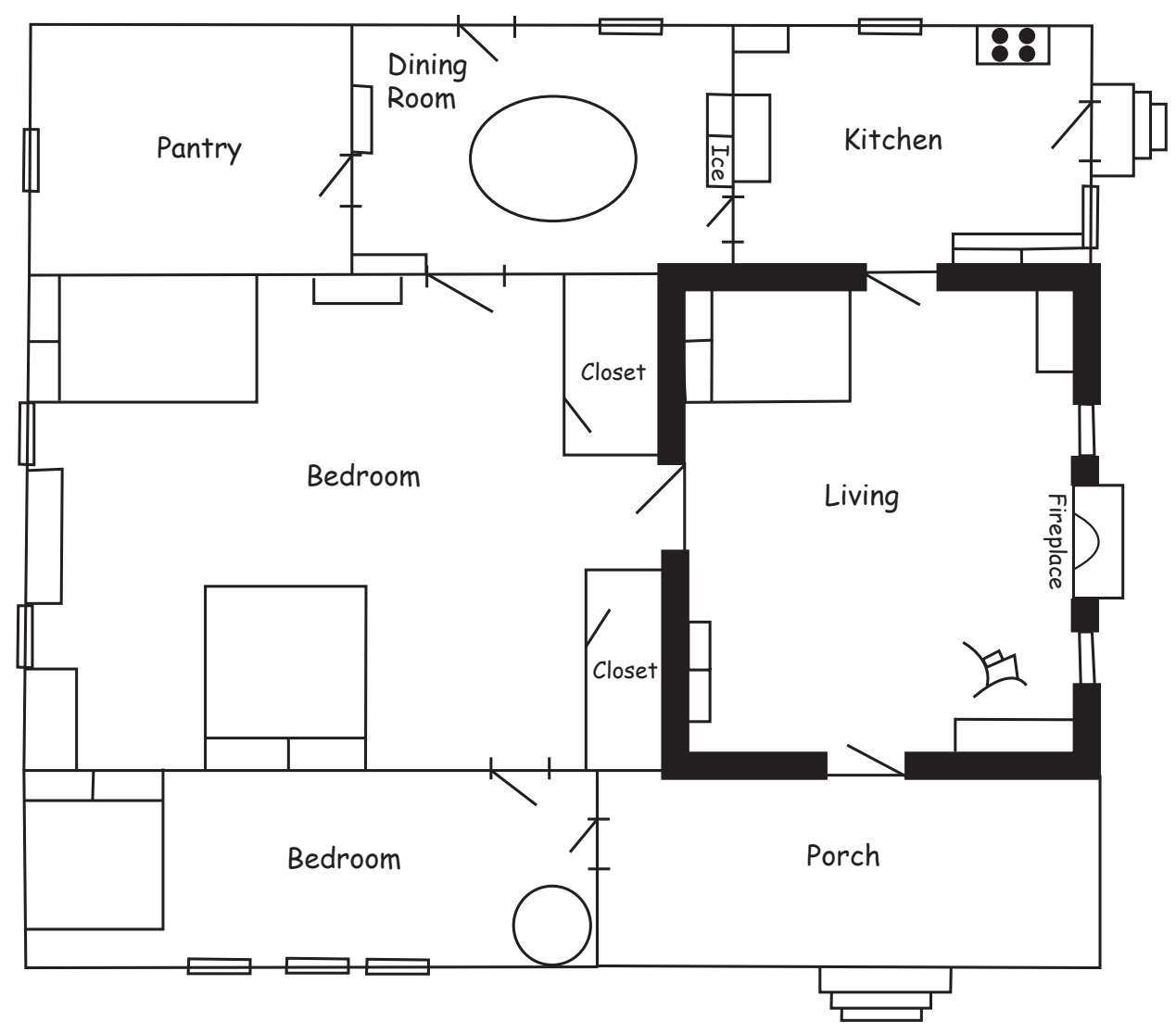

Figure 3-9. Diagram based on a sketch map drawn from memory by Jesse Lee Scott (Abner C. Scott's sister) of the original log cabin built by Abner Scott (Abner C. Scott's great-grandfather) around 1850, plus subsequent frame additions (Abner C. Scott). 
a berry plot, and her mother cultivated a flower garden in the angle of the L-shaped house. ${ }^{17}$

\section{Black Families in the Sandylands}

African Americans lived as renters and small landowners, scattered among white families on the Bastrop sandylands. Generally their farmhouses were poorer and their material possessions fewer than those of the whites, but not by much, and not always - not here on the sandy soils of northern Bastrop County. Sometimes, as on the Kastner family's farm, the landowners lived in board-and-batten homes little better than those provided to their renters. ${ }^{18}$

Some black landowner families resided on properties acquired by freedmen grandparents soon after emancipation. Sam Evans, Mary Lou Reese Benford's grandfather, and Jackson Morgan, Walter Thomas's grandfather, had acquired considerable acreages in the first decade after slavery, and at least in the case of Evans, the land had been carefully subdivided among his children before his death. ${ }^{19}$ A precious landhold had been passed down, along with a few old farmhouses that bespoke of larger acreages and better days. Walter Thomas's mother had inherited 83 acres, a "shack" under a big elm tree, and proud stories of Jackson Morgan settling the virgin land. Freedmen in the area had helped each other to clear the land and burn the brush, then planted their first survival crops of sweet potatoes in the burned places. As Walter said, "We call it giving each other strength, some people call it backboning, strengthening my brother." ${ }^{20}$ Having little farming equipment or work stock, Jackson Morgan and his freedmen neighbors used light wooden plows to put in their first crops of corn and cotton. Some families lacked even this and worked their first fields entirely with hoes. ${ }^{21}$

\section{The Bachelor Lifestyle of Doll Fort}

Some of the whites who lived in the vicinity of the Thomas family possessed little more than they did in the way of acreages and farmhouses. One of these was John W. "Doll” Fort, an elderly bachelor, who like the Thomases also lived on an approximately 100-acre fragment of a much larger farm inherited from his family. Young Dean Fort of McDade often visited his greatuncle Doll on his farm near Scott Falls, and Dean well remembered this independent loner and life-long bachelor who lived a nineteenthcentury frontier lifestyle until the government forcefully took his land away in 1942. There were other people like Doll Fort on the north Bastrop sandylands - sometimes whole families. Dean said of his great uncle:

He was a big man, and he was kind of a harsh man, but he was a good man. He never married, he lived alone over there. I used to ride my bicycle over and spend weekends with him. I'd gather eggs for him, and he'd make us a cake or pie. He could cook about as good as any woman could cook. Sandy Creek run down below his place, and I used to go down there and catch perch and bring 'em back, and he'd clean 'em and cook 'em for us. ${ }^{22}$

Doll Fort lived in a small board-and-batten frame house with a porch across the front. For his necessary cash, which was not much, Doll raised corn, watermelons, cantaloupes, and (in the past) a little cotton, and during Prohibition he made a good bit of excellent "bootleg homebrew." Doll's private wagon trace ran north to the public Scott Falls Road through deep sand almost impassible to automobiles, but people usually had to seek Doll out to purchase his melons or beer. The old bachelor seldom went into town and disliked spending the night away from his place. ${ }^{23}$ 
Doll Fort chose a life of personal freedom and minimum needs - a small house, small garden, two or three milk cows, and a few hogs and chickens. One man living by himself did not require a lot of such things. Dean enjoyed spending days at a time at Uncle Doll's house, and Dean thought the old man enjoyed his company, but circumstances were not overly stimulating. Doll might sit all morning on his porch and say very little to the young visitor; he was not into idle chit-chat. "He'd sit there, and he may spend three or four hours and never say over half a dozen words." At daylight Uncle Doll would get

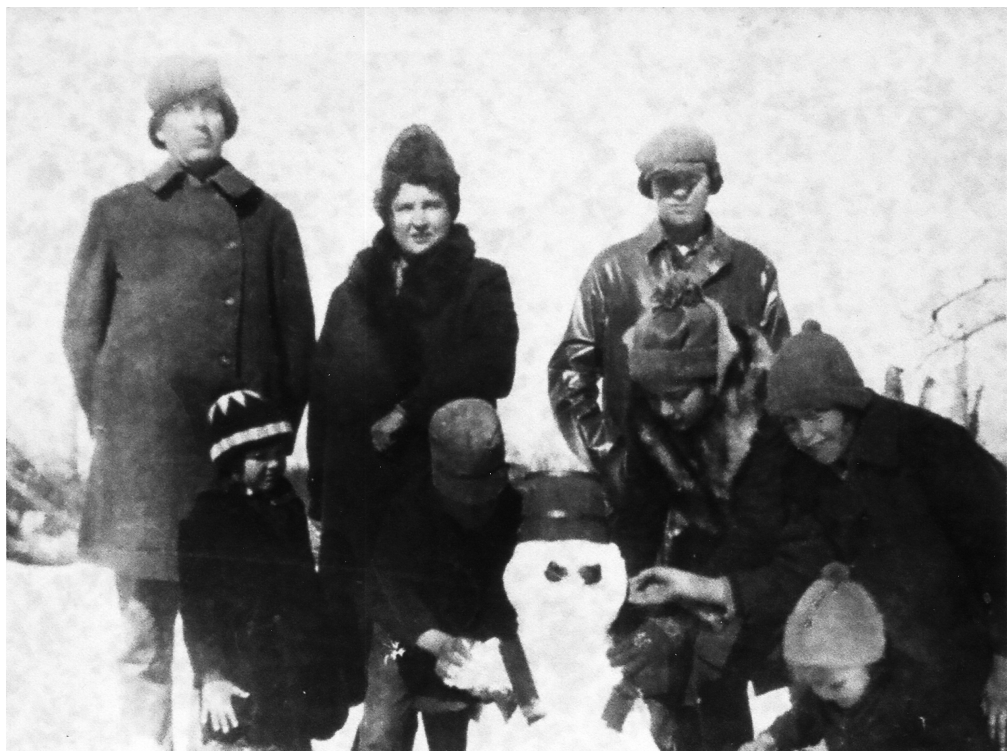

Figure 3-10. Robert W. Smith, Bertie Hancock Smith, and their six children, 1929-1930 (Ruth E. Smith). Left to right (rear): Robert Smith (father), Bertie Hancock Smith (mother), and Woodrow Smith; center: Gertrude Smith, Kenneth Smith, Ruth E. Smith, and Amy Smith; front right: Bonnie Smith. up, fix breakfast, then sit on the

porch thinking his own thoughts "just about all day until come time to eat and he got hungry, and he'd go and fix something to eat. He made cornbread and biscuits just as good as anybody else could." Dean assumed Doll sat on his porch and thought, since "there was nothing to look at but trees, oak trees and cedar, that was all." ${ }^{24}$

In his chosen life of solitude, personal freedom, and frugality, Doll Fort did some things that no wife would have tolerated. For example:

he chewed the old Day's Worth Chewing Tobacco in a plug. And he'd get him a big cut of it and chew it until he chewed all the juice out of it. And his house had wooden windows, and he'd lay it up on the windowsill and let it dry. And once it dried, he crumbled it up and smoked it in his pipe. You'd go out to his house, and there'd be two or three plugs of chewing tobacco drying on the window sill. $^{25}$

\section{Water}

When asked to describe in general the physical circumstances of the farmhouses where they grew up, many people soon turned to a discussion of the water problem. Creeks, springs, and wells often ran dry on the Bastrop sandylands, and families like that of Ruth E. Smith, who had a cold, deep well that never failed, even in the terrible drought year of 1925, truly gave thanks (Figure 3-10). ${ }^{26}$ Evelyn Cottle's family also regarded themselves as fortunate, although to supplement a leaky cistern they had to haul household water from an excellent and well-known spring several hundred yards from their home. The spring had a wonderful clean taste, something that could not be said for most cistern water and for some well water. People sometimes asked Evelyn's father for permission to fill a barrel from his historic spring, which had been "rocked up" to deepen its pool. Most years (but not all), Albert Cottle allowed this. ${ }^{27}$ 
Other families had inadequate household water nearby and hauled it in barrels from somewhere else by horse- or mule-powered wagon or "slide." Slides were crude wooden sleds that skidded over the surface of the ground. Bettye Blackwell's father Willie Blackwell did this, transporting well water long distances from a friendly black neighbor's house. The Blackwells had a cistern, but Willie disliked and distrusted cistern water, at least for drinking purposes. ${ }^{28} \mathrm{O}$ L Flowers also hauled many a barrel of water on a sledlike contraption dragged behind a mule, "and sometimes the road gets kind of rough and the old mule wouldn't do right and turn that barrel over and have to go back and get another one." 29

No wonder then, that families regarded household water as a valuable resource and practiced strict water discipline. Not only did they not waste any water, but they recycled water from one use to another. The Blackwell family's stock pond went dry in 1936, so twice a day they drove milk cows and other work stock to a water source on black neighbor Green Taylor's place. "Late in the evening they would be lowing for water, it was so dusty and they bellowed all the way," Bettye Blackwell remembered:

Water was a precious item around our house and never a drop wasted. Water from the wash pan was poured on Mama's flowers, and water from our baths from a tin tub was used to scrub floors and then put around the flowers or poured in the hole the dogs would lay in to try and stay cool.

As did most families, the Blackwells limited tub baths to once a week, although "even with the lack of water we were clean people." During the week "we only got to wash our private parts from a wash pan and to use lye soap or $P \& G$ Soap." ${ }^{30}$
At Morris J. Kastner's home, tin cisterns and an underground cistern caught water from the roofs of house and barn - at least if it rained. The Kastner family also practiced strict water discipline and recycled daily dishwater as a component of "hog slop." Family members bathed in succession in the same tub of water once a week, and water set aside for hand washing lasted for several days. "You didn't waste any water back then," Morris explained. "If a rat or something got in your cistern, and it died in there, you just dipped it out, got rid of that rat. But you kept your water and you used it." ${ }^{31}$

A few homes were better made, more comfortable, and stood out from the rest, and often this showed up in water luxuries. With a barrel and scaffold, Jack Scott's grandfather had arranged an outdoor shower at his house, although one had to fill the barrel with buckets of cold well water. ${ }^{32}$ At the Oak Hill community, JoNell Hancock's house had running water from the cistern to the kitchen. ${ }^{33}$

\section{The Daily Round of Chores}

When his helpful great-nephew was not around, Doll Fort picked up his own chicken eggs and did the other necessary chores on his minimalist farming operation. Other farms on the sandylands were far more complicated. From age six or thereabouts, every child in the farm family had to contribute to the daily round of farmwork by performing certain compulsory tasks - "chores," the daily work that must not fail. Cows had to be milked, water to be drawn, wood hauled inside to feed the voracious stove, and corn fed to work stock, swine, and several varieties of domestic fowl. Inside the house, someone toiled to cook at least two hot meals a day on the wood stove. Chores literally lasted from dark to dark on the family farm, and 
no wonder that hard-working young Morris Kastner, whose father had died young, recalled rest in bed at night as his best memory of the countryside. Morris's widowed mother and her children labored at the subsistence side of their farm, while four sharecropper families on the place raised the cotton and other cash crops. ${ }^{34}$

Assuming that both parents lived, a farm child's experience of the farming life depended on the number of brothers or sisters and his or her position in the birth order. The child's allotment of chores might be light or heavy, housework or fieldwork, based entirely on matters beyond his or her control. Heavy burdens usually fell upon the first born, especially the oldest son, as they did on Abner Scott, born to Grover and Ina Fay Scott in 1923. Grover often left for days at a time to build wooden derricks in the Luling Oil Field, so early on Abner assumed responsibilities on the Scott farm. ${ }^{35}$

$\mathrm{S} \mathrm{T}$ and $\mathrm{O} \mathrm{L}$ Flowers were the only children of Shirley and Pallie Flowers, African American renters of the Frank Dennison place just east of Sayers, and the brothers split the hard labor for this family's short-handed farming operations. The Flowers family raised enough corn and cotton to satisfy their landlord, paying him one third of the corn and one fourth of the cotton as rent for his place. These payments were known as thirds-andfourths. As a sideline (or perhaps a mainline), they kept cows, hogs, chickens, and turkeys, planted a big garden, and grew sandyland field crops of sweet potatoes, peanuts, syrup cane, field peas, and watermelons. Landlord Dennison did not expect or receive any portion of these things. Older brother S T took the lead with his family's cash crops; certainly he was the one that usually accompanied his father to go "picking on the prairies," gathering other farmers' cotton on the Blackland Prairie after the Flowers' own skimpy sandyland cotton had been ginned. Meanwhile, brother O L stayed home and served as his mother's right-hand man with the many labors of the subsistence side of the farm. O L did not mind this home duty, since above all things he hated to pick cotton. By their teenage years, the well-known Flowers brothers often hired themselves out as day laborers to surrounding white farmers, thus bringing in additional income for the family. ${ }^{36}$

While children's allocation of chores depended both on their sex and their place in the birth order, the latter was most important. First-born girls often had to help their fathers and mothers in heavy field work. Later, as more children joined the family work force, the oldest girls led by example in fieldwork and took on the additional responsibility of supervising their younger brothers and sisters; they became "overseers" of the necessary, but somewhat erratic, child labor. ${ }^{37}$ Furthermore, they had to care for those children too young to help with the work (Figure 3-11).

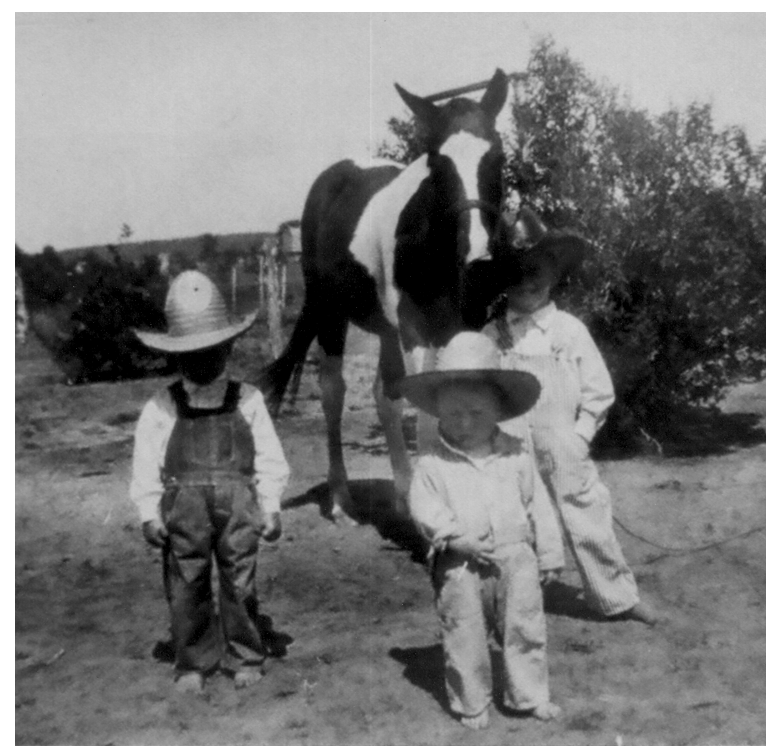

Figure 3-11. Billy, Jimmy, and Jerry Fleming with horses, late 1930s (Jonathan Fleming). 
In short, first-born girls often had to be "made the boy," as rural people sometimes stated the matter. African American Mary Lou Reese explained her situation:

I was the oldest kid in the [Reese] family. I was the boy in my family, cause I was the oldest. Papa had me up on those cane stacks and hauling fodder. Cutting them tops! My sister and I, we'd get out there early in the morning. We done downed all them corn tops, put them over there, little boys come by and tie them up. We'd stack it, have a pole standing up there. Papa, he didn't have no big boys, so I had to stack fodder. ${ }^{38}$

As the years went by, some of Mary Lou's duties involved supervising her younger brothers when they worked at some task, such as picking cotton on other people's farms. Nobody enjoyed picking cotton, especially if your parents got all the money for your hard work, and from time to time Mary Lou had to resort to "stirring 'em up a little bit" with a switch. Sisterly discipline worked up to a point, but then the young males began to rebel:

I had a little brother...He would get under a cotton stalk and sing, he loved to sing. Oh, he was a songster! He would get down there wasn't doing nothing, just rustling and shaking bushes, and I'd have to stir him up a little bit. One day he told me, 'Now, listen, I ain't no kid no more.' He wasn't taking a switching. ${ }^{39}$

The hard fieldwork and the additional duties of babysitter and labor organizer for rebellious siblings wore on oldest children like Mary Lou. "I said [to my sister], 'I'll be so glad when I get away from here!' What a life, and what a blessing to grow up." ${ }^{\prime 4}$

Mary Lou's white friend Fay Owen drew a quite different set of chores on her family farm, also based on her sex and place in the birth order. Fay had two younger brothers and two older brothers, so she did not often have to join in field work. Instead, Fay helped her mother and "was washing dishes when I had to stand on the chair to reach the dishpan." ${ }^{41}$ Chore-wise, Fay drew all the housework help, including dish washing, house cleaning, clothes washing, and ironing, and she also served as assistant cook. Generally, Fay did not mind this role as mother's sole female assistant, but she noted that her brothers split the boys' chores four ways and so often seemed to have more leisure time than she did. ${ }^{42}$

Friday washdays required heavy labor in the back yard. Big iron pots had to be filled with water and fires built under them. Dirty clothes had to be boiled in the pots, scrubbed clean on rub boards, rinsed in two or more rinse-water tubs, then hung out to dry on clothes lines, bushes or barbed-wire fences. That was not the end of the relentless, weekly clothes labor, as Fay told:

The work clothes was always last to go through the wash, and with a big family it was a heavy chore. And as I got older, my Saturday morning chore was ironing. The irons had to be heated on the wood cook stove, and I had to iron all our clothes. All the boys shirts, all our school clothes for the week, I had to iron 'em. It took all Saturday morning for me to iron those clothes, but that was my Saturday morning chore. ${ }^{43}$

One task especially vexed Fay when she came to it: the tiresome ironing of oldest brother Andrew's starched white linen pants so he could wear them to the house party of his choice for that weekend. Linen was hard to iron and easily scorched, and Fay sometimes resented playing the role of drudge sister for the playboy brother. ${ }^{44}$ 
Farmwives like Fay's mother Elgitha needed all the help they could get. As historian Rebecca Sharpless's research (and our own interviews from Bastrop County) attests, farmwives labored at a daunting triple role of housewife and mother, field hand, and manager of the complicated subsistence side of the farm..$^{45}$ It varied with circumstances, but farmwives on the sandylands generally had to do a good bit of field work while somehow managing household duties. Bettye Blackwell's mother took her younger children to the field to play nearby, since there was no babysitter at home. Bettye recalled of this typical situation:

Mama always worked in the field with Daddy and would come to the house at eleven to put on dinner. She would wash the pinto beans and put them on to simmer to finish up when she got back to the house. If it was summer time, she would send me to the house to put another stick of wood in the stove and a tablespoon of salt and also two tablespoons of bacon grease - my first cooking. Then she would make fresh cornbread. We could not have survived without pinto beans and cornbread. ${ }^{46}$

\section{Down-Home Cooking}

Many other families said much the same; pinto beans, cornbread, and milk were their daily fare. May Belle Miller Morriss was born next to last in a family of eight boys and four girls. Sally Benight Miller, her mother, died of tuberculoses at age 42 in 1925, when May Belle was seven years old. The motherless Millers had it hard, with the older kids, by necessity, taking up the slack. Food, as at other sandyland homes, consisted mostly of pinto beans, cornbread, dairy products, sweet potatoes, and garden vegetables consumed straight from the garden - "down-home cooking" with an air of desperation about it. Aside from the readilydried pinto beans, field peas, and corn, little food preservation went on because the family tended to "eat things up," even the pork from the smokehouse. A whole ham might be consumed by the Millers at a single meal. ${ }^{47}$

By May Belle's late childhood years, several siblings shared the family's cooking chores, including one brother. The family "raised everything to eat except the flour and sugar and shortening. My dad had a yearround garden, and my brothers cut firewood and hauled it nine miles down to Bastrop for \$2 a load." The firewood money bought the necessary flour, sugar, and shortening, but everything else came from the place. Sweet potatoes and peanuts served as fall-back foods that - no matter how tired you got of eating them - staved off any real hunger. Like many families, the Millers put sweet potatoes in the oven of the stove as a matter of course while they cooked other things, then kept the baked potatoes around as a mealtime staple and between-meals snack. "My Dad raised sweet potatoes," May Belle said, "he'd fill that stove full of potatoes and bake them." 48

The Millers got up at four in the morning every day to "milk the cows and then feed everything and then go to the fields before it got too hot." Before leaving for the fields, but after the early chores, they sat down at a long table for a typical breakfast - always, without fail, biscuits and syrup, and occasionally, eggs and bacon also. "Every morning we cooked biscuits. I tell you, I didn't know there was light bread in the world." At noon the family trooped in from the field to reassemble for dinner around the long table, and, although one or twice a week pork or chicken showed up on the table, workday fare was mostly cornbread and beans. "Usually cooked pinto beans, a pot every day, cause that's what it took, that's what we had to eat on. We didn't have a lot 
of different things to eat like they have now." Beans and cornbread were washed down with the milk from one or more of the five cows kept by the Millers - this many needed "since they don't all have milk right along." ${ }^{49}$

Since people "didn't have a lot of things to eat like they do now," they tended to eat certain foods a great deal, and some former country dwellers entered the twenty-first century with a profound aversion to pinto beans, field peas, canned corn, or even biscuits and syrup. A large can of syrup, sorghum or ribbon cane, usually sat on every "eatin' table" at every meal. Others remained fond of the rural survival foods of yesteryear. For example, Fay Owen noted, “Boy, I ate many a parch peanut when I was a kid, and I loved them." ${ }^{50}$

Gertrude Dunkin Barton recalled the down-home cooking of her mother, Garland Huff Dunkin, with a certain nostalgia. Of the family's general circumstances, Gertrude noted: "We just lived off the land, we didn't have any money. And bought very little from the store - coffee and sugar and flour and salt, that's about it. We had a wagon and the best pair of mules in the country. We had a good life. We were poor, but everybody was poor." Of her mother's cooking, she said: "She made the best biscuits and cornbread, we didn't know what a loaf of bread was." Garland cooked fresh blackeyed peas in a three-legged iron pot, adding fresh-cut okra right at the end. When field corn reached the "roasting" or "milk" stage (just before full maturity, when kernels release a milky liquid), she harvested a few ears. She baked the cut-off field corn with milk and butter as a sort of corn custard. Sweet potatoes baked, peanuts roasted, and dried corn parched in the big wood stove whenever Garland fired it up. Gertrude remembered that she and her brothers and sisters would: ...get us a potato and stick peanuts in that and eat it. And my mother canned, oh, she canned all summer long. In the winter we had everything was canned. We liked the food that she cooked. She made it good out of nothing. She never wasted a crumb. She'd keep the biscuits left over, and then she'd make us a big thing with beat-up eggs. I think she'd get vanilla extract and then milk and sugar and poured it over those biscuits and put it in the oven. It was good. ${ }^{51}$

Bettye Blackwell's family ate beans, cornbread, milk, and sweet potatoes. When the family ate meat, "We mostly ate squirrel, rabbit and pork. Chickens were always kept for meat and eggs and if we would get company unexpectedly." Many an evening meal (never cooked on the stove) was just cornbread, sweet milk, and perhaps a cold sweet potato. Food was generally plentiful for the Blackwells, but "mostly the same things always." 52

"Waste-not, want-not" ruled country cooking, as it did so many other aspects of life. Little was wasted, and Bettye observed the darker side of these food practices at her Grandmother Blackwell's kitchen. She noted much use of left-over fat to make "long gravy" to "stretch things" and have something to "sop your biscuits in." Grandmother Blackwell's cooking was fat and gravy, gravy and fat, with biscuits abounding, and required a lot of sopping.

For breakfast she would fry some fat bacon and some eggs and then pour all the grease over it and naturally have a big pan of biscuits, and they would eat all the grease and there would not be a drop left. They killed Grandpa Blackwell with kindness and grease. He had a bad heart trouble and I guess his veins were filled with fat. They would eat this at night also, and lots of molasses and grease. ${ }^{53}$ 


\section{The Subsistence Side of Life}

Despite relentless frugality and recycling, every family needed to arrange a minimal cash flow from crops, agricultural day labor for others, or "public work," occasional work at some outside job in the oil field, brick plant, lignite mine, or elsewhere. To a remarkable degree, however, farmers on the north Bastrop sandylands stayed home and practiced an older farming style they summed up as "living on the place." The many complicated details of this practice dominated our interviews with former residents of north Bastrop County.

While farms on the Blackland Prairie to the north evolved toward agribusiness during the 1910s and 1920s, farms on the sandylands remained primarily subsistence-based. Daily meat and bread still came from hogs in the pen and corn in the field. Farmers then, as now, felt proud of this great self reliance, of making do with what they raised and made themselves, but they also felt somewhat defensive about the hand-to-mouth nature of it. Jack Scott told his interviewer in 2004: "You had to do everything yourself because there wasn't none of this bought stuff around here because we didn't have money to buy it with. You asked me for the truth and I'm telling you!" 54 When cash flow from whatever source declined to a mere trickle during the Depression 1930s, eating out of the garden became even more important. One woman recalled that "I hated to even ask my daddy for a nickel, cause I didn't know if he had it or not." 55

The farming operations of the Anglo American Owen family at Oak Hill and the African American Flowers family east of Sayers resembled each other and typified those of many other area families. Both family farms required many words to describe and explain.
The Owens owned their farm, and the Flowers family rented theirs on the thirds-and-fourths, but this made little difference in their lifestyles. Both families had their ways of generating the necessary minimums of cash, but both devoted much time to subsistence farming.

\section{Home Gardens}

Asked what their mothers and female relatives had raised in their respective gardens, Fay Owen and O L Flowers seemed hard-pressed to remember it all. Both mothers had spring and fall gardens and raised many different vegetables. Fay's aunt, Polly Owen, had 29 kinds of vegetables in her garden. ${ }^{56}$ Fay's mother Elgitha Owen cultivated, among other things, tomatoes, green beans, squash, cucumbers, beets, cabbages, and Irish potatoes. Roasting corn for family consumption came from the field, as did sweet potatoes and black-eyed peas. Both families ate fresh produce from their spring and fall gardens from the first early lettuce and radishes to the last pumpkins and winter squash. $\mathrm{O}$ L summed up his mother's garden in words that served equally well for Elgitha: "Mama had a garden. Everything she planted in the garden we eat or some of it we canned up - everything that look like was going to waste, she'd take it and can it and put in a jar and set it up for the winter." ${ }^{57}$ Likewise, Gertrude Dunkin told of her mother's garden:

It was huge. All Daddy did was plow the garden, Mama planted all the stuff. They had a big wire fence around the garden, and stuff was always growing up the fence. English peas, fresh English peas, and okra. I mean, well, name it and she had it in the garden. She had all kinds of turnips, big turnips, squash and tomatoes and okra. Butter beans, pinto beans, green beans, you name it. And we saved everything that we could dry. ${ }^{58}$ 
People commonly reckoned their mothers' gardens at two acres or larger. And beyond the gardens proper at many homes lay the various "patches," vegetables or fruits grown separately in massed rows, a half-acre at a time - patches of cabbage, Irish potatoes, sweet potatoes, peanuts, blackberries, and other edibles (Figure 3-12). They might also cultivate one or two fruit trees (Figure 3-13), or sometimes entire orchards. Not all the patches were for growing food, however. Both mothers and daughters might also have a flower garden (Figure 3-14).

Farther out still than the patches lay the field crops grown for family use, which in the sandylands, depending on how well they grew in a particular season, often became cash crops as well: field peas, peanuts, pumpkins, various melons, and the master crop of corn. Families sold these field crops, even the corn, when they produced beyond what the family could use themselves or give away. "We grew watermelons, cantaloupes, and peanuts and sweet potatoes," Morris Kastner explained. "You'd plant so many, and then whatever you didn't need you'd sell" or give away to neighbors. "Everybody kind of helped one another, back then," ${ }^{59}$ Morris concluded, noting the gifts of excess food crops to neighbors who then invariably reciprocated with some of their crops - though probably not then and there, the illusion of a pure gift thus politely maintained. Irish potatoes and sweet potatoes, for example, did not usually grow well in the same soil, so

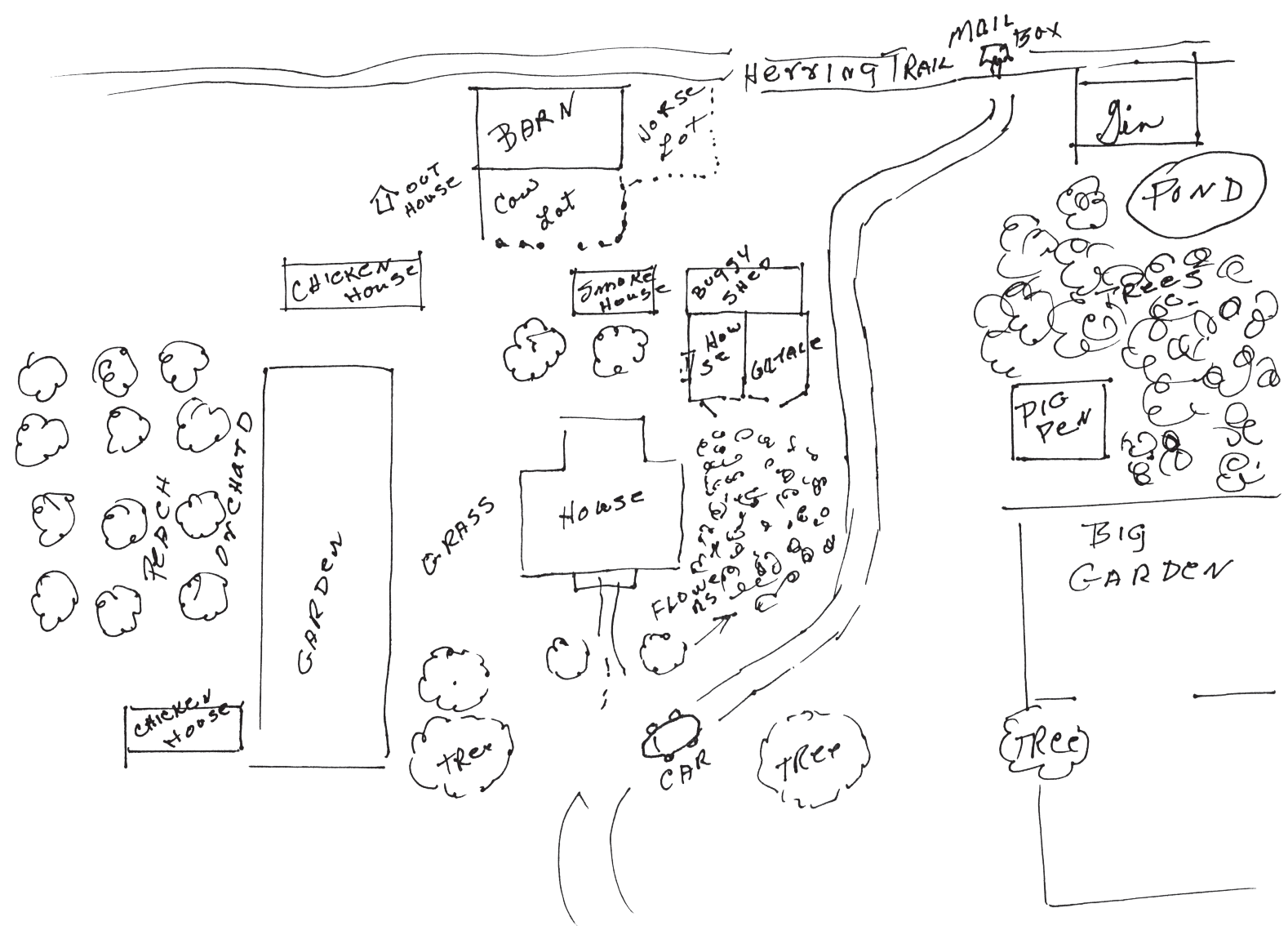

Figure 3-12. Plan of the Arthur Hancock homeplace showing the large garden and various patches (JoNell Hancock Majors). 


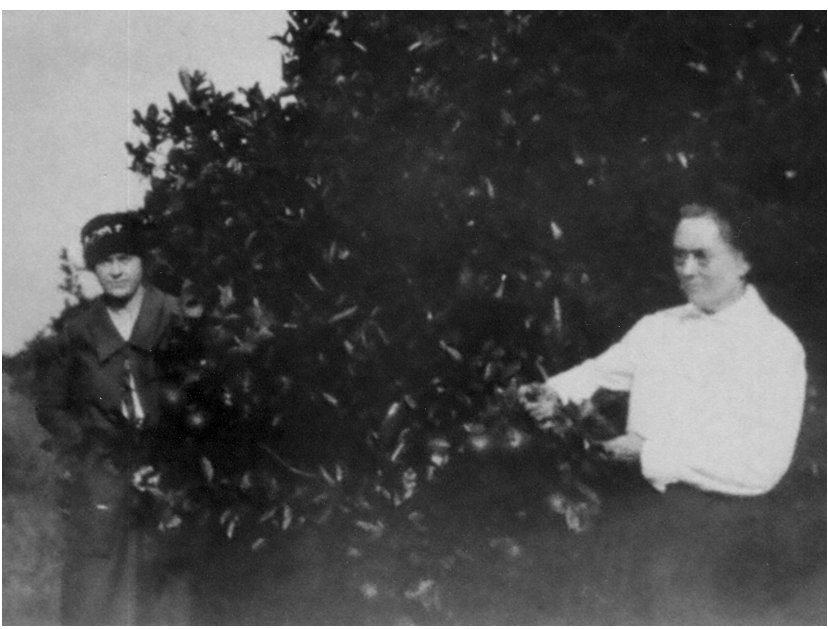

Figure 3-13. Sue Smith and her mother Edith Mae Smith by a lemon tree, date unknown (Louise Smith Goerlitz).

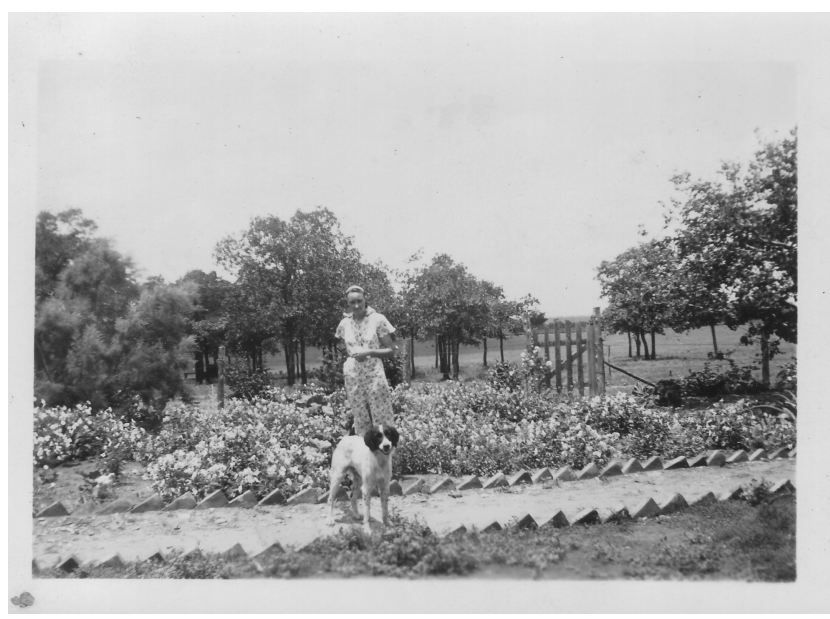

Figure 3-14. Fay Owen in her flower garden at Oak Hill, 1938 (Fay Owen Pannell).

a wagonload for a wagonload between distant families composed one classic Southern food swap that was much appreciated by both sides.

\section{Sweet Potato Cultivation and Storage}

Sweet potatoes prospered on the Bastrop sandylands. Virtually every family raised at least a large patch of them, and in a normal year they produced abundantly from a small area of ground. On a calories-per-square-foot basis, sweet potatoes could not be beaten. They were thus both a key subsistence field crop for sandyland farmers and, in a good year, a cash crop as well.

May Belle Miller's large family planted both sweet potatoes and Irish potatoes, but the Millers consumed all that they raised. They cut up Irish potatoes and dropped them along a groove in the top of a row, "eyes up," then covered them with dirt. Sweet potatoes grew better and were even more important to this family of thirteen. May Belle's father would go down the row punching holes with his walking stick, while his children followed behind planting the holes with sweet potato "slips" that were previously nurtured in hotbeds, "and then it'd take hold and start living and running and making potatoes underneath". ${ }^{60}$ Most crops grew out in the open where you could see them, but sweet potatoes maintained an element of mystery. They grew out of sight in the dark ground (which is why people preferred to plant them "in the dark of the moon"), and one did not know exactly what was down there until the turning plow dug them up in October.

The Flowers family sometimes planted as much as two acres of sweet potatoes, though they rarely sold any. If the sweet potatoes "made," the family knew they would not go hungry between that crop year and the next, no matter what disasters fell upon the cotton or watermelons. The Flowers family sprouted sweet potato slips in well-manured hotbeds, then set them out in rows. "Sometime we take a hand and push them in the ground, sometime we take a stick to push them in the ground, put a little dirt around them." ${ }^{11}$

The rows of sweet potatoes began rather flat, since the Flowers family planned to add dirt to them. After the little plants set roots and began 
to grow, $\mathrm{O} \mathrm{L}$ cultivated up the middles with a single mule and light sweep plow, throwing dirt to the plants on the rows to each side of the middle. He added dirt to keep the sweet potatoes from forming tubers too deep in the ground. Potatoes grown too deep might attract weevils or be damaged by the big turning plow at harvest time. As $\mathrm{O} \mathrm{L}$ explained, the fall harvest first required the removal of the vines, thickly coiled over the ground in every direction. "After that sweet potato grows, it makes a long vine. We had one mule and what we call a slide, it had knives on the top of it - slide it down through there and cut them vines, then they'd be away from the row." After that they returned to the potato patch with two mules and a turning plow to turn each row over and:

throw them potatoes out to the top of the ground. Then we'd come along behind them with a basket, put them in a wagon, and take them to the house and pile them up. Get some corn stalks and set them up like that [making a teepee shape with his hands] and then kind of plat them around that stob, and then your dirt, fill all that up with dirt. And that's where we keep them in that during the winter. Have a little trap door there where we could go in, stick our hands in there, and get sweet potatoes out during the winter to eat. That's the way we kiln them for the winter. ${ }^{62}$

A good many local farmers continued to use the temporary corn-stalk sweet potato storage "kiln" or "bank" described by O L. You could hardly store two acres of potatoes in one, but you could easily make as many banks as you needed. They cost nothing, and materials to build them were close at hand. For each one, you mounded up a bed of soft sand three or four inches above the ground, nested your potatoes lightly in the sand (close, but not touching), made a teepee of corn stalks overhead for a roof (leaving a hole on the side to get your hand in later, perhaps covered with a piece of bark), then finished the teepee roof with a layer of straw and a layer of dirt. Such a storage shelter not only insulated the sweet potatoes from damaging frost but also shed rain water.

Rather often, a stranger passing on the road might see an array of little corn-stalk teepees spread across the back yard of a sandyland farm. The potato bank was one of the nineteenthcentury lifeways still in use on the Bastrop sandylands, akin to the occasional employment of oxen as plow stock. Other families stored their potatoes on tarps in the open crawl spaces under their houses, prepared a place for them in the barns, or-like Grover Scott's family at the Scott log cabin place - kept them in a special brick sweet potato cellar in the farmyard. ${ }^{63}$

\section{Field Peas}

Southern farmers, especially those that lived on sandy soils, grew and consumed a lot of field peas, also called cowpeas. ${ }^{64}$ People's stomachs might turn when they saw them once again on their eating tables, but they often rejoiced to get them. Farmers often grew peas interspersed in the corn-sometimes, as with the Grover Scott family, a row of peas every third row in the field, sometimes peas planted in the middles between the corn rows at time of last cultivation. ${ }^{65}$ Field peas were as close to a "no-fail" crop as local farmers grew. Even during the terrible drought year of 1925, when almost all of the corn died, field peas often still managed to make some kind of a crop. Black-eyed, whipperwill, crowder, zipper, lady slipper, purple hull — field peas had many names, and farmers did not always know just what sorts grew in their fields. But they grew, even in the "sugar sand" country of the Alum Creek drainage north of Highway 21, where only loblolly pines seemed to prosper. Field peas flourished on the poorest of sandyland 
soils. Only the most impossible soil drew the Southern dirt farmers' ultimate condemnation, "that land's too poor to sprout nameless peas."

Farm children walked through the fields in late autumn harvesting dried field pea pods into cotton sacks. Back at the house, they jumped on the sacks and pummeled them with sticks until, by sound and texture, they knew most peas had been shattered from their dried pods. Then, on a day of high wind, someone stood on the back of a wagon and slowly poured the contents of each cotton sack to a tarp on the ground. Peas fell to the tarp, while pod fragments blew away to the side. Families stored their field peas in several-gallon metal cans, fortified against weevils with a sprinkling of Hi-Life (a commercial pesticide or bug deterrent), snuff, or perhaps a silver spoon.

\section{Food Preservation}

Below-ground storage of sweet potatoes was a cutting-edge agricultural practice. Families struggled to preserve the food grown in the home gardens and fields. The county farm agents and county home demonstration agents, white and "colored," of the Texas Agricultural Extension Service (TAEX) were abroad in the countryside during the 1920s and 1930s teaching new and better methods of food preservation - principally, "hot bath" canning - and they found a ready audience, especially among the farmwives. Their husbands sometimes felt less enthusiastic about hearing a "book farmer" county agent tell them how to grow cotton or watermelons.

Not only did the Grover Scott family build a state-of-the-art sweet potato storage cellar, but Ina Scott put on community canning demonstrations for the county agent at her home. Many things from Ina's two-acre garden were preserved in Number 2 cans, but the two great favorites for canning were tomatoes and field corn harvested in the milk stage. County agents preached the "one hundred cans a year" doctrine for each of these crops, and many farmwives enthusiastically joined in. Oak Hill community leader and volunteer Polly Owen worked as a community assistant for the Bastrop County Home Demonstration Agent for twentyfive years, and she practiced what she preached. Polly and Edgar had no children, but she still put up one hundred cans of several different things every year. Niece Fay recalled going over to help process the hundred cans of tomatoes, which took all of one day. Despite her lack of mouths to feed, "Aunt Polly always had a big garden and canned everything."

Neighborly corn canning, in particular, often turned into an all-day social affair. Men of the household often joined into these mass cannings of tomatoes and corn, and neighbor women came over to help in the kitchen. Later, the canner would help with her guests' cannings. Men got the green ear corn in from the field, shucked it and "silked it," and then the women took over. Sharp knives passed over each ear twice, assuring no whole grains survived. After a while, errant corn fragments spattered the person and surroundings of the knife user, but that was to be expected. Women then packed the cut corn into cans or jars and cooked and sterilized it in boiling water on the stove. People had always enjoyed the brief roasting phase the field corn passed through each crop season, but now you could have this tasty sweet corn all year.

Abner Scott offered a male participant's point of view on these corn cannings. In his opinion, "the work was not the cookin' and everything, it was the picking it and cleaning it, shelling it, whatever. We'd shuck that corn and silk it. That's a job to get the silk off all of it. Mama would cut it off and can it." ${ }^{97}$ 
County home demonstration agents used several hands-on techniques. They held howto demonstrations of up-to-date practices, as with the Scott canning, and they announced model facilities that community people could visit and examine. For example, Abner Scott's Grandmother Scott had an TAEX-approved model kitchen and Evelyn Cottle's mother a model pantry, with shelves on three sides absolutely lined with cans and jars. Polly Owen once reported on this wonderful pantry in her Oak Hill column for the Bastrop Advertiser, telling exactly how many jars were in it. ${ }^{68}$ Farmwives without pantries stored canned goods in their smokehouses or lined the walls of the rooms of their homes with them, often stacked several jars deep.

County agents had preached to the choir in the waste-not, want-not countryside, and local housewives joined canning programs with an almost religious intensity. For insurance, they canned more than their families actually needed and enough to give away. They canned to prevent the waste of any garden vegetable, and they canned to socialize with the neighbors. In the cannings, rug makings, mattress makings, and other social affairs, TAEX agents cleverly linked their home improvement programs to older communal work traditions, such as quiltings, goose pluckings, fence buildings, log rollings, and the like. O L Flowers often helped his mother with community-wide cannings in the Sayers vicinity, affairs organized by the "colored home demonstration agent." Many communities, black and white, constructed special canning centers, but in this case canners used the kitchens of derelict houses:

They did a lot of that, they did a lot of canning. Somebody'd kill a beef, and a bunch of the community would get together and buy up a bunch of cans. And then they'd go to these old abandoned houses, they had a stove in there, and they'd cook that meat and can there. And I'd have to go along with them, me and Mama went to might near everything that went on. And then I'd help seal them cans. ${ }^{69}$

By 1920, food preservation had attained high technology with the advent of the hot-bath canner and pressure cooker, but older air-dry methods of preservation still sufficed for the key crops of field peas, peanuts, and Indian corn. Peanuts were dug up, piled around poles in "ricks" or "shocks" in the field to dry (kernels turned out), hauled by wagon to the barn, and stored for use as animal fodder and human food. Cows, hogs, and other stock relished both kernels and "peanut hay," the upper part of the plant. Peas, corn, and pinto beans (the latter usually grown in the garden) could simply be allowed to dry in the field in their shells or shucks, then harvested and stored.

\section{A Corn-Fed Menagerie}

Corn also dried to maturity in the field, each ear of grain encased in its water-shedding shucks. Indian corn was the master crop for the sandyland farmers of north Bastrop County, the crop that must not fail. Corn provided the daily bread for humans, fed virtually all the domestic animals on the place (Figure 3-15), and fueled the work stock for their hard labors. Farm families breathed a sigh of relief in mid-summer whenever ears of corn in their fields matured enough to ensure a crop. Rare years when rains failed and corn died young, as in 1925, brought total disaster. County agents helped some black families butcher their milk cows in the fall of 1925 , since they had nothing to sustain the cows through the winter. ${ }^{70}$

Renters like the Flowers family gave onethird of their corn to their landowners as partial rent for use of the land. The farmer usually 


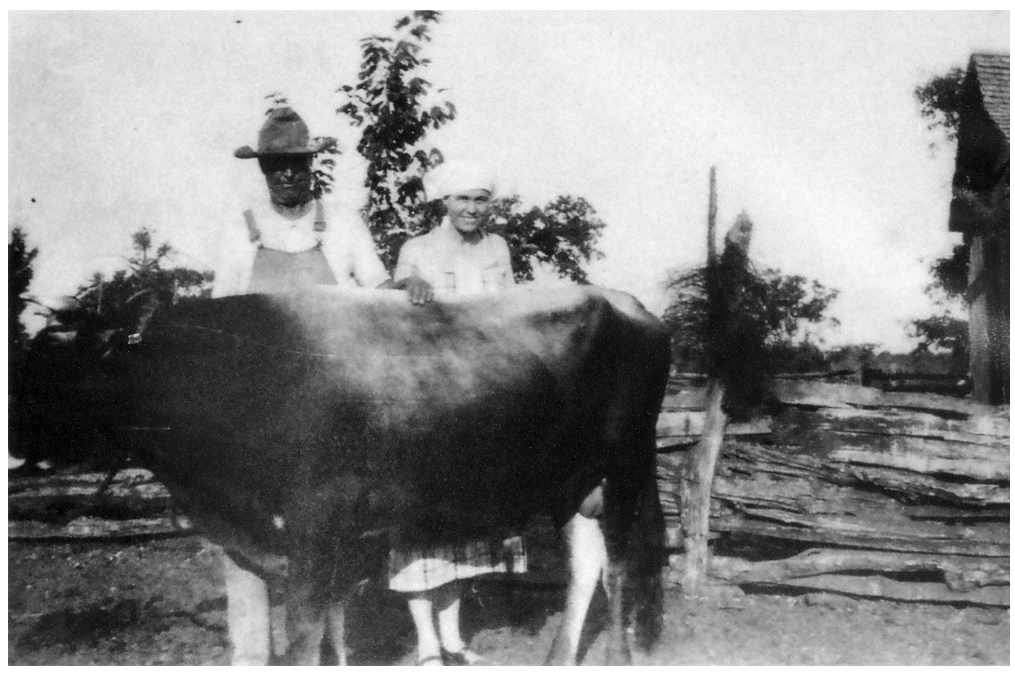

Figure 3-15. Andrew Morgan Smith and daughter Sue poise with prize bull, "Westgate," date unknown (Louise Smith Goerlitz). county agents noted that little corn went in the ground on a waning moon. Furthermore they planted thickly down the rows and expected to "chop," or thin, later. Farmers always overplanted; "One for the cutworm, one for the crow, one for the blackbird, and one to grow," was the cautious old saying. When a "packing rain" dried to form a crust on the sandy ground, new corn shoots could not penetrate to grow. Corn that was prevented from breaking the sandy ground, or that was killed or blighted by a cold snap, calculated this by informal wagon load, two wagons to the family's corn crib followed by one to the landowner's. The Flowers family always made sure they raised enough corn to end up with plenty of their own. ${ }^{71}$ Families who owned their land sold some corn but tended to be conservative. Most felt they needed several wagon loads for use on their own farms every year. They did not want to run short, and they could never be sure about next year's crop. Historians of classic nineteenth-century Southern cotton and corn agriculture have paid the most attention to the money crop of cotton, but it was corn that sustained the subsistence side of life on the farm. The subsistence side was extremely important, and nowhere was this so true as on the sandylands.

In truth, to understand life in the Southern countryside at places like northern Bastrop County one needs to follow the corn. Farmers carefully hand shelled each year's seed corn from the best ears of last year's crop. With walking and riding planters, they planted corn early, often with an eye to the signs of the Zodiac and the stages of the moon. Farmers might scoff publicly at belief in "the signs," but quickly brought walking or riding planters back into the field. You had to have corn.

Use of the corn crop began when the plants were half grown. Old varieties of corn often put up side shoots called "suckers," and farmers cut these as green fodder for cows and work stock. By the first week of July in most years, ears of corn reached the full-size milk or roasting stage, and families harvested their fields for ears of fresh corn for roasting and canning. A tasty kind of soft sweet bread also could be made from the milk corn after grating it. People desperate for real cornbread and out of last season's corn crop might harvest ears of milk corn and dry it on a tin roof.

At the late milk stage, while the corn began its long drying in the field, but before the plants began to turn brown, farmers cut corn tops to store for winter forage - a major use of the corn. Many farm families also stored peanuts - gathering nuts, plants and all, for forage - and most gathered wild bluestem field hay, baling it with laborous mule-powered hay balers or stacking it medieval-style around tall 
poles, but almost all gathered and stored corn tops. Milk cows and work stock both loved corn tops.

Families entered their corn fields by night and went down the rows cutting the tops of each plant just above the uppermost ear of corn. Each worker accumulated an armful of cut tops, tied them up in a bundle with another corn top, then left it behind in the long line of bundles down a middle. Night harvest ensured that corn tops were sufficiently moist and flexible to be used to tie up the bundles of other tops, but tradition played a part also. While it was cooler at night, workers could not see the occasional snakes and other varmints encountered in the corn. Bundles of corn tops lay in the field to dry for a certain number of days. These were gathered to the edge of the corn field in piles, then were hauled by wagon to the barn and carefully stacked in big slanting conical piles around tall support poles, ready for fall and winter use. To feed stock, people pulled tangles of wellcured corn tops from the inside of the conical stack with long hooks (as they did hay from the haystack), while the stack gradually collapsed around the pole.

Corn harvest, called "pulling corn," came in autumn sometime before what Erhard Goerlitz called "hog turning-out time." 72 Few people minded pulling corn as much as picking cotton. Farm families usually went through the corn field in wagons, throwing in ears of corn from rows on each side. Someone, often a younger child, picked the ears from the row of corn the mule wagon knocked down with its passage, the unpleasant task termed "pulling the down row." Corn often stood in the field drying for months while the family harvested more perishable cash crops. Vines and weeds grew up, and insects moved in. One year, the Blackwell family's corn had attracted so many stinging scorpions that they harvested by night, when the scorpions seemed less active. ${ }^{73}$ Mule-powered corn harvesting also had its drawbacks, as Mary Lou Reese recalled; at corn harvest time, mules labored in a field of tempting mule food:

Just depends on how big the field was. Sometimes it's too much trouble to have a wagon and mules. They trying to eat, you have to muzzle them, keep them from eating. So, Dovie [her sister] and I would go out there and pull these corn and go down the row and put them in the pile, then we'd go back with the wagon and pick them up. Papa could help us load, but he wouldn't always. Sister and I were the boys of the family. ${ }^{74}$

In general, use of work stock "wasn't like just turning a key," as one man laconically explained. ${ }^{75}$ The farmer's power source was another living being, and often a contrary one, at that (Figure 3-16). One of Grover Scott's mules so feared crossing bridges that it once crowded

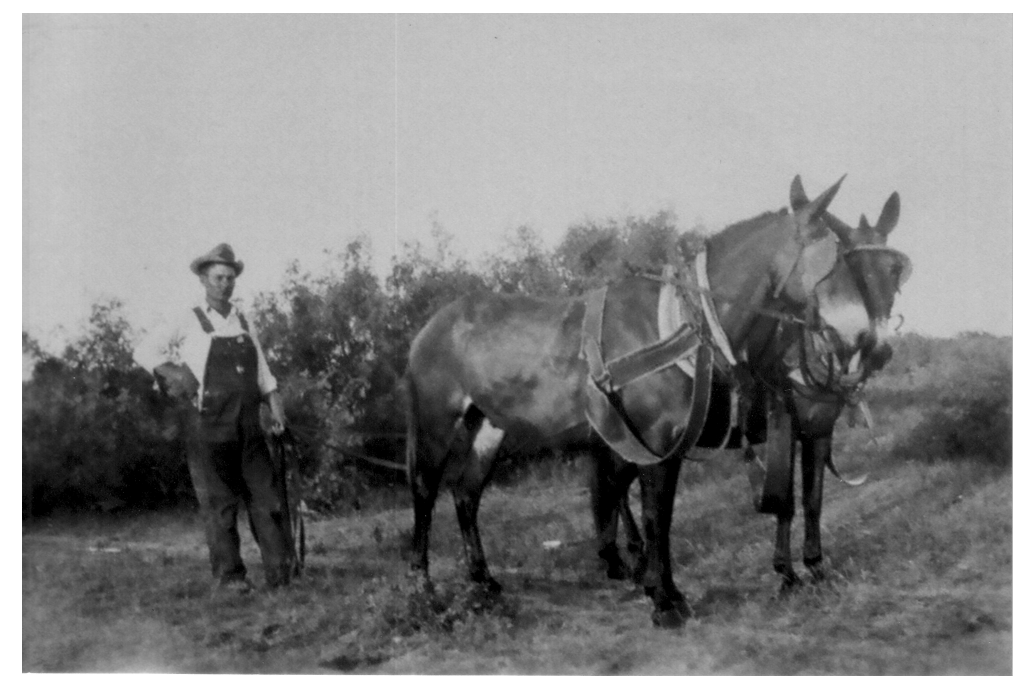

Figure 3-16. Otis Evans with work stock, late 1920s (Jonathan Fleming). 
its harness-mate off the opposite side of a low bridge into Big Sandy Creek, creating a horrible scene. ${ }^{76}$ The Blackwell family's mules Kit and Tobe normally hung around the barn - until they detected that you planned to make use of them. Then, they ran to "the back of the place," and when you went there, they returned to the barn. Bettye Blackwell recalled, "After a couple of times of this, Daddy would fill his shotgun shell with peas and shoot them, and they would go right in the pen." ${ }^{\text {7 }}$

Three to six wagonloads of ear corn, stored in its shucks in the family's corn crib, usually sufficed for the year, although the family fed corn to mules, horses, cows, hogs, chickens, ducks, geese, guineas, turkeys, as well as to themselves. Southerners ate Indian corn in every way conceivable and often twice a day. The oldest uses of dried field corn required no grinding for meal, and some still favored them. Irene Fleming's mother often made lye hominy in a big black pot in the yard, and Irene noted that "we've eaten many a pot of hominy." 78 Shelled corn might also be added to the peanuts and sweet potatoes roasting in the back of the iron wood stove while other things cooked, thus producing the old time survival (and traveling) staple of "parched corn." 79

Corn for human consumption (and for domestic fowl) needed to be shelled almost on a daily basis, and Fay Owen and others recalled the chore of processing ear after ear of shucked corn into the top of a corn sheller. Fay or one of her brothers would jam a ear into the top opening of the sheller, which was firmly clamped to the side of a rough table or horizontal shelf (usually in the barn), then forcefully turned the handle to noisily shatter grains from corncob. ${ }^{80}$ Families knew almost to the ear how much corn they needed to shell for a weekly supply of cornmeal, and once a week or so some family member took a sack of shelled corn to the nearest grist mill, which by 1920 was often operated as a sideline at a steam- or diesel-powered cotton gin. Often on Saturday mornings, while their sisters perhaps toiled over hot irons back at home like Fay, lucky boys rode horse or mule to the nearest mill with a cotton sack of shelled corn across their saddles. The miller charged a toll for his services, usually one-eighth of the meal. Someone always had to go for the cornmeal. Once, when the Blackwell family's Model T had broken down, Bettye remembered her father hoisting corn sack to shoulder and setting out on foot for the nearest grist mill at McDade. ${ }^{81}$

Back at the farm, people cooked the fresh cornmeal in a variety of ways, with the oldest methods involving the open fireplace. One such technique was corn mush cooked in a threelegged dutch oven. Stiff corn batter might be spread on the blade of a big cotton hoe and held close to the coals to make a traditional hoecake-a sort of nineteenth-century fast food. Or, stiff batter might be cooked into ashcakes, as Annie Hardin recalled her grandmother doing. ${ }^{82}$ By 1920, however, most local housewives and their assistants baked the family's daily cornbread in the woodstove oven - sometimes in "pone pans," more often in a round iron skillet or shallow baking pan. They let the cornbread cool a little, then dumped the round cake onto a serving plate and cut it into wedges. As at the Blackwell home, cornbread (left over from noon) and cows' milk sufficed for many families' evening meals, especially in the hot summers. ${ }^{83}$

The cows that provided the beverage for the Blackwells' supper also had fed on corn in the form of green corn suckers from the field, corn top fodder, corn shucks, and quartered or halved ears of corn on the cob. Fragmented ears of corn and small undersized ears, "nubbins," 
sustained cows, hogs, and the work stock of horses, mules, and oxen. Without the cornpowered work stock, nothing much got done on these sandyland farms, which were short of tractors (and of automobiles, especially during the Depression years).

\section{Hogs}

Every family kept hogs to provide pork for the smokehouse after hog-killing time in the late fall. The hogs fed on corn and nearly everything else. They were the ultimate consumers of the corn-centered farm. Wastenot, want-not practices often ended up in the "hog slop." Even if a family had free-range hogs that scavenged for earthworms and acorns in the woods, it always kept some hogs close to partake of feedings of corn and hog slop, which might contain any leftover food, spoiled food, and usually the daily dishwater. Families with excess cow's milk (and that was most of them) hung the milk in bags to drip whey and gradually curdle in the bag. Curded milk helped feed chickens and turkeys, while whey and any excess curds went into the hog slop.

Pork dominated the menu on the north Bastrop sandylands, as at other places across the South. When local people said "meat," they normally meant flesh of the swine. Eggs and turkeys tended to be sold in town, chickens usually were reserved for company and special occasions, and beef was an unusual delicacy (and in any case could not be easily preserved). Meat tended to be hog flesh, and people ate a great deal of it.

Bastrop County had a stock law from the 1880 s, and virtually all farms had perimeter fences with cattle enclosed by 1900 , but hogs passed freely through barbed-wire fences, and hog husbandry largely depended upon local custom. As long as hogs stayed off the major highways, the sheriff did not intrude. According to early accounts, the first settlers at the Oak Hill community around the time of the Civil War named their community in appreciation of its abundant acorns, the basic wild foodstuff depended upon to fatten free-range swine. Jonathan Fleming's oral tradition of his greatgrandmother Fleming came from the latter days of this time:

They said of Mama Fleming, 'she worked like a man.' She always took her a snort of that Levi Garrett [snuff], stuck a stem of bluestem grass in her mouth, put a Derringer in her apron and a bonnet on, and she'd light out in them sand hills four five six hours at a time to gather them hogs up. ${ }^{84}$

Nor was Mama Fleming alone. In parts of the 87 square miles that were less densely settled, especially in the sand hills of the Alum Creek drainage on the southeast, perhaps as late as the 1930s some families let their hogs run out all year, as in southeast Texas. ${ }^{85}$ Dean Fort well summarized the essential practices of the old Southern free-range tradition. Hogs "ran out" most of the time, freely ranging across different people's land. "Once a year, they'd round 'em up [with dogs], sell some of 'em, and they would mark the ears so they would know who they belonged to. And that's when they'd turn 'em loose again, cause if they kept 'em up, they had to feed 'em. This way they hustled their own food." 86

By 1920 or so, however, in more densely settled parts of northern Bastrop County, a seasonal free range for hogs had become the custom. Farmers kept the potentially cropdestroying hogs behind hog-proof fencing until October 15, when all crops were assumed to be in. Then they opened their gates. Hogs roamed at large for some weeks after "hog turning-out time" and before "hog-killing time," fattening 
themselves for free on acorns and other fall mast. People slaughtered all they needed for meat after the first strong cold snap of November, but survivors roamed on through the winter until about February 15, a week or so before the first crops went in the ground.$^{87}$ Some farmers, living in closer circumstances, better off, or perhaps more committed to modern livestock practices, kept their hogs in pens and hog pastures year round. ${ }^{88}$

Agricultural reformers disliked the customary free range. A friend of the county agents, Polly Owen critically noted in her Oak Hill column that she just had seen far too many swine still running out in the local woods and badly in need of butchering. ${ }^{89}$ However, as perhaps Polly well knew, these were probably seed stock awaiting their customary spring penning up.

A few farmers still preferred the taste of acorn-fattened pork, but most now penned the animals up for some time before their executions and plied them with corn. Corn-fed hogs tasted better, many people thought, and farmers wished to fatten them for the kill. Hogs provided two critical resources for the farm family, meat for the smokehouse and lard for cooking. Dean Fort's father never butchered a hog until it reached around 500 pounds in weight, and such hogs provided much fat. "He'd get ten to fifteen gallons of hog lard out of it, and that's what Mama cooked with," Dean remembered. "So, we never bought any grease." ${ }^{\prime 0}$

Rural children (most of our interviewees were children or adolescents before 1942) had considerable experience with life and death on the farm, and perhaps had wrung many a chicken's neck, but hog killing was animal butchery on a grand scale. Blood, excitement, and feasting burned hog-killing day into people's memories. Large families usually killed several hogs each year, and across the Bastrop sandylands people went about the process very much the same. A good strong norther in November triggered hog killing, and across the north Bastrop countryside many swine died on the same day. Other farmers might consider the sign of the Zodiac and the stage of the moon and wait for the next norther. Opinions differed about "the signs." Pork killed on the waning moon often waned away to nothing in the cooking pan, some believed. ${ }^{91}$

On many farms the doomed hogs were brought out, given a little corn to fix their attention, then shot or knocked in the head. Butchers hung them up with throats cut for half an hour to "bleed out," then took them down for scraping. They dipped small hogs in barrels of scalding water set halfway in the ground, then pulled them onto boards for scraping. Butchers placed larger hogs, too big for the barrels, on boards, then scalded and scraped off their bristles one section at a time. Now startlingly clean and pink, hogs were hung heads down from single trees or scaffolds for gutting and initial butchering. Getting the hog hanging perfectly straight made butchering go easily, many people thought. The butcher used an ax to cut bones, as well as a big knife. Sections of the hog then were laid on a table and cut into scrap meat for sausage, fat for lard, and meat sections - bacons, hams, and shoulders - intended for the smokehouse. People ground sausage meat, mixed it in a clean washtub with seasoning until cooked test patties of the fresh meat tasted just right, stuffed it into hog intestines that women had cleaned and scraped thin, and hung it in the smokehouse. Women rendered the valuable hog fat into lard and stored it in big crocks. Hog butchers packed meat destined for the smokehouse in salt or soaked it in brine for a few days, laid it out to dry, then hung it in the smokehouse 
(Figure 3-17) over a slow fire, often for weeks. The Goerlitzes liked their pork "good and dry," so they smoked it a long time. Erhardt Goerlitz told, "You took it out and hung it up, then you smoked it with hickory, and when you walked by that smokehouse it smelled so good you could almost eat the boards." 92

Most families chose not to wait for weeks to sample their pork. Hog-killing participants often feasted at the end of the day on special delicacies of the butchering, including more fresh-mixed, pan-fried sausage, liver, and brains. "My mother always took out the brains and scrambled eggs with them," Irene Fleming said, "and we thought that was a delicious thing to eat." 93

Very occasionally, a farm child only reluctantly participated in the epic events and gourmet delights of hog-killing day. Young Leola Blackwell had been allowed to "claim a pig" by her father. "You know, to play with," Leola explained. "They make beautiful pets,

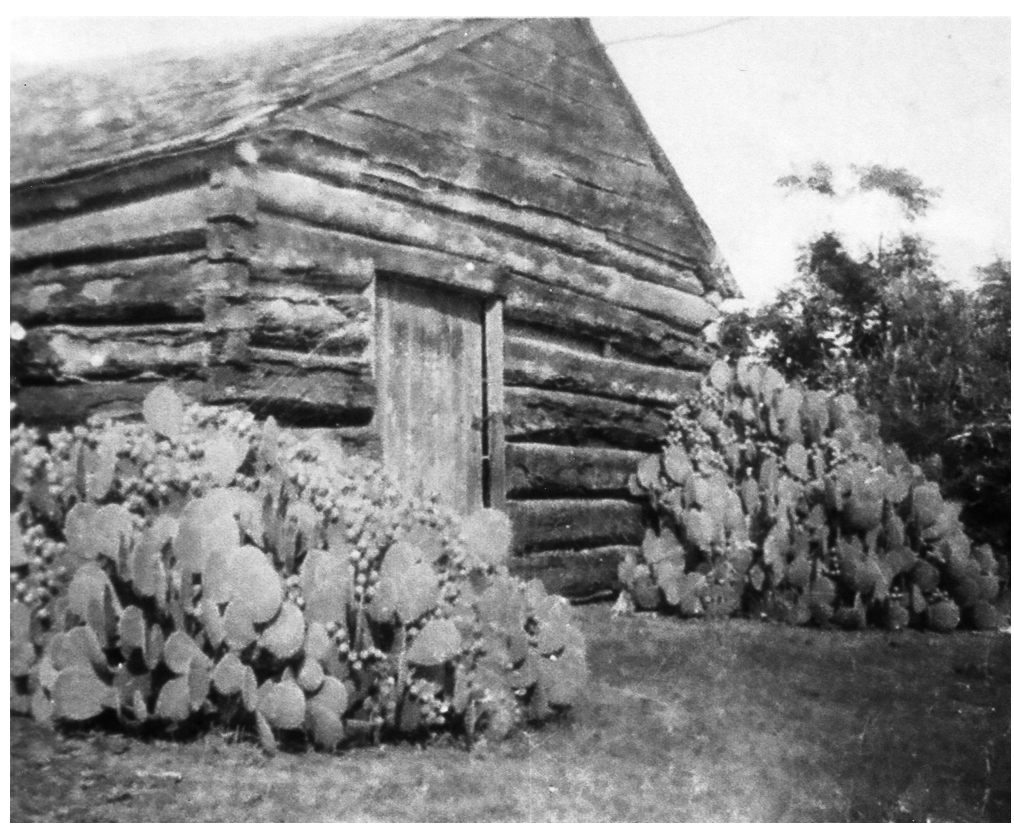

Figure 3-17. Smokehouse at the rear of the Hancock house in Oak Hill, date unknown (Ruth E. Smith). they're sweet animals. When you're with them all the time they follow you like a dog. And I always picked the least one, and I could play with it and enjoy it 'till it come time to eat it, I guess."94

Bloody, memorable hog-killing day often became a social occasion, with relatives or neighbors coming over to help and often taking home fresh meat. Jack Scott came out from McDade to lend a hand at his grandfather's place. His grandparents, John and Minnie Lea Scott, killed several hogs for themselves and their town relatives who were enduring hard times in the Great Depression. ${ }^{95}$ At the Hancock farm at Oak Hill, as JoNell Hancock recalled, "Black folks in the community would come and help because he [Arthur Hancock] would give them part of the pork." 96 Sometimes the blacks butchered their own hogs and shared with the neighbors. Mary Lou Reese recalled of the Reese family's memorable hog-killing day:

Hogs, we had hogs, and how! We'd try to kill enough hogs to have meat. Mama'd cure the hams that we didn't eat right now and smoke it in the smokehouse. Kill three or four hogs, you know, and away Mama'd send us to neighbors to deliver it, take it over there to them. Cause, I think we were the biggest neighbor down there, had more family, and we always shared. And wheneverthey'd come through with their killing, why, they'd share back, but it wouldn't be like what Mama would send. She was free-hearted. ${ }^{97}$

\section{Farm Fowl}

Corn fattened the hogs for hog-killing time and often constituted their last meals on 
earth. Careful doles of corn and shattered corn kernels, "corn chops," also tied a variety of other domestic animals to the farm. Chickens, turkeys, geese, ducks, and guineas roosted at or near the farmhouse, received feedings of corn in the evening and mornings, then roamed out during the day to forage for the other food they needed. The trick was to give these varieties of useful fowl just enough corn to keep them around but not enough to dampen their spirit of initiative. "Yard chickens," for example, were expected to spend their days scavenging for insects and other things in the yard. "Grasshopper turkeys" needed to hunt grasshoppers in the pasture and acorns, pecans, and mustang grapes from much farther afield. Daily handouts of corn were the tether for all these semi-feral fowl, supplemented by occasional feedings of milo maize, field peas, dried milk curds, and other things.

Pallie Flowers kept chickens, turkeys, guineas, and ducks. ${ }^{98}$ Not much use was made of the latter two domestic birds, but some people still liked to have them around the place. Guineas - African peafowl - ranged the farm like wild things. Guineas had dark meat, so few liked to eat them. They laid their small eggs in hidden nests along the fence rows, but farm families already had all the chicken eggs they could use. Guineas had their use, however; they remained ever vigilant. If a fox or a skunk or a prowler came by at night, they invariably gave the distinctive clattering alarm. According to May Belle Miller, these "little speckled things make a lot of noise, they would be good as a watch dog." guinea, he's more wild, he's kind of like a watch dog. Whenever you hear a guinea cutting up, there's something or another around there."100

Only a few families still kept geese by 1920 , but geese also had their uses. German Texans loved to serve roast goose on Christmas Day.
Bettye Blackwell's “Aunt Margaret kept the geese for their feathers, and a couple of times a year she took the down feathers" for stuffing feather beds and their accompanying pillows. Geese were irascible things, however, as young Bettye discovered when one of her aunt's geese attacked her in the outdoor pit toilet. ${ }^{101}$

Chickens were far more important, and every farm had some, usually in excess of what the family needed for meat and eggs. Some families let them run half-wild and roost in trees. Others provided kerosene-heated chicken brooders and elaborate hen houses (see Figure 3-5). ${ }^{102}$ Families ate chickens from time to time, often on Sundays when they had visitors or on special occasions, but chicken eggs had become a dayto-day commodity, readily convertible to cash. Most of the families of the people interviewed sold eggs to the nearest store on a weekly basis. As Morris Kastner explained, usually on Friday or Saturday "we'd sell our eggs at the store there [in McDade], and my mother would buy groceries or whatever we needed. Back then you could buy a whole lot of groceries for just a few dollars." The weekly egg sale kept the Kastners (and almost every other family) in ready cash for coffee, flour, kerosene, and other staples not produced on the place. ${ }^{103}$

\section{Cane Syrup}

Coffee was bought with eggs that came from chickens that fed on corn. Other basic foods on the farm had nothing to do with corn but might complement it on the table. What was cornbread (or biscuits), for example, without syrup to pour on it? A container of sorghum or ribbon cane syrup stood on every table at every meal, and families usually consumed prodigious amounts of syrup. People occasionally mentioned forty to fifty gallons as an average adequate annual syrup ration for a large family. ${ }^{104}$ As did most 
families, the Flowers family raised a patch of "molasses cane" beside the peanuts, sweet potatoes, and other food crops, and O L Flowers clearly described the cane growing and syrupmaking process:

We planted them [the cane] just like you was going to plant cane for feed, but the stalks was different from the feed stalks that we fed to animals. They'd grow to about six to eight foot, maybe sometimes ten foot, tall. Then we'd get in there with what you call a cane knife and strip it, strip all the leaves off of it. Then we'd go back and cut it down and load it on a wagon and take it to a mill. Lay it down up aside the mill, and they had a mule going around and around pulling the molasses mill. They'd lay the cane in there, then they had a deal that come along and squeezed the juice out of it, and they'd catch that juice in a bucket, and then after they got so much they'd put it in a pot and cook it, and that's when they'd make molasses. ${ }^{105}$

The syrup maker in this case was Edward "Tobe" Clark, who made syrup near his own cane fields at a remote location close to the confluence of McLaughlin and Big Sandy creeks. Other farm families, white and black, also brought their cane to Tobe Clark, despite the difficulties of getting to his place. Good syrup cooks were at a premium. The deep-sandy road down to Clark's place on the creek sometimes meant the Flowers family had to hitch up all four of their mules to the wagon to get the cane to the site. Abner Scott took the family cane to Clark on one occasion, then found himself put to work feeding the cane into the cane mill himself; Tobe Clark must have been short-handed that day. ${ }^{106}$

By 1920 syrup makers normally used a compartmented pan, copper or galvanized steel, to cook syrup from raw juice in a continuous process. Juice from the mule-powered cane mill went in at one end, was pushed along as it cooked through various compartments of the pan (while the "skimmer man" skimmed off scum and impurities), then exited the cooking pan as finished syrup through a faucet-like tap at the other end. O L Flowers recalled that other local syrup makers (probably including Green Taylor) still used a simpler and much older method. Such a syrup cook poured multiple buckets of cane juice into a large black iron pot, then cooked one batch of syrup at a time. ${ }^{107}$

A syrup maker like Tobe Clark used his eyes and nose just like a cook in the kitchen. Of the process, O L Flowers noted, "They'd stir it and watch it, and every once in awhile they'd hold it up and let it run and look at the color of it, and in a certain length of time you could cook it and make different colors." Clark made "custom syrup," with each man's cane processed separately. "So, he could ask each one, 'Well, what do you think about this? Think it's about right, about like you want it?' Said, 'Naw, I believe it ought to be a little bit more.' Well, he'd cook it a little longer."108

Clark tested both color and consistency of the syrup as he cooked it, dripping it off a wooden spoon. Then, after his customer expressed satisfaction, Clark ladled it into containers, keeping only his rightful share of the product. Customers often took the syrup home in whatever containers they had, then poured it into their syrup barrel or barrels back at the house. ${ }^{109}$

Older ways and skills, passed down from the century before, also made contributions to living on the place. Willie Blackwell raised no cane for syrup and was in some ways an improvident man. His family tended to "play out" of things - gasoline for the Model T, matches to light the fires, and even stove wood 
in mid-winter - but Willie often filled the gaps with old-time skills. The Blackwells' storebought syrup was supplemented with wild honey. Willie was a bee-courser and honeytree-raider. $\mathrm{He}$ baited bees with sweetened water at the local stock tank, watched them carefully, then followed their beeline to their home tree and gathered honey by the bucket full. ${ }^{110}$

\section{Hunting}

Willie hunted with dogs for sport with other men, but he also hunted to put meat on the family's eating table. Bettye Blackwell recalled that "We mostly ate squirrel, rabbit and pork." 111 The big game of frontier times, white tailed deer, wild turkey, and black bears, all had disappeared from "Bear Strap" County by 1920, but much small game remained. These included opossums, coons, squirrels, rabbits, and the nine-banded armadillos that some people, joking about what they had to eat during the Depression, called "Hoover hogs."

Cottontail rabbits and jackrabbits were all too common, farmers thought, since the sandylands had diversified away from cotton. Rabbits disdained to eat young cotton plants but loved the taste of sweet potato and melon vines. Farmers reduced their numbers with festive Saturday afternoon rabbit drives, hunted them by night with shotguns sitting on the front fenders of slowly-driven cars and trucks, and put out poisoned sweet potatoes for them in the melon field, but they also killed many rabbits and other small animals for the pot. Grover Scott provided his oldest son Abner with a single-shot .22 rifle and told him to spend his spare time hunting squirrels in the family's pecan orchard along Big Sandy Creek, and Abner happily did so. The idea was both to preserve pecans (which the family sold) and to provide the raw materials for tasty squirrel stew. ${ }^{112}$ Erhard Goerlitz summed things up in these words:

"I'll tell you one thing about the Depression. Big families, as a rule, they usually kept one of 'em in the woods hunting squirrels and rabbits. And man, if it hadn't been for all them squirrels and rabbits, hell, these people would have starved to death. That ain't no lie! And when your old man sent you out to the woods, he wanted production when you shot that shell." 113

\section{Gathering Wild Plants}

Louise Smith's family not only sent someone to the woods with a .22 rifle, but like many other people in north Bastrop County, they also made use of a wide variety of wild plant foods. The Smiths walked the creek bottoms picking up pecans and hickory nuts, and in their various seasons they gathered poke salad and other wild greens, wild onions, dewberries, blackberries, wild plums, huckleberries or high-bush blueberries, and two varieties of wild grapes. ${ }^{114}$ Earlier, perhaps even more wild plant foods had been utilized. The late Annie Hardin, born around 1890, mentioned some of the same foods as Louise but added blackhaws, hackberries, and bull nettle seeds to the list. ${ }^{115}$ Certainly, the self-taught, and sometimes uncannily effective, "herb doctors" and "root doctors" had been more numerous in nineteenth-century times.

Berries and grapes especially abounded on the north Bastrop sandylands. Families like that of Mary Lou Reese picked dewberries "by the tubful" and sold them by the gallon in town or by the roadside. Some customers even drove over from Austin to get them. Dewberries made wonderful fresh pies, and they could be canned for pie fillings for the rest of the year. ${ }^{116}$ Several varieties of grape vines produced even more abundantly. People normally distinguished between the opossum or fox, post oak, and 
mustang grapes. The latter covered many trees in the woods, and upon occasion could turn a whole tree blue-black with grapes. You could gather these by the wagon load, if you knew what to do with them. A promising wine industry in the area, successfully begun on Big Sandy Creek by French emigrant and vinticulture pioneer Antoine Aussiloux, had died with National Prohibition in 1919, but wild grapevines grew as well as always. ${ }^{117}$ The Smith family gathered both post oak grapes and the more common mustang grapes and used them to make jelly or juice. "Them old mustangs, they would burn your mouth," Louise recalled, and they also tended to act on the hands of grape processors like dilute sulfuric acid. Families picked grapes, heated them in big pots to cook and soften, mashed them in a sack to force out the juice, and stored the concentrated unsweetened juice in sealed jars. Then, "Weaken it with water, put some sugar in it, and it was a pretty good drink." 118

Other people had different designs on the wild grape juice. During the long dry years of National Prohibition, a good many local people made crocks of mustang and post oak grape wine for private consumption, and some even sold wine commercially, though you might have to visit them discreetly at their homes to purchase it. ${ }^{119}$

\section{Natural Medicines and Home Remedies}

Most families also gathered, cooked, and consumed the wild green called "poke salad," though poke as a plant food merged over into home medical care, another aspect of living on the place outside of the money economy and far from towns and doctors. Poke salad loved sandy soils, and its tender spinach-tasting stalks and leaves grew abundantly every year from long-lived poisonous roots. Left ungathered, it grew higher than a man's head and produced poisonous berries. People picked tender young poke salad in the spring but seemed nervous about it. They boiled poke greens three or more times, pouring off the water each time, before they ate it. Some scrambled poke with eggs, others poured hot pepper sauce on it, and most added hog lard or bacon grease to the cooking pot. A good dose of hog fat seemed to exorcize the poke demons. Mary Lou Reese recalled:

We grew up with poke salad. It's like spinach, but I think they say its kind of a poison...When I cooks it, I put in some fried meat grease. I think that'll cut the poison...Got to put the grease to it, and that why I say I can eat some but I can't eat a whole bunch. It's too greasy, too much grease. ${ }^{120}$

Families who otherwise ate little poke salad often gathered one "mess" in the spring and consumed it as a purgative, "to clean you out." Poke thus fell into the large category of substances used as preventative medicine to give the sluggish bowels of winter a big jumpstart into the new season. Children in particular needed this cleaning out, many parents and grandparents believed. Willie Blackwell stood each of his children in turn in the back door of the family's farmhouse and administered a generous tablespoon of a patent medicine called Black Draught, and it certainly did its job. His daughter Bettye Blackwell said, "Daddy was a firm believer that your body needed a good working out every spring." Poke salad also worked you out and got you ready for the hot weather, people believed, and perhaps with one or more "pour offs" of water omitted from the cooking process it did just that. Willie Blackwell's mother clearly thought of poke salad as part of the ritual purifications of spring, both of graves and of bowels. She summoned Willie every spring to take her to the Mt. Bethel Cemetery on Piney Creek to clean her father and mother Smith's graves, then on the way home 
she had him stop and pick her a mess of poke to clean her own insides. "It was supposed to be a blood purifier," Bettye recalled. "Grandma was raised on that creek, and I guess when they were trying to hang on to their land, after eating cornbread and molasses all winter, those greens tasted pretty good." 121

When Abner Scott's younger brother Dan drank a glass of kerosene, also called "coal oil" (kept around to start the woodstove), his father Grover Scott rushed him to the doctor at Elgin; Dan, much chastened and emphatically cleaned out, survived. For many lesser medical emergencies, up to and including concussion, snakebite, child birth, and work stock kicks, rural people stayed home and tried to heal themselves. Taking care of oneself and one's family was part of living on the place, and doctors in 1920 had not yet achieved the godlike eminence they attained later on. For one thing, they had failed to cure the 1918 flu. Families treated themselves with wild plants, patent medicines, and such common household liquids as whisky, bluing, turpentine, and coal oil, the fluid young Dan Scott over-dosed on.

Typical home remedies at the Blackwell farm included soaking in kerosene for nail puncture (or snakebite), a teaspoon of sugar with three or four drops of kerosene for cough, Vicks Vapor Rub massaged into the neck for a sore throat or the chest for a head cold, and so on. Some families favored remedies based around the active ingredient of coal oil, other families favored the use of turpentine, and still others preferred newfangled gasoline. ${ }^{122}$ People also commonly used medicinal whisky, but this had become hard to obtain legally.

Families also used wild plants for their home remedies, sometimes quite effectively. Children went barefooted except in wintertime, and they often developed minor risens, boils, stone bruises, and splinter infections on their bare feet. For risens and splinters, the Blackwells burned the thorns off a prickly pear lobe, split it, and bound the cactus pulp to the skin with a cloth. They sometimes also used a piece of fatty hog meat in much the same way. ${ }^{123}$

Basically, poor people just crossed their fingers and hoped nothing bad would happen to them or theirs. The family of Ruby Mae Thomas Johnson and her brother Walter Thomas, both interviewed in this project, lived in the deep countryside near Big Sandy Creek, and the only medicine in the Thomas household was Watkins Liniment. Ruby Mae recalled her mother's loving use of this patent medicine: "Mama could cure you with it, Mama had healing hands, cause she could just rub you, and it look like the pain would go away." Parents always hoped that nothing really serious would befall their children, but occasionally it did. A rattlesnake bit Ruby Mae's older brother while they were fishing on the creek. The children did not know what to do, and were looking for the snake to kill it, when Mr. Scott came by. "God took care of us, Mr. Scott came by, he said, 'What's wrong with that boy?' We had him laying out side of the road." Mr. Scott made the snake-bitten brother to lie with his leg in the cold water of the creek and sent for the local "doctor man," who gave the boy "green stuff" to make him vomit and placed a polstice on the bite. "My brother laid out for days," while the family poured cold well water on his leg. Finally, it began to turn back to a more normal color: "and we didn't have to take his leg off. But you know, it was just amazing how God healed us down there without a doctor. Down there it was kind of like in the wilderness." $" 24$

The Thomases were a poor black family and could not afford a costly town physician, 
but the Thomas children recalled their white neighbors being little better off. ${ }^{125}$ In any case, families often tried to heal their own. After Irene Fleming's brother Russ was kicked in the face by a pony, nobody immediately rushed him to the Bastrop hospital, though family friend and black neighbor Aunt Aggie came over to sit for hours with the unconscious boy and pray for him. Russ and his sister often had visited Aunt Aggie to share meals of opossum and sweet potatoes. ${ }^{126}$

\section{The Cash-Side Economy}

Though they might be well fed, happy, and rich in many things, people on the north Bastrop sandylands simply did not have a lot of money, and both bank accounts and coins in pocket declined during the Depression 1930s. As for May Belle Miller's family, it was a consolation that nobody seemed to have much more than they did. Recalling her childhood among eleven siblings, May Belle did not remember feeling especially poor, despite the fact that her family could not afford to exchange gifts at Christmas. Instead, the Millers set up a cedar tree in the house, decorated it with colored paper rings, and prepared a festive Christmas feast of chicken and cakes. Then, to their utter amazement, "A car drove up with two ladies in it, and had a box of toys for us, I guess they heard we was poor people." 127

Evelyn Cottle judged her family at Oak Hill to have been "about average" in cash income, but average on the sandylands meant anything but rich. The family rent-farmed the 400-acre Coulson place until 1939, then managed to buy a smaller property three miles away. Albert Cottle, Evelyn's father, served for eighteen years on the Oak Hill School Board and was otherwise a community stalwart. As a farmer, he typified many others on the sandylands. $\mathrm{He}$ planted corn and occasionally cotton, which he ginned at McDade, but by 1930 he had become a mainly a truck farmer, raising watermelons and cantaloupes, marketing them in his old Model T pickup sometimes as far away as Austin. Albert also raised peanuts, occasionally selling some, and Mrs. Cottle kept chickens for egg money and turkeys for sale at Thanksgiving. ${ }^{128}$

Income from the cash-crop side of the farm shrank during the Depression, however. Once, Albert filled an entire boxcar at McDade with his excellent watermelons and shipped them north on consignment, but received only $\$ 7$ in payment. Cotton prices hovered between a disastrous seven to fifteen cents a pound, and the bottom had fallen out of all agricultural products. It no longer mattered how diversified the farmer was (though at least the watermelon and peanut cultivator could eat his worthless crops). The Cottles gave up their party-line telephone, and eventually these truck farmers had to sell their old pickup truck. Now, the family walked, wagoned, or caught rides with the neighbors.

As in so many other families, Evelyn's mother made virtually all her children's clothing until their high school years. Shoes had to be bought in Bastrop, "Sunday shoes," they were called, and they needed to last. Shoes cost money that families had very little of. Evelyn recalled: "I can remember putting cardboard in the soles of my shoes because I knew my parents really couldn't afford to buy new shoes - I would put cardboard in there to reinforce the soles. I don't know if they ever knew." 129

Despite such austerities, in some ways the Great Depression perhaps weighed less heavily on the families of northern Bastrop County, who were more subsistence farmers than agribusinessmen. Bartering, trading, food 
swapping, work swapping, payment for goods and services with standard commodities (gallon cans of syrup, chickens, and pigs) had never died out on the sandylands, and now these economic transactions outside the money economy made a comeback. Families that might have preferred to birth their child at the Bastrop hospital used a midwife instead, and the midwife might go home with a pig as payment.

From 1920 to the land taking of 1942, every local farm family assembled unique and complex strategies for taking in enough cash money to get by. Many continued to raise some of the old standby cash crop of cotton. Others diversified to watermelons, cantaloupes, sweet potatoes, peanuts, and other truck crops, each year hoping the crop season would be good enough to make commercial quantities of at least one or two of these. Families also sold various incidental products for cash. These included eggs, cream, butter, pecans, fur pelts, cordwood, cedar posts, wine, homebrew, and turkeys, which had become anything but incidental on some farms, where turkeys joined watermelons as the main cash-crop replacements for cotton. When these things still did not bring in enough cash, many family heads and older children also turned to day labor on other people's farms. This "public work" included cotton picking on the nearby Blackland Prairies and part-time or seasonal wage employments.

Every family had their own strategy for making enough money to buy staple foods, purchase the few items of clothing they could not make, arrange for a few school supplies, set something aside for Christmas presents, make bank payments, and pay local taxes. Landowners that failed to accumulate cash for the latter two soon found their farms foreclosed on by the bank or sold for unpaid taxes in "sheriff's sales on the courthouse steps," and there were a good many such unpleasant events, especially during the Depression 1930s. ${ }^{130}$

\section{Cotton}

Cotton money could keep the sheriff away. Some of the people we interviewed, children during the 1920s and 1930s, recalled vaguely that their fathers had produced cotton at some time in the past, ginning it off at McDade or Elgin, but other interviewees had far more vivid memories; no one forgot hard days spent picking cotton. After the cotton bolls opened and the cash crop hung on the plants exposed to wind and weather, many farmers led their wives and children into the field. Irene Fleming's mother and her brother and sisters all picked cotton, with the older children pulling the younger ones, too small to pick, on their cotton sacks. No adult or older child could be spared to stay at home and babysit. Irene recalled picking cotton on days when her toughened feet could barely stand the hot ground. ${ }^{131}$ Sandyland soils became hot in the sun, there was little shade for your bare feet under the skimpy cotton plants, and it hurt your back to stoop to get the cotton. Unlike on the Blackland Prairie and in the Colorado and Brazos river valleys, sandyland cotton grew close to the ground.

Cotton pickers varied greatly in ability. Irene Fleming's oldest brother picked poorly, but her next oldest brother and her mother both picked like champions. As a boy of eight or ten, Jack Scott sometimes went over to pick cotton alongside his uncle, aunt, and cousins for a pay of ten to fifteen cents a hundredweight, though "I couldn't make a hundred pounds a day." However, his aunt Ina Scott would:

pull a cotton sack, and have a baby on the cotton sack and pick 200 or 250 pounds a day. I was right along there close to her and I couldn't get 100 pounds. She'd pick 
two rows at a time and pull that cotton sack with that baby on the back of it. ${ }^{132}$

Sandyland cotton, since it did not grow very large, usually matured early and was harvested early, setting the stage for many local families to go picking on the prairies. The fertile Blackland Prairie of Williamson County lay just to the north, and some families made more money from other people's cotton than they did from their own. Blackland cotton grew chest high, and in a good year the fields turned white as snow. "We'd scrap our little cotton, you know, and go to the prairies," Mary Lou Reese said, comparing sandyland harvesters to the forlorn gleaners of waste remnants on richer ground. "I call [it scrapping] down at Sayers, that poor cotton! Not a cotton community, but everybody planted cotton that had farms." ${ }^{\prime 33}$

One of these local families was the Flowers family, who farmed corn and cotton for fifteen years to pay thirds-and-fourths rent for the land to Frank Dennison, then ran a full subsistence farm as well. They planted ten or so acres of cotton every crop season, though their fields produced poorly. O L Flowers summed up the family's cotton strategy:

The way we used to do, we'd plant ours, ours come in early, so maybe we'd get a bale or maybe two bales of cotton. And Papa would get out there, and we would gather all our stuff, and he and my older brother S T they would go out in the blackland and pick cotton until school got ready to start, and then they'd come in. And me and Mama would stay at home and take care of the livestock. ${ }^{134}$

O L much preferred to stay home and help his mother. However, from time to time he and his mother (an excellent picker) joined the rest of the family on the prairies for a day's picking, and, as $\mathrm{O} \mathrm{L}$ remembered:
I hated it! I swore when I ever got grown I wasn't going to pick no cotton. One thing, I couldn't pick. My back has never been no good, I couldn't stand a lot of stooping over. I would get down on my knees and crawl all day and still couldn't pick no cotton. I tried just as hard as anybody, but I just couldn't move my hands fast enough to get enough to do no good. I could be picking right along on the next row aside another guy, we get to the end and get to the scale and he'd have fifty or sixty pounds more than I did, and we's going along together ${ }^{135}$

The Flowers family ginned their bale or two of home-grown cotton at McDade, as did virtually all area families after the gins at Sayers and Oak Hill closed around World War I. While the family picked their seed cotton, they accumulated it in a pile at the field. Then they borrowed a neighbor's big cotton wagon that would hold the 1,500 pounds of seed cotton necessary to make a 500-pound bale. Sometimes it took all four of the family's mules to pull this heavy wagon through the sandy field to the public road:

We carried it to the gin. We'd go the gin with my daddy, and we'd watch them unload. Pull that wagon under that sucker and suck that cotton off, and go in the gin and watch it come down and go over yonder, and directly seed going over here, and cotton going over here. My daddy, he couldn't figure, give him a paper and pencil, he couldn't figure, but he'd carry a bale of cotton to town and he'd tell you exactly how much money he had coming out if it. ${ }^{136}$

Sale of the cotton went on then and there, "Whenever the bale of cotton come out of that press and set out on that platform out there, then that's when it was sold." Then came settling up for the year with the white landlord, Frank Dennison. If the Flowers family had a good 
cotton year and sold two 500-pound bales at the so-so price of 25 cents a pound, and if they paid for their ginning with all of the cottonseed, they made \$250. They owed Dennison one-fourth of this money, plus payment for the family's several months of credit purchases at Dennison's store near Sayers. ${ }^{137}$ No wonder they still needed to go picking on the prairies.

\section{Evolution to Truck Crops}

Other families had economic strategies based around the sale of both cotton and of truck crops, and some even had renters of their own. Morris Kastner's young widowed mother owned a 495-acre farm a few miles from McDade, but Morris recalled living in a poor, small, boardand-batten house only a little better than those of his family's four Mexican sharecroppers. Mothers and fathers did not bother to inform their children about dollars-and-cents matters in those days, but Morris remembered little spending money, many frugalities, and so much hard work he was glad to reach his bed each night. The renters used the Kastner's work stock, lived in their houses, and produced crops of cotton and corn on approximately forty acres apiece - this for a rent of one-half of the crops, minus their "furnishing," credit underwritten by the landowner at a store. The Kastners marketed these crops for the sharecroppers, as was the custom, then settled up with them. Meanwhile, Morris's mother directed her children in the operation of as large a combined subsistence and truck-crop farm as the child work force allowed - big garden, orchard, turkeys, and crops of watermelons, cantaloupes, peanuts, and sweet potatoes. The family used these crops, but they planted much beyond family need and sold the excess in town. ${ }^{138}$

Others did much the same. The old Southern dream of wealth achieved through cotton faded slowly on the north Bastrop sandylands (especially since the dream still flourished just to the north), but after 1920 most farm families gave up on cotton and diversified to truck crops, crops they could both sell and consume. Cotton put all your cash-crop eggs in one basket, while truck crops spread things around. If you planted watermelons, cantaloupes, sweet potatoes, peanuts, corn, and other things as potential cash crops for the year, surely the season would suit one or two of them, and you would make enough to sell. Watermelons had risen to the top of the list among local cash crops, followed at a distance by a free-range barnyard fowl kept by most housewives, the turkey. Robert Smith, Ruth Smith's father (Figure 3-18), still raised some cotton, but one year he made $\$ 400$ an acre on his watermelons, and her mother's small-toaverage turkey operation cleared around $\$ 125$, as much as a bale of cotton sold for 25 cents a pound. ${ }^{139}$ People began to think, "Who needs

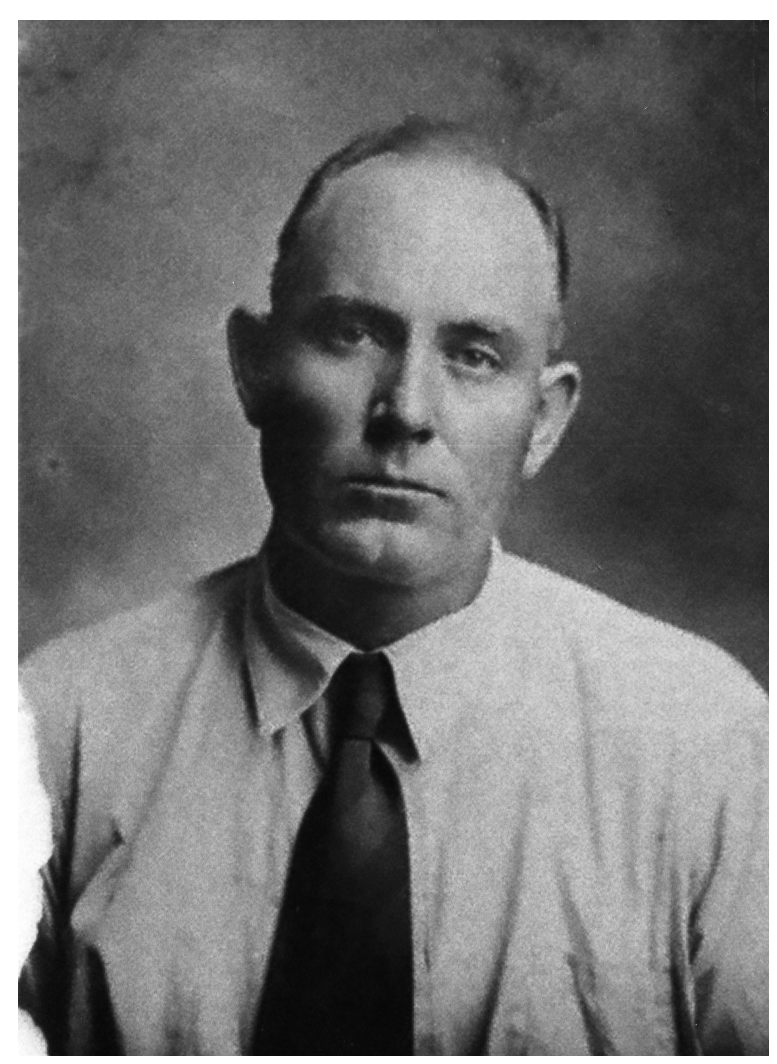

Figure 3-18. Robert W. Smith, date unknown (Ruth E. Smith). 
cotton?" Watermelons were much less labor intensive, and turkeys, like free-range hogs, practically raised themselves on wild foods, though they needed a little more watching after than hogs.

\section{Watermelons}

Willie Blackwell had spent much time in the cotton fields growing up, but after his marriage he raised watermelons and cantaloupes as his family's money crops. As his daughter Leola recalled, he

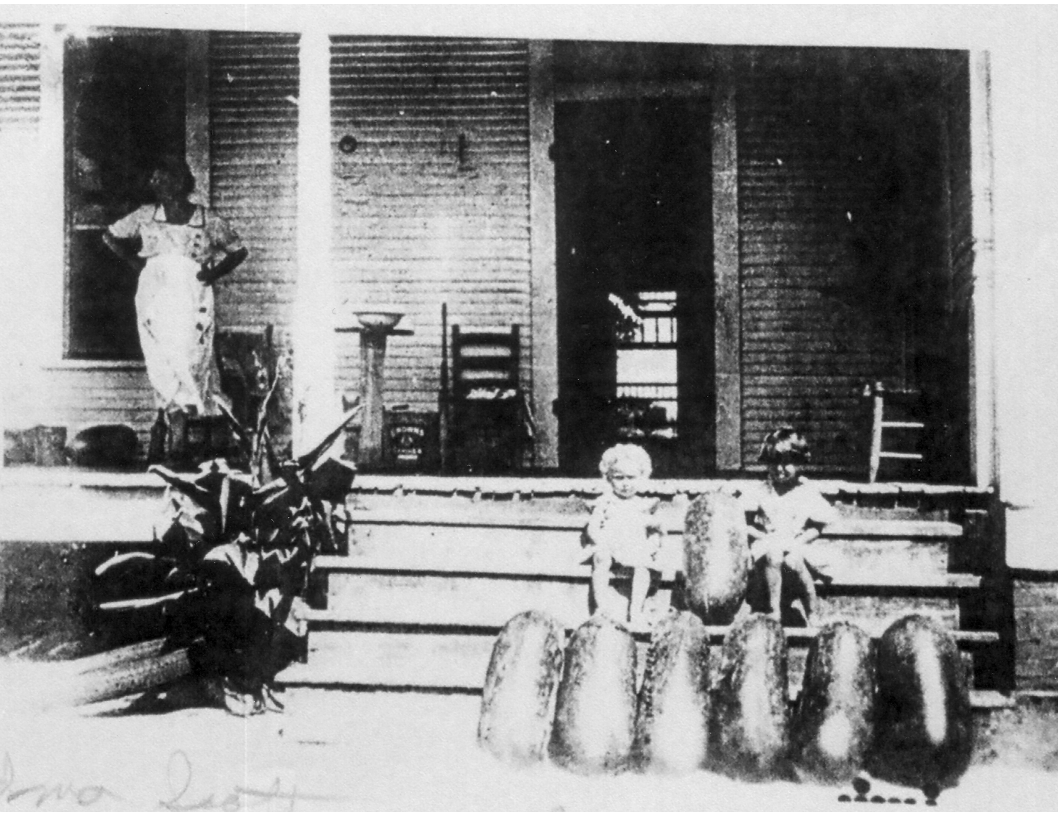

Figure 3-19. Abner Scott's grandmother Minnie Lea Scott and Abner's sisters Mary Lou and Jesse Lee Scott showing off watermelons, ca. 1932 (Abner C. Scott). went about this with scant attention to the advice of

Progressive Farmer or the county agent. "He had a certain way of doing it, and it worked, and that's what he did." 140 Most local farmers put manure on their watermelon fields - something rarely if ever done for cotton and corn, at least in this area. Watermelons grew so vigorously (if it rained!) that they quickly covered the ground around their rows and suppressed weeds, thus requiring little attention. Willie liked to cultivate the middles between the rows once or twice early on, however, and Leola or her brother or sister recalled preceding the plow down the middle of the rows flipping the vines over to the other side of the row with a stick. Willie followed behind with a mule and the shallow-running sweep plow, cutting weeds and aerating the soil. At the end of the middle, child vine-flipper and plowman father turned and did the same thing down the other side of the row of watermelons.

Watermelon harvest required a day of heavy lifting but lacked the tedium of cotton picking.

You quickly "made a show" with watermelon harvesting; the wagon or pick-up bed quickly filled in the field, and if you dropped one accidentally (or on purpose), you had instant refreshment (Figure 3-19). Willie's other daughter Bettye recalled:

We ate them any time, but the very best was when in the very early morning we would finish loading the truck our hands would be dirty and we burst open a melon and use some of the heart and let the juice clean our hands and start eating the rest of the heart. Daddy did not like us to eat watermelons in the field, he felt it brought in coons. ${ }^{141}$

That was a problem with watermelons raccoons, hogs, and human thieves all loved to eat them (Figure 3-20). Sometimes, as in the case of the Reese family, the thieves were close at hand. Mary Lou Reese remembered:

Go to the watermelon patch, Papa wasn't ready for us to eat them yet, we'd pull watermelon, so many green half-ripe 


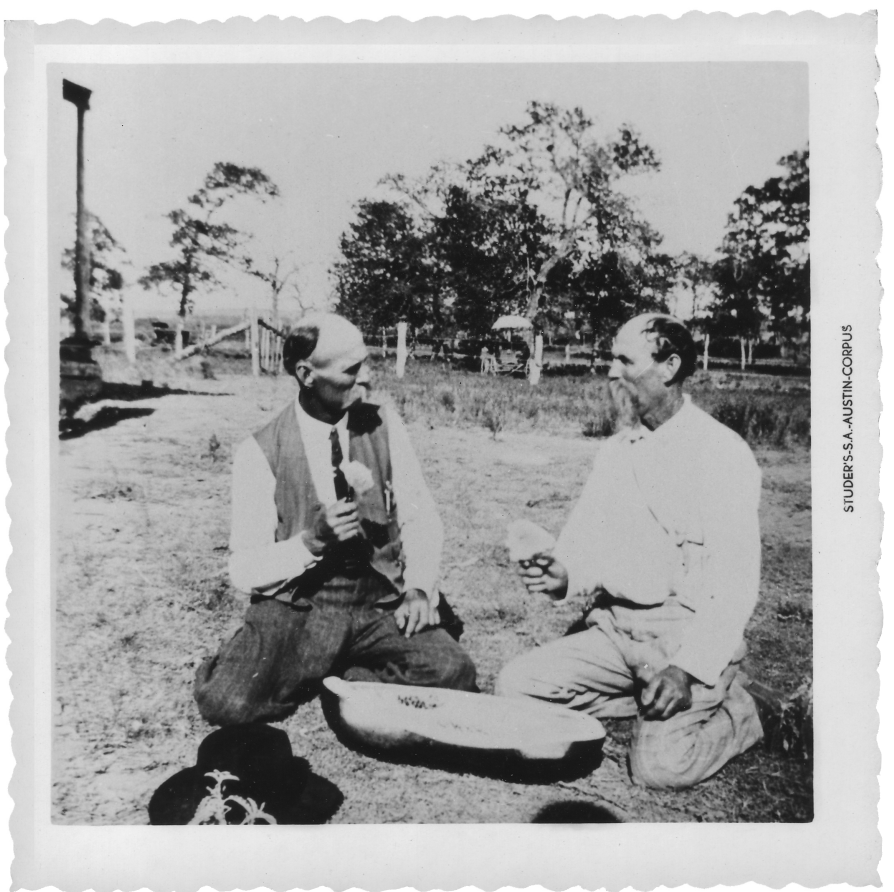

Figure 3-20. T. W. and brother Bill Owen eating watermelon at T. W.'s home across the road from Oak Hill Cemetery ca. 1900 (Fay Owen Pannell).

ones, went in the corn patch and buried them - thought we'd buried them. Papa went along a week after that and saw where we'd eaten watermelons in the corn patch. He didn't say nothing but just wanted an honest reply. Had plenty of 'em anyway.

Later, the young Reeses pilfered watermelons from the watermelon field near the road, where their father would assume that passing strangers had done the deed, but that too "wasn't no penitentiary offence."'142

This unauthorized "grazing" on family farm products continued; ordered to kill and cook a chicken while Mr. and Mrs. Reese went to town, the Reese children instead killed and cooked two of them, entirely consuming the bird before their parents returned. A sister had advised her younger brothers, "Every chicken got two things, be sure its not three" when the parents get back. An unnatural third drumstick would give them away. ${ }^{143}$
Some watermelon farmers took things more seriously. Ruth Smith's father had problems with watermelon thieves during the season that he made $\$ 400$ an acre from his crop, and he confided to a black neighbor that he planned to watch his melons one night with a shotgun. "You better not, you might shoot your best friend," the man warned. The thief and friend was a white neighbor, and the black man knew it. ${ }^{144}$

Watermelons lacked the mystique of cotton, but sandyland farmers like Willie Blackwell and Robert Smith did quite well with them over the years. Sometimes you hauled them into McDade as part of a big railroad shipment from the area; sometimes the trucks came to load up at your place. Watermelons and other such crops also offered the possibility of cutting out the middle men to sell products yourself, setting up beside the highway or going door to door in Bastrop or Elgin. Willie often did this with his Kletex, Charleston Grey, Black Diamond, or Tom Fine watermelons. He peddled them to regular customers in Bastrop, or he parked on Main Street and sold to passing townsmen. Sometime he did so well he came home at noon to get another truck load. Bettye recalled that her father was a good salesman, but perhaps a little shaky on the dollars-and-cents side of business deals. ${ }^{145}$

\section{Turkeys}

The Reeses, Smiths, Blackwells, and virtually every family we interviewed also raised turkeys, which had become an important money crop across this lightly-populated, sandy landscape, criss-crossed with grasshopper-rich pastures and post oak groves carpeted with 
fallen acorns. Mary Lou Reese correctly observed:

They got to have some range. Everybody don't live in a vicinity that's just right for turkeys. They all right living way out in the country, 'cause sometimes they go off and stay all night. But seldom. Lot of people used to raise turkeys down home there...They'd come in if you feed them - got to feed 'em to show them where home is...Mama'd sell hundreds of dollars [worth] when she grew turkeys. ${ }^{146}$

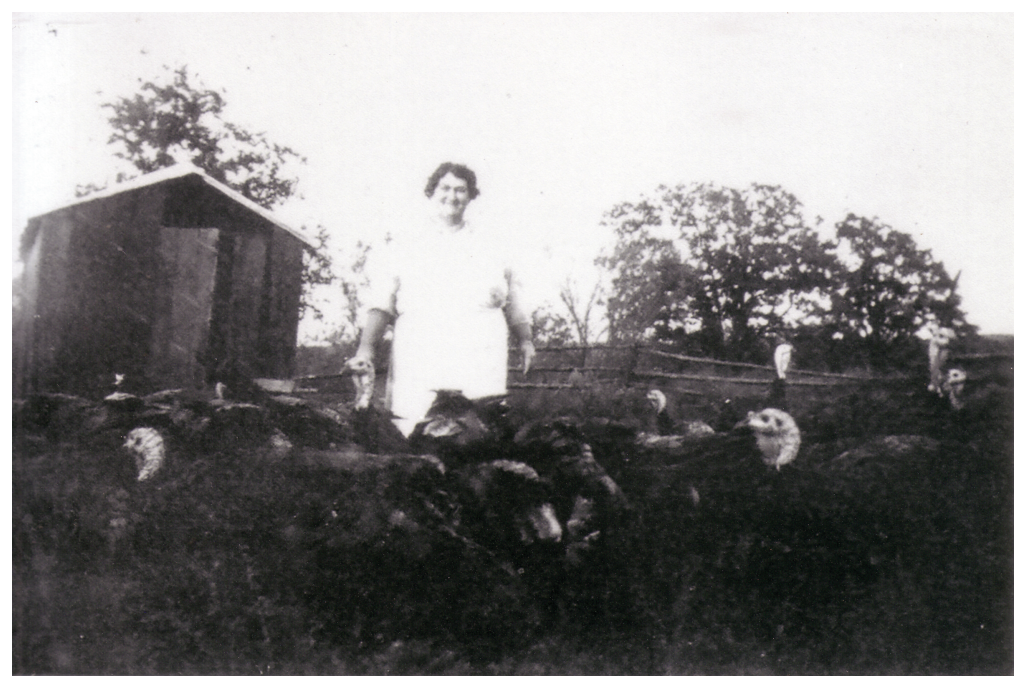

Figure 3-21. Grace DeGlandon Smith (Louise Smith's mother) and her turkeys, date unknown (Louise Smith Goerlitz).
Few interviewees could recall just how much their mothers made from turkeys, but Mary Lou's "hundreds of dollars" seems realistic. Interviewed in 1994, Herman Shoenemann of the Sand Town community in nearby Lee County, lived in another of the post oak free-range areas. Shoenemann raised so many semi-feral turkeys in the woods around his cotton farm one year that he cleared $\$ 1,800$ from their sale just before Thanksgiving - several times what he received for that year's sandyland cotton crop. ${ }^{147}$

Everybody raised their turkeys in much the same way, though there might be important differences in scale of operations. People basically treated turkeys as Southern stockmen did semi-feral swine in free-range districts, allowing them to roam far afield and scavenge for most of their own food. People did, however, need to keep closer watch over the turkeys than they did the hogs, especially to see that they came safely home to roost each evening after a bedtime snack of corn. Even in areas of strict stock law enforcement for hogs, turkeys still wandered freely; stock laws did not apply to them. Neighbors (who usually had far-ranging turkey flocks of their own) had to agree to your turkeys on their land, since turkeys could be "devilish like a hog and get into anything," as O L Flowers said. They might be especially destructive in a ripe patch of sorghum, "milo maize," intended for chicken feed. ${ }^{148}$

Farmwives and their older children usually managed families' turkey flocks, despite the fact that the profits from turkeys might exceed those from their husbands' cotton or watermelons (Figure 3-21). In a small operation, the family might over-winter a cock turkey, or gobbler, and a half dozen hen turkeys. Peculiarities began to emerge as spring laying time arrived - turkeys were wilder fowl than chickens. Turkey hens needed to be allowed to establish their own nests at remote locations in the woods and along the fence rows, then you had to stalk the hens to find their nests and bring the eggs to the henhouse for hatching under a captive turkey hen or broody chicken.

You had to find the nests and the eggs, or the eggs would hatch in the woods, and-unless you were lucky — varmints would get the turkey poults. This was not easy; cautious turkey hens 
had excellent eyesight and hearing and did not wish their nests to be found. Mothers set sharpeyed, stealthy, farm children on their trails, creating vivid memories of days spent turkeystalking. "Mama made me watch those turkeys hens a half a day to try to figure out where she's laying that day," O L Flowers remembered. "Find out you're watching them, and they'd just try to fool you. They'd go this way, and they'd go this way and go this way, and you'd finally find it." 149 Or maybe you would not. Dean Fort often visited relatives at Oak Hill, and he noted:

It was the kids' job when the turkeys started laying to watch the old hen and to watch the nest so they'd get the eggs. And I know my grandmother, she always raised a lot of turkeys, and I had an uncle...he was about three or four years older than me, and that was our job. And we spent all day long trailing one old hen, trying to find her nest, and if she spied you watching her, she would not go to that nest, so you'd spend the whole day and then don't find no eggs... But I spent a many a day following those turkey hens. Find a nest, and Grandma always give us a big spoon, and she said, "Don't put your hand in that nest, because they'll quit laying. Use this spoon. Reach in and get the egg out with the spoon and not touch the nest." And the turkey would go back to the same place, but once you found her nest, you could keep getting the eggs out of it. ${ }^{150}$

Once hatched, the turkey poults were returned to the care of the turkey hens, who immediately began to lead them abroad, first to the barnyard, then the nearby fields and pastures, then to distant woods. By midsummer, the Blackwell family's turkeys roamed three miles away, crossing several neighbors' properties. They ate voraciously: grasshoppers in the fields, berries and other wild fruits in the woods, acorns and pecans as soon as they began to fall. They even ran down lizards and small snakes and gobbled them up, just like roadrunners. Like most people's turkeys, the Blackwells' birds had been marked - in this case, by cutting off a certain toe on a certain foot when they were just hatched. They mixed at times with the neighbor's birds, but the neighbor-after consultation-had cut off different toes, and in any case Blackwell turkey hens almost always led their offspring back home at night for a feeding of corn. But only a little corn - not enough to discourage the quest for grasshoppers and lizards the next day.

Such domestic turkeys were woods-wise and half-feral, but they lacked the instincts and intelligence of truly wild birds; they needed a good bit of watching after by family turkey herders. Bettye Blackwell recalled:

They went almost to Highway 95, we lived almost three miles through the woods to there. There would always be close to 100 turkeys. We had an old turkey hen called "Bell" because she wore a bell around her neck, and every day she would head. As they got bigger there was an old big old oak tree by our watermelon patch, and this old hen would start those turkeys up this tree. Daddy and [my brother] George would see them up this tree at night and be there at daylight to see them down and stay with them. Sometimes I would meet Leola and George halfway home with water and something to eat. That was our cash crop and probably helped buy our shoes. They were caught and sold in the fall. ${ }^{151}$

Leola Blackwell well remembered these long childhood days of turkey herding. She spent most of the time just sitting and watching them forage. Willie usually walked over from the field once or twice a day to check on his oldest daughter. Leola explained: 


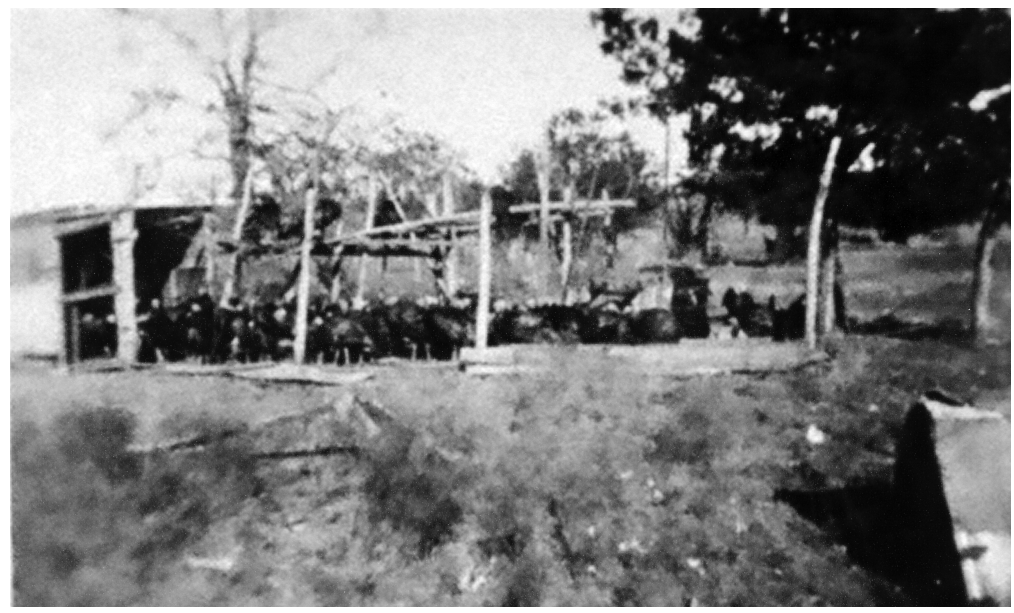

Figure 3-22. Grace DeGlandon Smith's turkeys in a pen (Louise Smith Goerlitz).

That was my job after they [the young turkeys] got up big enough to follow the old hen to the field to graze for insects, that was my job to follow 'em, to see where they went, and then drive 'em home at night. You just kind of keep the old hen going in a certain place, just kind of walk around them and turn them around, and get 'em going back the other direction. ${ }^{152}$

Safely herded through the summer, turkeys gorged on acorns during October and early November, fattening themselves for Thanksgiving sale. Some families put their turkeys behind fence to "finish them off" with big feeds of corn, but most did not bother (Figure 3-22). Mercantile stores in town bought turkeys before the holidays, often sending trucks from farm to farm in the countryside to get them.

\section{Harvesting from the Free Range}

Families sold other things from time to time-products of their land and products gathered free of charge from other people's land by virtue of old customary use rights or free-range rights, which still persisted in heavily-wooded, thinly-settled areas like the
Bastrop sandylands. Fur buyers set up in Bastrop in the winter and bought thousands of pelts from men and boys who mixed business and pleasure in hunting and trapping for opossums, skunks, ringtails, and the occasional grey fox or raccoon. Ringtail pelts brought the most, opossum pelts the least. Steel traps were troublesome and cost too much for farm boys like Abner Scott, who preferred to go out at night with his light and his dogs Joe and Blue to tree furbearers and shoot them out with a .22 rifle. Abner explained: "You could see the eyes of 'em with that light, they'd look at you, and I could shoot that eye out with my .22. That way, you didn't tear the hide any, if you shot 'em in the head. ${ }^{153}$ The young Abner rarely paid much attention to whose property he was on when he shot a ringtail or skunk; it was not supposed to matter. Hunting was one of the old free-range rights; you hunted on neighbors' land and neighbors hunted on yours, and for most landowners (but not all) it truly did not matter (though times were changing). Certain areas remained indisputable free range long after other places began to discourage trespassers - such as the unpopulated sand hills of the Alum Creek drainage south of Oak Hill. ${ }^{154}$

The old open-range way was free-handed and neighborly, as Abner explained, "neighbors were neighbors, and what you have is theirs and what they have is yours." ${ }^{155}$ Sometimes it worked just like that. Doll Fort let cedar cutters cut cedar posts from his land for free and to get a little more open space. ${ }^{156}$ Doll and others often also allowed the free cutting of cordwood intended for personal use. 
Cedar posts and cordwood also sold for cash, as did eggs, butter, cream, and pecans. Whatever special things a family had enough of to sell, they sold, as the Grover Scott family did the pecans from their pecan groves along Big Sandy Creek. ${ }^{157}$ Cordwood, usually post oak or blackjack oak, still found ready markets with townsmen that used wood stoves, but the trade was in decline. Kerosene and natural gas stoves now replaced wood-burning ones, and diesel gins replaced steam gins on the Blackland Prairie. Each of the latter once had burned hundreds of cords of wood a year.

\section{Public Work}

As with other heads of households, Grover Scott's pecan grove and watermelon and sweet potato fields did not bring in adequate cash, so rather early Scott had turned to part-time or seasonal public work, wage labor for others outside of the farming life. Perhaps Grover

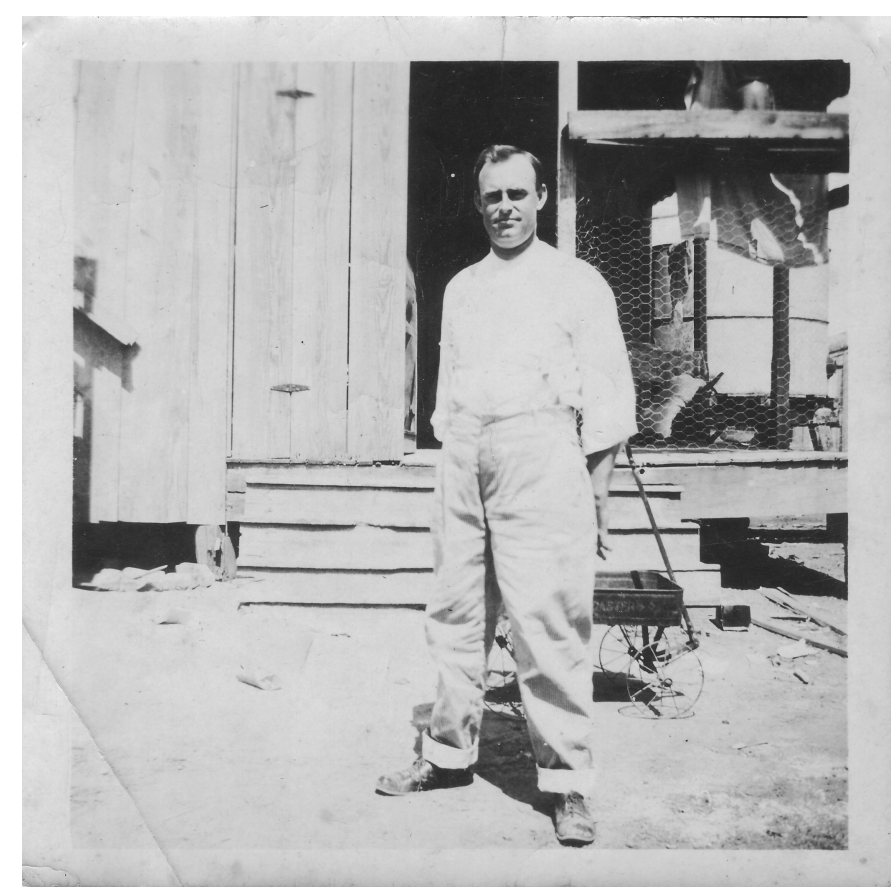

Figure 3-23. Joe Owen, manager of the Sayers Store, stands at back of the store ca. 1915 (Fay Owen Pannell). His family's living quarters were in the back. rather liked this; it enabled him to buy an early Model A Ford to commute to distant jobs. He worked as a carpenter building wooden derricks in the Lytton Springs oil field, and later worked at the Butler Brick Plant east of Elgin. Even Willie Blackwell, who disliked laboring for other men and taking their orders, took government work on Works Progress Administration road projects for a time to bring in hard cash during the $1930 \mathrm{~s}^{158}$

Other government projects offered public work for some Bastrop county men during the Depression, notably the Civilian Conservation Corps (CCC). In 1933 and 1934, Company 1805 and Company 1811 of the CCC helped re-forest the Lost Pines and build Bastrop and Buescher state parks. ${ }^{159}$ Evelyn Cottle, Fay Owen, May Belle Miller, and Irene Fleming all had brothers in the $\mathrm{CCC}$, most of them employed locally. ${ }^{160}$ Three of Fay's four brothers joined up. Recruits got $\$ 1$ a day and sent $\$ 20$ a month home to their families, and the money meant a lot. ${ }^{161}$ May Belle remembered, "Thirty dollars a month, and that was money! It really helped out, gave us a little money to live on. Other than that, wasn't no money coming in." 162

Many local sandyland farms had been marginal to begin with, and over time soils had depleted with repeated use and properties had subdivided among big families. By the late 1920s, a good many farm families on the sandylands periodically sent one of their number, the father or the oldest son, to work in the nearby oil field, the brick plant, or McDade's famous pottery. Some people disliked this necessary cash labor, and some did not. Fay Owen's father Joe (Figure 3-23) clearly numbered among the latter group. Joe had grown up in 


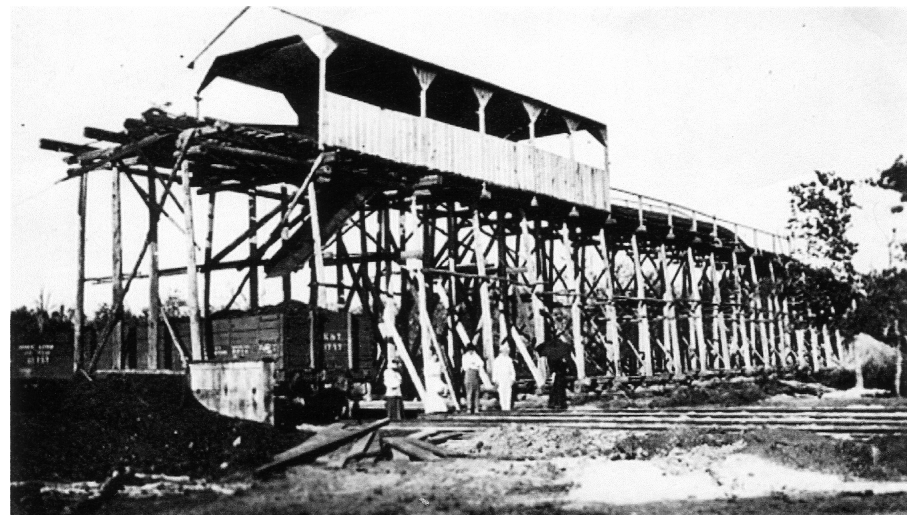

Figure 3-24. Graded tipple leading from Frank Dennison's slope mine, operated from 1914 to 1924 (Fay Owen Pannell). Lignite from the mine carts dumped into MK\&T tailcars for transport to the main line 2.5 miles southwest. lignite mine just east of Sayers (Figure 3-24). Elgitha and their five children stayed home to run the farm while Joe came home on weekends. Daily shifts of fifteen to twenty Mexican miners laboriously picked coal from the shafts of this shallow, small-scale mine, shipping the lignite out on the railroad (Figure 3-25). The amiable Joe got on well with the Mexican workers and even learned some Spanish, but he rarely left the mine to visit his family, who lived only a few miles away. As Fay explained, "Anytime he left there the family cotton field and picking on the prairies, and Joe had concluded, along with $\mathrm{O}$ L Flowers, that he wanted nothing else to do with cotton. Even before his marriage he sought public work, for a time leasing and managing the small Sayers mercantile store owned by the Bell family. Later, he managed the store with his new wife, Elgitha Smith Owen. Joe liked machinery, especially automobiles, and he liked socializing with people; hard lonely days in the field did not suit him. His daughter said of him, "He was one of those people that if he could round up cattle with a pickup, he did. He wasn't too good at farming, he didn't like the farming part. He was a big talker, he loved to visit." The Bell family soon put Joe out of their store for his extravagance of buying a Model $\mathrm{T}$ (presumably demonstrating too great a profit at the Bells' expense). He built a house at Oak Hill and farmed, then from 1926 to 1928 , he took more public work as superintendent of the Sayers Coal Mine, Frank Dennison's small

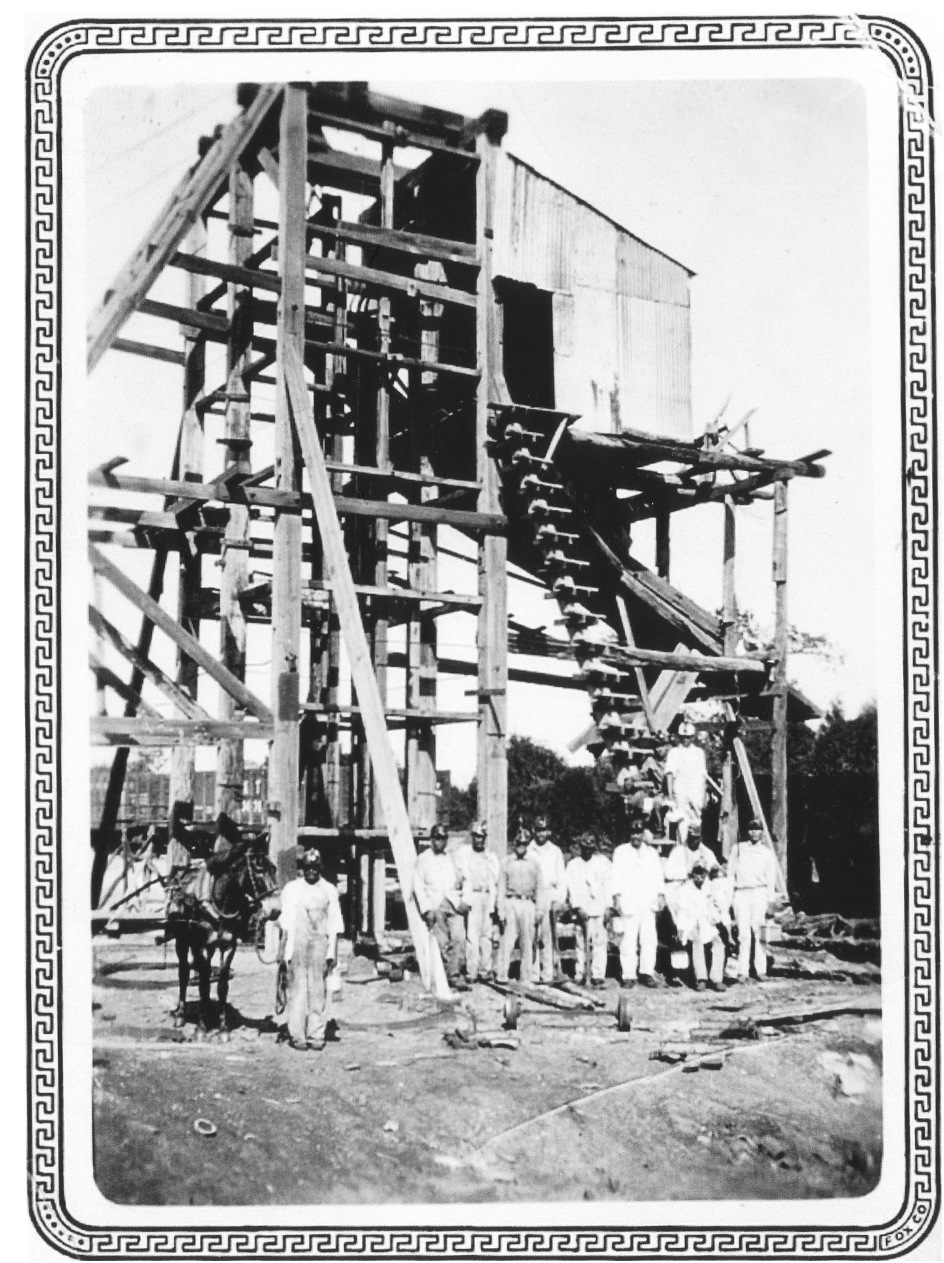

Figure 3-25. Mexican laborers in front of the Sayers Coal Mine, date unknown (Fay Owen Pannell). This upright tipple constructed over a vertical shaft was used from 1924-1928 to hoist lignite from below. 


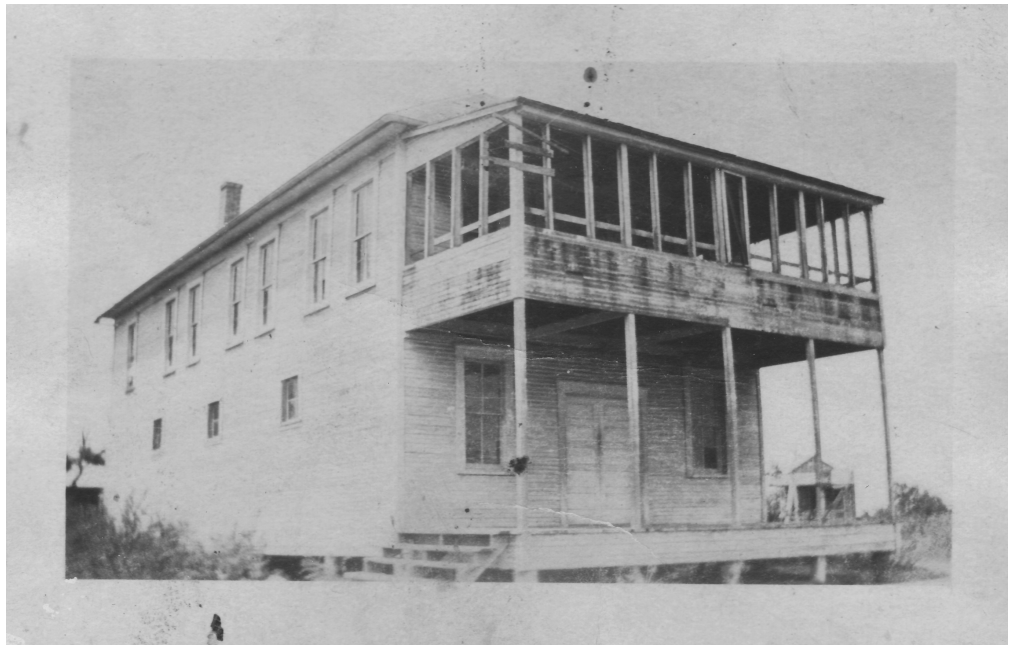

Figure 3-26. Sayers Coal Mine Commissary, date unknown (Fay Owen Pannell).

for any length of time, some of the Mexicans would break in the store, which is downstairs, and steal stuff, so he couldn't leave" (Figure 3-26). Joe lost his job managing the mine after the operation suffered a devastating fire in 1928 and Frank Dennison shut it down for good. After that, the Owen family operated a small dairy on their 88 -acre property at Oak Hill, with Joe much enjoying his daily delivery trips to customers in Bastrop. ${ }^{163}$

\section{Owen Chronicles Economic Disaster-Community and the 1925 Drought}

By 1925 , most farm families on the sandylands practiced a mixed strategy of agricultural subsistence and cash cropping with a little public work on the side, but events of that year showed just how quickly economic disaster could fall on all their endeavors. Every year was a new season, a new roll of the dice, and 1925 brought a terrible drought to this hardscrabble farming world.
But 1925 also witnessed the courage and endurance of the farm families on the sandyland, and their cohesiveness of community. The eastern hinterland of the small railroad town of Sayers took in part of the 87 square miles, and a few dispersed rural communities had a shadowy existence - Wayside, Dogwood, Piney Creek, Spring Branch, and Duck Pond, but the core community was Oak Hill. There was nothing shadowy about Oak Hill, which had a school, church, cemetery (and active cemetery association), and in earlier times a gin and store. Oak Hill had a weekly chronicler in the Bastrop Advertiser, Mrs. Edgar "Polly" Owen (Figure 3-27), who

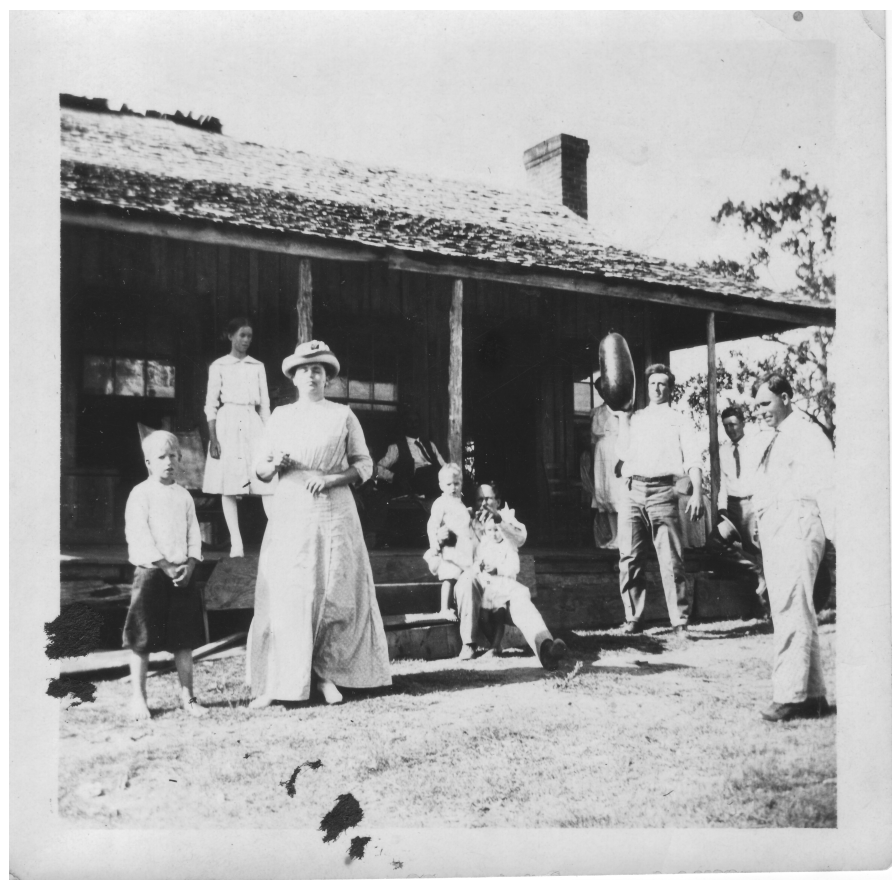

Figure 3-27. Polly Owen of Oak Hill (left foreground) and other members of the Owen family in front of T. W. Owen's house across the road from Oak Hill Cemetery ca. 1914 (Fay Owen Pannell). T. W. Owen with his grandsons in center, seated, and Polly's husband Edgar is at the far right. 
for a quarter of a century reported the news of her home community to the courthouse-town newspaper.

Polly called the yearly round of events at Oak Hill, reporting the agricultural cycle of planting, cultivating, harvesting, and beginning again, all affected by the random events of season. She chronicled the community-wide social affairs of school, church, cemetery association, and the active programs of county farm agents and county home demonstration agents. Like the medieval chroniclers, she also told of individual births, deaths, and disasters, and had much to write about in 1925 .

As she did in other years, Polly emphasized Oak Hill community spirit and community progress, with occasional side glances at the horrendous drought that grew upon the countryside. Probably she thought that her readers did not need to be repeatedly informed about the lack of rain.

The year began with "dry northers that will certainly dry the land,"164 and by Polly's column of early February, few families had planted gardens or early corn, since they judged the soil too dry for seeds to germinate. Pasture fires had been a constant problem, and John Scott (Abner Scott's grandfather) had just suffered a big one. Oak Hill School often served as the site of community meetings, and people had just met there to organize a Sunday school for the church. ${ }^{165}$ In late February, the two agricultural extension service agents also met at the school to hold boy's, girl's, and women's clubs meetings. Oak Hill girls received a useful lesson in sewing button holes, and later the county agent spoke about pest control. ${ }^{166}$

During April, the events that marked the ceremonies and celebrations of "school closing" began, first with a "declamation contest" held at the church on April 2, doubtless with contestants taking the pulpit to speak. Ladies sold candy to the considerable audience to benefit the school; rural people often were starved for entertainment, and their schools often put on the best shows in town. ${ }^{167}$ On April 23, Oak Hill School's formal school closing program and festivities took place before a large audience. A Baptist minister out from town gave the invocation, students made speeches and staged a play, and adult school supporters served food and refreshments. Communities often added baseball games, picnics, and barbecues to such affairs, as perhaps did Oak Hill. Irene Fleming received an award at this school closing for passing through the entire eight-month school term without missing a single spelling word. ${ }^{168}$

All was not well, however - in fact, things grew ever more distressing. By the end of April a "little sprinkle" had fallen on Oak Hill, but not enough to plant corn and gardens, and the season was now very late. Corn and gardens planted late all too often died in the hot Texas sun. Since local farmers could not plant until it rained, they traveled far afield seeking temporary jobs in the oil fields and elsewhere. "Most everyone is trying to work or to get work till it rains," Polly wrote, showing her deep concern. ${ }^{169}$

Then, the gamble of season took a dramatic turn. A moderate rain in the first week of May, followed by a small rain in the second week, triggered a full spring planting - not just cotton, corn, and watermelons, but all the garden crops and traditional spring crops that should have gone in the ground by early April. Farmers had to be gamblers, and now they took a chance. But was this a mistake? By late May no additional rain had fallen, and the wild dewberries and plums - portents of the crop season to come - had failed. ${ }^{170}$ 
No rain fell on the north Bastrop sandylands in June - a horrible deficit, and the dry sandy soils blew in the hot winds of premature summer, drifting through the screenless doors and windows and cracks in board-and-batten walls to form films of dust on every horizontal surface inside the houses. Meanwhile, Polly Owen ignored the drought to chronicle Oak Hill progress. On June 4, an official from Texas A\&M Extension Department at College Station "scored the improved kitchens" of Mrs. Joe Owen of Oak Hill and Mrs. John Scott of Wayside. These kitchens could now serve as models for others. ${ }^{171}$ The Oak Hill Cemetery Association met to plan its annual picnic of June 26. ${ }^{172}$ Come one come all, Owens encouraged readers of the Bastrop newspaper. On June 25, the new county home demonstration agent, a young unmarried lady just on the job, lectured the Oak Hill Women's Club on "appropriate dress," probably at Oak Hill School. ${ }^{173}$ A slight undertone of reserve registered in Polly's account of this affair. Did Oak Hill women already believe they knew how to dress appropriately?

July also began with upbeat news in Polly's column. The 18th Annual Oak Hill Cemetery Association Picnic had been a great success. Graves had been cleaned and each one freshly mounded with earth, then graveyard cleaners had celebrated the day by consuming a prodigious picnic dinner, including pit barbecue, at the adjacent picnic ground. Polly reported that the county agents had hosted the annual boy's and girl's encampment at the Bastrop County Fair Grounds. This event included talks, demonstrations, lectures, games and songs, and even some adult males - usually reluctant consumers of the county agricultural agent's admonitions - had shown up..$^{174}$

Probably they had nothing better to do. The drought continued. In late July, Polly reported that all crops but the cotton now needed rain badly and were in trouble. The "hot, dry wind" of last week damaged even the drought-resistant cotton, and many squares (precursors of bolls) were falling off. Melons and corn had died in the field, and cattle were beginning to die in the pasture. With no grass and no corn tops, cattle had nothing to eat. "Laid by time" had arrived, the time for ceasing cultivation of finished crops, maturing toward harvest - a dream of yesteryear in this season of crop disaster - but people went on fishing trips and family visits anyway. Why not camp out for several days on the "Silver Colorado" to fish, swim, and forget your troubles? Back at Oak Hill, the county home demonstration agent gave biscuit making demonstrations at the homes of Mrs. Minnie Shelton and Mrs. John Scott. ${ }^{175}$

By late August, as readers already knew and Polly did not bother to mention, doom had fallen on almost all area crops. Farmers could read in the paper about the wonderful cotton season of 1925 across the South, but they knew they had not participated. Even in the Central Texas disaster zone, there had been anomalies; a "two bit rain" fell from a freak cloud over Ruth Smith's father's watermelons, and he made a crop worth $\$ 400$ an acre. Some people had snapped under the strain: a Cedar Creek man hanged himself in his pasture, an Oak Hill man, overcome by "bad air" while cleaning out a dry well, fell and broke his neck. ${ }^{176}$

Still it did not rain. On September 3, the new "teacheridge" (residence for teachers) opened at Oak Hill School, "a neat modern building that anyone would be proud of." The three Oak Hill school trustees just attended the county school superintendent's general meeting for all rural school trustees. ${ }^{177}$ On September 10, the county home demonstration agent and the girl's club put on a cooking demonstration at Polly Owen's 
home, preparing scalloped tomatoes, creamed and baked potatoes, fried chicken with creamed gravy, biscuits, and cabbage and apple salad. ${ }^{178}$

This season's crops dead in the ground, in September Polly described local farmers' patient preparations for the next crop season - "bedding up" for next year, planting turnip greens and oats for chicken feed, and other things. Life and death went on as always: "The death angel visited the house of Mr. and Mrs. Tom Jones and took their infant daughter." Now, after the crop season had ended, Polly wrote explicitly of "empty barns, empty fruit jars." Not only had the money crops failed, but all subsistence crops had failed as well; women had no produce to can. Barns were empty because a lack of forage for the winter (and a lack of money to buy forage) had forced sale of milk cows and some work stock. With no corn to feed them, flocks of domestic fowl nearly disappeared. ${ }^{179}$

On October 1, Polly reported that Oak Hill School had held opening ceremonies on September 28, with 41 students reporting and Mr. Billingsley in charge as principal teacher. At the end of ceremonies, all present joined in singing "Old Black Joe." Then the two teachers "classified" the students, assigned them to classes. ${ }^{180}$

On October 22, the McDade correspondent to the Bastrop paper noted that the drought had broken the week before, not to save the crops - it was far too late for that, except for a little "top-crop" cotton - but as yet another disaster to be endured. Over 17.5 inches fell in two days, destroying bridges, washing out roads, knocking down fences, gullying fields, and drowning work stock. Polly chose not to mention this watery event; perhaps she thought her readers already knew about it. Perhaps this resolute optimist and community booster simply could not bear to comment on the second great agricultural cataclysm of 1925 .

Instead, beginning with her column of October 22, Polly's focus shifted to zealous preparations for a box supper to make money for Oak Hill School. The school and school grounds had received a thorough going-over; even the desks had been re-varnished. ${ }^{181}$ In mid-November, Polly reported the successful box supper in great detail. After opening remarks by Principal T. G. Billingsly, all had sung "America the Beautiful." Students gave readings, Bastrop High School faculty women gave a talk on "physical training in the school," and students put on a one-act play, "The Kitchen Orchestra." Then the county school superintendent, somewhat nervous at his role, auctioned off the box lunches. Students sold cakes, pies, and candy, while ladies sold cocoa, coffee, chili, and chicken salad sandwiches. "All have resolved to make Oak Hill the best rural school in Bastrop County," Polly reported. ${ }^{182}$

In Polly's column of December 10, 1925, comments on the yearly round resumed, and next year was another season, another play of fate. She told of hog killing on every farm and of turkeys sold at market - what few there were to sell. ${ }^{183}$ As fall turned into winter, sandyland farmers went about their business, bedding up eroded fields in preparation for the next crop year. Farmers were gamblers, and every new season was another game of chance. Some despaired, but most were stoic, and some even viewed the events of 1925 with a grim humor, noting that at least they were beginning 1926 after a good rain. ${ }^{184}$

\section{School and Social Life}

Many other people shared Polly Owen's opinion that Oak Hill School (Figures 3-28, 3-29, 
3-30, and 3-31) would become (or was already) "the best rural school in Bastrop County." 185 This attitude had not changed by 1934, another bad crop year and this time in the depths of the Great Depression. Community pride and solidarity focused on the school. Residents of Oak Hill Common School District somehow managed to scrape up the money for a down payment on a piano for the school in 1934, proudly accepted its delivery, then staged a big

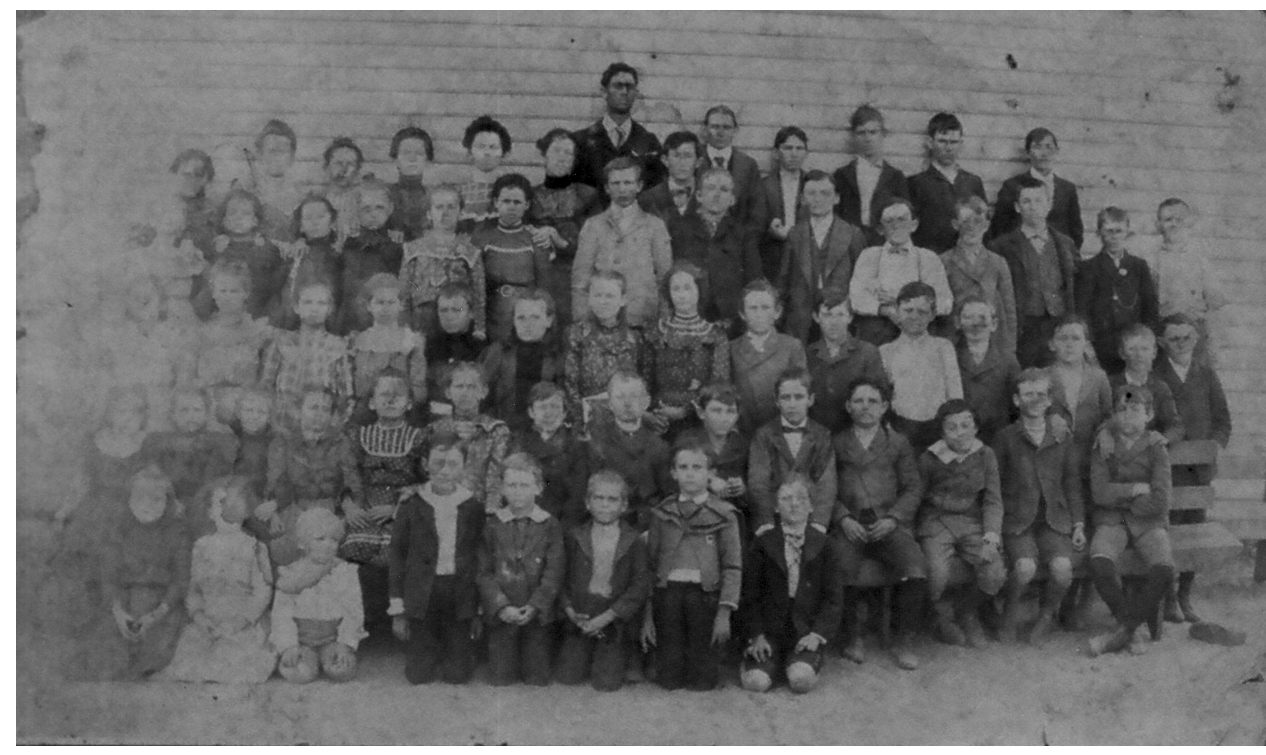

Figure 3-28. Oak Hill School, 1902 (Ruth E. Smith).

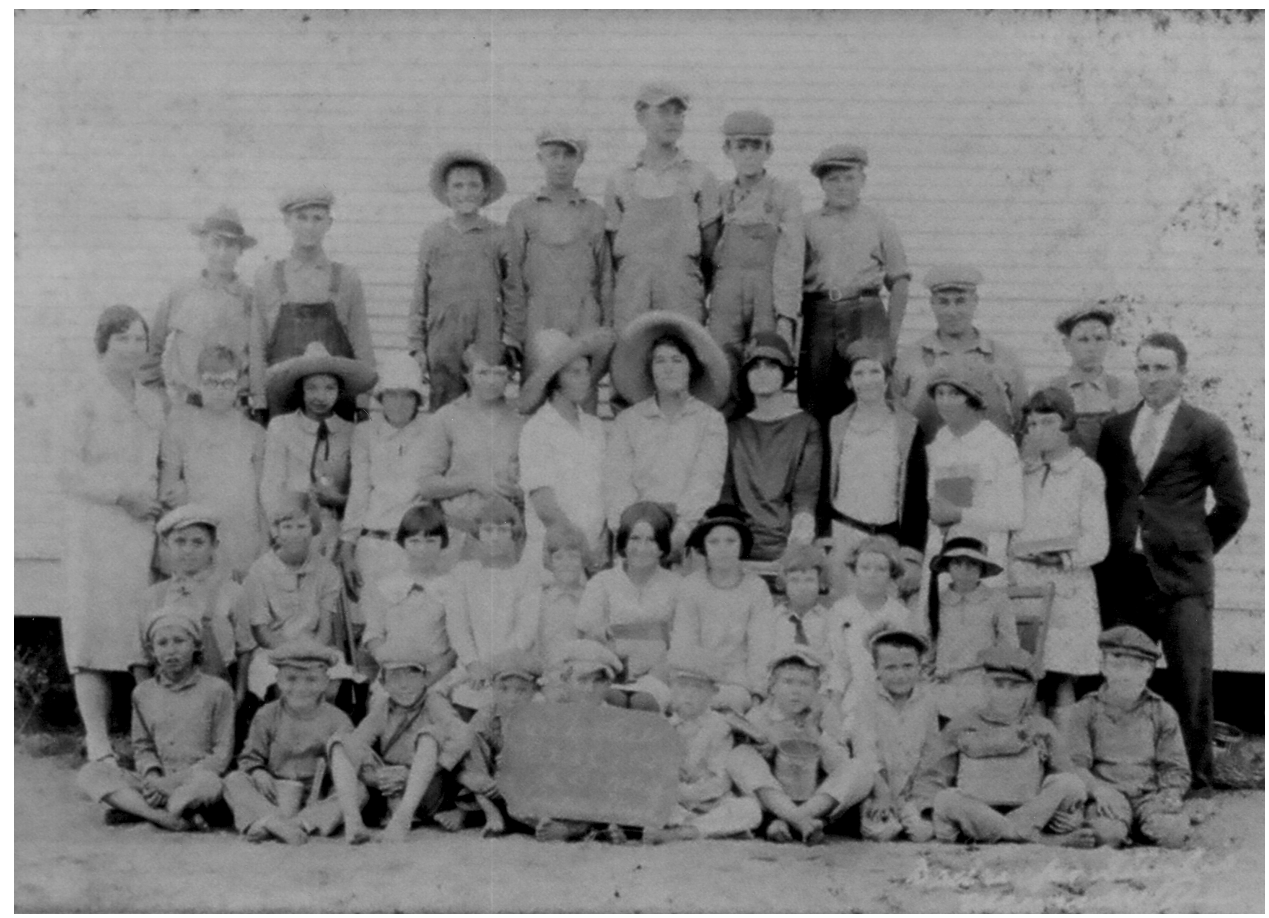

Figure 3-29. Oak Hill School children in big hats, 1927 (Ruth E. Smith). 


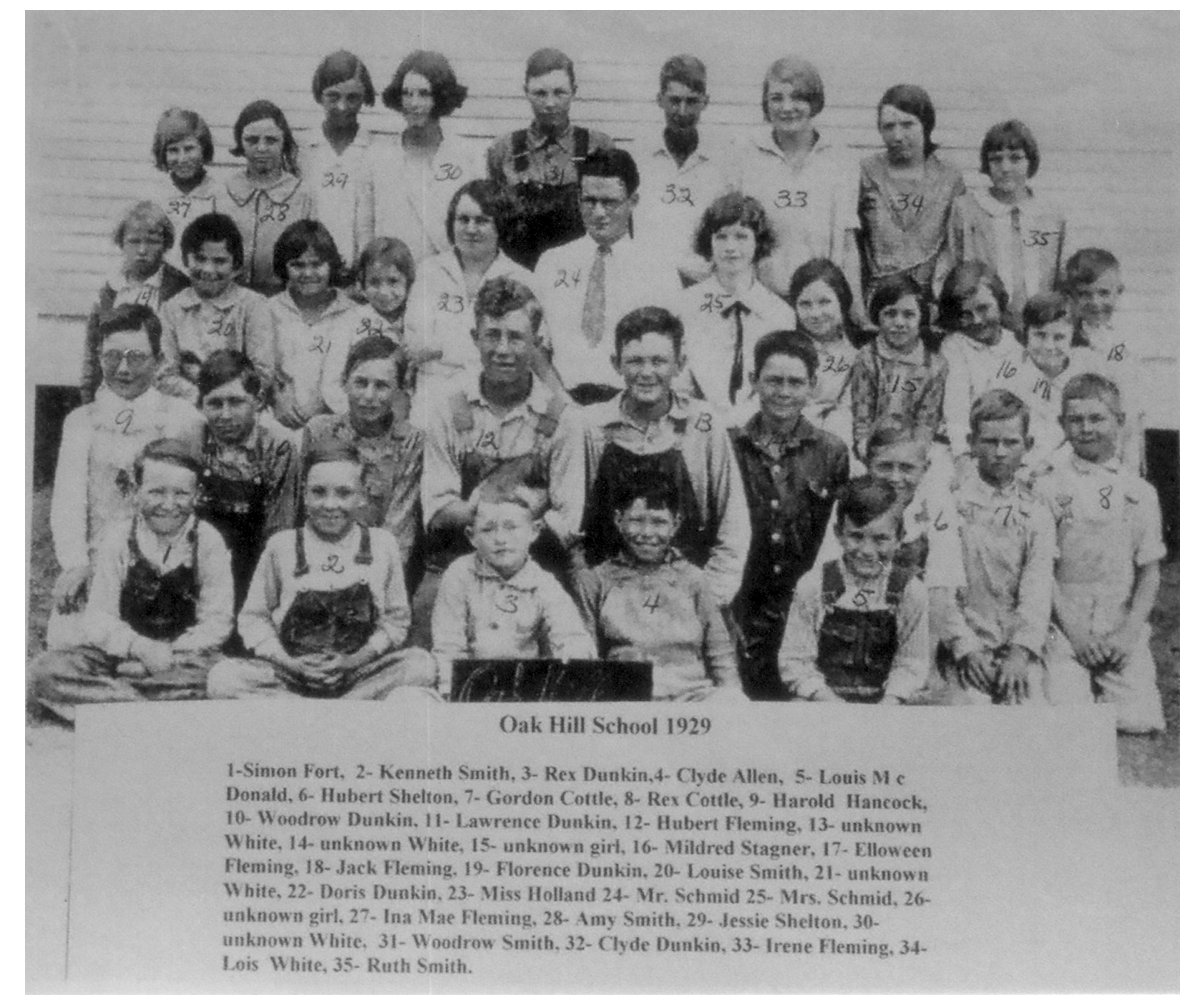

Figure 3-30. 1929 photograph of Oak Hill School students, showing several of the Camp Swift Oral History Project interviewees and/or their siblings (Louise Goerlitz).

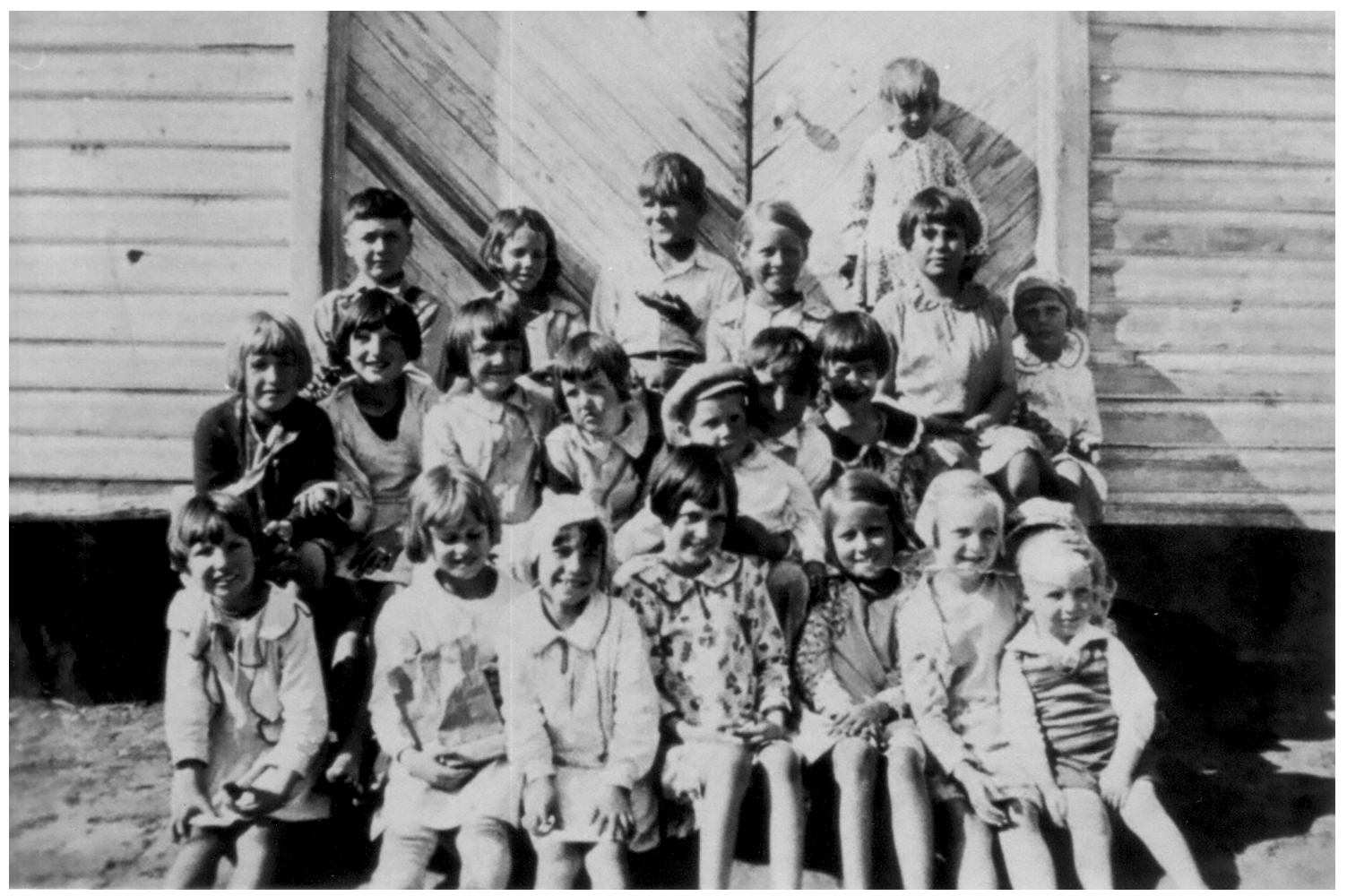

Figure 3-31. Oak Hill students outside school, 1932 (Jonathan Fleming). 
Halloween program to try to pay for it. School children put on a show for a large audience, while ladies sold roasted peanuts, sandwiches, sodas, and coffee, and an angel cake was raffled off to visitors from McDade, Elgin, Bastrop, and even farther away. ${ }^{186}$

Four rural schools operated in or near the 87 square miles of countryside in 1934, the year of the state's general school survey. Most children hiked or rode to Oak Hill School on the east (43 students, three teachers), Wayside School to the northwest ( 8 students, one teacher; Figures 3-32 and 3-33), or the all-black Sayers School on the southwest (71 students, three teachers). A few students also attended black and white one-room schools in Piney Common

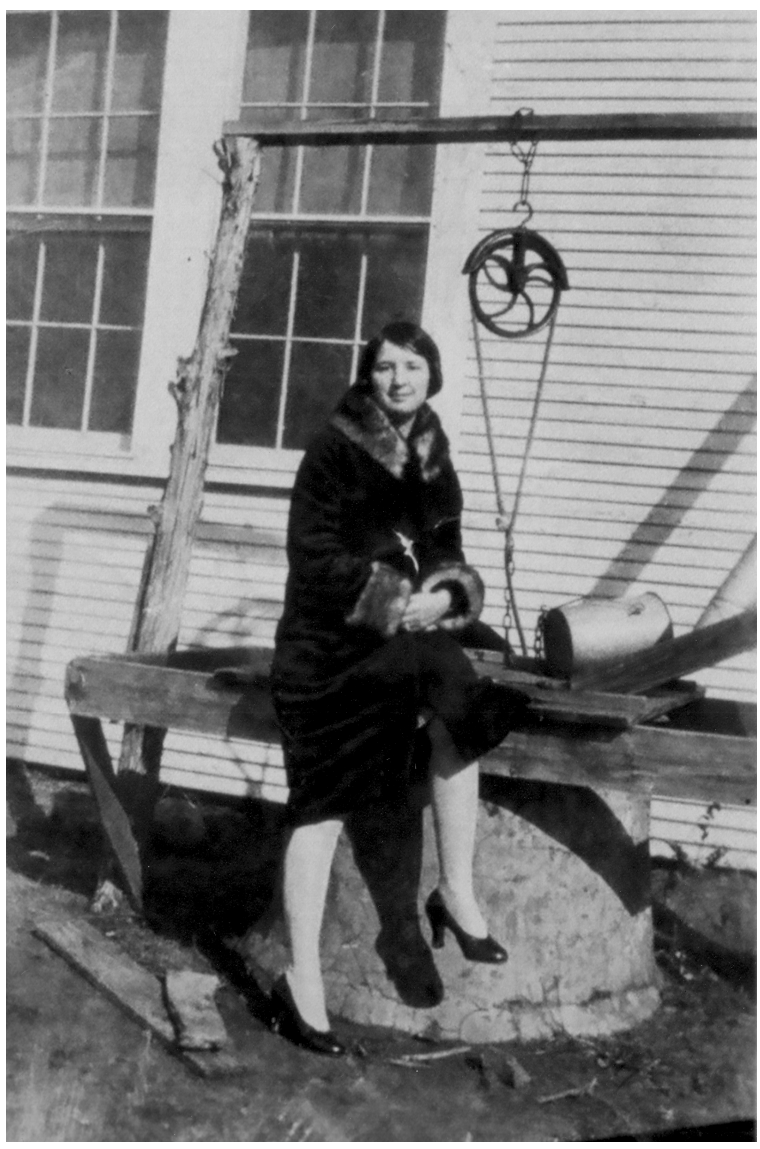

Figure 3-32. Schoolteacher Mayme McCright at Wayside School, sitting on the cistern, 1927-1928 (Jonathan Fleming).
School District, just north of Highway 21. ${ }^{187}$ Both Oak Hill and Sayers had recently grown to become three-teacher schools, but Wayside was on the decline. Abner Scott entered the first grade at Wayside in 1929, and so many students moved away from the district at Christmas that Abner found himself alone. The teacher roomed with Abner's grandfather John Scott, just as Abner did. On good days teacher and student walked the mile down the road to the Wayside schoolhouse; on bad days she held class for Abner in her rented room at the Scott's. "So, we did that, and I enjoyed that school better than anything in the world," he recalled. ${ }^{188}$

Abner Scott and other interviewees had much to say about problems getting to and from

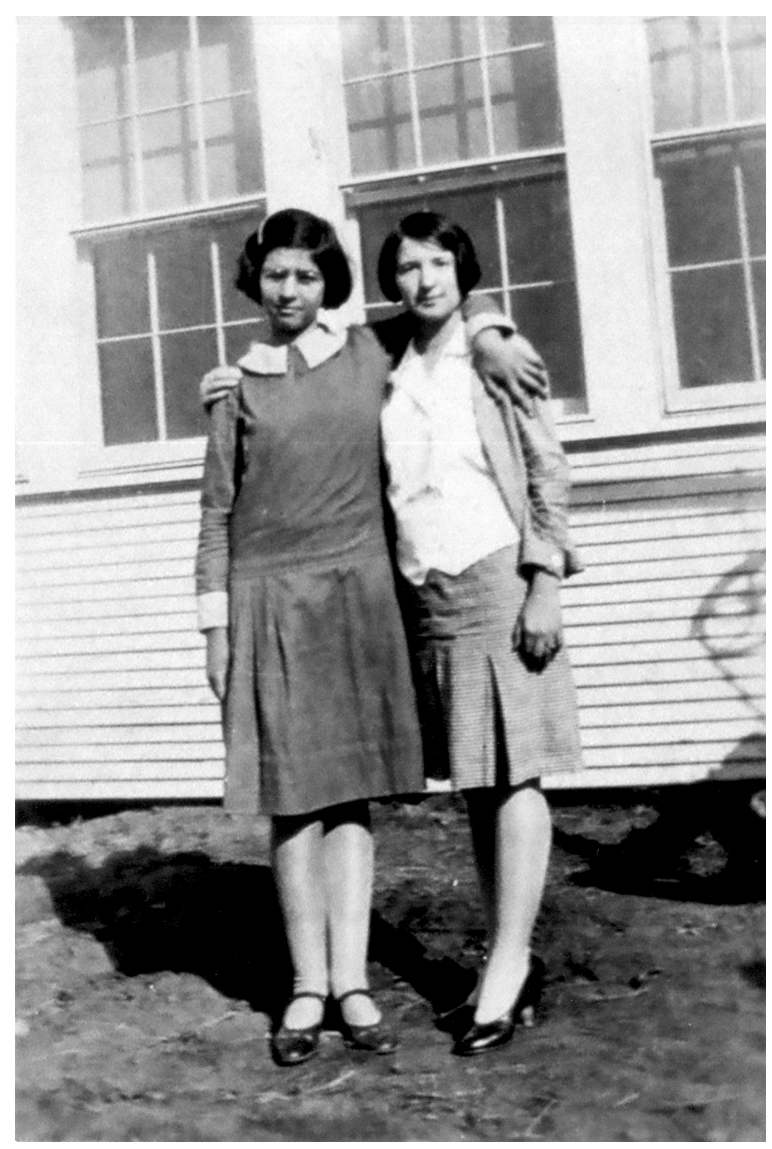

Figure 3-33. Oleta Scott and Mayme McCright at Wayside School, date unknown (Jonathan Fleming). 


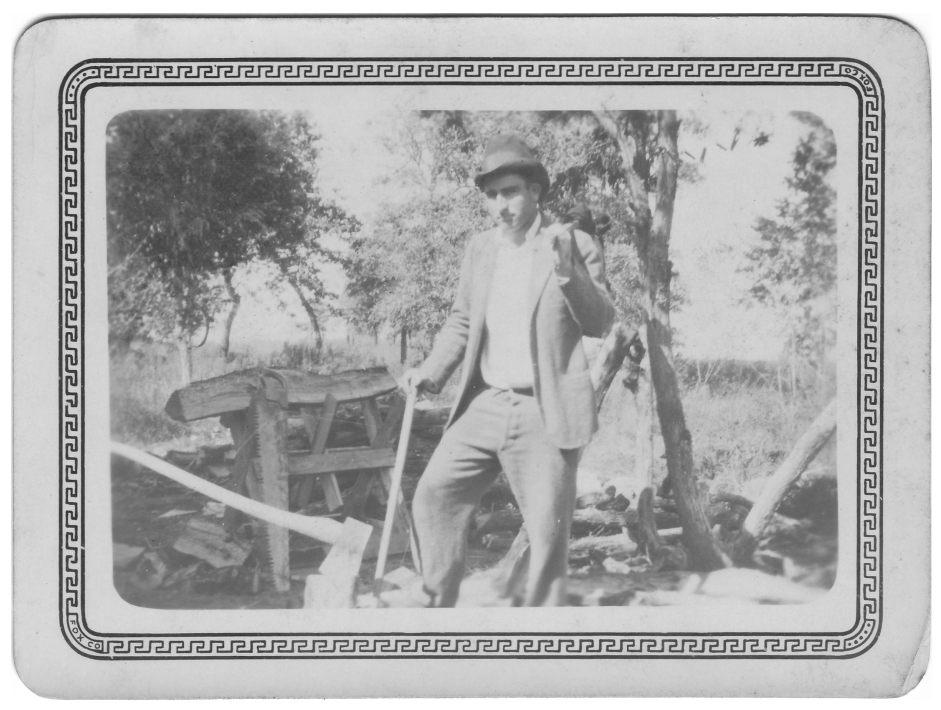

Figure 3-34. Mr. Powell, schoolteacher at Oak Hill School, cutting wood at the woodpile, 1930s (Fay Owen Pannell).

their schools. Many students had miles to travel, roads were bad, and creeks often flooded. To reduce distance traveled, children often walked bee-line trails cross-country to school, crossing various people's properties, fording creeks, and climbing barbed-wire fences as they came to them. Irene Fleming told, "By the time you'd walked two or three miles your feet were wet, you were cold. Some kids gave up, but my dad saw that we never gave up." Irene recalled crossing many barbed-wire fences, "and time you got to the school half your clothes were torn off." Piney Creek cut the Flemings' route to school, and high water on Piney might block them from attending. If the creek got up during the day, Irene's father rode to get them, taking one child behind him on the saddle across the creek at a time. If this became too dangerous, the Fleming children spent the night with friends on the Oak Hill side of the creek. ${ }^{189}$

The trip back and forth to school could be a lark or a nightmare, depending on the weather. As teachers well knew, many children did not have sufficient clothing for really cold weather. Teachers consequently felt obligated to reach the school early and start the big woodstove for the half-frozen students that might show up (Figure 3-34). The Owen children had shoes for their trek in to Oak Hill but often chose not to wear them. "If you wore shoes to school when there's frost on the ground, you was chicken," Fay Owen recalled. "You went to school barefooted with frost on the ground. That's all they could afford to buy for us, one pair a year. They had to last." 190

The Owens wore "clean work clothes" ${ }^{\prime 191}$ to school, as did most other students, but a lack of proper clothing kept others from school attendance. Young May Belle Miller had only two dresses, and "I'd take out of school one day and wash and iron "em." Once, May Belle made two new dresses from white feed sacks, dying one pink by boiling it on the stove with a brother's red sweater, and dying the other one brown by boiling it with tree bark. ${ }^{192}$

Sometimes hard luck dogged a family's educational efforts. Young Louise Smith suffered a copperhead bite just before her first year at Oak Hill School, made a poor recovery, and was judged unable to walk the necessary two miles "in the wet weeds and grass." The next year, probably 1929, Louise entered school, but her parents pulled her out after some children at Oak Hill came down with flu. The Smiths feared that Louise might catch the disease and infect her eight brothers and sisters, as everyone still recalled the deadly influenza of a few years before. Despite her troubles, she did manage to graduate (Figure 3-35).

Traveling through "wet weeds and grass" in the dead of winter might also result in the 


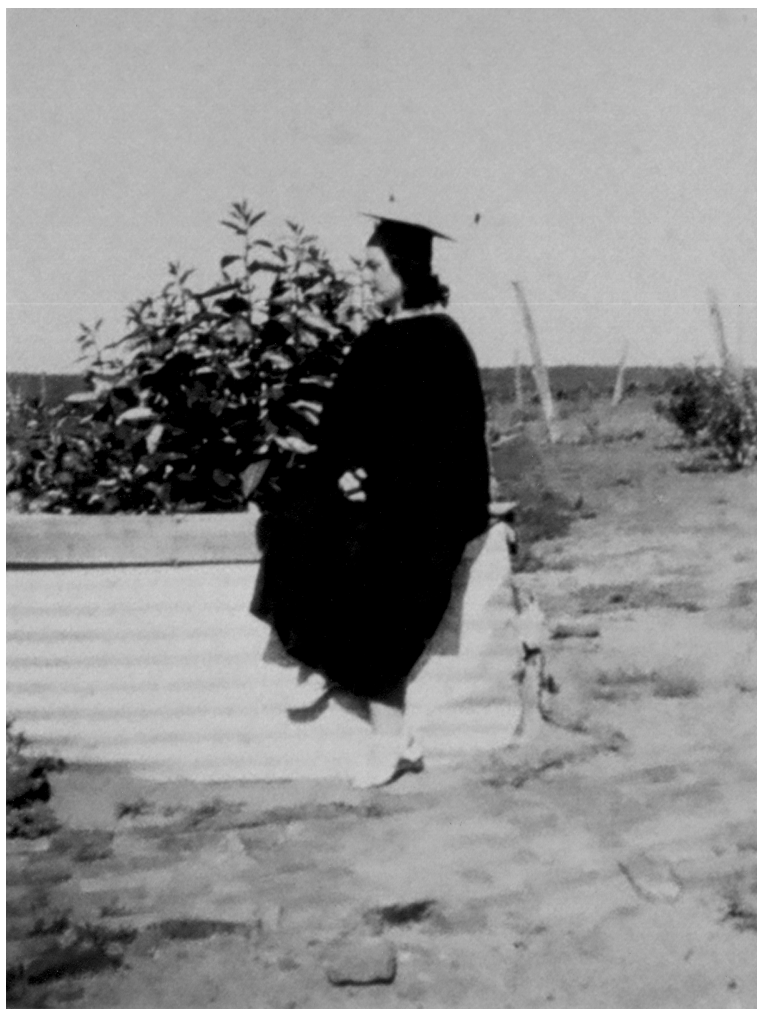

Figure 3-35. Louise Smith at the homeplace in graduation dress, 1940 (Louise Smith Goerlitz).

dreaded pneumonia, many parents feared. Pneumonia before antibiotics killed all too often. Louise Smith's great-grandfather fought through the Civil War, walked home to Bastrop County, and then died from pneumonia after saving Louise's grandmother Lizzy Stagner (Figure 3-36), who had been trapped at school by a big rain. The Civil War veteran, survivor of many a deadly battle, "waded and got my grandma from school, carried her on his back and waded through the water again," then sickened and died. ${ }^{193}$

Conversely, in times of good weather, children's trip to school could become a traveling play-party, with neighbor children joining in along the way. The normally friendly Hoffman children joined the Blackwells on the way to Oak Hill. Relations were good, but one time Jacob Hoffman pinched Bettye Blackwell on the bottom and she rapped him on the head with her lunch bucket. ${ }^{194}$ The young Blackwells and Hoffmans played around and wasted time and occasionally arrived tardy at school. Once, a lady turned them in for picking dewberries on the public road. Likewise, the Miller children snacked on neighbors' peanuts, "shocked up" at the edge of fields, during their several-mile hikes back and forth. ${ }^{195}$ Boys commonly ran traplines on the way to school, and frequently arrived smelling strongly of skunk. As many people attested, skunk-impregnated overalls reeked horribly next to hot woodstoves. ${ }^{196}$

Within each family, transport to school tended to evolve over time, as children grew older and the mix of traveling scholars changed. At first, Abner Scott lived with his grandfather Scott to be close enough to walk to Wayside

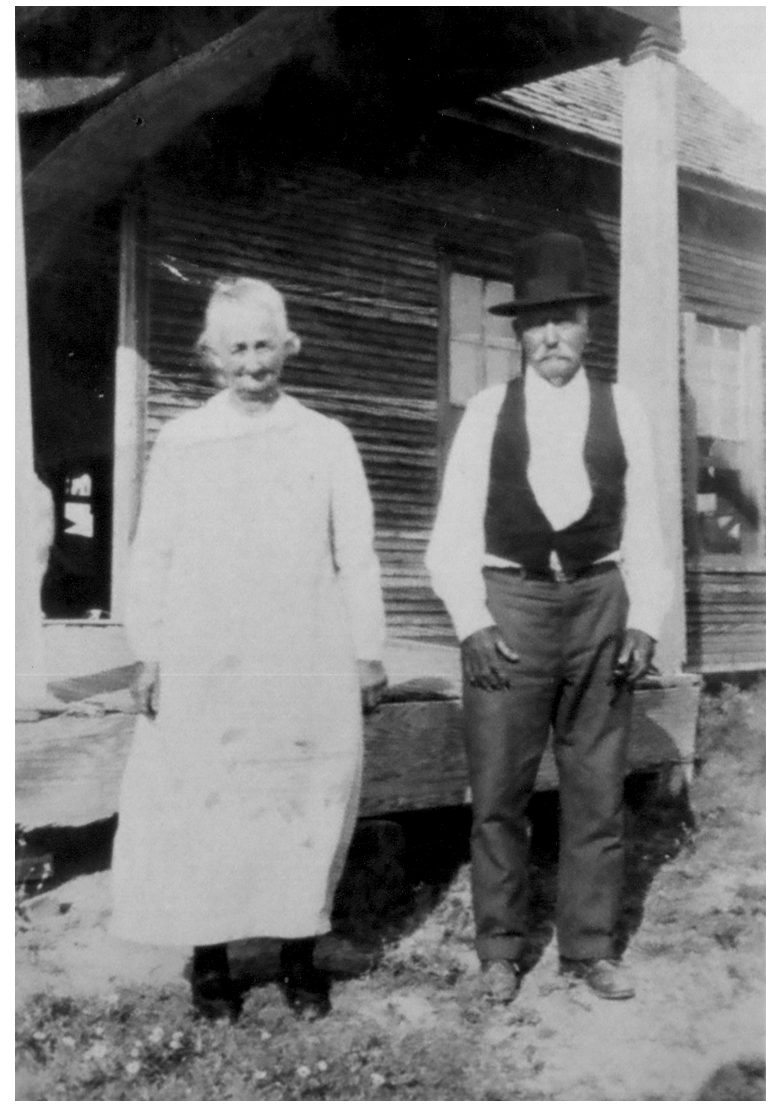

Figure 3-36. Lizzie Stagner DeGlandon and Alcide DeGlandon at Oak Hill house, 1927 (Jonathan Fleming). 
School. Then, for one year, he lived with his mother's parents to be close enough to Oak Hill. For a while, Abner and his teacher at Wayside, who rented a room from the Scotts, rode a horse together from Abner's home. Later, Abner drove a buggy several miles, transporting a different teacher, two little sisters, and younger brother Dan, the designated gate opener. Still later Abner walked several miles to Wayside School. One day, on his way home after a big rain, Abner came on his father's Model A deeply submerged in the middle of a creek. Clearly, the father had attempted to jump the creek to save his children from the flood. Fearing his father had drowned, Abner rushed to a neighbor's house nearby, only to find Grover Scott engrossed in a game of dominoes. ${ }^{197}$

Students all got to school somehow. Ruby Mae Thomas' older brothers carried her on their backs for part of the way to Sayers School, at least when she was young. ${ }^{198} \mathrm{O}$ L Flowers rode a horse four miles to Sayers, then when he grew stronger he walked; later, O L and his brother S T proudly rode a matched pair of white jennies, mother and offspring. ${ }^{199}$

O L Flowers, Irene Fleming, and several others recalled that they loved attending school, and several students excelled and graduated. Irene became a star pupil at Oak Hill, and did not miss a single spelling word from 1924 to 1925. After attending through the usual eleven grades, she then spent an extra year taking advanced instruction and serving as teacher's assistant. Each teacher dealt with several grades in the classroom by a complex cycle of seatwork and up-front recitation - an instructional juggling act of grades and subjects (Figure 3-37). Students

learned basic skills very well in excellent rural schools like Oak Hill and Sayers - if they could attend them often enough. Sometimes cotton picking lasted into December, and thinning and weeding corn and other crops began in March.

Discipline was not often a problem on these multi-grade schools, which operated rather like extended families. Older brothers and sisters took charge of siblings, teachers whipped infrequently but whipped as needed, and all across rural Texas "a whipping at school meant a whipping at home." Not that rural school children behaved like angels. Oak Hill School in Irene Fleming's day had a special problem; two families of students, all boys in one case and all girls in another, remained in a state of constant feud, with periodic outbursts of trouble and disciplinary response. ${ }^{200} \mathrm{O}$ L Flowers loved attending Sayers School and liked his teachers, but he also held them in awe. One "had a strap about that long and had holes in it, and I mean she could hit, too." The other was "left handed, and she tell you to do something you better do 
it or get that left hand on you." ${ }^{201}$ According to school-kid belief, left-hand licks hurt more.

A few children reacted badly to school teacher disciplines. Violet and Pansy Smith often walked by the Owen place on their way to Oak Hill School, and Elgitha Owen happened to see the Smith girls pass by one morning with their young brother Thurber on his first day of school. An hour or so later Elgitha observed Thurber striding rapidly toward home, repeating over and over again as he passed, "I ain't going to no goddam school! I ain't going to no goddam school!" Nor did Thurber ever go back. ${ }^{202}$

\section{Sports}

Baseball ruled the playgrounds of rural schools at the turn of the century, joined somewhat later by basketball (Figure 3-38) and volleyball. Football remained a town phenomenon. Rural students played rough at recess, but when teachers arranged visits from other rural schools for competitions on Friday afternoons they "went at it tooth and toenail.". 203 Fair Oaks School and Cedar Creek School sometimes traveled to Oak Hill for these Friday afternoon contests. Country baseball in particular was played tooth and toenail, no matter that players sometimes had to make their own bats and balls. Gloves were not a problem; only sissies needed such things. Jonathan Fleming's grandfather Curtis Fleming, recently graduated from sixth-grade at Oak Hill School, once was lured from behind his father's plow by the siren song of a distant school baseball game, walked over to join in, and received a beating from his father. According to Curtis, baseball at Oak Hill had Pannell). been almost a local obsession. Oak Hill had produced one wonderful pitcher by the name of Lonnie Smith, who once broke Curtis's ungloved hand with a fiery fastball. Many years afterward, Curtis Fleming told Lonnie Smith's son, "Your daddy had a ten-cent brain and a million dollar arm, the way he could throw that baseball.".204

Not surprisingly, many local people turned out to watch school athletic contests - even baseball and basketball games played at recess. Rural schools served as entertainment centers for their communities, a fact that schoolteachers forgot at their peril. Teachers that failed to produce good programs at Christmas and school-closing time might not be rehired. All former Oak Hill students interviewed recalled elaborate schools programs at Christmas with candle-lighted trees, refreshments, songs and skits, and gifts of fruit, nuts, and candy for every school child, but only Polly Owen's weekly column revealed the full extent and complexity of Oak Hill's yearly round of school entertainments. Students there must have been perpetually in training for the next public

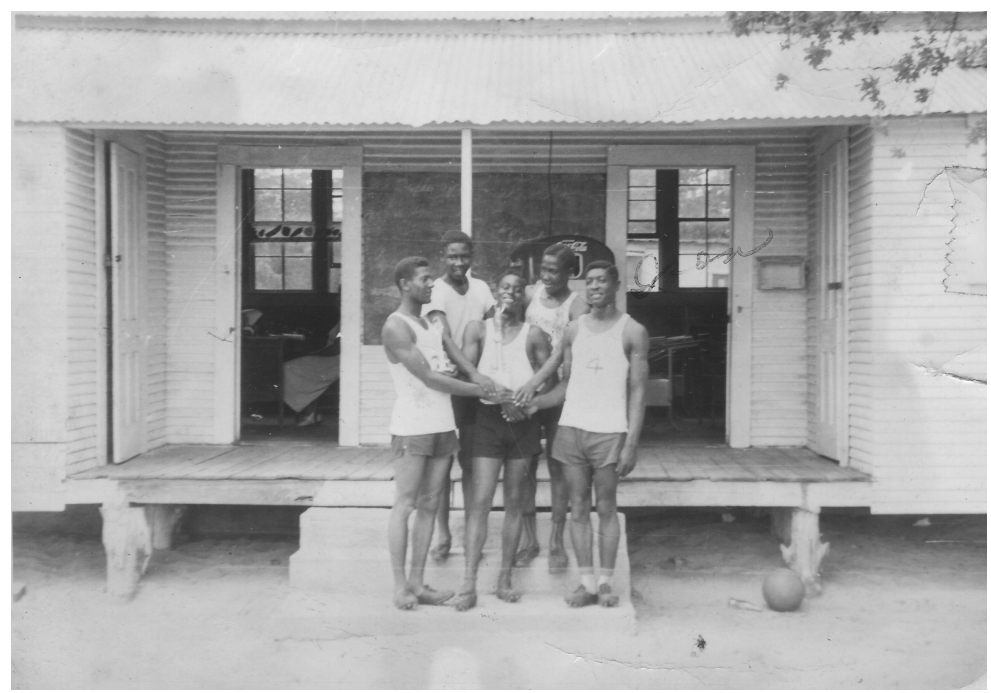

Figure 3-38. Sayers Colored School basketball team, 1951 (Fay Owen 


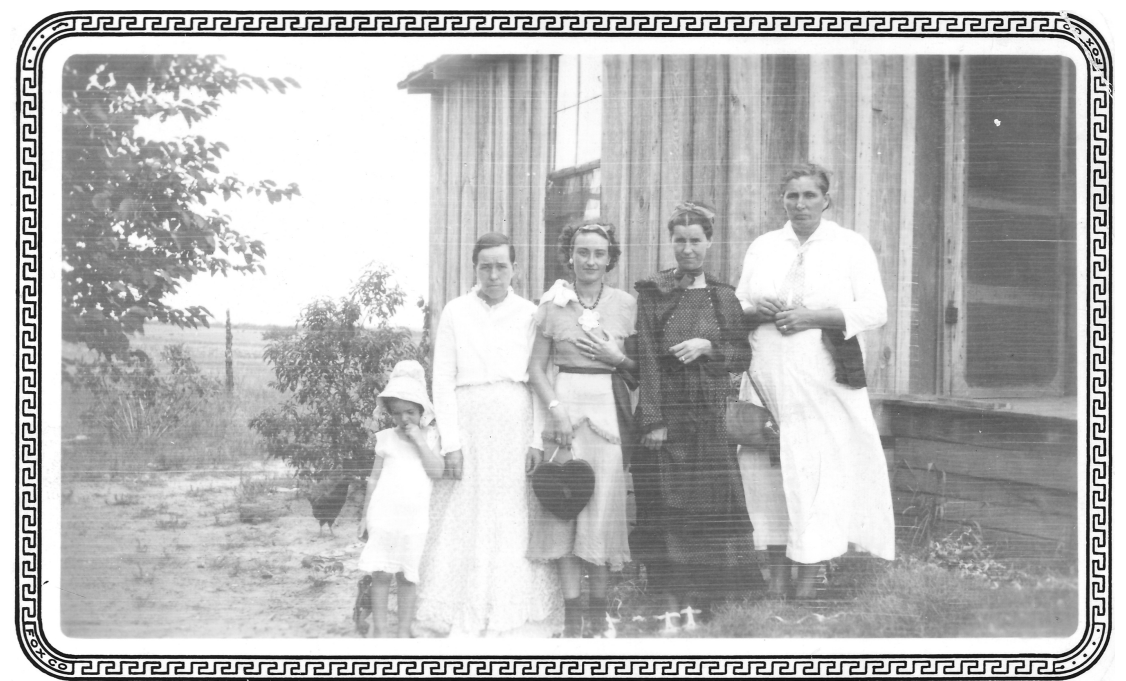

Figure 3-39. Oak Hill women dressed for a "tacky" party, 1939 (Fay Owen Pannell). Left to right: Joyce Stagner, Elgitha Owen, Fay Owen, Mrs. J. O. Stagner, Mrs. Minnie Shelton.

parties due to hard work, the difficulties of travel, and her father's attitudes. ${ }^{206}$ Gertrude Dunkin attended a few such affairs at the Wayside community: "I remember we'd go in a wagon over there to parties. I guess we didn't have any better sense." ${ }^{207}$

House parties went by various names, depending in part on how much music, dancing, and dance-like activities the host family allowed.

extravaganza. Oak Hill had special programs at beginning of school, Halloween, Thanksgiving, Christmas, Easter, Valentine's Day, and school closing, and Sayers School did much the same. Box suppers and other special affairs to raise money (such as Oak Hill's "tacky parties") might occur at any time (Figure 3-39). ${ }^{205}$

\section{Parties}

Weekend parties at private homes were the most common social events on the sandylands apart from affairs at the schools and churches. Most house parties took place at night on the weekends, with the focus on young people. These parties served as a spot for courting (Figure 3-40). There were many variations, but in general boys and girls engaged in whatever action there was inside (dancing, singing, playing ring games), older women sat around inside and watched them, and older men socialized together outside in the dark. Fathers controlled their children's social life, and some kept it at a bare minimum. Irene Fleming recalled only a few house
The Cottle family sometimes hosted "play parties" in the large cedar-floored room in the Coulson house. It was a great room for dancing, but nobody danced there. The Cottles put out the word about their party during the week

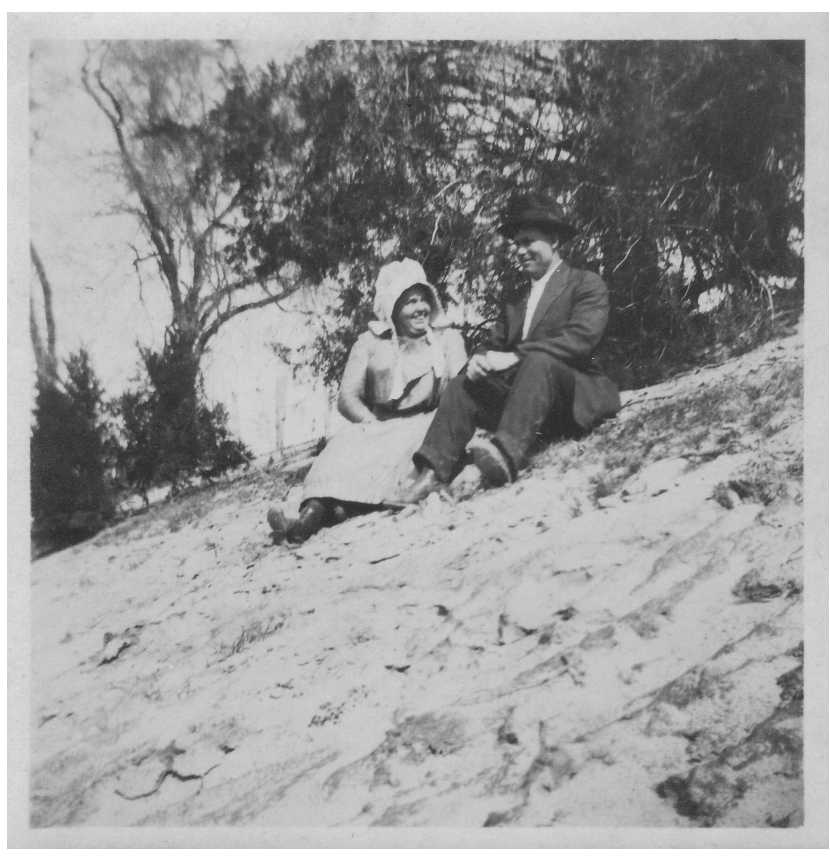

Figure 3-40. Polly and Edgar Owen during their courtship, date unknown (Fay Owen Pannell). 
before, always on a "come one, come all" basis. Anyone who wanted to participate showed up for singing, games, and refreshments, but not to listen to musicians or to dance. ${ }^{208}$ "Ring parties," mentioned by Ruth Smith and Fay Owen for Oak Hill were of this same general sort, though slightly more liberal hosts allowed such ring- and square-play movement games, often performed only to human voices. ${ }^{209}$ At "house dances," "country balls," and what African Americans called "Saturday night suppers," hosts went all the way, arranged for musicians, and allowed actual dancing to live music.

Born around 1890, Annie Hardin recalled attending "country suppers" held at African American homes in the Sayers area. Sometimes participants danced outright at these affairs, but sometimes they marched about the room twoby-two, a practice which some folk theologians believed stopped short of actual dancing. Most Baptists would not dance, but some would march to music. Families took turns hosting suppers on Friday or Saturday nights. As Annie Hardin explained, food was especially important to these affairs. "Someone would kill a hog or goat or chickens and sell plates of food. You could have all you could eat for fifteen cents." Music was provided by a local musician - guitarist, fiddler, or even "French harp" (harmonica) player. "We would all be dressed to death, like we was going to church." Girls wore their best dresses, ruffled aprons, and high-topped shoes, though they might take off the shoes to dance barefoot. "If a boy walked up to a girl and got her to march with him, after the dance he had to treat her - give her candy or an apple or something. We would go home with an armful of stuff." Boys saved money all week to go to the dances. At age 16, Annie met Sandy Hardin at a country supper, and soon thereafter they married. ${ }^{210}$
Walter Thomas generalized about these "Saturday night suppers," perhaps wilder affairs than Annie Hardin usually attended:

There would be a lot of fun making, somebody could play a guitar or somebody could play a fiddle, a fiddle man. They had a lot of spirit, then. People could sing, they could beat a tub. That old African rhythm in them, it was still there. They'd make their own little drinks, that old beer and little bootleg whisky or whatever you want to call that old stuff — some kind of liquor to make them have fun. ${ }^{211}$

While Jim Crow rules and dictums lay less heavily on the north Bastrop sandylands, blacks and whites held separate house parties. Only star black musicians like Mance Lipscomb of Washington County might sometimes be recruited for white house parties, though perhaps not so far afield as Bastrop County. ${ }^{212}$ Good musicians of whatever race were at a premium, however, and anyone who played an instrument moderately well received invitations to perform.

\section{Music}

Musical talent ran in families, as in the case of the Millers and Blackwells. Mr. Miller had mastered the fiddle and the "eight note accordion," and often sang along with the latter instrument. Ten of Miller's twelve children were musically inclined, and had picked up fiddle, guitar, mandolin, and accordion playing with ease (Figure 3-41). Various groups from the big family often performed at country dances. The constant home practice occasionally got on the nerves of the two of May Belle Miller's brothers who were not in any way musical. She was practicing her accordion early one morning when an exasperated older brother rose from his bed, took away her accordion, and-as a 


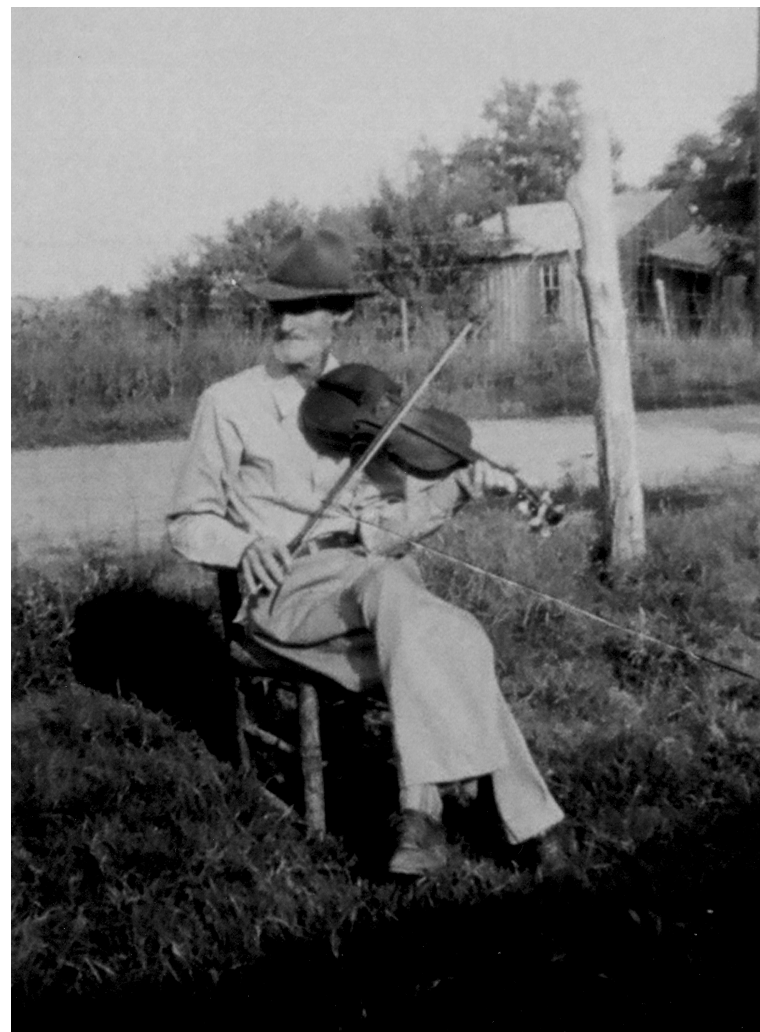

Figure 3-41. Jepp Hill Miller with violin, date unknown (Verna Morriss Vandervort).

gesture of protest - briefly placed it on top of the hot woodstove. ${ }^{213}$

Willie Blackwell and two of his three children, Leola and George, also mastered several instruments, and often played for house dances in the Oak Hill area. Bettye (who did not play) remembered:

Daddy played the accordion and Leola the guitar and George the fiddle, and they would practice on the front porch. After Leola got older, the three of them played for house dances in the community, where a family would take all of the furniture out of one room to dance, a different place on Saturday night, and during the night time a hat would be passed around. ${ }^{214}$

George also became very accomplished on the guitar. He learned all he could from his uncle Arthur Strong, then took occasional lessons from a male visitor to a black neighbor's wife. This fine guitarist, a man, appropriately known as "Wolf," "was in and out of prison for shootings and cuttings, but Daddy never said he couldn't come and sit on the front porch." The Blackwells honed their musical skills and repertoire as best they could. George and Leola often learned new songs from the family's treasured battery radio, though "it might take two weeks of listening to a song to get the word right." Favorite programs were Nashville's Grand Ole Opry and WOAI San Antonio's Chuck Wagon Gang. ${ }^{215}$

Willie Blackwell expertly played two different sorts of accordions, playing by ear. He could not read music, and was entirely selftaught. Willie also played a wonderful "French harp" or harmonica, performing "loud and from the heart." His children loved to hear him sit on their front porch and expertly mimic the wailing steam whistle of the passing "Katy" train. "We could sit on the front porch and hear it coming around the bend," Bettye remembered. "We must have been three miles away from the track, but it was quiet back then. If our clock had stopped, we could set it by train." 216

\section{Visiting}

House parties took place fairly often, but no countryside social event occurred so commonly as the casual visit of one family to another. Once, the Blackwells received an after-dark visit from their friends the Strongs. Bettye Blackwell described:

When John Arthur Strong was a little boy, they drove down to our house, about 1937 was that year, and that night we were completely out of kerosene and was sitting on the porch in the dark, and when they came in they struck a match to see how big he was getting. We just 
sat and visited in the dark. No candles, no nothing. ${ }^{217}$

For anyone but a near neighbor, the casual come-and-go visitors like the Strongs were a modern development, linked to the automobile age. Earlier visitors had come by wagon and expected to stay overnight or for several overnights. Minerva Stewart, a black neighbor and friend of the Blackwells, for example, had an emergency bed in her bedroom stacked with six mattresses, five of them ready to throw on the floor to accommodate visiting kinfolk or friends. ${ }^{218}$ Most visitors expected that you would be happy to have their company, whether they had warned you of their arrival or not.

They usually assumed correctly. Families living in the remote countryside were starved for company, and any visitors offered amusement. A variety of peddlers depended on this rural boredom and its counterpart, hospitality. On one occasion a magazine subscription salesman visited the Blackwells at the end of the day and traded Mrs. Blackwell, an avid reader, a subscription to Progressive Farmer for a night's room and board, no matter that one of her daughters had to be put from her bed. ${ }^{219}$ Ruth Smith recalled "Old Man Bright," who drove a buggy out from Lexington, Lee County, peddling grape, pear, and peach cuttings from house to house. He stayed at various houses while he traveled around the countryside, a sort of guest/peddler/pest, all combined. Another man went around in a horse-drawn hack fixing sewing machines in rural Bastrop, Lee, and Travis counties. He traveled from house to house inquiring about any needed sewing machine repairs or adjustments, performing these for a small fee, then at the end of the day "he'd stay at somebody's house and fix their machine free of charge." ${ }^{220}$
Some family to family visits related to work, with visitors arriving to help with some task that many hands made light labor of, thus setting up the expectation that in time the host family would reciprocate. People came over to assist with hog killings, corn cannings, crop workings, and (in earlier times) house buildings, "log rollings," goose pluckings, and quiltings - combined work events and social occasions. Mary Lou Reese well expressed the social dynamics of all these neighborly work occasions in her recollection of swap work for chopping weeds:

Them kids over there at that house, lived way up there, they had a farm, they'd come over and help us chop awhile, and we'd take our hoes and go over there and chop, and we'd chop and sing and talk. We'd go over and help them wipe out that spot [of weeds], then they'd come over here and give us about that much time. We'd sing songs we don't sing Sunday at church, just singing and enjoying it. ${ }^{221}$

People enjoyed this sort of work occasion-especially in earlier times. Leola Blackwell's mother-in-law told of a woman that loved quilting parties so much "she would set the clock so the men would come in from the field early to eat lunch. She would call 'em in so she could go off to her quilting party." 222

\section{Roads}

Although by the 1920s automobiles greatly facilitated visits from family to family and visits to town, local roads remained poor. "The roads was just little old trails going through the pastures and around the fence lines," Morris Kastner disparagingly recalled, and by this he meant all roads. Several people remembered Saturday evening drives over to neighbors to listen to the first-generation battery radios 
for the Grand Ole Opry. Jack Scott and his family visited the Will Evans family, who had "one of them RCA Victor Radios with a big speaker, a round speaker. It had one of them great big old batteries, they couldn't many people afford that." Roads around 1930 were, according to Jack, "in fair shape, but you best stay home when it's raining. The mail carriers had some problems." 223 The Blackwell family also traveled several miles to a neighbor's radio so that Willie Blackwell could listen to Joe Lewis fights, but trips back were prolonged and unnerving. Roads were rutted and bad, and the Blackwell family's Model T pickup had no functioning headlights. ${ }^{224}$

Fay Owen recalled bad, poorly-marked roads all around and between Oak Hill and Sayers - anywhere off the major highways. Local roads alternated between deep sand and slick clay, and the sand was treacherous when dry and the clay when wet. Fords across creeks were always a problem; some drivers tried to creep across them in lowest gears, some ran at them at high speed and tried to "jump" them. From time to time, neither approach worked and the car ended up stranded at midstream (Figure 3-42). The driver often drove in deep ruts, listening anxiously for a car coming from up ahead. Ruts might be so deep that cars meeting each other were like trains running on the same track; somebody would have to back up until he could escape the ruts. Fay's friend broke a wheel on her Model T while desperately trying to escape deep ruts to let a honking salesman's car pass her from behind. ${ }^{225}$

\section{Trips to Town}

Despite the roads, automobiles meant that family trips into town, Bastrop or Elgin, had become somewhat more common. Fay Owen spent her later school years commuting into Bastrop in an open touring car, which was bitterly cold in the winters. Fay disliked the attitude of Bastrop youths toward "poor dirt kids" from the country, though some of her brothers won social acceptance by their proficiency at the town sport of football.

Rural people, especially African Americans, came into Bastrop on Saturdays. Like the Blackwell children, they often frequented the Saturday movies in the Strand Theater, which ran "B" westerns, serials, cartoons, and other youth fare for nine cents a matinee. Whites sat downstairs and blacks upstairs at the Strand, but both races joined forces to whoop it up "when the good guy did in the bad one."226 Town dwellers seemed to have left downtown Bastrop somewhat to rural visitors on Saturdays, at least in Fay's opinion. "Saturday was colored people's day in Bastrop," she noted, "and the town people didn't go up there much, cause there was all those colored folks in town." 227 One of these people was young Mary Lou Reese, who

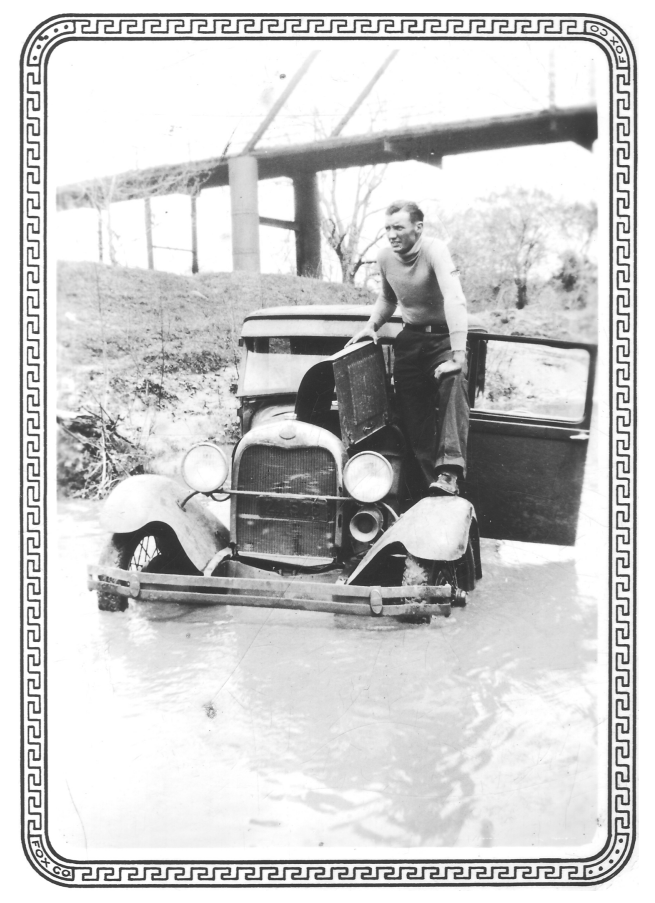

Figure 3-42. Perry Mills, a CCC camp boy, and his Model A Ford stuck at an old wagon crossing in Piney Creek, 1934 (Fay Owen Pannell). 
recalled leaving by wagon very early to reach Bastrop in time to do anything. "I didn't go too many times, but it was just a big gathering and the happiness of the day, going up and down the street." 228 Many African Americans visited the county seat only rarely. O L and S T Flowers "didn't go to town, 'cause we didn't know nothing to go to town for." 229

Bastrop might have been amusing to visit, but it was a strong dose of Jim Crow segregation for some rural blacks, who were accustomed to looser racial relationships back on the sandylands. Fay Owen and her four brothers had grown up playing with the Flowers brothers, $\mathrm{O} \mathrm{L}$ and $\mathrm{S} \mathrm{T}$, who sometimes amused themselves by coming over to track Jack Owen around the countryside. Barefooted Jack had an unusual, short-toed footprint, which made him easy to track. ${ }^{230}$ Presumably, the Flowers and Owen children never went into Bastrop as a social group to confront Jim Crow norms. However, growing up in "the wilderness," as she called it, Ruby Mae Thomas and her innocent brothers once did just that. The black Thomas boys and the white Moon girls, who lived with their family nearby, had grown up as close friends. "They had beautiful girls, and my brothers thought we were all sisters. We played together, and if we fell out on a pallet they'd fall on the pallet and we'd sleep." The two sets of children visited each other, ate meals together, and one memorable Christmas they went into Bastrop together. "So, we went to town, all of us was together, and oh, man, like to been a stink! Those white boys wanted to whip my brothers." ${ }^{231}$ Black boys and white girls in a social group was too much racial togetherness for the courthouse town.

Willie Blackwell preferred to use his Model $\mathrm{T}$ for transport to countryside sporting-life pursuits - fox and wolf hunts, greyhound races for rabbits, and rooster fights, but he occasionally took his family into Bastrop. Traveling to town down the new hard surface Highway 95, probably around 1940, cars were flying down the highway while Blackwell drove the family pickup in the roadside bar ditch. "Daddy told Mama, 'God, Ethel, look at them go!"” Later, Willie mastered hard-surface driving, but the Model T topped out at only about $25 \mathrm{mph}{ }^{232}$

\section{Social Hunts}

The social hunts that Willie Blackwell so enjoyed usually involved only men and older boys. For fox and "wolf" (coyote) hunts, Willie, Curtis Fleming (Figure 3-43), and others drove their cars into the deep countryside, more often than not the unpopulated sand hills of the Alum

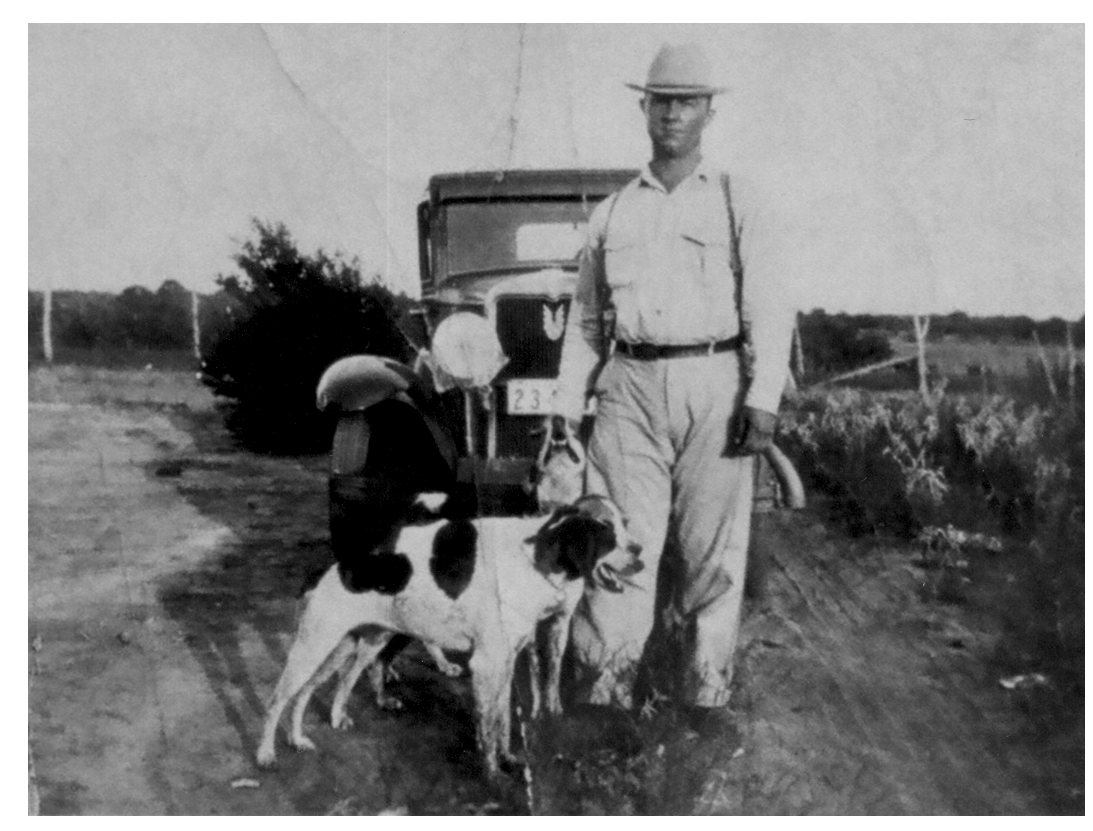

Figure 3-43. Curtis Fleming with foxhounds, date unknown (Jonathan Fleming). 
Creek drainage, released their foxhounds from cages to begin their hunt, built a fire, and stood around in the dark listening to the hounds run their prey. That was it; the men vicariously competed with each other through the voices and performances of their dogs in the chase, which they followed entirely by sound. Grey foxes were easier to catch, but either a red fox or a coyote had the ability to run a foxhound to death. Other men sometimes came out from McDade and Elgin to run foxes on Grover Scott's land, and none of the fox hunters wished for the foxes to get hurt. At the end of the chase, red foxes went into holes in the ground and grey foxes climbed trees. "Some of the town people, I call 'em town people, from Elgin came down to our place just to run fox," Abner Scott said, "and they never did kill them unless that silly fox decided to jump out with all them dogs down there." ${ }^{233}$

Hunting dogs were a priority for Willie Blackwell. He kept foxhounds, coon dogs, greyhounds, and beagles, and spent many nights and days away from home in their use. Dogs all had resting holes in the yard, with precious water poured in during the hot summertime to cool them off. As did all dog men, Willie mixed his own dog food every day from skillets of cornbread, table scraps, and left-over cooking grease. Blackwell dogs also consumed a lot of milk from the prize dairy stock inherited from Willie's parents. "We kids could have gone barefoot, but his dogs were going to get their worming and distemper shots," Bettye Blackwell admitted. Willie's mother often came over on the holidays to see her favorite son, but she usually found him gone with his dogs to Three Rivers, George West, Eagle Lake, or somewhere else. "I can never remember an Easter or Thanksgiving that he was at home." Fox hound competitions were for bragging rights, but greyhound chases often were for money. Greyhound competitors moved out across a field with their leashed dogs, followed by a crowd of other men - gamblers and onlookers. After a sitting rabbit had been sighted some distance away, people made their bets about which dog would catch the rabbit, someone jumped the rabbit in sight of the dogs, and owners loosed their greyhounds. Willie Blackwell also raised fighting roosters, sold them, and traveled far and wide to fight them and doubtless to bet on them. "A big part of Daddy never grew old," Bettye Blackwell said of her father. In later years, Willie Blackwell died of a heart attack at a chicken fight, a game rooster under one arm. ${ }^{234}$

\section{Fishing}

Unlike the social hunts, mid-summer fishing trips, picnics, and swims usually involved men, women, and children, with several families commonly traveling together to Big Sandy Creek, the Colorado River, or Bastrop State Park (Figure 3-44). Fay Owen's family, Abner Scott's family, and numerous others made yearly trips

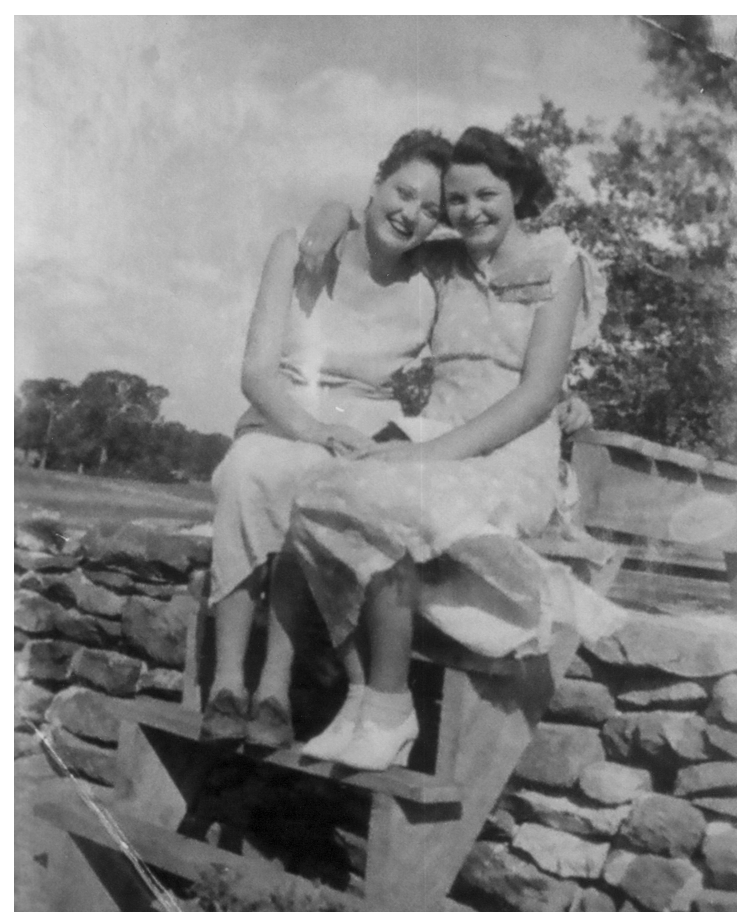

Figure 3-44. Ruth and Amy Smith at Bastrop State Park, 1935 (Ruth E. Smith). 
to the Colorado to picnic, swim, and fish, often staying for several days (Figure 3-45). Abner Scott recalled a typical trip, one like many other private fishing expeditions to the Colorado at "laid by time," after the crops had received their last weeding and cultivation:

Even in the Depression, when we didn't have a vehicle, we'd go with a wagon and team, and several families would go down to the Colorado River, which is twelve to fifteen miles from here, we'd go down there and spend the weekends or three or four nights. You could set trotlines across with several hooks on them, and you seine the bait out of the shallow part of the river, put small perch and minnows and so forth on the line, and you'd catch enough fish - you know, you couldn't save it long - but you could catch enough fish to have several fish fries. ${ }^{235}$

Other people camped out, picnicked, swam, and fished on Big Sandy Creek much closer by, often choosing the deep pool near the famous old tree known locally as the "Sayersville Elm." ${ }^{236}$ This site was fine for picnicking and swimming, but creek pools like this one tended to become over-fished until restocking by the

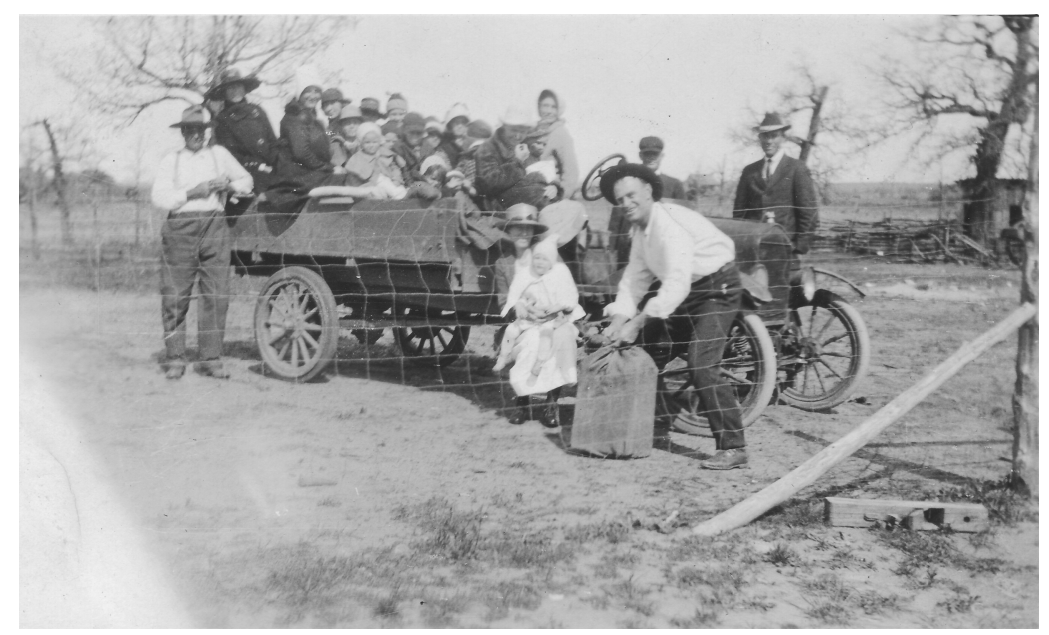

Figure 3-45. Andrew Morgan Smith family ready to leave on a picnic to the Colorado River, date unknown (Fay Owen Pannell). The burlap sack is filled with ice. next winter's high water, and some families preferred to drive wagons for miles down the banks of Big Sandy Creek, fishing as they went. $\mathrm{O}$ L Flowers and his family often did this. O L recalled:

After we got through chopping cotton, waiting for cotton picking to come in, two or three wagons would get together and follow these creeks and go fishing. And everything we caught in the morning, when twelve o'clock or one o'clock comes, we'd cook and eat what we had caught. Then, what we caught the rest of the day, we'd take it home. We'd go from one end, hit the creek up there close to McDade, and we'd come out down here at Sayers where this creek crosses the road. Bunch of us together, and we'd just travel the creeks, go swimming, fishing, hunting. ${ }^{237}$

Two or three families often got together to travel Big Sandy Creek in this fashion - men, women, and children. They slowly followed the creek in wagons, fishing from deep hole to deep hole. Boys took their .22 rifles and hunted squirrels and rabbits as they went in this combined fishing and hunting trip. The wagons left the creek from time to time to pass through known gates into the next property; nobody worried about trespass (or game laws) in those days.

The Flowers party's fishing methods varied, but the underlying rule seems to have been that recorded for the similar fishing trips of East Texan Harold Snelson's family, "If we don't get 'em one way, we'll get 'em another." ${ }^{238}$ As they traveled from creek pool to creek pool, the Flowers boys often used hand-held 
fishing poles in the usual way, but they were in something of a hurry, and: "sometimes we'd just get in the water and what we call 'muddy it up.' Get it real muddy, just get barefooted and get in there and start kicking it around, then the fish in there he comes to the top and we catch em like that." O L's step-grandfather had another method for accelerated fish-getting-green walnut poisoning. Before the trip this man prepared tow sacks full of smashed-up green walnuts, "and if there was a hole he thought was fish in it, just kind of a hole cut off to itself like, not no running water, he'd throw them in there, then them fish would come to the top when they'd get drunk off that walnut juice." 239

A few people used yet another direct method-wading the creek and feeling about in bank holes and under logs for catfish, then grabbing them and hauling them out. People called this hands-on method "grappling," “cooning," or "noodling." O L recalled: "I've seen some of them do it, but I didn't want to do that [because of snakes]. Them old catfish, certain time of day they get back in them dark places where its cool, and they'd lay there.”240

\section{Church}

The Flowers family were rarely, if ever, allowed to fish on Sundays. On Sundays and during mid-summer revivals, the Flowers family and others, both black and white, joined in formal occasions of social life based around the church. O L's mother insisted that the family travel in their wagon to attend the Methodist church at the Piney community to the southeast of Sayers. Her rule was to go to church first and always, and then $\mathrm{O} \mathrm{L}$ and $\mathrm{S}$ $\mathrm{T}$ might do something recreational. However, as $\mathrm{O} \mathrm{L}$ remembered, the church service and the long slow wagon trips to and from Piney Creek took nearly the whole Sunday. ${ }^{241}$
Black churches held services at Piney and Sayers, and the largest white congregation in the area met at Oak Hill. Oak Hill was a "union church," a community church open to all, or at least to several, Protestant denominations. Baptists, Methodists, and Presbyterians each usually assembled once a month at Oak Hill church during the years between 1920 and 1942, assuring that worship normally took place three Sundays out of four. Oak Hill church had never had a resident minister, at least within living memory, and all preachers "rode a circuit" from elsewhere. Worshipers often cared little which denomination gave the sermon on a given Sunday; the important thing was that a preacher came and held religious service. "Didn't make any difference the denomination," Fay Owen asserted, "they would just announce they were going to have church." ${ }^{42}$

Held inside in the winter, services moved outside under a brush arbor for the hot summer months. Polly Owen rarely failed to note the move back inside. During the previous week church members met to repair and clean up the church and to prepare it up for the coming winter. "The church building was scrubbed, windows washed, and the benches moved inside again." Volunteers cut weeds, hauled off rubbish, set up the wood stove, and then ate a big meal at noon. ${ }^{243}$

People appreciated their church and enjoyed helping out with it. Besides the prayer, worship, and communion, Sunday church had significant entertainment value. People socialized with neighbors before and after church, and in between they heard a trained speaker give a rousing sermon. Pillars of the community like the Hancock family often asked friends to Sunday dinner after church, and many an Oak Hill chicken died to feed such affairs. ${ }^{244}$ 
As at Piney, Sayers, and many other places, religious life peaked at mid-summer with the annual three-day revival held under the brush arbor. Different denominations organized these from year to year, competing to recruit the best-known revivalists and preachers. People came long distances to the summer revival, often camping out in and around their wagons. During the long days of revival, wagons held pallets and food for sleepy or hungry children. Even families like that of May Belle Miller, that lacked "clothes fit to wear" and did not usually attend church, got dressed up the best they could and came to the summer revivals. ${ }^{245}$

Preachers baptized converts, the fruits of revival, at the end of the three days in a nearby gin pool, which, perhaps like the muddy River Jordan, left an indelible mark. Abner Scott told of his mother:

She joined when Brother Holt was the Baptist preacher that come. I remember I was about seven years old when she joined. She was baptized over there in the Hancock Gin tank. All [steam] gins had a gin tank. She wore a white dress, I can remember it, she was baptized in the muddy tank, and it was never white again! $!^{246}$

\section{Cemetery Picnics and Juneteenths}

The Oak Hill Cemetery Association, a non-denominational group, filled the social gap left by the lack of formal congregations at the Oak Hill community. Members took care of the cemetery, held Oak Hill's famous cemetery picnic in late spring, and arranged for funerals. At news of a death, neighbors traveled to help the bereaved family by preparing the body for burial and sitting up with it all night. They also brought food so no one in the house would have to cook. Burial, more often than not, occurred the next day, and volunteers from the cemetery association took charge of digging the grave. Men and boys from large Oak Hill families alternated in performing the hard gravedigging task; the Flemings dug graves for a time, then "the Scott boys," and so on. ${ }^{247}$

The Oak Hill Cemetery Picnic in June (later held on the last Saturday in May) was the major project of the Association, and the biggest happening of Oak Hill's yearly round of events. This was even bigger than schoolclosing festivities or the school Christmas programs. The event had originated as a simple graveyard cleaning, a common Southern work occasion where community people pitched in to cut weeds and grass and to put their cemetery in order. By 1920, the event at Oak Hill had become first and foremost a community picnic - not that the cemetery was neglected. A permanent committee that still meets today supervised its year-round care and upkeep and-before the picnic - the careful mounding of fresh earth over each grave (Figure 3-46). ${ }^{248}$

Everybody well remembered the big day at Oak Hill Cemetery. Dean Fort recalled:

They'd play ball. Us kids, we just played and run through the pastures down there. When I was a kid we never missed a picnic. People'd come in there, and you couldn't hardly get down there and find a place to park, and the farmers would donate a calf, and they'd barbecue a calf right there."249

Thirty years older than Dean, Irene Fleming had very similar memories of the picnic. Children showed up "dressed to the teeth" by their mothers but soon ran wild, the fine clothes forgotten. They played and chased each other, mostly out of adult supervision and happy to see so many other children. And there were special treats of the picnic: "All I can remember is red soda water!" 250 


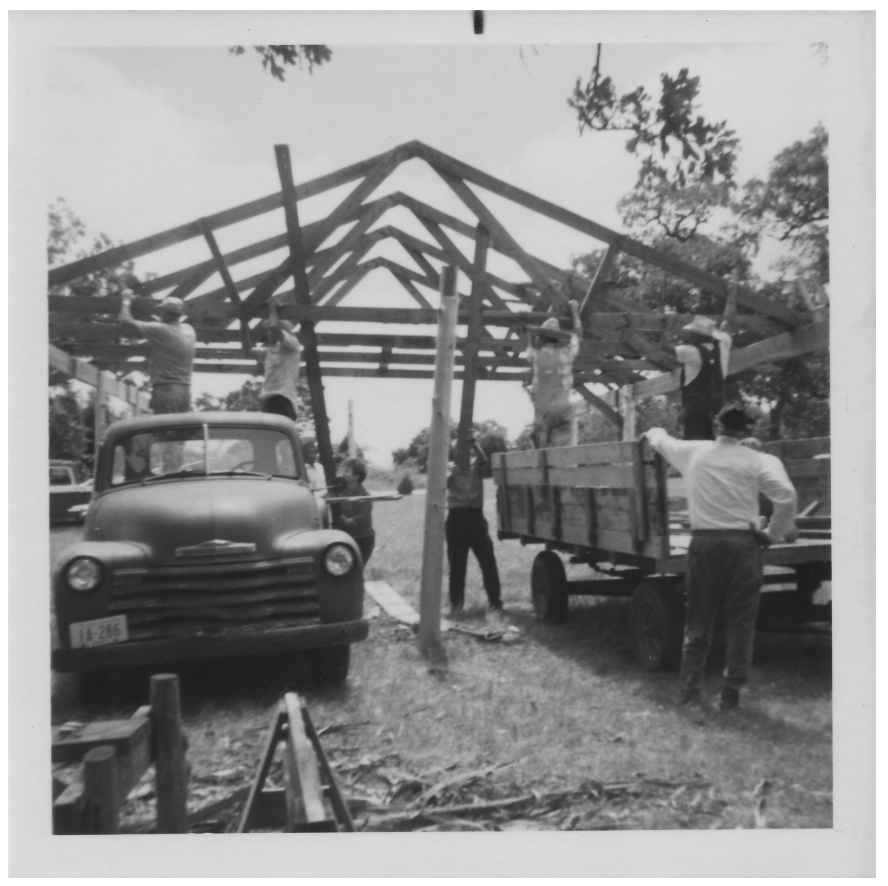

Figure 3-46. Building the arbor at Oak Hill Cemetery in the 1970s (Fay Owen Pannell). The Oak Hill Cemetery Association remains very active in 2006.

Ruth Smith, who once held the office of Oak Hill Cemetery Association president for seventeen years, remembered the event as Oak Hill's biggest social occasion. "Mother had to make us a new dress, and we had to have patent leather shoes and a black hat to wear at the picnic. It was a big social-life deal." ${ }^{251}$ The big day featured the picnic feast, where the community's best cooks competed to impress others with their best dishes. Men stayed up all the night before cooking the meat-beef barbecue - though homemade fried chicken never lost its place on the picnic tables. ${ }^{252}$

Like every other Oak Hill woman, Bettye and Leola's mother cooked all the Friday before-cakes, pies, and vegetables - with everything tied up in clean cup towels ready to go. Blackwell children attended on Saturday in their best starched clothes. In election years politicians attended and made speeches, and they might give each child a nickel for a soda water. Iced "cokes" (any sort of soda water in Southern vernacular, even the red kind) were available, and parents also usually handed out a few nickels to spend on them. Before lunch, women spread cloths over the plank boards that had been put up around and between trees for makeshift tables. Babies slept on quilts under the tables. Ruth's mother told her that a cedar-bough arbor had been built in 1916 to spread the food under, and that she had pushed infant Ruth around in a buggy in that year. At noon, each family head took a dishpan for some of the pit-cooked barbecue. All the other food had been laid out to share with all — even with the occasional family of free-loaders who had contributed nothing. ${ }^{253}$

According to Ruth, the picnic finally gave up the barbecue for a return to fried chicken, partly because nothing attracted freeloaders like pit-cooked barbecue. Big groups of men had stayed up with the barbecue all the night before, "lying and burning up meat," as one Alum Creek old-timer described it. ${ }^{254}$ During her childhood, Irene Fleming's grandfather had charge of the barbecuing, the male-bonding ritual of the night before the picnic. Men hung around all night long — some of them-talking, joking, drinking coffee boiled in a big black pot, and perhaps quaffing stronger beverages. ${ }^{255}$ Some of these people must have seen the return to fried chicken as a social tragedy.

A few miles away and at almost the same time, African American residents of the north Bastrop sandylands staged major Juneteenth celebrations at the Piney and Sayers communities. As O L Flowers and Mary Lou Reese made clear in their recollections of the 
event, "Nineteenth of June" at Sayers resembled nothing so much as the Oak Hill Cemetery Association Picnic. Like the Oak Hill event it featured baseball, barbecue, ice cream, and a monumental picnic feast. Wilder, more secular Juneteenths certainly went on elsewhere, as perhaps in Bastrop and Elgin, but the Piney and Sayers celebrations were church-related. The Reese family always took two ice cream freezers (with different flavors) to Nineteenth of June at the Sweet Home Baptist Church at Sayers, and Mary Lou mostly recalled long, laborious turning of the cranks to make cold, delicious ice cream. Close to the church, sponsored by the church, it was a safe and sane Juneteenth for sure. Food was the feature attraction. "We had really good dinners," she said, That was a big time with us - to go to the Nineteenth of June, wow!"256

O L Flowers remembered the somewhat wilder men's side of this Sayers event. Juneteenth began the night before for the men and boys, with an all-night barbecue of whole sides of beef over a wire-covered pit, the cooks turning the beef from time to time with pitchforks. "Stay up all night cooking that meat," O L recalled. "We'd go down there at night and play around down there and sample off that meat. If we'd think a piece was about half done, we'd get a knife and cut a piece off." The next day "boys would meet together there and play ball, first one thing and another, just kind of a picnic thing, eating at a big old long table, women would cook different stuff and bring it." Not meat, however; meat was barbecue from the pit. Just before noon, the Sayers Juneteenth featured one event the whites at Oak Hill probably could not have staged, a parade of decorated ox wagons. The old ways persisted longer in rural black communities, including the use of oxen as work stock. "Some of them back in them days, they were still working oxen, and have oxen to wagons and a bunch of wagons meet up the road about a couple a miles, and then they'd come on down. Have the wagons decorated like they do cars nowadays." 257

Local people celebrated the Oak Hill cemetery picnic and Piney and Sayers Juneteenths as usual in early summer of 1941, but the days of these communities were numbered, especially that of Oak Hill, whose hinterland took up most of the 87 square miles of sandyland countryside. Life in the countryside was about to end for Oak Hill residents, though most of them were not ready to have it ended. War clouds darkened the horizon of the United States in the early months of 1941, and troubling news from abroad encroached on the weekly pages of the Bastrop Advertiser and Elgin Courier. However, few people on the north Bastrop sandylands imagined that such things might directly affect their lives, or could abolish in a few short weeks the world inherited across the generations from their parents and grandparents and great-grandparents. But they were very wrong. 


\section{Endnotes}

\begin{tabular}{|c|c|}
\hline 1. & Pannell 2004 \\
\hline 2. & Watson 2004 \\
\hline 3. & Ibid. \\
\hline 4. & L. Goerlitz 2004 \\
\hline 5. & Ibid. \\
\hline 6. & Light 2001 \\
\hline 7. & Ibid. \\
\hline 8. & Ibid. \\
\hline 9. & Ibid. \\
\hline 10. & Fleming 2004 \\
\hline 11. & A. Scott 2004 \\
\hline 12. & Carman 2004; Light 2001 \\
\hline 13. & Watson 2004 \\
\hline 14. & Majors 2004 \\
\hline 15. & Robinson 1998 \\
\hline 16. & Skelton and Freeman 1979; A. Scott 2004 \\
\hline 17. & Wilson 2004 \\
\hline 18. & Kastner 2004 \\
\hline 19. & Benford 2004; Thomas 2004 \\
\hline 20. & Thomas 2004 \\
\hline 21. & Ibid. \\
\hline 22. & Fort 2004 \\
\hline 23. & Ibid. \\
\hline 24. & Ibid. \\
\hline 25. & Ibid. \\
\hline 26. & Smith 2004 \\
\hline 27. & Wilson 2004 \\
\hline 28. & Light 2001 \\
\hline 29. & Flowers 2004 \\
\hline 30. & Light 2001 \\
\hline 31. & Kastner 2004 \\
\hline 32. & S. Scott 2004 \\
\hline 33. & Majors 2004 \\
\hline 34. & Kastner 2004 \\
\hline 35. & A. Scott 2004 \\
\hline 36. & Flowers 2004 \\
\hline 37. & L. Goerlitz 2004 \\
\hline 38. & Benford 2004 \\
\hline 39. & Ibid. \\
\hline 40. & Ibid. \\
\hline 41. & Pannell 2004 \\
\hline 42. & Ibid. \\
\hline 43. & Ibid. \\
\hline 44. & Ibid. \\
\hline 45. & Sharpless 1999 \\
\hline 46. & Light 2001 \\
\hline 47. & Morriss 2004 \\
\hline 48. & Ibid. \\
\hline 49. & Ibid. \\
\hline 50. & Pannell 2004 \\
\hline 51. & Barton 2004 \\
\hline 52. & Light 2001 \\
\hline 53. & Ibid. \\
\hline
\end{tabular}

54. S. Scott 2004

55. Barton 2004

56. Polly Owen, "Oak Hill," Bastrop Advertiser, December 25, 1941.

57. Flowers 2004

58. Barton 2004

59. Kastner 2004

60. Morriss 2004

61. Flowers 2004

62. Ibid.

63. A. Scott 2004

64. Hilliard 1972:173-177

65. A. Scott 2004

66. Pannell 2004

67. A. Scott 2004

68. Wilson 2004

69. Flowers 2004

70. Sitton and Utley 1997:60

71. Flowers 2004

72. E. Goerlitz 2004

73. Light 2001

74. Benford 2004

75. Sitton and Utley 1999:109

76. A. Scott 2004

77. Light 2001

78. Watson 2004

79. Barton 2004; Thomas 2004; Trepagnier 1983

80. Pannell 2004

81. Light 2001

82. Trepagnier 1983

83. Carman 2004; Light 2001

84. Fleming 2004

85. Sitton 1995:194

86. Fort 2004

87. E. Goerlitz 2004

88. Majors 2004

89. Polly Owen, "Oak Hill," Bastrop Advertiser, February 1, 1934

90. Fort 2004

91. Sitton and Utley 1999:247-255

92. E. Goerlitz 2004

93. Watson 2004

94. Carman 2004

95. S. Scott 2004

96. Majors 2004

97. Benford 2004

98. Flowers 2004

99. Morriss 2004

100. Flowers 2004

101. Light 2001

102. Majors 2004

103. Kastner 2004

104. Sitton and Utley 1999:102-104

105. Flowers 2004 
106. Ibid.

107. Ibid.

108. Ibid.

109. Ibid.

110. Light 2001

111. Ibid.

112. A. Scott 2004

113. E. Goerlitz 2004

114. L. Goerlitz 2004

115. Trepagnier 1983

116. Benford 2004

117. Frazee 1991; Nickels 2005

118. L. Goerlitz 2004

119. Pannell 2004

120. Benford 2004

121. Light 2001

122. Carman 2004; Light 2001

123. Light 2001

124. Johnson 2004

125. Thomas 2004

126. Watson 2004

127. Morriss 2004

128. Wilson 2004

129. Ibid.

130. Fleming 2004

131. Watson 2004

132. S. Scott 2004

133. Benford 2004

134. Flowers 2004

135. Ibid.

136. Ibid.

137. Ibid.

138. Kastner 2004

139. Smith 2004

140. Carman 2004

141. Light 2001

142. Benford 2004

143. Ibid.

144. Smith 2004

145. Light 2001

146. Benford 2004

147. Sitton and Utley 1997:41

148. Flowers 2004

149. Ibid.

150. Fort 2004

151. Light 2001

152. Carman 2004

153. A. Scott 2004

154. Pannell 2004; Smith 2004

155. A. Scott 2004

156. Fort 2004

157. A. Scott 2004

158. Light 2001

159. Bastrop County Historical Commission 1991
160. Morriss 2004; Pannell 2004; Watson 2004; Wilson 2004

161. Pannell 2004

162. Morriss 2004

163. Pannell 2004

164. Polly Owen, "Oak Hill," Bastrop Advertiser, January 3, 1925.

165. Polly Owen, "Oak Hill," Bastrop Advertiser, February 5, 1925

166. Ibid., February 26, 1925

167. Ibid., April 2, 1925

168. Ibid., April 23, 1925

169. Ibid., April 30, 1925

170. Ibid., May 21, 1925

171. Ibid., June 4, 1925

172. Ibid., June 11, 1925

173. Ibid., June 25, 1925

174. Ibid., July 8,1925

175. Ibid., July 23, 1925

176. Ibid., August 27, 1925

177. Ibid., September 3, 1925

178. Ibid., September 10, 1925

179. Ibid., September 24, 1925

180. Ibid., October 1, 1925

181. Ibid., October 29, 1925

182. Ibid., November 12, 1925

183. Ibid., December 10, 1925

184. Sitton and Utley 1999:61

185. Polly Owen, "Oak Hill," Bastrop Advertiser, November 12, 1925

186. Ibid., November 8, 1934

187. Texas State Board of Education 1937, 206207

188. A. Scott 2004

189. Watson 2004

190. Pannell 2004

191. Ibid.

192. Morriss 2004

193. L. Goerlitz 2004

194. Carman 2004; Light 2001

195. Morriss 2004

196. Carman 2004; A. Scott 2004

197. A. Scott 2004

198. Johnson 2004

199. Flowers 2004

200. Watson 2004

201. Flowers 2004

202. Pannell 2004

203. Watson 2004

204. Fleming 2004

205. Pannell 2004

206. Watson 2004

207. Barton 2004

208. Wilson 2004 
209. Smith and Pannell 1984

210. Trepagnier 1983

211. Thomas 2004

212. Sitton and Utley 1999:245

213. Morriss 2004

214. Light 2001

215. Ibid.

216. Ibid.

217. Ibid.

218. Ibid.

219. Ibid.

220. Smith 2004

221. Benford 2004

222. Carman 2004

223. S. Scott 2004

224. Light 2001

225. Pannell 2004

226. Light 2001

227. Pannell 2004

228. Benford 2004

229. Flowers 2004

230. Flowers 2004

231. Johnson 2004

232. Light 2001

233. A. Scott 2004
234. Carman 2004; Light 2001

235. A. Scott 2004

236. Davis 1986

237. Flowers 2004

238. Sitton 1995:194

239. Flowers 2004

240. Ibid.

241. Ibid.

242. Pannell 2004

243. Polly Owen, "Oak Hill," Bastrop Advertiser, October 14, 1934

244. Majors 2004

245. Morriss 2004

246. A. Scott 2004

247. Fleming 2004

248. Pannell 1985

249. Fort 2004

250. Watson 2004

251. Smith 2004

252. Ibid.

253. Light 2001

254. Sitton 2005:194

255. Fleming 2004

256. Benford 2004

257. Flowers 2004 


\section{Chapter 4}

\section{The Army Comes to Bastrop County}

Germany's blitzkrieg (lightening war) defeat of Poland in 1939 served as a wake-up call for the United States Army. The Army quickly understood that it needed to train troops to stop Hitler's panzers. Old concepts of static defense had been rendered obsolete. The new training required additional military camps with room for full-size infantry and armored divisions to maneuver. Several of the camps planned nationally were envisioned for Texas, which had varied terrain, mild winters, and areas of lightly-populated countryside that were well served by railroads and highways. Texas also had powerful and diligent politicians in Washington who thought new military camps would be good for the state, among them 10th District Representative Lyndon Baines Johnson (LBJ).

The search to select sites for the new military training camps in Texas went on somewhat behind the scenes, but politicians and local chambers of commerce knew of it and sought to influence the Army to locate near them. Supporters saw a new military camp as the perfect way to end their local Great Depression in one fell swoop, whatever its social effects upon their communities. A powerful coalition of U.S. Congressman LBJ, State Senator Pat Page of Bastrop, and the chambers of commerce of Austin and Bastrop, among others, soon convinced the Army to choose the north Bastrop sandylands for one of its new camps.
The War Department officially approved Camp Swift in January 1941, but made no public announcement of this. ${ }^{1}$ Planning for the camp began soon afterward and moved quickly. By December 7, the day the Japanese attacked Pearl Harbor, Army engineers had drawn up detailed land-use plans for the camp, a team of architects had finished drawings for most of the camp's 2,750 buildings, and government attorneys were ready to start the legal process for taking possession of 425 tracts of privately owned land that totaled 52,162 acres. When LBJ officially announced on December 18, 1941, eleven days after Pearl Harbor, that the War Department planned a military camp in Bastrop County, he said "construction can begin overnight," ${ }^{2}$ which was virtually true.

Things did move very fast. The government took most private land by purchase or condemnation proceedings between March and May of 1942. Meanwhile, it built Camp Swift. Less than one month after Pearl Harbor, the Lower Colorado River Authority (LCRA) turned on electric power at the Camp Swift construction site. Soon thereafter, working night and day, approximately 18,000 workers labored to build the camp in a massive construction project that would take only 108 working days. ${ }^{3}$

The first six months of 1942 turned Bastrop County upside down. The county's population 
of around 22,000 doubled in three months. Pressure on schools and the local sewer systems caused huge problems. Roads were crowded with vehicles day and night. Misdemeanor crimes (drinking, gambling, fighting, petty theft) increased eight-fold. For miles in every direction, locals rented out spare bedrooms and out-buildings, while downtown merchants turned empty rooms above stores into dormitories. Farmers opened tent camps in their pastures, and one man converted his cement-floored hog shed into rental quarters. Trailer camps sprang up everywhere. Still, this was not enough, and every night local roadsides were lined with tents, cars, and trailers full of people with no place to sleep. Many new businesses quickly got under way in Bastrop and Elgin - cafes, honky tonks, pool halls, liquor stores, movie theaters, and others. The Elgin Courier of March 12, 1942, noted:

Elgin has ten cafes busy feeding through the morning and evening and preparing lunches to go. Elgin is humming with activity seven days a week and there are so many cars parked at the curb now uptown that the natives have to refer to the calendar to tell when it is Saturday. Saturday being the 'big day' of the average small town, the day set apart for country people to come in to do their shopping.

No wonder, then, that the "country people" were nonplussed. The world they knew had transformed itself almost overnight, and without warning. None of the persons interviewed for the oral history project recalled that their families had heard about Camp Swift before December 1941, although political lobbying for the camp, then the Army's advance planning, had gone on for almost two years. The countryside remained remote from the town in 1940, local newspaper editors had been discreet, and perhaps some of our interviewees' parents who had heard rumors about a military camp chose not to pass them on. As in the case of Camp Hood (now Fort Hood) in Coryell County, probably many rural people who heard early talk about a military camp found it hard to believe. ${ }^{4}$

After LBJ's announcement of Camp Swift on December 18, 1941, the War Department moved quickly to take the land, and the farm families of north Bastrop County had little time to adjust to circumstances. Construction for the camp began in March 1942 before all the property had been acquired, and the Army began training in May. As Charles Bell bluntly summed up acquisition procedures to Camp Swift researcher David G. Robinson, "they paid you and gave you so many days to get off."

The LCRA served as the Army's purchasing agent for Camp Swift, and the Army and the LCRA were in a hurry. Robinson wrote:

The official story has it that the War Department's treatment of the residents and the rural society of the region was correct, if somewhat curt. Yet the effects of the imposition of Camp Swift on the region, disruptive and embittering at the time, can still be felt and observed more than 50 years later. The LCRA proceeded quickly, buying properties at low prices in an exercise that was ill-disguised condemnation. $^{5}$

The LCRA indeed paid low prices, usually ranging from $\$ 6$ to $\$ 20$ an acre, and after residents sold out they had only 30 days to vacate the property. The Army wanted only the land and so did not compensate families for buildings and improvements: houses, out-buildings, fences, and pecan and peach orchards. Residents could keep these - if they could remove them in 30 days, which of course most of them could not. Some families even failed to locate and remove 


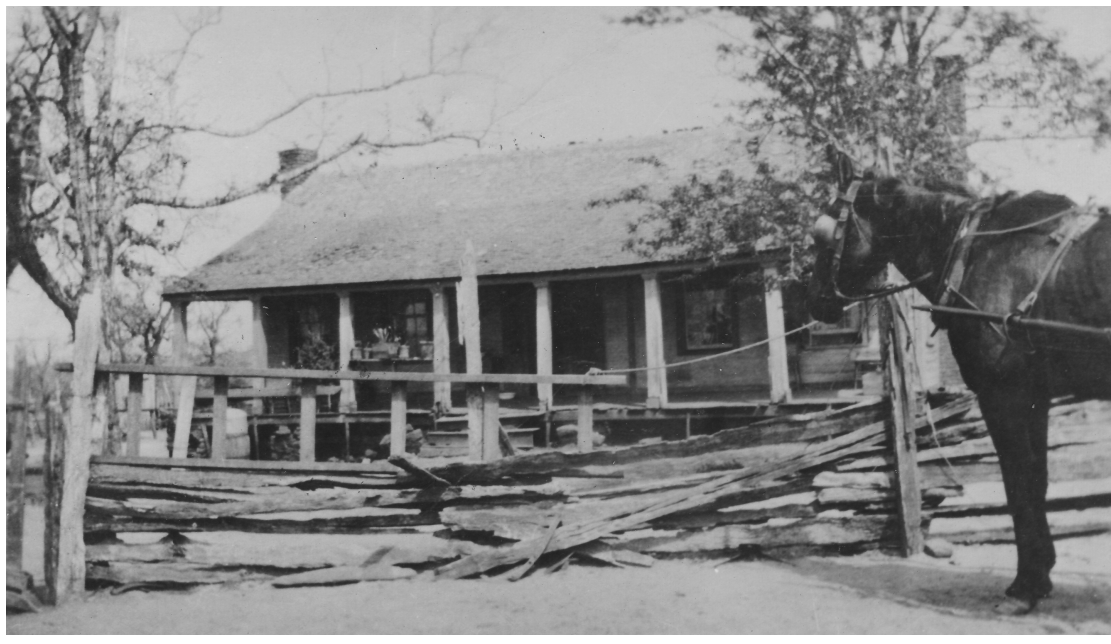

Figure 4-1. Ransom House, date unknown (Fay Owen Pannell).

all of their stock. Charles Bell recalled desperate days spent helping his grandfather demolish the buildings on his property, removing them as recycled lumber in many trips with a 1929 Model A truck. Many of the 350 or so families displaced by the camp could not remove their buildings and so abandoned them to the Army, which later knocked them down as hazards or used them as artillery or bombing targets.

The historic Ransom house in Oak Hill, constructed of cedar logs in 1853 , became one such target (Figure 4-1). ${ }^{6}$

As Robinson also noted (and our interviews amply confirmed), the camp building boom with its influx of 18,000 workers coincided with farm families' displacement from their properties, so some displaced families could not find anywhere nearby to stay. The Otis family had to live under a tree, lacking any other shelter. Communities like Oak Hill dispersed quickly, with many friends and neighbors losing touch with each other. People who stayed in the area suffered from the new overcrowding, though some might have profited from the new jobs (Figure 4-2). Businessmen of Bastrop, Smithville, and Elgin, many of whom had backed the lobbying effort to get the camp, certainly profited from the crowds and the freeflowing government money. ${ }^{7}$

From the perspective of sixty years later, some persons we interviewed about the land taking were almost as terse as Charles Bell. Fay Owen Pannell's parents "didn't have any choice" about selling out. "We didn't know they were

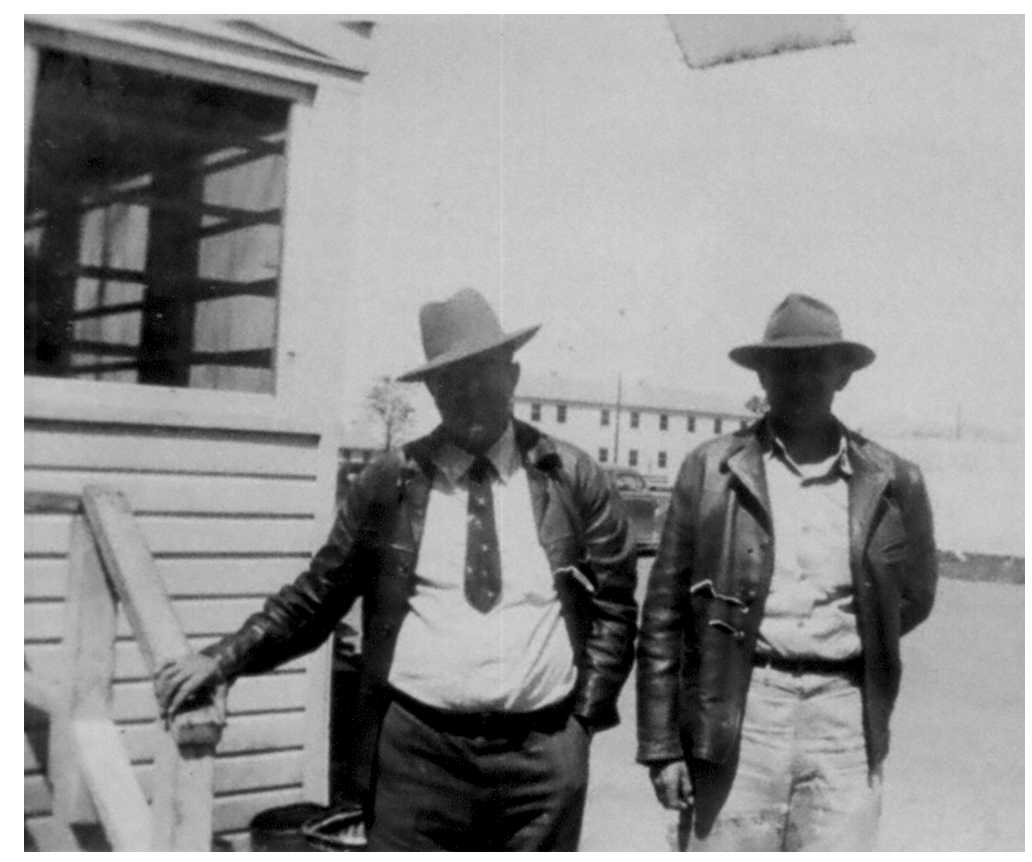

Figure 4-2. Harvey Smith and Harry Kunkle working at Camp Swift during the early 1940s (Louise Smith Goerlitz). 
even considering it out here - wouldn't have thought about a camp out here in this old poor country." Asked to say more, Fay echoed the generalizations of David Robinson: in her opinion, the Owen family had been paid low value, given little time to get off, forced to abandon their buildings and improvements, and could find no comparable place to go to with the money the government paid them (Figure 4-3). ${ }^{9}$

Abner Scott said much the same thing. When Grover Scott told the authorities he would like to leave his historic Scott family log house in place, hoping to buy it back after the war, someone told him, "If you want any of that house, you better take it with you because they'll roll tanks right through that thing." ${ }^{10}$ Grover set his sons Abner and Dan to a month's labor tearing the house down and salvaging the lumber, though they had to abandon the Civil War-era cedar logs of the oldest part of the house. ${ }^{11}$

Looking back, some people did not recall their parents ever questioning the actions of the United States government in wartime, when so many were being asked to risk their lives in combat. Evelyn Cottle Wilson's parents willingly gave up their new farm, acquired in 1939, and made no complaint that Evelyn ever heard. ${ }^{12}$ Nor did Irene Fleming Watson's parents, although the Flemings “weren't happy about it, because they'd been on that land a long time - it upset 'em."13 The Flemings suffered in public silence, however, "because people were patriotic in those days, and they thought it was not very patriotic to fight your government."14 Every child in the Fleming family except one went into the service. ${ }^{15}$ Some patriots went even further. A man wrote to the Elgin Courier in

1942 that "parting with the old homestead is certainly like tearing out my own heart, but if my country needs it I will willingly give it up." 16

In truth, fighting one's government over the land taking was futile in general and even more so for African Americans. Ruby Mae Thomas Johnson recalled:

We didn't have enough time. A man came and he just told us we had to get out. Back in them days, I'm gonna be honest with you, back in them days the white man's word was what was. But everybody moved out, too. I don't know if they had more say-so, the whites, than we did around there. All I know, my daddy and my mama said we got to go. We left the old house there, we just moved out. It was sad. ${ }^{17}$

The price paid for the Thomas family land, which had been passed down from freedman Jackson Morgan, still rankled Ruby Mae's brother Walter in 2004. It seemed almost unbelievable. The white LCRA man had offered the very minimum land price to the poor black 
family. "Three hundred and some-odd dollars for 83 acres! Lord have mercy, Jesus!"18

The people that refused to sell out and move off quickly had their property condemned and were evicted. Dean Fort told of his great-uncle Doll Fort, "They forcefully moved him out, cause he wouldn't move, he didn't think the government had any business taking his land away from him."19 Dean generalized about the varied reactions of his family to the land taking in words that would have served for many other such families:

We had two or three Fort families lived around Oak Hill Cemetery, they were all disgusted, because they didn't want to get rid of their land, even though the old land, some of it, was so bad they couldn't hardly make a living on it no more. But that was their home, they wanted to keep it. Now, some of 'em were happy, they were glad to get rid of it, they were glad to do it for their country. But some of the old people they said, no, this is home. Like old Uncle Doll, if they'd never made him move out he would probably been buried on the land. But he sat there all week long by himself out in them sand hills. $^{20}$

Some people liked the sand hills. Oak Hill newspaper columnist Polly Owen tolled the death knell for Oak Hill throughout the first six months of 1942, writing her last report to the Bastrop Advertiser with MP's almost at her front gate.

The first Bastrop Advertiser edition run after Pearl Harbor, published on December 11, 1941, printed a big "V" for victory, one foot high, under the headline "Japan's Attack on U.S. Naval Bases Arousing Nation to Fighting Pitch." Thereafter, week after week, the paper continued in this same patriotic vein, with photos of every Bastrop County boy who signed up and a "Remember Pearl Harbor" column on the front page. Clearly, with Bastrop County sons leaving for boot camp and foreign war, this was not a good time to protest the hardships of local land takings.

Polly's next column came on December 25, 1941, a few days after LBJ announced the coming of Camp Swift to Bastrop County. Polly did not directly address this, but wrote that "We are feeling depressed and sad of the existing conditions of the day." ${ }^{21}$ Oak Hill School held its big Christmas program on this day, following a 35-year tradition, but by that time Polly knew it would be the last.

In her column on January 16, 1942, Polly recorded that she heard "big tractors roaring," as work began on Camp Swift roads near Oak Hill. "We still can't realize just how its going to be when we receive notice to move, but we'll do it with chins up, for it [sic] the boys sacrifice their lives, we can do our bit, for we brought nothing into this world and can take nothing away."22

By early February, Polly had more inklings about "just how it's going to be," and she found it almost too painful to bear:

Powerful machinery is dipping into the red clay hill just in front of the Lee Scarborough place and hauling the dirt to the new road being built. The crew of workmen worked hard all day yesterday, Sunday, or the Lord's Day. It seems hard that it seems necessary to work on that day, and not to assemble for worship. Have we as a nation forgotten God? ${ }^{23}$

Grandfather DeGlandon had just died. For many years he served as official barbecue pit man at the Oak Hill Cemetery Association Picnic. She wondered if he would have a successor. ${ }^{24}$ 


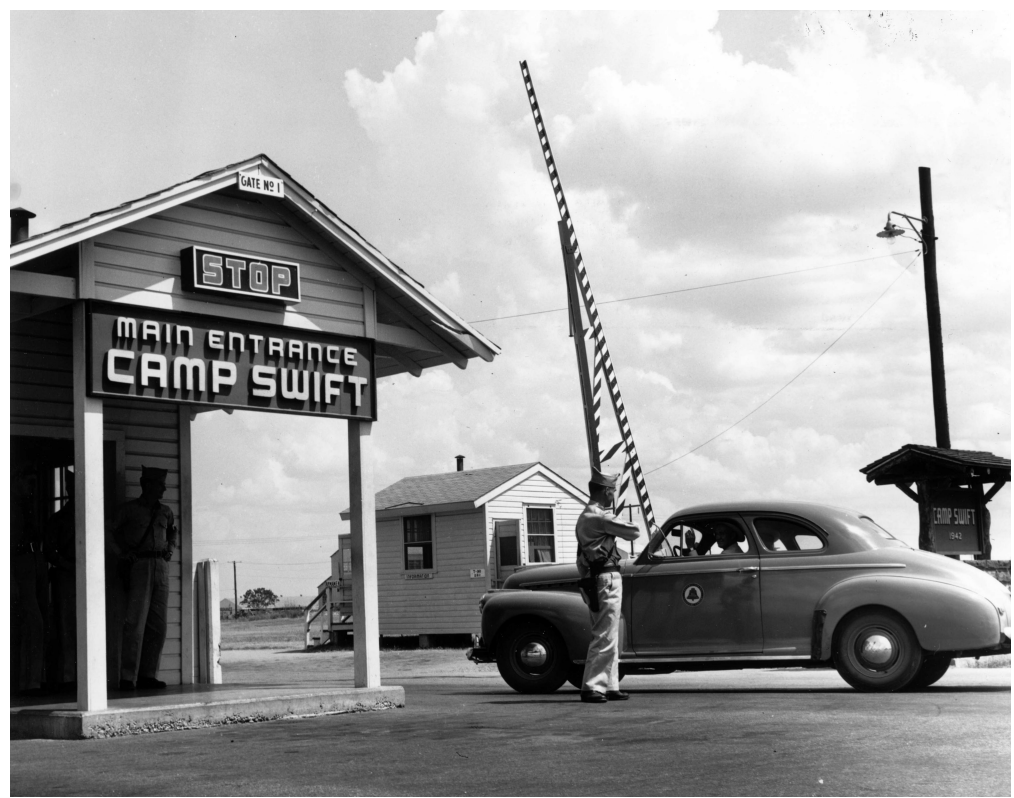

Figure 4-4. Entrance to Camp Swift, 1944 (Denver Public Library, Western History Collection, TMD-393).

She had just read in the Austin Tribune that Camp Swift is under construction on "4,162 acres of sandy, barren farm land" in Bastrop County, and this slighting reference to her home countryside made her furious:

That just don't suit some of us for it to be called that, for when you can raise twenty-nine varieties of vegetables on one acre, it don't seem as if it is so poor. We have a great government and wonderful president, but the party who wrote the article, just don't know what a little old sandy land home is worth. ${ }^{25}$

In her column of February 26, Polly wrote that Oak Hill people now were being stopped and turned back by Army patrols when they tried to travel certain roads they had traveled all their lives. "All through the night we hear the hoof beat of the horses ridden by the patrolmen. The roaring of the machinery, cars traveling all night long, gives us a feeling of uneasiness. No one here is living a normal life any more. Everything seems so different."26
On March 6, she observed that even outside the boundaries of the camp, farmers delayed planting due to a general "spirit of unrest." The towns filled with unfamiliar faces, traffic, new liquor stores, "turmoil and hurry - all this to me is heartbreaking.."27

On April 4, she informed readers of her column that peaches and pears now loaded her fruit trees, planted as a county agent demonstration orchard two decades before. She hoped she and Edgar would be able to stay on their place long enough to gather fruit for a last harvest. ${ }^{28}$ Then, for the first time, Polly faltered; no more April columns followed this one - at least not in the Bastrop paper.

By the column of May 14, the end had fast approached. All her neighbors were moving out, and the community of Oak Hill was disassembling in every direction. ${ }^{29}$ A week later, on May 21, Polly noted that "Every week brings us near the final moving day (June 15)." She felt "pangs of sadness even though we are willing to make the sacrifice which is small compared to the lives which are being given to perpetuate our freedom. If just gives a feeling we can't describe. Land that is being offered for sale is much higher than the price being paid those who have to move." ${ }^{30}$ Many families now made their last visits to old home places and the Oak Hill Cemetery. All roads would be closed on June 15 (Figure 4-4). ${ }^{31}$ 


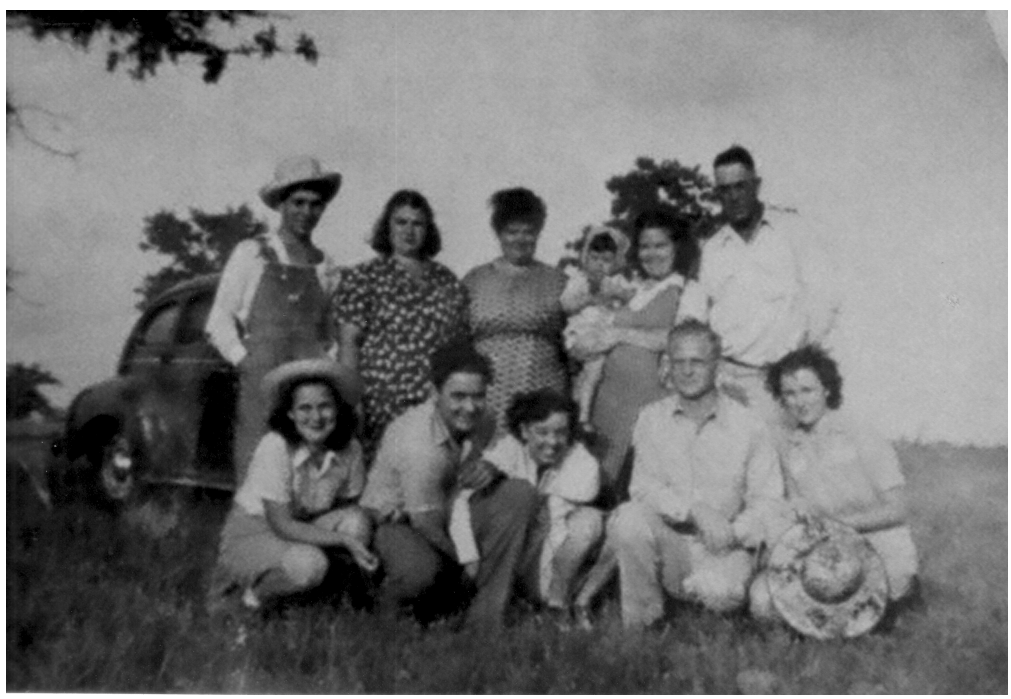

Figure 4-5. Harvey Smith family visits their old homeplace on Camp Swift, 1945 (Louise Smith Goerlitz).

By May 28, Oak Hill Church and Oak Hill School had been torn down - a community effort in each case, just like those that erected them. Bulldozers were destroying neighboring barns, fencerows, and fences, and the familiar landmarks of the countryside disappeared. Polly wrote regretfully of the church, "Perhaps if we had been more persistent in holding religious services there, and not neglected our duty, some way may have been provided to let it stand, but now it's just a memory." 32 The last Oak Hill families departed - everyone but Edgar and Polly Owen.

By Polly Owen's last column on July 18, 1942, the north Bastrop sandylands belonged to the Army. Owen wrote of it on the evening of June 15 , the day she and Edgar relocated to a small farm north of McDade. "We will miss the grand old oak trees at our place," Polly wrote, "also had many shrubs and plants, fruit trees and things, but now we'll have to start all over again to build another home." Oak Hill was no more, "for tonight that community passes into history." 33

The ties that bind were hard to break. After the war, families returned to their old homeplaces to remember their lives. These trips took the form of family reunions (Figure 4-5) and fishing trips (Figure 4-6). Even many years after losing the land the memories were still strong. Many of the interviewees cried while remembering

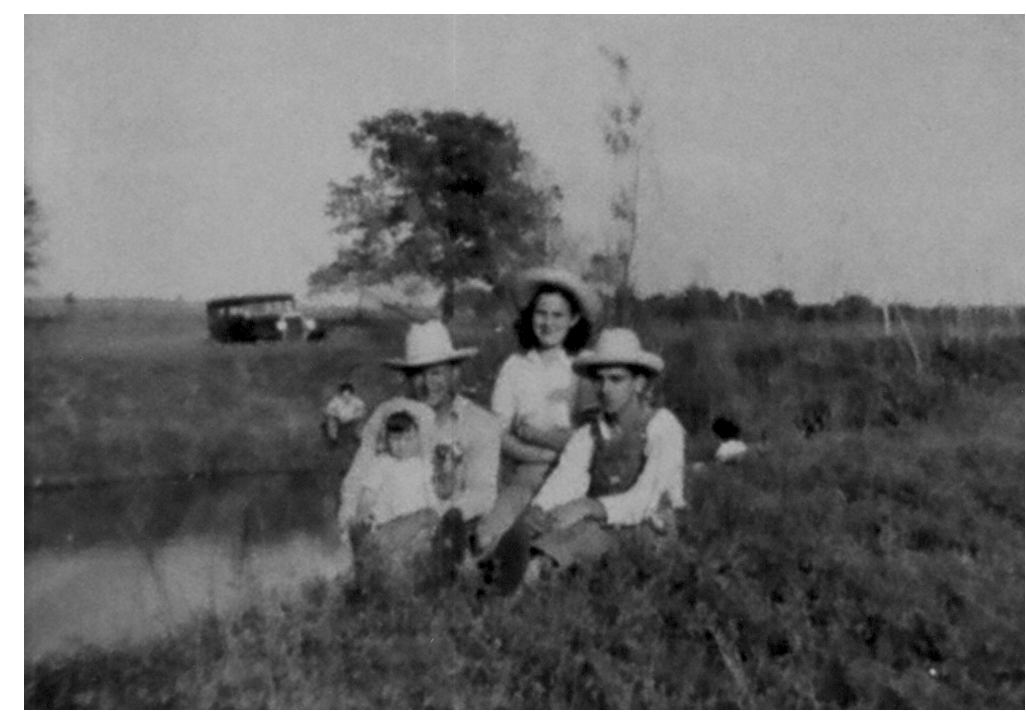

Figure 4-6. Smith family fishing at the old homeplace around 1946 (Louise Smith Goerlitz). 


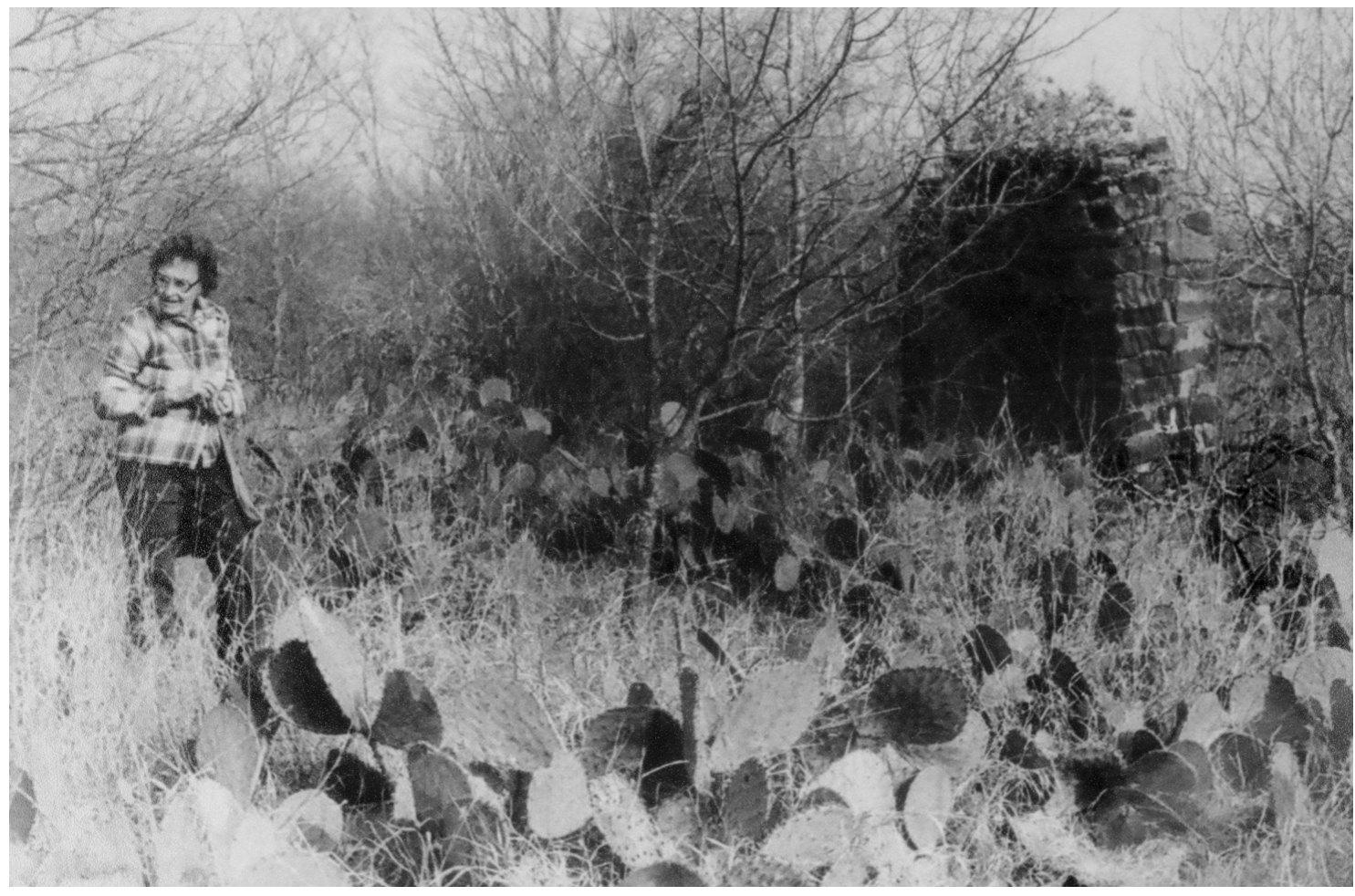

Figure 4-7. Fay Owen Pannell visiting the ruins of a house site on Dogwood Creek near Oak Hill Road on Camp Swift, 1970s (Fay Owen Pannell).

life before the war, and grieved their families' losses. Their homes are gone, destroyed by training exercises, and the land altered beyond recognition, overgrown with prickly pear and brush (Figure 4-7). 


\section{Endnotes}

1. Wharton 2000:173

2. Wharton 2000:174

3. Leffler 2001

4. Sitton 2003:269

5. Robinson 1998; Robinson et al. 2001

6. Robinson 1998

7. Ibid

8. Pannell 2004

9. Ibid.

10. A. Scott 2004

11. Ibid

12. Wilson 2004

13. Watson 2004

14. Ibid.

15. Ibid

16. Wharton 2000:185

17. Johnson 2004
18. Thomas 2004

19. Fort 2004

20. Ibid.

21. Polly Owen, "Oak Hill," Bastrop Advertiser, December 25, 1941.

22. Ibid., January 16, 1942

23. Ibid., February 5, 1942

24. Ibid.

25. Ibid.

26. Ibid., February 26, 1942

27. Ibid., March 6, 1942

28. Ibid., April 4, 1942

29. Ibid., May 14, 1942

30. Ibid., May 21, 1942

31. Ibid.

32. Ibid., May 28, 1942

33. Ibid., July 18, 1942 


\section{BibliograPHY}

Barkley, Mary Starr

1970 A History of Central Texas. Austin Printing Company, Austin.

Barton, Gertrude (Dunkin)

2004 Taped interview with Martha Doty Freeman, May 31, 2004. Camp Swift Oral History Project, Center for American History, The University of Texas, Austin.

Bastrop County Historical Commission

1983 “Early Bastrop County Fort.” Texas Historical Commission Marker File, Bastrop County. Austin, Texas.

1991 "The CCC at Bastrop State Park." Texas Historical Commission Marker File, Bastrop County. Austin, Texas.

1995 “Camp Swift.” Texas Historical Commission Marker File, Bastrop County. Austin, Texas.

Benford, Mary Lou Reese

2004 Taped interview with Thad Sitton, April 21, 2004. Camp Swift Oral History Project, Center for American History, The University of Texas, Austin.

Blackwell, Bettye Lynn

See Light, Bettye Lynn (Blackwell)

Blackwell, Leola

See Carman, Leola (Blackwell)

Buder, John J.

1996 Sayersville, Texas. In The New Handbook of Texas, Vol. 5, p. 907. Texas State Historical Association, Austin.

Campbell, T. N.

1985 Jean Louis Berlandier, French Naturalist: His Three Days in Bastrop County, 1828. Sayersville Historical Association Bulletin 6:8-10.

1986 Name All the Indians of the Bastrop Area. Sayersville Historical Association Bulletin 7:7-10.

Carman, Leola (Blackwell)

2004 Taped interview with Martha Doty Freeman, June 2, 2004. Camp Swift Oral History Project, Center for American History, The University of Texas, Austin.

Cottle, Evelyn

See Wilson, Evelyn (Cottle) 
Davis, E. Mott

1986 The Sayersville Elm. Sayersville Historical Association Bulletin 7:14-16.

Deetz, James

1977 In Small Things Forgotten: The Archaeology of Early American Life. Doubleday, New York.

Doughty, Robin W.

1983 Wildlife and Man in Texas: Environmental Change and Conservation. Texas A\&M University Press, College Station.

Dunkin, Gertrude

See Barton, Gertrude (Dunkin)

Fleming, Irene

See Watson, Irene (Fleming)

Fleming, Jonathan Curtis

2004 Taped interview with David Nickels, July 20, 2004. Camp Swift Oral History Project, Center for American History, The University of Texas, Austin.

Flowers, O L

2004 Taped interview with Thad Sitton, April 6, 2004. Camp Swift Oral History Project, Center for American History, The University of Texas, Austin.

Fort, Dean

2004 Taped interview with Thad Sitton, April 13, 2004. Camp Swift Oral History Project, Center for American History, The University of Texas, Austin.

Frary, Michael and William A. Owens

1973 Impressions of the Big Thicket. University of Texas Press, Austin.

Frazee, Jerry D.

1991 The Legacy of Antoine Aussiloux. Sayersville Historical Association Bulletin 9:11-13.

Goerlitz, Louise (Smith), and Erhard Oscar Goerlitz

2004 Taped interview with Dave Nickels, May 27, 2004. Camp Swift Oral History Project, Center for American History, The University of Texas, Austin.

Gonzalez, Anibal A., and Davis McAuley

1982 Notes on Sayers or Sayersville. Sayersville Historical Association Bulletin 1: unpaginated.

Hancock, JoNell

See Majors, JoNell (Hancock) 
Hilliard, Sam Bowers

1972 Hog Meat and Hoecake: Food Supply in the Old South, 1840-1860. Southern Illinois University Press, Carbondale.

James, Delia Paxton

1953 David Brown Moves to Texas. Gonzales Inquirer, 4 June, Gonzales, Texas.

Jenkins, John H.

1958 Recollections of Early Texas. University of Texas Press, Austin.

Johnson, Ruby Mae (Thomas)

2004 Taped interview with David Nickels, August 10, 2004. Camp Swift Oral History Project, Center for American History, The University of Texas, Austin.

Jordan, Terry G.

1978 Texas Log Buildings: A Folk Architecture. University of Texas Press, Austin.

Jordan, Terry G. and Matti Kaups

1989 The American Backwoods Frontier: An Ethnic and Ecological Interpretation. John Hopkins University Press, Baltimore.

Joyner, Charles

1984 Down By the Riverside: A South Carolina Slave Community. University of Illinois Press, Urbana.

Kastner, Morris J.

2004 Taped interview with David Nickels, April 29, 2004. Camp Swift Oral History Project, Center for American History, The University of Texas, Austin.

Kesselus, Kenneth

1986 History of Bastrop County, Texas, Before Statehood. Jenkins Publishing Company, Austin.

1987 History of Bastrop County, Texas, 1846-1865. Jenkins Publishing Company, Austin.

Kirby, Jack Temple

1990 Rural Worlds Lost: The American South, 1920-1960. Louisiana University Press, Baton Rouge.

Leffler, John J.

2001 The History of the Camp Swift Area, 1830-1950. In An Archaeological Inventory of Camp Swift, Bastrop County Texas, by David G. Robinson, Timothy M. Meade, Leeann Haslouer Kay, Linn Gassaway, and Dustin Kay, pp. 14-30. Archaeological Survey Report No. 316. Center for Archaeological Research, The University of Texas at San Antonio. 
Light, Bettye Lynn (Blackwell)

2001 "My Memories." Unpublished manuscript on file, Camp Swift Oral History Project, Center for American History, The University of Texas, Austin.

Lim, Brandy G, Frederick B. Pearl, and Sue. W. Moss

2000 Cultural Resources Survey of US 290 SH 95 to One Mile East of FM 696, Bastrop County, Texas. Report of Investigations No. 1. Quadrant Consultants. Prepared for Texas Department of Transportation, Austin District.

Majors, JoNell (Hancock)

2004 Taped interview with Martha Doty Freeman, June 2, 2004. Camp Swift Oral History Project, Center for American History, The University of Texas, Austin.

Marks, Paula Mitchell

1996a Bastrop County. In The New Handbook of Texas, Vol. 1, pp. 412-413. Texas State Historical Association, Austin.

1996b McDade, Texas. In The New Handbook of Texas, Vol. 4, pp. 389-390. Texas State Historical Association, Austin.

McAuley, Davis

1983 Some Notes on Calvin, Texas. Sayersville Historical Association Bulletin 3:11.

1986 Slave Life and Work in Bastrop County. Sayersville Historical Association Bulletin 7:17-25.

1988 Education and Religion Under Slavery. Sayersville Historical Association Bulletin 8:16-19.

1991 Slave Family Life in Bastrop County, Texas 1845-1865. Sayersville Historical Association Bulletin 9:14-21.

Moore, Bill

1977 Bastrop County, 1691-1900. Nortex Press, Wichita Falls.

Miller, May Belle

See Morriss, May Belle (Miller)

Morriss, May Belle (Miller)

2004 Taped interview with Martha Doty Freeman, June 1, 2004. Camp Swift Oral History Project, Center for American History, The University of Texas, Austin.

Nickels, David L., Melissa L. Lehman, and C. Britt Bousman

2003 Archaeological Evaluation of 39 Category V Sites at Camp Swift, Bastrop County, Texas: 2001. Archeological Studies Report No. 3. Center for Archaeological Studies, Southwest Texas State University, San Marcos. 
Nickels, David. L., Antonio. E. Padilla, James. E. Barrera, and C. Britt Bousman

2005 An Archaeological Survey of 307 Acres at Camp Swift, Bastrop County, Texas: 2003. Archaeological Studies Report No. 6. Center for Archaeological Studies, Texas State University-San Marcos.

Nightengale, Bruce A., and Henry B. Moncure

1996 Intensive Cultural Resource Survey and Monitoring at the LCRA Camp Swift Regional Wastewater Project, Bastrop County, Texas. Cultural Resources Report No. 3. Lower Colorado River Authority, Environmental Protection Division.

Owen, Fay

See Pannell, Fay (Owen)

Owen, Polly

1925-1942 "Oak Hill." Weekly column of community news in the Bastrop Advertiser.

Pannell, Fay (Owen)

1985a The Black Cemetery at Oak Hill. Sayersville Historical Association Bulletin 6:17-19.

1985b Oak Hill-A Southern Folk Cemetery. Sayersville Historical Association Bulletin 6:20-22.

2001 Confederate Veteran H.M. Mobley Buried at Oak Hill Cemetery. Sayersville Historical Association Bulletin 11:13.

2004 Taped interviews with Thad Sitton, March 31 and April 2, 2004. Camp Swift Oral History Project, Center for American History, The University of Texas, Austin.

Pannell, Fay, and Mattie Cailborne

1991 The Pain or Lyman Cemetery. Sayersville Historical Bulletin 9:2-6.

Reese, Mary Lou

See Benford, Mary Lou (Reese)

Robinson, David G.

1998 War Camp Creates Oak Hill Refugees. Sayersville Historical Association Bulletin 10:3-4, $6-7$.

2001 Revisiting the Old Sayers Mine. Sayersville Historical Association Bulletin 11:7-11.

Robinson, David G., Timothy M. Meade, Leeann Haslouer Kay, Linn Gassaway, and Dustin Kay 2001 An Archaeological Inventory of Camp Swift, Bastrop County, Texas. Archaeological Survey Report No. 316. Center for Archaeological Research, The University of Texas at San Antonio.

Sayersville Historical Association

1998 Ransom House Floor Plan (illustrator unknown). Sayersville Historical Association Bulletin $10: 8$ 
Schmidt, James C., and Maria E. Cruse

1995 Cultural Resources Survey Camp Swift, Bastrop County, Texas. Espey, Huston \& Associates, Inc. Austin, Texas.

Scott, Abner C.

2004 Taped interview with David Nickels, April 29, 2004. Camp Swift Oral History Project, Center for American History, The University of Texas, Austin.

Scott, S. J. "Jack"

2004 Taped interview with David Nickels, May 7, 2004. Camp Swift Oral History Project, Center for American History, The University of Texas, Austin.

Sharpless, Mary Rebecca

1999 Fertile Ground, Narrow Choices: Women on Texas Cotton Farms, 1900-1940. University of North Carolina Press, Chappel Hill.

Sitton, Thad

1995 Backwoodsmen: Stockmen and Hunters Along a Big Thicket River Valley. University of Oklahoma Press, Norman.

2003 Harder Than Hardscrabble: Oral Recollections of the Farming Life From the Edge of the Texas Hill Country. University of Texas Press, Austin.

Sitton, Thad and James H. Conrad

2005 Freedom Colonies: Independent Black Texans in the Time of Jim Crow. University of Texas Press, Austin.

Sitton, Thad, and Dan K. Utley

1997 From Can See To Can't: Texas Cotton Farmers On the Southern Prairies. University of Texas Press, Austin.

Skelton, Duford W., and Martha Doty Freeman

1979 A Cultural Resource Inventory and Assessment at Camp Swift, Texas. Texas Archeological Survey Research Report No. 72. The University of Texas, Austin.

Smith, Louise

See Goerlitz, Louise (Smith)

Smith, Ruth E.

1985 Alcide De Glandon. Sayersville Historical Association Bulletin 6:12-13.

2004 Taped interview with Martha Doty Freeman, April 16, 2004. Camp Swift Oral History Project, Center for American History, The University of Texas, Austin. 
Smith, Ruth, and Fay Pannell

1984 Oak Hill: a Vanished Community. Sayersville Historical Association Bulletin 5:6-12.

Smithwick, Noah

1983 [1900] The Evolution of a State: Recollections of Old Texas Days. Reprinted. University of Texas Press, Austin. Originally published 1900, Gammel, Austin.

Smyrl, Vivian Elizabeth

2001 "Wayside, Texas." The Handbook of Texas Online. <http://www.tsha.utexas.edu/handbook/ online/articles/view/WWW/hrwnx.htm>, accessed September 2004.

Texas Almanac and State Industrial Guide 1926:141-142. Belo \& Co., Dallas, Texas.

Texas Almanac and State Industrial Guide 1933:143. Belo \& Co., Dallas, Texas.

Texas State Board of Education

1937 A Report of the Results of the Texas Statewide School Adequacy Survey. Austin, Texas.

Thomas, Ruby Mae

See Johnson, Ruby Mae (Thomas)

Thomas, Walter B.

2004 Taped interview with Thad Sitton, April 15, 2004. Camp Swift Oral History Project, Center for American History, The University of Texas, Austin.

Tomka, Marybeth S. F., and Daniel J. Crouch

1996 Stone Projectile Points to World War II Tank Destroyers and Land Mines: Intensive Archeological Survey at Lake Bastrop State Park Bastrop County, Texas. Texas Parks and Wildlife Department, Public Lands Division, Cultural Resources Program, Austin, Texas.

Trepagnier, Peggy

1982 A Visit With Isom and Viola Reese. Sayersville Historical Association Bulletin 2:2-3.

1983 Sayers 1911-1916. Sayersville Historical Association Bulletin 3:9-10.

1984 A Visit With Annie Harden. Sayersville Historical Association Bulletin 4:7-9.

U.S. Bureau of the Census

1927 Unites States Census of Agriculture: 1925, Vol. 4, Texas Wyoming. Washington, D.C.

Watson, Irene (Fleming)

2004 Taped interview with Thad Sitton, June 15, 2004. Camp Swift Oral History Project, Center for American History, The University of Texas, Austin. 
Wharton, David G.

2000 The Soul of the Small Town: Photographs, Memories, and History From McDade, Texas. University of Oklahoma Press, Norman, Oklahoma.

Wilson, Evelyn (Cottle)

2004 Taped interview with Martha Doty Freeman, June 4, 2004. Camp Swift Oral History Project, Center for American History, The University of Texas, Austin. 


\section{INDEX}

Page numbers in italics refer to figures and tables

African Americans, 71; after Emancipation, 13, 26; and relations with rural whites, 15, 16-19, 28, 44, 46, 49-50, 55, 73, 75; communities and schools, 16-19, 38, 67, 80; farmhouses of, 26; Flowers family as farm renters, 29, 33, 38; Juneteenth celebrations of, 82-83; prices paid during the takeover for land of, 90-91; visits to town by, 76-77; work for wages, 23, 29-30

agriculture. See farming

Alexander, Amos, 11

Alum Creek, 1, 9, 13, 16, 36, 42, 58, 77, 82

archaeological research. See Camp Swift:

archaeological research on

Aussiloux, Antoine, 48

Austin, Stephen F., 7-8

automobiles, 1, 3, 3, 23, 26, 41, 42, 46, 50, 59, 60, 70, $76,75-77,79,89$

Barton, Gertrude (Dunkin), 17, 32, 33, 72

Bastrop ("Bear Strap"), 2, 3, 5, 8, 9, 10, 19, 62, 63, 77 ; as contrasted with life in the countryside, 19, 76-77; prosperity from arrival of Camp Swift, 87-89

Bastrop Advertiser, 19, 38, 61-64, 83, 91-94

Bastrop County, 1-19, 37, 42-43, 63, 64, 87-94

Bastrop School, 17, 64, 76

Bastrop State Park, 1, 59, 78, 78

beans, 33; pinto beans, 31-32, 33, 38. See also farming: subsistence; food and cooking; home garden; vegetables

beer, 26, 73. See also grapes and wine; Prohibition; whiskey

Bell, Charles, 88, 89

Bell, H. N. "Man," 15

Bell, W. J., 15

Benford, Mary Lou (Reese), 17, 26, 30, 40, 44, 47, $48,52,54-55,55,75,76,82-83$

Big Sandy Creek, 1, 2, 11, 12, 15, 16, 41, 46, 47, 48, 49, 59, 78-80

Billingsly, T. G., 64

Blackland Prairie, 3, 15, 16, 19, 29, 33, 51, 52, 53, 59, 60

blacks. See African Americans

Blackwell, Bettye. See Light, Bettye (Blackwell)

Blackwell, Ethel Kelton, 22, 23, 28, 31, 75, 77, 82

Blackwell, George, 54, 57, 74
Blackwell, Grandmother, 32, 48, 78

Blackwell, Leola. See Carman, Leola (Blackwell)

Blackwell, Willie, 22, 28, 31, 41, 44, 46-47, 48, $54-55,57,59,74,76,77-78$

Buffa, Ida Scarborough, 24

butter. See under dairy products

cabins. See homeplaces and houses; log cabins, of settlement times

Cameron, Libby Wade, 11

Camp Swift, 1, 3, 4, 5, 15, 89, 92, 87-94; archaeological research on, 3-4, 16; Bastrop County transformed by, 87-88; first settlement of area of, 11-12; land acquisitions for, 1, 3-4, 83, 87-94; origins of in World War II, 87

Camp Swift Oral History Project, 4-6

canning. See food storage and preservation, including canning

cantaloupes, 1, 26, 34, 50, 51, 53, 54. See also farming: cash crops; home gardens

Carman, Leola (Blackwell), 17, 22, 23, 44, 54, 57-58, $74,75,82$

cash crops. See farming: cash crop cash-side economy, 1, 2, 14, 15-16, 26, 29, 30, 31, 33, 34, 45, 48, 50-61, 64. See also farming: cash crop cattle, 1-2, 11, 39, 60, 63; cows, 29, 38, 39, 41, 42; free range, 15, 19, 42; milk cows, 27, 28, 31, 32, $38,40,41,64$, 78. See also dairy products; wild (Indian) cattle; work stock

Cedar Creek community, 15, 63, 71

cedar posts, 12, 51, 58-59. See also cash-side economy

cemeteries, 13, 16, 48, 61, 63, 81, 91, 92. See also

Oak Hill Cemetery Association and Picnics

Center for American History, The University of Texas at Austin, 4

Center for Archaeological Studies, Texas State University-San Marcos, 4

Chandler, S. B., 11

chickens, 1-2, 27, 29, 31, 32, 41, 42, 43, 45, 50, 51, 55, 56, 64, 73, 78, 80, 82. See also eggs; farming: subsistence; food and cooking

chores, farmstead, 5, 28-32

churches, 80-83

Civilian Conservation Corps (CCC), 59. See also

Works Progress Administration (WPA)

Clark, Edward "Tobe," 46

Colorado River, 7-11, 16, 51, 63, 79, 78-80 
Comanches, 7, 10

communal work occasions, 37-38, 43-44, 75, 81

corn, 1, 14, 19, 26, 29, 38-39, 41, 50, 52, 53, 54,

$55,62,63$; as settlement-era survival food, 7,10 ,

11-12, 15, 16; canning, 32, 37-38, 75; cornmeal,

11-12, 19, 41; feed for domestic animals, 1, 2,

$14,28,38,41-45$; fodder for work stock, 14, 28,

30, 38, 39-40; for human consumption, 15, 19,

21-22, 31, 32, 33, 38, 41-42 (see also cornbread;

cornmeal); growing and harvesting, 26, 30, 32,

34, 36, 38-41, 70. See also farming: cash crop;

farming: subsistence; food and cooking; home

gardens; vegetables

cornbread. See under food and cooking

cordwood, 16, 18, 51, 58, 59. See also cash-side economy

Cottle, Albert, 24, 27, 50

Cottle, Aubrey, 70

Cottle, Evelyn. See Wilson, Evelyn (Cottle)

Cottle, Laura (Evelyn [Cottle] Wilson's mother), 26, 38,50

cotton, 1, 3, 7, 8, 10, 13-14, 15, 16, 17, 23, 26, 29, 30, $39,47,50,51-53,54,56,60,62,63,64,70,79$. See also cash-side economy; farming: cash crop cotton gins, 13, 15, 16, 23, 29, 41, 50, 51, 52-53, 59, 61,81

courthouse town. See Bastrop

courting. See house parties

dairy products, $2,15,31$; butter, 32, 51, 59; cream, 51, 59; curds and whey, 42, 45; milk, 31, 32, 41, 42, 78. See also cattle; farming: cash crops; farming, subsistence; food and cooking

dances, country. See house parties

DeGlandon, Alcide (Grandfather), 69, 91

DeGlandon House, 22, 69

DeGlandon, Lizzy Stagner, 69

Dennison, Frank, 29, 52-53, 60-61

Depression, 5-6, 33, 42, 44, 47, 50-51, 59, 65, 79, 87

diet. See food and cooking

doctors, 47, 48, 49. See also home remedies and natural medicines

dogs, 28, 42, 44, 45, 47, 58, 77, 77-78. See also game, wild; social hunts

Dogwood Creek, 1, 2, 12, 13, 15, 16

Dogwood Creek community, 16, 61

domestic animals. See cattle; chickens; ducks; geese; guineas; hogs; turkeys; work stock

drought, 15,16

Drought of 1925, 27, 36, 61-64

drought-resistant crops, 15, 16, 63

Duck Pond community, 61

ducks, 41, 45
Dungan, Clyde, 70

Dunkin, Garland Huff (Gertrude [Dunkin] Barton's mother), 32, 33

Dunkin, Gertrude. See Barton, Gertrude (Dunkin)

Dunkin, Jess (Gertrude [Dunkin] Barton's father), 33

eggs, 2, 5, 26, 28, 31, 32, 42, 44, 45, 48, 50, 51, 56, 57, 59. See also cash-side economy; chickens; food and cooking; guineas (African peafowl); turkeys

entertainment. See family visits; fishing trips and picnics; house parties; Oak Hill Cemetery Association and Picnics; Oak Hill community: school entertainments at; radios; revivals, summer; Juneteenth celebrations; social hunts; town visits

Elgin, 1, 2, 14, 16, 17, 49, 51, 55, 59, 67, 76, 78, 83, 88,89

Elgin Courier, 83, 88, 90

Evans, Otis, 40

Evans, Sam, 26

Evans, Will, 76

family visits, 26-27, 45, 50, 57, 60, 63, 74-75, 76

farmhouses. See homeplaces and houses farming: cash crop, 1-5, 15, 29, 33, 50-58 (see also cantaloupes; cash-side economy; corn; cotton; dairy products; eggs; peanuts; pecans; sweet potatoes; turkeys; watermelons); rent, 1, 15, 24-25, 26, 29, 33, 38-39, 50, 52-53; subsistence, 1-5, $14,15-16,19,29,31,33-50,52,53,61,62-64$ (see also beans; chickens; corn; food storage and preservation; game, wild; hogs; home gardens; peas; potatoes; sweet potatoes; vegetables; work stock)

field peas. See peas

fishing trips and picnics, 63, 79, 78-80, 93, 93

Fleming, Billy, 29

Fleming, Curtis (William Curtis), 71, 77, 77

Fleming, Ella DeGlandon (Irene [Fleming] Watson's mother), 41, 44, 51

Fleming, Irene. See Watson, Irene (Fleming)

Fleming, Jerry, 29

Fleming, J. H. (Irene [Fleming] Watson's father), 68, 72

Fleming, Jimmy, 29

Fleming, Jonathan, 3, 4, 5-6, 22, 42, 71

Fleming, Russ, 50, 70

Flowers, O L, 17, 28, 29, 33, 36, 38-39, 45, 46, 52-53, $56-57,60,70-71,77,79-80,82-83$

Flowers, Pallie (O L Flowers's mother), 29, 33, 38, $45,52,57,80$

Flowers, Shirley (O L Flowers's father), 29, 52

Flowers, S T, 29, 52, 70, 77, 80 
food and cooking, 11-12, 21-22, 26, 27, 31-32, 41, 43-44, 46, 48, 63-64, 81-83; cornbread, 11, 21, 27, 31-32, 39, 41, 45, 49, 78. See also beans, chickens; corn; dairy products; eggs; meat; peanuts; peas; plants (wild), use of; potatoes; sweet potatoes; vegetables; watermelons

food storage and preservation, including canning, 33, 36-38, 39, 43-44, 46, 48, 75. See also smokehouse fox hunts. See social hunts

Fort, Clarence (Dean Fort's father), 43

Fort, Dean, 17, 26-27, 42, 43, 57, 81, 91

Fort, John W. "Doll," 26-27, 28, 58, 91

Fort, Rosabell Hibbs (Dean Fort's mother), 43

forts, log. See log forts

Freeman, Martha Doty, 5, 11, 12

free range: harvesting from the, 58-59; hogs, 19, 42-43, 54, 56; livestock on the, $3,15,19,42-45$; stock laws, 19, 42, 56; turkeys, 2, 15, 19, 53-54, $55-58$

funerals, 81. See also cemeteries; Oak Hill Cemetery Association and Picnics

game, wild: as food, 11-12, 32, 47; furs, hides, and pelts, 7, 51, 58; hunting and trapping, 7, 8, 10, 47, 58, 69, 79. See also food and cooking; social hunts; wildlife

gardens, home. See home gardens

geese, 1, 41, 45

goose pluckings. See communal work occasions

Gill's Branch, 10

Glenham community, 17

Glenham School, 17

Goerlitz, Erhard, 17, 40, 44, 47

Goerlitz, Louise (Smith), 17, 21, 47-48, 69, 68-69

Gotier Trace, 11

grapes and wine, 7, 45, 47-48, 51, 75. See also beer;

Prohibition; whiskey

guineas (African peafowl), 1, 41, 45

Hancock, Arthur (JoNell [Hancock] Majors's father), $23,23,44$

Hancock House (Arthur Hancock's house), 23, 34, 44

Hancock, JoNell. See Majors, JoNell (Hancock)

Hancock, Ruth Allen, 14

Hancock, Vivian Buffa (JoNell [Hancock] Majors's mother), 23, 24

Hardin, Annie, 19, 41, 47, 73

Harwood, Cordelia Brown, 11-12

Hoffman, Jacob, 69

hogs, 1-2 , 15, 19, 27, 29, 33, 40, 42-44, 54, 56; feed, 19, 28, 38, 41-42, 54; hog-killing, 42, 43-44, 64,

73, 75. See also farming: subsistence; food and cooking; free range: hogs; meat; smokehouse Holderman, David, 11

home gardens, 5, 26, 27, 29, 31, 34, 33-34, 35, 37, 38, 53, 62. See also beans; cantaloupes; corn; peanuts; peas; potatoes; sweet potatoes; vegetables; watermelons

homeplaces and houses, 5, 14, 21, 22, 23, 24, 25, 21-28, 34, 33-34, 53, 60, 63, 72; Camp Swift buying and destroying, 3-4, 88-91; log cabins and houses, 14, 19, 22, 23-24, 25, 36, 89, 90 (see also log cabins, of settlement times); of African Americans, 26, 90; storage at, 36, 38

home remedies and natural medicines. 48-50. See also plants (wild), use of

honey, wild, 7, 47

Hornsby, Ruben, 9

house parties, 24, 30, 72, 72-74

houses. See homeplaces and houses

hunting. See game, wild: hunting and trapping; social hunts

Jenkins, John Holland, 9, 10-11

Johnson, Lyndon Baines (LBJ), 87, 88, 91

Johnson, Ruby Mae (Thomas), 17, 49-50, 77, 90

Jones, Mr. and Mrs. Tom, 64

Juneteenth celebrations (Nineteenth of June), 82-83

Kastner, Dora Rother (Morris Kastner's mother), 29, 45,53

Kastner, Morris (Morris Kastner's father), 29

Kastner, Morris J., 5, 17, 26, 28, 29, 34, 45, 53, 75

Kesselus, Kenneth, 8

Kirby, Jack Temple, 3

Kunkle, Harry, 89

Lee, Nelson, 10

Light, Bettye Lynn (Blackwell), 21-22, 23, 28, 31, $32,41,45,47,48-49,54,55,57,69,74-75,78,82$

Lincecum, Gideon, 8

"Little Colony," establishment of, 8, 9

livestock. See cattle; hogs; work stock

$\log$ cabins, of settlement times, 9, 11, 12,-13, 14, 24, 25

$\log$ forts, 9,11

Lost Pines, 7, 16, 59

Lower Colorado River Authority, 4, 87, 88-89, 90-91

Madison, Walter, 17-18

Majors, JoNell (Hancock), 17, 23, 28, 44, 80 
McCright, Mayme (Mayme McCright Fleming), 67 McDade, 1, 2, 14, 15, 17, 23, 26, 41, 44, 45, 50, 51, 52, $53,55,59,64,67,78,79,93$

McLaughlin Creek, 1, 2, 11, 12, 15, 16, 24, 46

McLaughlin, William, 11

meat, 5, 11, 17, 32, 33, 38, 42, 43, 44, 45, 47, 48, 49,82 ; beef, $10,38,42,82,83$; lard, grease, and fat, 31, 32, 43, 48, 78; pork, 2, 31, 32, 42, 43, 44, 47; sausage, bacon, and hams, 31, 32, 43, 44, 48; squirrel and rabbit, 32, 47, 79. See also cattle; chickens; food and cooking; food storage and preservation; game, wild; hogs

medical care. See home remedies and natural medicines

Mexicans, 53, 60, 60-61

milk. See under dairy products

Miller, Jephty (May Belle [Miller] Morriss's father), $31,35,73$

Miller, Jepp Hill, 74

Miller, May Belle. See Morriss, May Belle (Miller)

Miller, Sally Benight (May Belle [Miller] Morriss's mother), 31

Mills, Perry, 76

Morgan, Jackson, 26, 90

Morriss, May Belle (Miller), 17, 31-32, 35, 45, 50, 59, 68, 69, 73-74, 81

Municipality of Mina, 8,9

music and singing, 22, 30, 63, 64, 71, 72, 73-74, 75, 76

musicians, 73-74. See also house parties

Native Americans, 7-12; in conflict with Anglo settlers, 8-11. See also Comanches

natural medicines. See home remedies and natural medicines

newspapers. See Bastrop Advertiser; Elgin Courier

Nineteenth of June celebrations. See Juneteenth celebrations.

Oak Hill Cemetery Association and Picnics, 61, 62, $63,82,81-83,91$

Oak Hill community, 1, 2, 13, 14, 17, 19, 42, 58, 76, 89-94; during Drought of 1925, 61-64; farmhouses at, 13, 14, 21, 22, 23, 24, 25, 21-26, $28,33,44,60,61,89$; last days chronicled by Polly Owen in Bastrop Advertiser, 91-94; population increase after Civil War, 15-16; school entertainments at, 64-67, 71-72, 81, 91; settlement of, 14, 13-15, 42; union church at, 13, 16, 61, 62, $80-81,93$

Oak Hill School, 13, 16, 17, 18, 61, 65, 66, 68, 70, 62-72, 93
Old San Antonio Road (El Camino Real), 1, 7

orchards, 34, 34, 35, 47, 53, 88, 92

Owen, Andrew, 14, 30, 70

Owen, Bill, 55

Owen, Edgar, 37, 61, 72, 92, 93

Owen, Elgitha "Githa” Smith (Fay [Owen] Pannell's mother), 17, 21, 30, 31, 33, 60, 63, 71, 72

Owen, Fay. See Pannell, Fay (Owen)

Owen House (Joe Owen's house), 21

Owen House (T. W. Owen's house), 14, 61

Owen, Jack, 77

Owen, J. D. "Joe" (Fay [Owen] Pannell's father), 3 , 17, 21, 59, 59-61

Owen, Polly (Mrs. Edgar Owen), 33, 37, 38, 43, 61, 61-64, 71, 72, 80, 91-94

Owen, Robert, 70

Owen, T. W., 14, 55, 61

Page, Pat, 87

Pannell, Fay (Owen), 17, 21, 30, 31, 32, 33, 35, 37, 41, 59-61, 68, 72, 73, 76, 77, 78, 80, 89-90, 94

Pannell, Peggy, 90

peanuts, $1,15,29,31,32,34,38,39,41,46,50,51$,

53, 67,69

peas: field (cowpeas), 1, 10, 29, 31, 32, 34, 36-37, 38,

41, 45; black-eyed, 32, 33, 36; English, 33

pecans, $2,7,45,47,51,57,59$

peddlers, 75

Perkins, Jim, 18

Phelan community, 17

picnics. See fishing trips and picnics; Oak Hill

Cemetery Association and Picnics

Piney Creek, 1, 2, 11, 12, 13, 15, 16, 48, 68, 76

Piney Creek community, 12, 15, 16, 61, 80, 81, 82, 83

Piney Creek School, 16, 67

pinto beans. See beans

plants (wild), use of, 19, 47-49. See also home

remedies and natural medicines

population, county, $15,97-88$

potatoes, 64; Irish, 33, 34, 35. See also home gardens; sweet potatoes

Powell, Mr. (Oak Hill schoolteacher), 68, 70

Prohibition, 26, 48. See also beer; grapes and wine; whiskey

public work, 51, 59-61

Puesta del Colorado, 7-8

quilts and quiltings, 21, 22-23, 38, 75, 82

radios, $74,75-76$

railroads, 14, 15, 16, 18, 55, 60, 61, 87 
Ransom House (John Ransom House), 24, 23-24, 25, 89,89

Ransom, John, 24

Reconstruction, 15

recreation. See family visits; fishing trips and picnics; house parties; Oak Hill Cemetery Association and Picnics; Oak Hill community: school entertainments at; radios; revivals, summer; Juneteenth celebrations; social hunts; town visits Reese, Dovie, 40

Reese, Isom (Mary Lou [Reese] Benford's father), 30, 40, 54-55

Reese, Mary Lou. See Benford, Mary Lou (Reese)

Reese, Viola (Mary Lou [Reese] Benford's mother), 44,56

revivals, summer, $16,80,81$

roads, highways, and travel, 1, 2, 4, 7, 8, 10, 11, 16, $26,28,36,42,46,47,49,52,55,57,59,64,67,68$, 69, 75-77, 79-80, 83, 87, 88, 91, 92

Robinson, David G., 88-89, 90

sand hills, 16, 42, 58, 77, 91

Sandy Creek. See Big Sandy Creek

San Felipe, 7, 11

Sayers(ville) Coal Mine, 60, 60-61

Sayers(ville) Coal Mine Commissary, 53, 61, 61

Sayers(ville) community, 1, 2, 15, 16, 17, 17-18, 19, $29,33,38,52,53,60,61,67,73,76,79,80,81$, $82-83$

Sayers(ville) School, 16, 17, 67, 70, 71, 72

Sayers Store, 17, 18, 59, 60

schools, rural, 16, 17, 51, 52, 64-72, 88; discipline at, 70-71; entertainment at, 64-67, 71-72, 81, 91; sports at, 71, 71-72; students travel to and from, 69-70, 76. See also Bastrop School; Oak Hill School; Piney Creek School; Sayers(ville) School; Wayside School

Scott, Abner, 12

Scott, Abner C., 13, 17, 22, 24, 29, 37, 38, 46, 47, 49, $58,62,67,69-70,78,79,81,90$

Scott, Allen, 13

Scott, Dan, 13, 22, 49, 70, 90

Scott, Donald, 13

Scott Falls community. See Spring Branch community

Scott, Grover (Abner C. Scott's father), 12, 13, 29, 36, $37,40,47,49,59,70,78,90$

Scott, Harlan, 13

Scott House (Abner Scott's house), 25,

Scott, Ina Fay (Abner C. Scott's mother), 12, 13, 29, 37, 51-52, 81

Scott, Jesse Lee, 13, 25, 54

Scott, John, 28, 44, 62, 67, 69
Scott, Louisa, 12

Scott, Mary Lou, 13, 54

Scott, Minnie Lea (Mrs. John Scott), 38, 44, 54, 63

Scott, Oleta, 67

Scott, S. J. “Jack," 17, 28, 33, 44, 51-52, 76

Sharpless, Rebecca, 31

Shelton, Ezra, 3

Shelton, Jesse, 3

Shelton, Mrs. Minnie, 63, 72

Smith, Amy, 27, 78

Smith, Andrew Morgan, 39, 79

Smith, Bertie Hancock (Ruth E. Smith's mother), 27, 53,82

Smith, Bonnie, 27

Smith, Edith Mae, 35

Smith, Gertrude, 27

Smith, Grace DeGlandon (Louise [Smith] Goerlitz's mother), 22, 56

Smith, Harvey (Louise [Smith] Goerlitz's father), 21, 22, 89, 93

Smith House (Harvey Smith House), 23

Smith, Kenneth, 27

Smith, Louise. See Goerlitz, Louise (Smith)

Smith, Pansy, 72

Smith, Robert (Ruth E. Smith's father), 27, 53, 53, 55, 63

Smith, Ruth E., 17, 27, 27, 53, 55, 63, 73, 75, 78, 82

Smith, Sue, 35, 39

Smith, Thurber, 71

Smith, Violet, 71

Smith, Woodrow, 27

Smithwick, Noah, 9, 10

smokehouse, 2, 5, 31, 38, 42, 43-44. See also food preservation and storage; hogs; meat social hunts, 77, 77-78. See also game, wild soils, 1, 8, 15, 16, 19, 23, 26, 34, 36-37, 44, 48, 51, 54, $59,62,63$

Southern agriculture, diversity of, 3. See also farming

Spring Branch community (Scott Falls community), $1,2,4,13,16,17,17,26,61$

Stagner, Hollis, 14

Stagner, Joyce, 72

Stagner, Lizzy, 69

Stagner, Mrs. J. O., 72

Stagner, Thurston, 14

Stewart, Minerva, 75

stock, work. See work stock

stores, 2, 13, 17, 18, 32, 45, 47, 53, 58, 60, 61, 88, 92

Strong, Arthur, 74

Strong, John Arthur, 74-75

subsistence crops. See farming: subsistence

Sunday dinner, 45, 80

sweet potatoes, $1,15,26,29,31,32,33,34,35-36$, 
sweet potatoes (continued), 37, 41, 46, 47, 50, 51, 53, 59. See also home gardens; potatoes syrup, cane, and syrup making, 29, 31, 32, 45-47, 51

Taylor, Green, 28, 46

Texas Agricultural Extension Service, 37-39, 62-63

Texas Army National Guard, 3, 4

Texas Parks and Wildlife Department, 4

Thomas, Isiah (Ruby Mae and Walter Thomas's father), 90

Thomas, Lula (Ruby Mae and Walter Thomas's mother), 17, 26, 49, 90

Thomas, Ruby Mae. See Johnson, Ruby Mae (Thomas)

Thomas, Walter, 17, 17, 26, 49-50, 73, 77, 90-91

Thompson, Cal, 15

town visits, 76-77

travel. See roads, highways, and travel

truck crops. See cantaloupes; corn; cotton; peanuts; sweet potatoes; turkeys; watermelons

turkeys, 1-2, 7, 8, 11, 15, 19, 29, 41, 42, 45, 47, 50, 51, $53,56,58,55-58,64$

United States Army, 1, 3-4, 87-93

vegetables, 1, 5, 17, 31, 33-37, 38, 82, 92. See also beans; corn; home garden; potatoes; sweet potatoes; peas

vegetation, $1,55-56$

watermelons, 1, 10, 26, 29, 34, 35, 37, 50, 51, 54, 55, $53-55,56,57,59,62,63$

water sources, farmstead and livestock, 2, 4, 5, 13, 16, 17, 19, 27-28, 47, 49, 63, 67. See also Alum Creek; Big Sandy Creek; Dogwood Creek; McLaughlin Creek; Piney Creek

Watson, Irene (Fleming), 17, 21, 23, 41, 44, 50, 51, 59, $62,68,70,72,81,82,90$

Wayside community, 1, 2, 15, 16, 17, 19, 61, 63, 72

Wayside School, 15, 17, 67, 67, 69-70

whiskey, 49, 73. See also beer; grapes and wine; Prohibition

wild (Indian) cattle, 7, 8, 12

Wilbarger, Joseph, 10

wildlife, 7, 8, 12, 45, 47, 69. See also game, wild; social hunts

Wilson, Evelyn (Cottle), 17, 24-25, 27, 38, 50, 59, 72-73, 90

wine. See grapes and wine

work for wages. See public work

Works Progress Administration (WPA), 59. See also

Civilian Conservation Corps (CCC)

work stock, 14, 19, 26, 28, 40-41, 42, 49, 53, 64, 83, 88; horses, 10, 12, 19, 28, 29, 41, 42, 70, 75, 92; mules, 5, 13, 19, 28, 32, 36, 39, 40, 40-41, 42, 46, $52,54,70$; oxen, 19, 36, 42, 83. See also farming 
